\title{
Three Essays on How Migrant Remittances Respond to Natural Disasters in their Home Countries
}

\author{
by
}

Priyanka Debnath

A thesis submitted to the Faculty of Graduate and Postdoctoral Affairs in partial fulfillment of the requirements for the degree of

Doctor of Philosophy

in

International Affairs

Carleton University

Ottawa, Ontario

(C) 2017, Priyanka Debnath 


\begin{abstract}
The home countries of many migrants frequently suffer from both low income and an exposure to natural disasters. Disasters are particularly devastating for lower income families, and can adversely affect their incomes and well-being. The New Economics of Labour Migration theory suggests that migration and the resulting remittances can be a critical risk-mitigation strategy adopted by households in the face of natural disasters. This thesis explores the extent to which remittances are sensitive to natural disasters in the migrant's home country. Three separate chapters use different datasets to examine this main research question. The key finding of all three chapters is unequivocal: remittance inflows are consistently and positively related to the presence of natural disasters in the home country.
\end{abstract}

Chapter 2 uses large-scale data on recent Canadian immigrants and finds compelling evidence that they remit significantly more in the aftermath of natural disasters affecting their home countries. In addition to examining other personal and family characteristics associated with remitting behaviour, the study found that the administrative category under which they entered Canada also influenced their remitting patterns.

Chapter 3 examines a unique dataset based on primary data collected through 118 in-depth interviews from two migration-prone villages in Bangladesh. It explores how migrants and their families use migration and remittances as a coping mechanism in the face of frequent flooding. The role of gender appears as particularly important. While men tend to send more money home, they also tend to earn more as migrants. By contrast women remit a larger share of their income generally, and send almost all their residual income in the event of a natural disaster. 
Finally, using aggregate monthly remittances, Chapter 4 examines the responsiveness of remittances into Pakistan in the aftermath of natural disasters. The response is significant, with total remittances increasing on average more than US\$9,666 per fatality. Few other factors were also analyzed to investigate their influence on remittances. While religious festivities are associated with higher remittances, remittance inflows appear largely non-responsive to terrorist events in the country, with weak evidence that remittances are actually deterred in the aftermath of these events. 


\section{Acknowledgements}

There are not enough words to convey my gratitude and respect for my thesis supervisor, Dr. Dane Rowlands. This PhD would not have been possible without his encouragement, mentorship and guidance. He has inspired me to become a better researcher and helped me realize the power of critical thinking, hard work and commitment.

I would also like to express sincere thanks to my Thesis Advisors and the Examination Committee - Dr. Yiagadeesen (Teddy) Samy, Dr. Ravi Pendakur, Dr. Anupam Das and Dr. Howard Duncan - for their invaluable comments and guidance. I am also grateful for the guidance that I have received from Dr. Binyam Solomon.

My experience at NPSIA would not have been the same without the support and encouragement of the broader NPSIA family particularly Patricia Lacroix and Norean Shepherd.

There are a few other people to whom I owe heartfelt thanks for helping me stay sane during my doctoral degree. I am most grateful to my friends Patricia Alcalde, Diego Cezer, Margaret and Henry Jacques, for cheering me on, for always adding laughter to my life and for their hospitality. During my PhD journey, I have also met several friends and loved ones - Scott Fairweather, Jeanne Arbez, Jasmine Gujral, Andrea Roberts, Andrea Nemeth - whose thoughts and comments on my various chapters have enriched this thesis.

The choice of my dissertation topic is deeply rooted in my passion for working for migrants' issues and understanding their stories. Being a first-generation immigrant, I feel humbled to have had this opportunity to contribute to the literature of migration, natural disasters and remittance studies. 
To my parents, my grandmothers and my aunt - I am indebted to you for all your love and blessings. My sincere gratitude for your endless support and patience. It is not easy to be a parent, a grandparent or an aunt to a Doctoral Student! You have done so always with a smile.

Finally, I dedicate this thesis to my mother, Rina Sen Gupta, for her unconditional love. It is her love and faith in me that raised me up when I got weary. Being a migration policy expert herself, my successful completion of this degree will make her the happiest in the world! 


\section{Table of Contents}

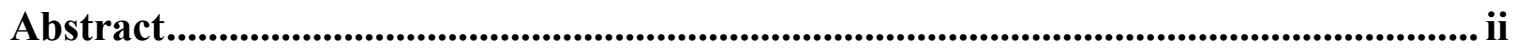

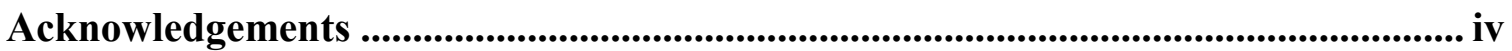

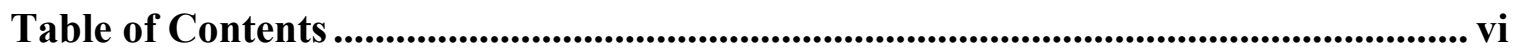

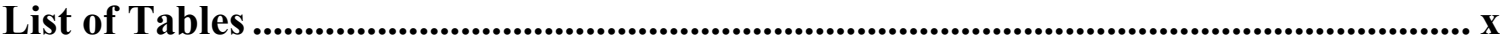

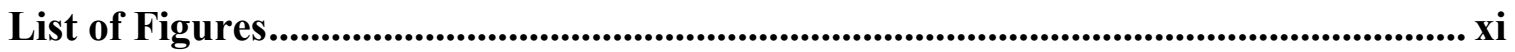

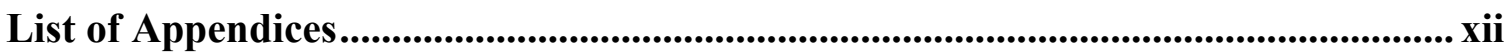

Chapter 1: Introduction ........................................................................................... 13

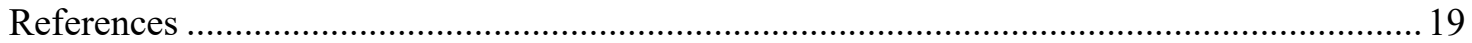

Chapter 2: What Are the Impacts of Natural Disasters on the Remitting Patterns of Recent Canadian Immigrants? ............................................................................ 22

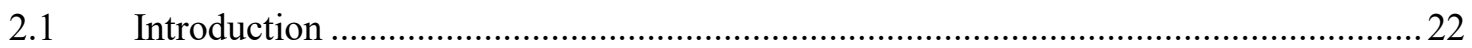

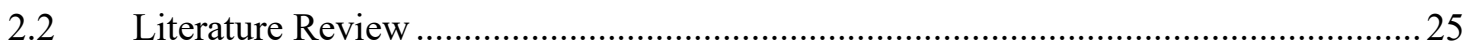

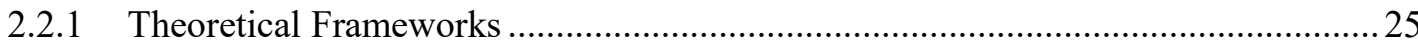

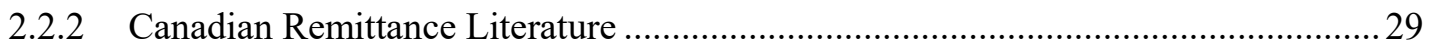

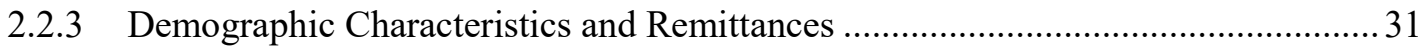

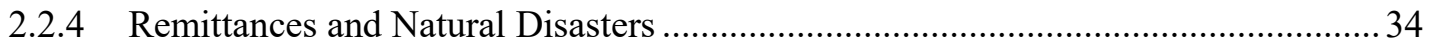

2.3 Methodology: Data, Sample Construction and Estimating Procedure …..................... 35

2.3.1 Longitudinal Survey of Immigrants to Canada (LSIC) ........................................... 36

2.3.2 Center for Research on the Epidemiology of Diseases (CRED), International

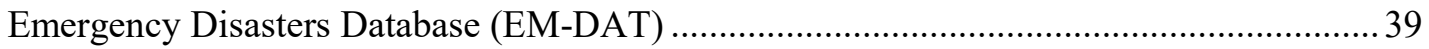

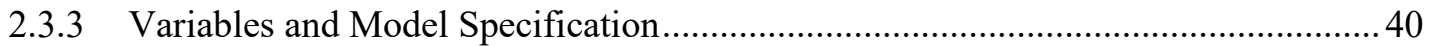

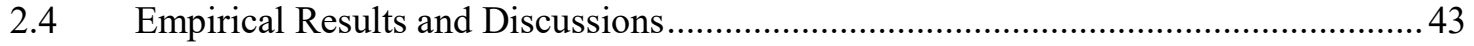

2.4.1 Remittances Increase in Response to Natural Disasters ......................................... 43 
2.4.2 Effects of Immigrants' Household and Personal Characteristics on Remittances Sent

2.4.3 Effect of Immigration Category and Province of Residence on Remitting Patterns 55

2.4.4 Effect of Ties with Home Country and Host Country (Canada) on Remitting Patterns .58

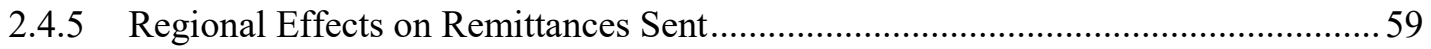

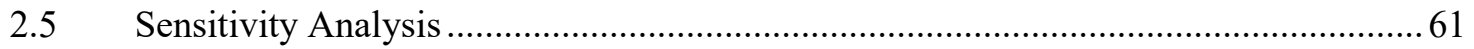

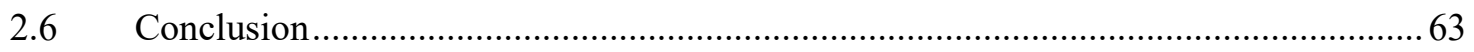

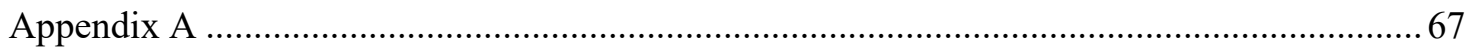

A.1 Details of Disasters included under each Threshold for Wave 2 and Wave 3..........67

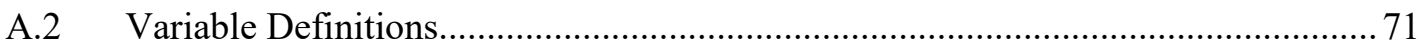

A.3 Tobit Estimations for Monthly Remittance Levels (T-statistics in brackets below the

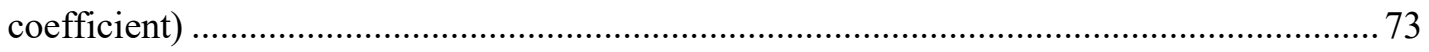

A.4 Tobit Estimations for Monthly Remittance Levels (T-statistics in brackets below the

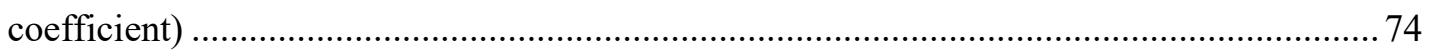

A.5 Tobit Estimations for Monthly Remittance Levels for Single Adult Households Only (T-statistics in brackets below the coefficient)............................................................... 75

A.6 Tobit Estimations for Monthly Remittance Levels for Principal + Spouse Respondents

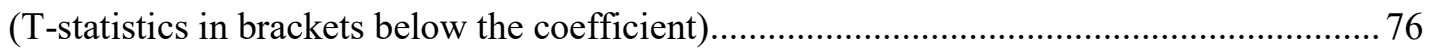

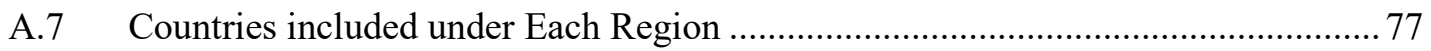

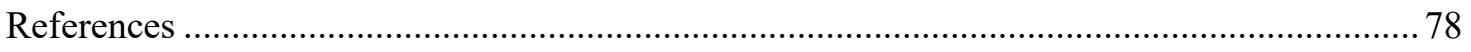

Chapter 3: Climate Change Induced Migration and Post Disaster Remittance Responses through a Gender Lens ...................................................................................... 87

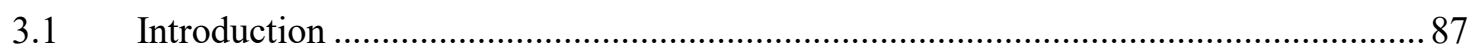

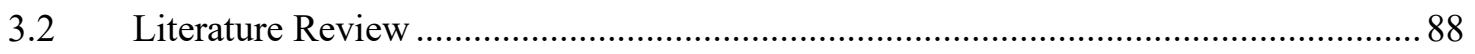


3.3 Data: Methodology, Description of the Study Site and the Characteristics of the

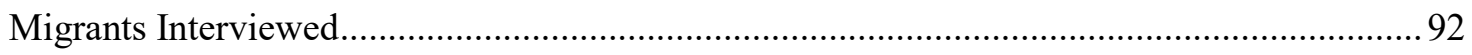

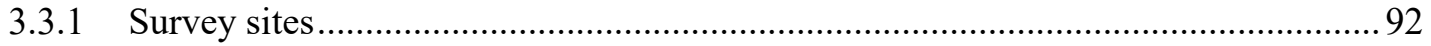

3.3.1.1 Rationale Behind Choosing the Survey Sites ................................................ 92

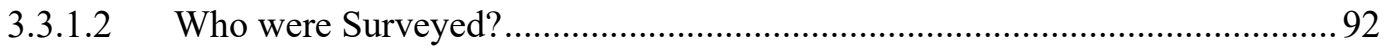

3.3.2 Profile of the Study Population and their Migration Experiences ........................... 96

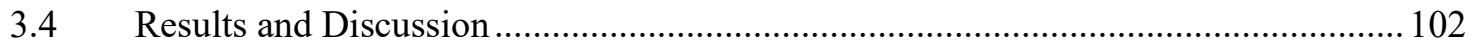

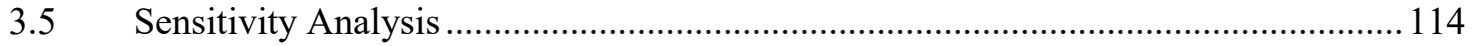

3.5.1 Parsimonious Model vs. Full Model ..................................................................... 114

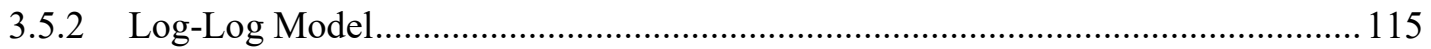

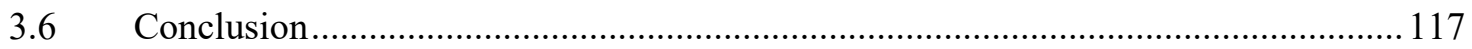

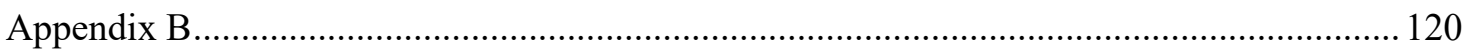

B.1 Summary Statistics of Migrants in Village A and Village B ............................... 120

B.2 Regression Results when the Parsimonious Model is Separately Ran for All Male

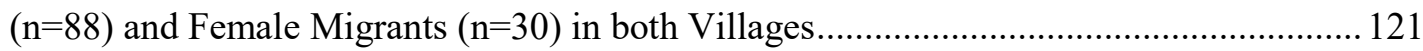

B.3 Regression Results for Village A and Village B .............................................. 122

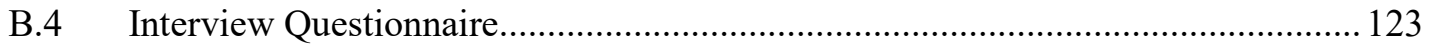

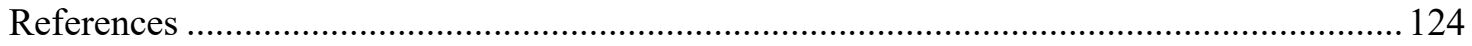

\section{Chapter 4: Impact of Natural Disasters on Aggregate Remittances Inflows: The Case}

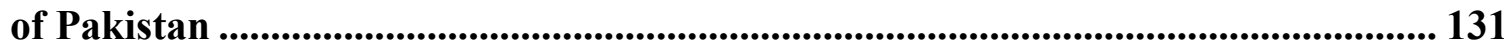

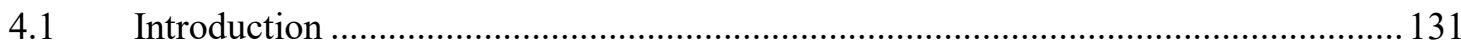

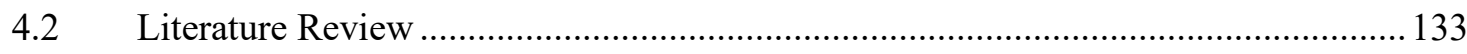

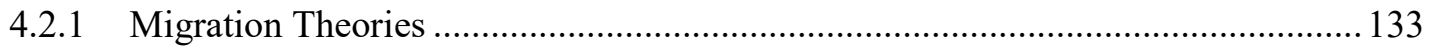

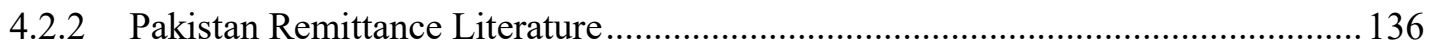

4.2.3 Remittances and Natural Disasters in Pakistan.................................................... 137

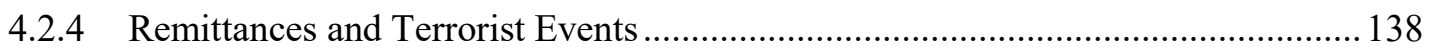


4.2.5 Remittances and Major Religious Events in Pakistan 139

4.3 Methodology: Data Sources, Sample Construction and Estimating Procedure. 140

4.3.1 State Bank of Pakistan's Workers' Remittance Database 140

4.3.2 Disaster Data from the Center for Research on the Epidemiology of Diseases (CRED), International Emergency Disasters Database (EM-DAT) .................................................... 146

4.3.3 Terrorism Data from the Global Terrorism Database (GTD) .............................. 149

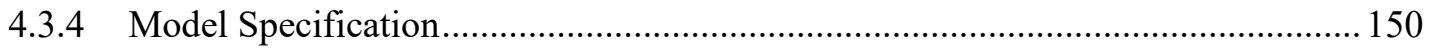

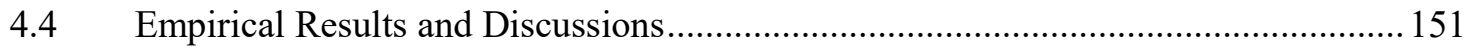

4.4.1 Remittance Inflows Increase in the Aftermath of Natural Disasters ..................... 152

4.4.2 Responsiveness of Remittances to Terrorism-related Fatalities in Pakistan............ 154

4.4.3 Responsiveness of Remittances to Major Religious Events in Pakistan ................ 155

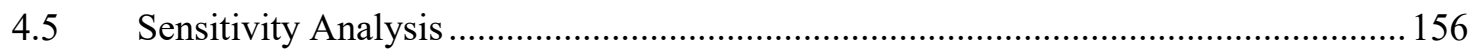

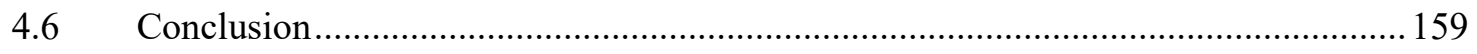

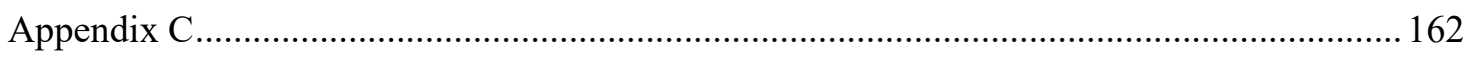

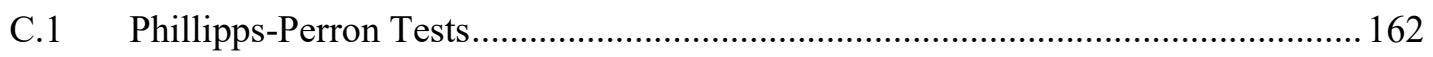

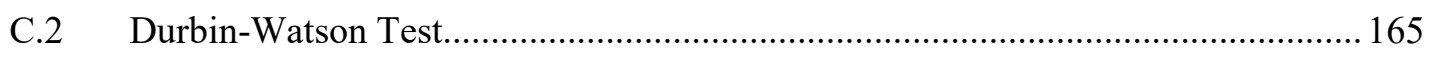

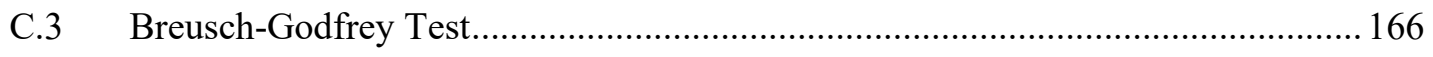

C.4 ARDL Models Using Error-Correction ............................................................. 167

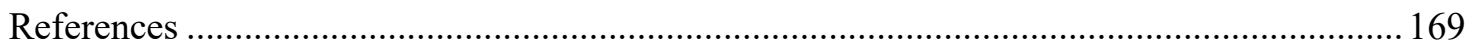

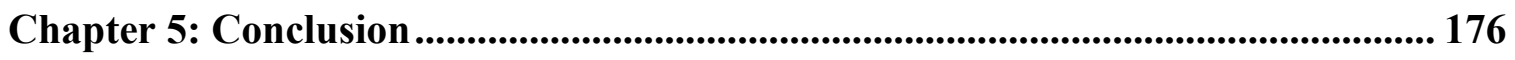

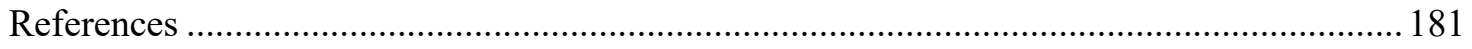




\section{List of Tables}

Table 2.1: Weighted Sample Means of Migrant Characteristics in Waves 2 and 3 ........ 41 Table 2.2: Tobit Estimations for Monthly Remittance Levels (T-statistics are in brackets

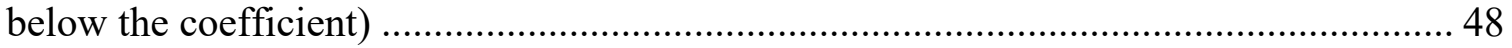

Table 3.1: Share of Female and Male Migrants in Villages A and B ............................ 96

Table 3.2: Number of Temporary and Permanent Migrants Originating from Villages A and $\mathrm{B}$ 97

Table 3.3: Regression Results for all Migrants in both Villages $(n=118)$ 105

Table 3.4: Log-log Model - Regression Results for all Migrants in both Villages $(n=118)$

Table 4.1: Main Estimation Results 152

Table 4.2: ARDL Estimation Results 157 


\section{List of Figures}

Figure 2.1: Remittance Inflows and other External Financial Inflows to Developing

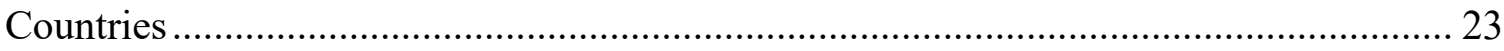

Figure 3.1: Destination Cities within India where 118 Migrants Work ........................... 97

Figure 3.2: All Female Migrants' Marital Status and Age Profile .................................... 98

Figure 3.3: All Male Migrants' Marital Status and Age Profile ....................................... 98

Figure 4.1 Various Development Finance Inflows to Pakistan (1996-2010) ................. 132

Figure 4.2 Remittances by Host Countries (1996-2010) ............................................. 141

Figure 4.3: Total Remittances Inflows to Pakistan ........................................................ 142

Figure 4.4: Remittances to Pakistan from Saudi Arabia.............................................. 142

Figure 4.5: Remittances to Pakistan from Canada ............................................................ 143

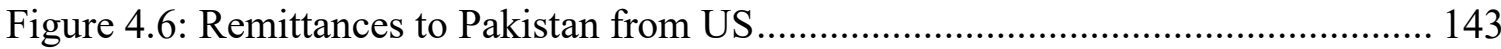

Figure 4.7: Remittances to Pakistan from the UK ....................................................... 144

Figure 4.8: Remittances to Pakistan from EU (excl. UK) ............................................. 144

Figure 4.9: Remittances to Pakistan from UAE........................................................... 145

Figure 4.10: Remittances to Pakistan from other GCC Countries (excl. Saudi Arabia and

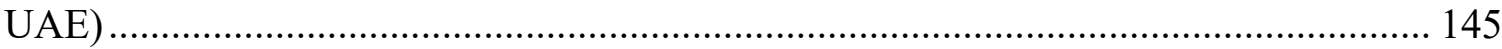

Figure 4.11: Terrorism-related Fatalities (1996-2010) .................................................. 150 


\section{List of Appendices}

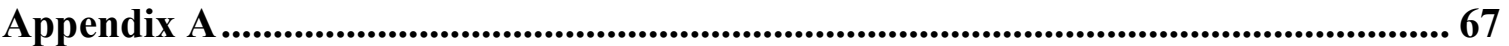

A.1 Details of Disasters included under each Threshold for Wave 2 and Wave 3.............67

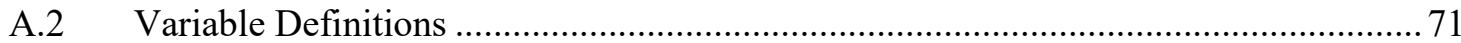

A.3 Tobit Estimations for Monthly Remittance Levels (T-statistics in brackets below the

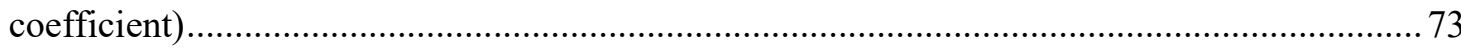

A.4 Tobit Estimations for Monthly Remittance Levels (T-statistics in brackets below the

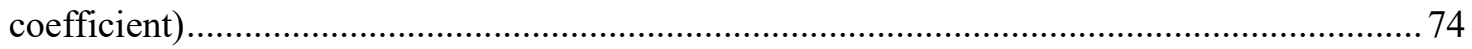

A.5 Tobit Estimations for Monthly Remittance Levels for Single Adult Households Only

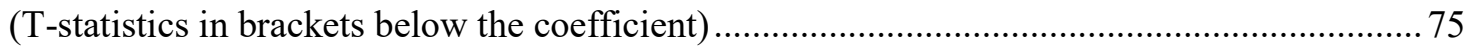

A.6 Tobit Estimations for Monthly Remittance Levels for Principal + Spouse Respondents

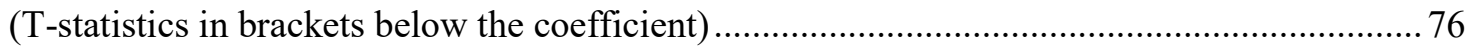

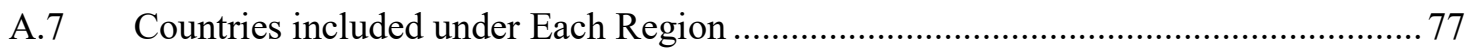

Appendix B .............................................................................................................. 120

B.1 Summary Statistics of Migrants in Village A and Village B.................................. 120

B.2 Regression Results when the Parsimonious Model is Separately Ran for All Male ( $\mathrm{n}=88)$

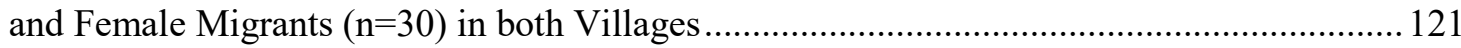

B.3 Regression Results for Village A and Village B .................................................... 122

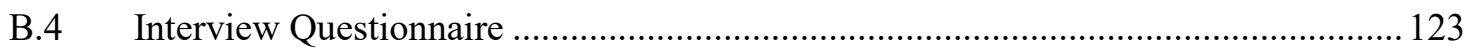

Appendix C .......................................................................................................................... 162

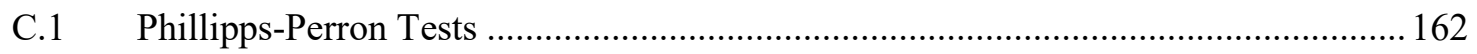

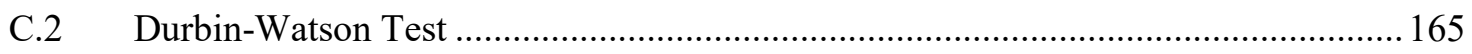

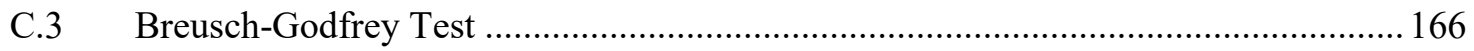

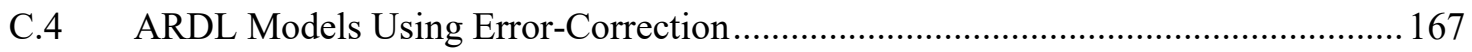




\section{Chapter 1: Introduction}

Climate change, on its own, does not directly displace people or cause them to move (International Organization for Migration [IOM], 2015). However, an important manifestation of climate change is the rise in the incidence of extreme weather-related natural disasters. These natural disasters intensify the current vulnerabilities that make it difficult for people to survive where they are (IOM, 2015). Consequently, migration, whether temporary or permanent, is becoming an increasingly common survival strategy adopted by people confronting natural disasters (Hugo, 1996).

The movement of people as a result of changes in their environment is not a new phenomenon. Despite the linkages between weather-related events and migration, examination of this relationship has been largely ignored until recently due to a lack of consensus among scholars and policy makers about the interconnectedness of these two issues (IOM, 2009). Furthermore, historically the bulk of migration caused by environmental change has occurred within national boundaries, resulting in internal migration or displacement (Hugo, 1996). The international dimension of this relationship - that is, movement of people outside national boundaries as a response to environmental events - is also a relatively new research area.

Despite the lack of precise figures, there is now little doubt that parts of the earth

are becoming less habitable due to factors such as climate change, deterioration of agricultural lands, desertification, and water pollution (IOM, 2015). The incidence as well as the intensity of natural disasters has been on the rise (Nuade, 2010). The number of natural disasters has more than doubled over the last two decades. In 2008 alone more than 20 million people were displaced by sudden climate-related natural disasters (OCHAIDMC, 2009). Data from the Centre for Research on the Epidemiology of Disasters shows 
that South Asia and Sub-Saharan Africa recorded the largest number of people affected by natural disasters between 1974 to 2003 (Nuade, 2010). Natural disasters are shown to permanently and negatively affect growth in developing countries by pushing households into poverty traps (Carter, Little, Mogues, \& Negatu, 2007). Estimates have suggested that between 25 million to one billion people could be displaced by climate change over the next 40 years (IOM, 2015).

Within the countries, the effects of natural disasters are also distributed unequally. While natural disasters increase the risks faced by all households, they are particularly devastating for lower income families, and can create serious risks for their incomes and well-being. The International Organization for Migration (IOM, 2008) reports that all regions of the world are likely to experience some adverse effects of climate change, but less developed regions are especially vulnerable because a large share of their economies depend on environment-sensitive sectors and their adaptive capacity is low due to low levels of human, financial and natural resources, as well as limited institutional and technological capability (IOM, 2008). Another distributional dimension of disasters is that they are not gender-neutral. Natural disasters affect women and men differently and their responses to the effects of natural disasters are also different owing to their distinct roles and access to resources in the society they live.

The conceptualization of migration as an adaptive response to household financial stress has been explored in the theory of New Economics of Labour Migration (NELM) (Stark \& Bloom, 1985). NELM theory suggests that a commonly adopted environment risk-mitigation strategy by households is to engage in labour migration as a means to diversify household income sources (Stark \& Bloom, 1985; Katz \& Stark, 1986). Households use income diversification strategies as a hedge against potential negative 
outcomes including a lost or devalued harvest or an injured family member (Davis \& Lopez-Carr, 2014). Migration is viewed as an investment and remittances are labelled as a return on that investment. Migrants send remittances to secure and smooth their families' consumption levels in a context of missing or imperfect financial and insurance markets (Gubert, 2002). The prospect of receiving remittances "is often a key element in the motivation to migrate in the first place" (Carling, 2008, p. 582).

Natural disasters are an important driver for migration and remittances are critical in dealing with their adverse effects (Mbaye \& Zimmerman, 2016; Fagen, 2006). The overarching theoretical framework and motivation of this dissertation is rooted in the NELM approach that supports that remittances help reduce households' vulnerability to shocks (such as those from natural disasters) and at the same time it also dampens their adverse effects (Mbaye \& Zimmerman, 2016). It is important to note that while NELM provides a theoretical framework, it does not identify specific variables that would need to be analyzed to capture its application. The role of individual or family characteristics in determining specific migration or remittance behavior is likely to be specific to context and culture. What NELM provides instead is an overarching framework that views remittance earning as a separate source of income that a household can rely on to reduce the adverse impacts from unfavourable shocks. Using three separate essays this dissertation tests the extent to which NELM theoretical assertions hold true.

There is a strong consensus in literature that remittances have become a relatively reliable, stable and growing source of development finance for many developing countries (IOM, 2015). In 2015, there were about 232 million international migrants in the world, of which roughly 50 per cent reside in ten highly urbanized, high-income countries (IOM, 2015). The remittances that these migrants send to their countries of origin are an 
influential source of international financial flow. Migrants' remittances to developing countries reached approximately US $\$ 441$ billion in 2015 , which is about three times the size of official development assistance and even greater than foreign direct investment inflows, excluding China (The World Bank, 2016). Furthermore, a review of the current literature suggests that remittance inflows increase or remain relatively stable after the onset of large shocks, such as, natural disasters, macroeconomic or financial crises and armed conflicts (Clarke \& Wallsten, 2004; Mohapatra, Joseph, \& Ratha, 2012; Weiss Fagen \& Bump, 2006; The World Bank, 2006).

Using three separate essays, each informed by distinct datasets analyzing different countries, this dissertation investigates the overarching research question, "Do migrants remit more in the aftermath of natural disasters affecting their countries of origin?" Each essay (presented as a separate chapter) also identifies several other related hypotheses that reflect the dataset and the country being examined.

Utilizing large sample data from Statistics Canada's Longitudinal Survey of Immigrants to Canada (LSIC) as well as the disaster data from the International Emergency Disasters Database (EM-DAT), Chapter 2 (the first essay) investigates the responsiveness of remittances sent by recent Canadian immigrants in the aftermath of natural disasters in their countries of origin. This chapter also investigates the role of other micro-level determinants of remittances such as the migrant's age, sex, marital status, education levels, and membership in community organizations.

This chapter makes a unique contribution to the existing literature in two major ways. First, at the Canadian national level, there is a lack of in-depth research on Canadian immigrants and their remitting behaviour. To date, the examination of remittance data for Canadian immigrants has been conducted largely without reference to events and 
conditions in their countries of origin. Second, at the international level, there are also only a handful of micro level empirical studies that examine the relationship of remittances in the aftermath of natural disasters. Most of these studies examine the relationship using one country of origin; however, given that the LSIC database contains immigrants originating from various regions of the world, this chapter examines this relationship for many regions.

Chapter 3 uses a unique dataset based on primary data collected through 118 indepth field interviews with migrants from two migration-prone villages in Bangladesh located near the southwest border to India. These data are used to investigate the responsiveness of remittances sent by these migrants in the aftermath of natural disasters affecting their home communities. Along with answering the main research question of this dissertation, this chapter applies a gender lens in understanding how the culturallydetermined roles of women in these traditional and patriarchal communities shape their migration decisions as well as their remitting patterns in post disaster situations.

Although a few recent studies on Bangladesh have focused on examining the effect of climate change on people's decision to migrate (IOM, 2009), there is a significant gap in the literature when it comes to exploring the responsiveness of remittances sent by Bangladeshi migrants in the aftermath of natural disasters. This gap is further pronounced when understanding how existing gender relations within society shape the way female and male migrants remit and how each of these groups respond in the aftermath of a disaster affecting their households. Chapter 3 contributes to the existing literature by addressing these gaps.

Using monthly remittance data from the State Bank of Pakistan and natural disaster data from the International Emergency Disasters Database (EM-DAT) for the periods 1996-2010 and 2002-2010, Chapter 4 examines the behaviour of aggregate remittance 
inflows into Pakistan in response to natural disasters affecting Pakistan. This paper also estimates the role of other important country specific determinants such as major religious events and terrorism-related fatalities on remitting patterns.

Although there are a few recent studies on Pakistan that have focused on understanding the linkages between remittances and poverty and remittances and terrorism, there are no country level studies that analyzes the linkages between remittance inflows and natural disasters. This chapter makes a significant contribution to the literature by addressing this gap.

Despite the different datasets, levels of analysis, countries and time periods, all three essays find strong and robust evidence of a significant increase in remittances in response to natural disasters in the home community. These results are consistent with the NELM framework, and indeed arguably provides compelling evidence of the important risk mitigation role of migration and the associated remittances that NELM predicts. Natural disasters can be one of the most extreme sources of risk faced by many vulnerable households, and the compensatory response of remittances is an important mechanism for disaster relief. 


\section{References}

Carling, J. (2008). The determinants of Migrant Remittances. Oxford Review of Economic Policy, 3(1), 582-599. doi: https://doi.org/10.1093/oxrep/grn022

Carter, M., Little, P., Mogues, T. \& Negatu, W. (2007). Poverty traps and natural disasters in Ethiopia and Honduras. World Development, 35(5), 835-856. Retrieved from https://doi.org/10.1016/j.worlddev.2006.09.010

Clarke, G. \& Wallsten, S. (2004). Do Remittances Protect Households in Developing Countries Against Shocks? Evidence from a Natural Disaster in Jamaica. Washington, DC: Mimeo.

Davis, J., \& Lopez-Carr, D. (2014). Migration, remittances and smallholder decisionmaking: implications for land use and livelihood change in Central America. Land Use Policy, 38, http://doi.org/10.1016/j.landusepol.2013.09.001

Fagen, P. W. (2006). Remittances in conflict and crises: How remittances sustain livelihoods in war, crises and transitions to peace. Policy Paper International Peace Academy.

Gubert, F. (2002). Do migrants insure those who stay behind? Evidence from the Kayes Area (Western Mali). Oxford Development Studies, 30(2), 267-287. http://dx.doi.org/10.1080/1360081022000012699

Hugo, G. (1996). Environmental Concerns and International Migration. The international Migration Review, 30(1), 105-131. doi: 10.2307/2547462

International Organization for Migration [IOM]. (2008). World Migration 2008:

Managing Labour Mobility in the Evolving Economy. Retrieved from https://publications.iom.int/system/files/pdf/wmr_1.pdf 
International Organization for Migration [IOM]. (2009). Migration, Environment and Climate Change: Assessing the Evidence. Retrieved from http://publications.iom.int/system/files/pdf/migration_and_environment.pdf International Organization for Migration [IOM]. (2015). World Migration Report 2015. Retrieved from http://publications.iom.int/system/files/wmr2015_en.pdf Katz, E. \& Stark, O. (1986). Labor Migration and Risk Aversion in Less Developed Countries. Journal of Labor Economics, 4(1), 134-149. doi: 0.1.1.847.102

Mbaye, L.M. \& Zimmerman, K.F. (2016). Natural Disasters and Human Mobility. Centre for Development Research, University of Bonn.

Mohapatra, S., Joseph, G., \& Ratha, D. (2012). Remittances and Natural Disasters: Expost Response and Contribution to Ex-ante Preparedness. Environment, Development and Sustainability, 14(3), 365-387. doi: 10.1007/s10668-011-93308

Naude, W. (2010). The Determinants of migration from Sub-Saharan African countries. Journal of African Economies, 19(3), 330-356. doi:

https://doi.org/10.1093/jae/ejq004

OCHA-IDMC. (2009). Monitoring disaster displacement in the context of climate change. Retrieved from http://www.internaldisplacement.org/assets/publications/2009/200909-monitoring-disasterdisplacement-thematic-en.pdf

Stark, O. \& Bloom, D. (1985). The New Economics of Labor Migration. The American Economic Review, 75(2), 173-178. Retrieved from http://www.jstor.org/stable/1805591 
Weiss Fagen, P. \& Bump, M.N. (2006). Remittances in Conflict and Crises: How Remittances Sustain Livelihoods in War, Crises, and Transitions to Peace. Security-Development Nexus Program Policy Paper, International Peace Academy. Retrieved from https://www.ipinst.org/wpcontent/uploads/publications/remittances_erpt.pdf

The World Bank. (2006). Global Economic Prospects 2006: Economic Implications of Remittances and Migration. Retrieved from http://pubdocs.worldbank.org/en/346121443469727614/Global-EconomicProspects-2006-Economic-implications-of-remittances-and-migration.pdf The World Bank. (2016). Migration and Remittances Factbook 2016, Third Edition. Retrieved from https://openknowledge.worldbank.org/bitstream/handle/10986/23743/9781464803 192.pdf 


\section{Chapter 2: What Are the Impacts of Natural Disasters on the Remitting Patterns of Recent Canadian Immigrants?}

\subsection{Introduction}

This chapter is motivated by two emerging trends. First, there is a strong consensus

that remittances have become a significant source of development finance for many developing countries. Remittance flows are viewed as a relatively reliable, stable and growing source of external funding for many poorer countries. In 2015, there were about 232 million international migrants in the world, of which roughly 50 per cent reside in ten highly urbanized, high-income countries including Canada (International Organization for Migration $[\mathrm{IOM}], 2015)$. Migrants' remittances to developing countries reached approximately US\$441 billion in 2015 , which is approximately three times the size of official development assistance (ODA) and even greater than foreign direct investment inflows, once China is excluded (The World Bank, 2016). The graph below illustrates the magnitude and stability of remittance inflows compared to other external financial inflows into developing countries between 1990 and 2014. 
Figure 2.1: Remittance Inflows and other External Financial Inflows to Developing Countries

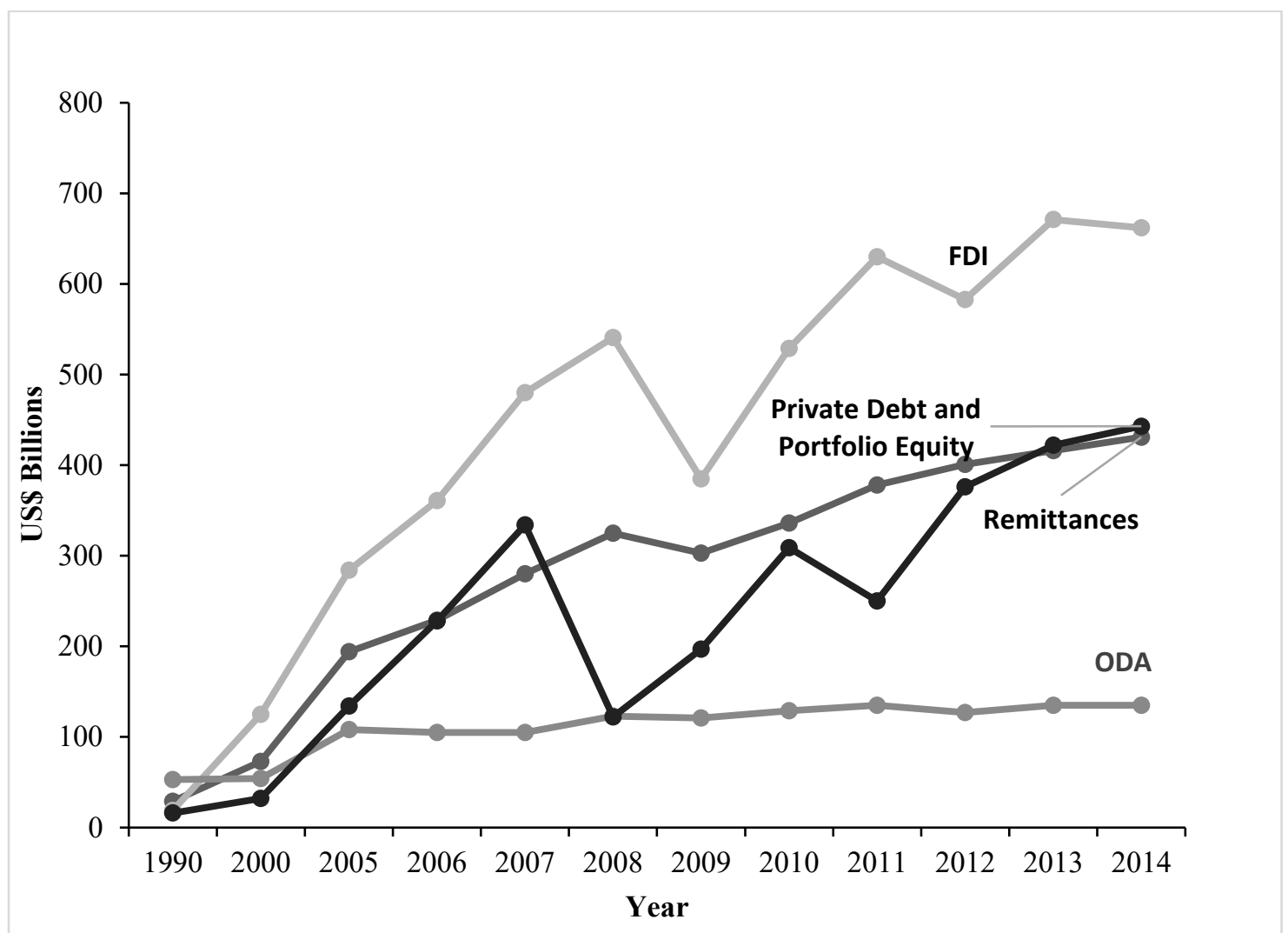

Source: The World Bank Open Data, 2016

Second, people in developing countries are particularly susceptible to the harm inflicted by the many types of natural disasters, the incidence of which have been exacerbated by a rapidly changing environment. Climate change has intensified the current vulnerabilities that make it difficult for people to survive where they are. Consequently, international migration (and remittances as a result of it) has become an increasingly common coping mechanism adopted by people confronting natural disasters (Hugo, 1996).

So, do migrants remit more in the aftermath of natural disasters in their countries of origin to mitigate income shocks adversely affecting their households back home? ${ }^{1}$

\footnotetext{
${ }^{1}$ A related risk-mitigating role for remittances is in the context of cyclical economic downturns in a migrant's home community. Durdu and Sayan (2010) find mixed evidence about how remittances respond to cyclical downturns. Their analysis of Mexican data found that remittances responded in a countercyclical manner during a financial crisis. However, in the case of Turkey they find that remittances responded in a pro-cyclical
} 
Utilizing large sample data from Statistics Canada's Longitudinal Survey of Immigrants to Canada (LSIC) as well as the disaster data from the International Emergency Disasters Database (EM-DAT), this chapter investigates the responsiveness of remittances sent by recent Canadian immigrants in the aftermath of natural disasters in their countries of origin.

This chapter makes a unique contribution to the existing literature in two major ways. First, at the Canadian national level, there is a lack of in-depth research on Canadian immigrants and their remitting behaviour. The examination of remittance data for Canadian immigrants has been conducted largely without reference to events and conditions in their countries of origin. Of the few studies that focus on remittances, none examines the responsiveness of remittances in the aftermath of natural disasters in immigrants' countries of origin. This study will be the first of its kind using a Canadian dataset examining how immigrants to Canada remit in the aftermath of natural disasters affecting their families back home. Second, at the international level, there are also only a handful of micro level empirical studies that examine the relationship of remittances in the aftermath of natural disasters. Most of these studies examine the relationship using one country of origin; however, given that the LSIC database contains immigrants originating from various regions of the world, this chapter examines this relationship for many regions. Furthermore, the majority of these existing international studies tend to focus on the characteristics of the remittance recipients (households receiving remittances) rather than those of the remitters, which the LSIC data enables this chapter to do.

manner. Sayan and Tekin-Koru (2012) also find that remittance flows from Germany to Turkey move procyclically with the output in Turkey, and are primarily driven by the developments in the Turkish economy. 
This chapter identifies several hypotheses which are tested using Tobit model estimates of the impact of various forms of natural disasters on migrants' remitting patterns. In doing so, this chapter also estimates the role of other micro-level determinants (such as age, sex, marital status, education levels, membership in community organizations) on migrants' remitting tendencies.

The remainder of this chapter is structured as follows. Section 2.2 provides a review of the existing literature on migration and remittances. Section 2.3 describes the methodology and provides background information about the sample construction and estimating procedure. Section 2.4 discusses the findings of the chapter while, Section 2.5 presents sensitivity analysis of the results. Section 2.6 concludes the chapter.

\subsection{Literature Review}

\subsubsection{Theoretical Frameworks}

Remittances and their impact at various levels have been a constant source of debate and interpretation among researchers. At a theoretical level, there is no single coherent theory regarding international migration and remittances, rather, there is a group of theories rooted in various disciplines (such as economics, political science, and sociology) that are often incompatible or irreconcilable due to the differences in their objectives, levels of analysis, and analytical focus (Anghel \& Horvath, 2009; Porumbescu, 2015). The remittance and migration literature has expanded from considering the array of variables that seem to impinge upon and are affected by spatial labour supply decisions to include the role of wider social entities and interactions influencing migratory behaviour (Stark \& Bloom, 1985). Rooted in the field of economics, one of the first theories explaining 
international migration is the neoclassical economic theory. ${ }^{2}$ Until the emergence of the New Economics of Labour Migration (NELM) theory in the 1980s, migration scholars in the economics tradition predominantly viewed migration as a decision made solely by the migrant to maximize their own income. The starting point of NELM theory is that the decision to emigrate is not made at an individual level, rather, it is a decision that potential migrants make along with others, including immediate family members and extended households. The members of these groups collaborate to maximize elements of their joint welfare by enhancing earnings or minimizing risks. NELM theory and its extensions suggest that one environmental risk-mitigation strategy commonly adopted by households is to engage in labour migration as a means to diversify household income sources (Katz \& Stark, 1986; Stark \& Bloom, 1985). Based on NELM theory, Cerón Monroy (2004) argues that for migrants, emigrating to send remittances home is a rational choice - a hedge against domestic economic downturns. In analyzing migration and remittance data from three traditional migrant-sending states in Mexico, Cerón Monroy concluded that remittance income should be viewed as supplemental income that migrants provide through diversifying their household income sources - it should not be viewed as additional savings. Migration is viewed as an investment and remittances are labelled as a return on that investment. Migrants send remittances to secure and smooth their families' consumption levels in a context of missing or imperfect financial and insurance markets

\footnotetext{
${ }^{2}$ The neoclassical economic theory is focused on the wage differences between countries and views migrants as individual rational actors deciding to migrate based on a cost-benefit analysis (Massey et al., 1993). Other theories of migration such as "the dual work market theory and the global systems theory ignore, in general, the processes of adopting the decision to migrate on a micro level, focusing, in turn, on the forces that act on a larger scale. Dual work market theory links immigration to the structural requirements of the modern industrial economies, while the latter sees immigration as a natural consequence of the economic globalization and vanish [sic] of the national borders under the pressure of the international markets" (Porumbescu, 2015, p.2).
} 
(Gubert, 2002). The prospect of receiving remittances "is often a key element in the motivation to migrate in the first place" (Carling, 2008, p. 582).

Considerable attention has also been given to understand the motives behind immigrants sending remittances to their families left behind. Many scholars have attributed altruism as a motive behind sending remittances (Cox, 1987; Cox, Eser \& Jimenez, 1998; Lucas \& Stark, 1985; Secondi, 1997). According to Johnson and Whitelaw (1974) remitters derive utility from ensuring a certain level of consumption for their families left behind. This hypothesis was later confirmed by Lucas and Stark (1985) and Stark and Lucas (1988) where they refer to this model as one of pure altruism. Others have indicated that remittances increase to compensate relatives for negative shocks to their income (Agarwal \& Horowitz, 2002). Lucas and Stark (1985) also developed an alternative to pure altruism as a theory of remittances. This theory focuses on migrant's purely self-interested reasons behind remitting. According to this theory, migrants remit for a variety of self-interested reasons including remitting to parents to ensure a future inheritance, investing in assets and entrusting left-behind family members to take care of those assets, and, lastly, ensuring that if they return home, they will have sufficient assets and social and political influence. In addition to these two theories, Lucas and Stark (1985) also put forward another theory referred to as "tempered altruism" or "enlightened self-interest." This theory is conceptualized as a self-enforcing cooperative contractual arrangement between the migrant and the extended family (Glytsos, 2002). Lucas and Stark (1985) provided two reasons behind this contractual arrangement. First, it is assumed that more educated members of the family will migrate and they will in turn remit to their families as a repayment for the initial costs of investing in human capital that the families made towards them (Glytsos; 1988; Lucas \& Stark, 1985). Second, in the presence of incomplete 
insurance and capital markets, there is a mutually beneficial agreement between the migrants and their families. Migrants' remittances provide insurance during adverse economic times affecting their households in the countries of origin (Gubert, 2002; Lucas \& Stark, 1985).

Over the past few decades, explanations for migration have also changed to emphasize the affiliations that "migrants maintain to families, communities and causes outside the boundaries of the nation-states to which they have immigrated (host country)" (Vertovec, 2001, p. 574). This insight in turn influenced the evolution of theories of transnationalism and the way migrant scholars viewed contemporary migration practice. This field of study has undergone substantial broadening since it was first conceived. ${ }^{3}$ While the degree "to which transnationalism constitutes a novel field of social praxis is still an issue open to debate (Portes, Guarzino, \& Landolt, 1999) it is, nonetheless, a valuable tool for the evaluation of the content of that praxis" (Mamattah, 2006, p. 1). The importance of transnational theory is more prevalent in situations in which an immigrant group is small and disparate. This chapter, however, deals with a large sample of immigrants hailing from different regions across the globe.

The theoretical premise of this chapter is rooted in the assertions put forward by the NELM framework and the associated perspective of tempered altruism. Specifically, this chapter tests the responsiveness of remittances sent by recent Canadian immigrants in the aftermath of natural disasters - do immigrants remit more to compensate for the income shocks affecting their households in their countries of origin as a result of natural disasters?

${ }^{3}$ Glick Schiller, Basch and Blanc-Szanton's 1992 definition is generally acknowledged as the first to recognise transnationalism as a sociological theory. 
In doing so, this study also examines how individual characteristics influence general remitting tendencies.

\subsubsection{Canadian Remittance Literature}

Although researchers across the globe have been exploring the determinants of remittances, there is limited research done on the determinants of remittances sent by recent Canadian immigrants. Simmons, Plaza, and Piché (2005) examined the remittance-sending practices of 150 immigrants of Haitian origin to Canada and 138 immigrants of Jamaican origin to Canada who have been living in Canada for at least one year. This study mainly examined the institutional barriers (transaction costs) immigrants faced in sending remittances to their origin countries. The study concluded that "Canadian residents who were born in less developed countries may have very strong attachments and commitments to members of their families who have not emigrated" (p.16). Broadly speaking, a great deal of Canadian research continues to focus on the labour market and the income characteristics of the recent immigrants (Houle \& Schellenberg, 2008b).

There are few existing papers that use the same data source (Longitudinal Survey of Immigrants to Canada) as this chapter and focus on understanding some of the general remitting patterns of recent immigrants to Canada. None of these existing papers examine the linkages between remittances and natural disasters.

One of the first papers using LSIC datasource is authored by Houle and Schellenberg (2008a; 2008b) followed by Unheim and Rowlands (2012). Both these papers investigate the general remitting trends of the recent immigrants to Canada and how migrant's characteristics influenced their remitting patterns. While the focus of this chapter is on remittances responses to home country disasters, these earlier papers provide an analysis of the basic patterns that should also be observed in this study. 
There are few other recent papers that discuss general remitting patterns of specific groups who immigrants to Canada. For instance, the article by Loxley, Sackey and Khan (2015) provides a profile of recent African immigrants in Canada. Their analysis shows that about one-third of African immigrants in Canada have a Bachelor's degree or higher, and that the stock of African immigrants increased by 31 per cent over a five-year period, while total remittances from Canada to Africa doubled. They also found that with increase in age, immigrants remitted less - those who are over 55 years old remitted less. This influence of age on remittances is similar to what Unheim and Rowlands (2012) found in their paper.

Another recent article by Chowdhury and Das (2016) examines the differences in remittance behaviour of Chinese and Indian immigrants in Canada in relation to their socioeconomic characteristics. Their results indicate that for Chinese immigrants to Canada, age, income, level of education and investment in the home country are important determinants influencing remitting patterns. For Indian migrants, factors such as marital status, having family members in Canada and involvement with ethnic organizations in Canada are the major drivers of remitting behaviour.

Similarly, another paper focused on the immigrants from Philippines to Canada and how sending remittances abroad affected the lives of these remitters living in Canada (Shooshtari, Harvey, Ferguson, Heinonen, Khan, 2014). Some of the main findings of this paper include that over time remitter's own health was not affected by remitting. However, their housing and living conditions were affected. Remitters were less likely to own their homes and more likely to rent compared to non-remitters. The focus of this paper is significantly different from that of this chapter. 
Broadly speaking, the existing Canadian literature provides only a limited general foundation (e.g., effect of age, marital status, education, membership in ethnic organizations) against which some of the findings of this chapter can be compared and contrasted. Explanatory variables included in this study's estimation are based on a review of both Canadian and international remittance literature. The findings of this chapter are generally in line with the various remitting patterns observed by these Canadian studies.

The next subsection of the literature review presents the general remitting patterns from the Canadian data [Houle \& Schellenberg (2008a; 2008b); Unheim \& Rowlands (2012)] alongside research from other countries.

\subsubsection{Demographic Characteristics and Remittances}

A number of studies examine the correlation between various demographic characteristics (sex, age, marital status, education levels) of the immigrants and their remitting patterns. The literature is inconclusive in relation to the effect of the sex of immigrants on their remitting behaviour. Massey and Parrado (1994) find that women remit less often than men whereas Vanwey (2004) and Lucas and Stark (1985) find that women tend to remit more often than their male counterparts. The two papers focused on the Canadian dataset found that there is a modest correlation between immigrant's sex and their remitting behaviour (Houle \& Schellenberg, 2008b; Unheim \& Rowlands, 2012). Both found that male immigrants remitted more than their female counterparts. What is not clear, however, is whether women remit less because their earnings are also less, and whether there are other key factors that affect sex-differentiated remittance behaviour.

Age is another crucial factor influencing the remitting patterns of immigrants. Ghosh (2006) indicates that there is a direct relationship between a migrant's age and the amount he/she remits. His research indicates that younger migrants (under 40) remit more. 
In contrast, other studies indicate a non-linear relationship, that is, an inverted U-shape relationship between age and the average amount remitted: remittances rise with age but at a decreasing rate (Houle \& Schellenberg, 2008b; Menjivar, DaVanza, Greenwell \& Valdez, 1998; Merkle \& Zimmermann, 1992 Unheim \& Rowlands, 2012).

Scholars have also highlighted the marital status of migrants as a factor determining remitting tendencies. Current literature states that married migrants remit more if they left their spouse behind in the country of origin (Durand, Parrado, \& Massey, 1996). However, if a spouse accompanies the immigrant to the host country, they are less likely to remit. A study by Collier, Piracha and Randazzo (2011) on migrants from Algeria, Tunisia and Morocco reaches a similar conclusion. In analyzing the LSIC data, Unheim and Rowlands (2012) found that marital status did not have any significant influence on migrant remitting patterns.

Similarly, a number of studies also indicate that immigrants are more likely to remit when close family members still reside in the country of origin (Funkhouser, 1995; Menjivar et al., 1998; Stanwix \& Connell, 1995; Vanwey, 2004; Vete, 1995). Conversely, remittances are negatively associated with the presence of family members in the host country. In their analysis of the LSIC data, Unheim and Rowlands (2012) find that household size of migrants in Canada is negatively related to the amount they remit. This finding supports the theory that an important motivation to remit is based on providing for the immediate family first and confirms the need to understand the role of cross-border family networks.

Research also shows that, other things being equal, remittance behaviour is strongly related to the financial capacity of immigrants to do so. There is a positive relationship between the household income of immigrants in the host country and the level of 
remittances sent (Brown and Piorine, 2005; Funkhouser, 1995; Menjivar et al., 1998). In addition to financial capacity, remitting behaviour is also affected by potential earnings, as measured by human capital characteristics such as education. There is currently no consensus in the literature about this. Funkhouser's (1995) research indicates that higher levels of education are negatively correlated with the incidence of remitting, however, among migrants who do remit, those with higher levels of education remit more. Massey and Basem (1992) state that human capital factors do not affect the decision to remit, but they are correlated with the amount migrants remit. On the contrary, Menjivar et al. (1998) find no significant correlation between education and the remitting patterns of migrants. Both Unheim and Rowlands (2012) and Houle and Schellenberg (2008b) found that the probability of remitting is not significantly associated with the level of education that immigrants had when they arrived in Canada. There are credible explanations suggesting that the relationship between education and remitting patterns may run in either direction. On the one hand, more educated migrants may have access to better jobs and thus may be more likely to remit as they have the financial capacity to do so. On the other hand, more educated migrants may come from families that are financially well-off and therefore are in less need of financial support from migrants living abroad. Furthermore, it is possible that education causes migrants to become less engaged psychologically to their home communities and make them behave more independently, or that recent better-educated migrants may focus first on getting settled in the host community before establishing a sustained pattern of sending money home. The fact that this relationship can run either way does not fit neatly into the theory of tempered altruism conceived by Lucas and Stark (1985) where one of their claims is that more educated members of the family will migrate 
and they will in turn remit to their families as a repayment for the costs/investments in human capital that the families made towards them.

In addition to the determinants discussed above, remittance patterns are also influenced by the country of origin of migrants. In this case, differences in remittance patterns could be explained by "the differences in the institutional characteristics of remittance corridors and the ease and transparency with which funds may be sent" (Houle \& Schellenberg, 2008a, p. 12). The 2006 Economic Implications of Remittances and Migration World Bank report suggests that in certain countries (e.g., Dominican Republic, El Salvador) over 80 per cent of the remittances are sent using formal channels and are thus recorded, whereas in many other countries (e.g., Bangladesh, Uganda) more than half the remittances are sent using informal channels and are thus not recorded. The report states that these unrecorded or informal flows of remittances contribute to underestimating the actual flows of remittances. Based on household surveys and econometric analysis, this 2006 World Bank Report states that "unrecorded flows through informal channels may conservatively add 50 per cent (or more) to the official recorded flows" (p. xiii) going into the developing countries.

\subsubsection{Remittances and Natural Disasters}

A review of the literature on remittances in the context of natural disasters suggest that remittance inflows increase or at least remain stable in the aftermath of natural disasters (Mohapatra, Joseph, \& Ratha, 2012; Yang, 2007; The World Bank, 2006). For instance, Yang's (2007) analysis of hurricane occurrences indicates that hurricane damages lead to increases in remittance inflows for poorer countries. His analysis includes countries from South Asia, Africa, Central America and the Caribbean. A cross-country analysis of disaster events in 129 countries for the period 1970-2006 by Mohapatra et al. (2012) 
indicate that remittances increase in the aftermath of natural disasters in countries that have a large number of migrants living abroad. Mohapatra et al. (2012) also utilized micro-level household data for a few countries including Bangladesh, Burkina Faso, Ethiopia and Ghana to further examine how migrants from these specific countries contribute to ex-post disaster relief for the affected households, and to ex-ante preparedness against future natural disasters. Their analysis of household survey data in Bangladesh indicates that per capita consumption was higher in remittance-receiving households than in others after the 1998 flood. Ethiopian households that received remittances relied more on cash reserves and less on selling household assets or livestock to cope with drought.

The literature also highlights the importance of remittances in recovering from natural disasters. In analyzing Indonesian data, Wu (2006) concluded that remittancereceiving households recovered faster in the aftermath of the 2004 tsunami. Similarly, Suleri and Savage (2006) examined the post-disaster effects of the 2005 Pakistan earthquake and found that remittances were indeed a significant factor in the recovery and reconstruction of the four villages being studied. A different study by Clarke and Wallsten (2004) using panel data examined remittances post the 1992 disaster in Jamaica. They found that remittances significantly contributed to the post-disaster relief efforts.

\subsection{Methodology: Data, Sample Construction and Estimating Procedure}

The empirical analysis in this chapter is based on data from two reliable datasets: Statistics Canada's Longitudinal Survey of Immigrants to Canada (LSIC) and the disaster data from the International Emergency Disasters Database (EM-DAT). These data sets are described in detail below. 


\subsubsection{Longitudinal Survey of Immigrants to Canada (LSIC)}

The LSIC, jointly conducted by Statistics Canada and Citizenship and Immigration Canada (CIC), is a survey of immigrants who arrived in Canada between October 1, 2000 and September 30, 2001, who were 15 years or older and have applied through a Canadian Mission abroad. ${ }^{4}$ The sampling frame for the LSIC is CIC's administrative database of all landed immigrants to Canada. The survey used two-stage stratified sampling. The first stage included selecting immigrating units ${ }^{5}$ using a probability proportional to size and the second stage included randomly selecting one member/respondent within each immigrating unit (Houle \& Schellenberg, 2008b). Experiences of temporary residents in Canada (e.g. those with temporary work permits) are outside the scope of the LSIC survey. ${ }^{6}$ Therefore, this chapter will not be able to compare the remitting behaviours of permanent versus temporary immigrants.

The LSIC is a confidential three-stage immigrant survey involving a longitudinal design with immigrants being interviewed at three different times: at six months (wave 1), two years (wave 2), and four years (wave 3) after landing in Canada. The sample design has been developed using a "funnel-shaped" approach where only immigrants who responded to the wave 1 interviews were traced for the wave 2 interviews and only those who responded to the wave 2 interviews were traced for the wave 3 interviews (Statistics Canada, LSIC Wave 3, n.d.). During the wave 1 of LSIC interviews, approximately 12,000 immigrants were interviewed. During wave 2, 9,300 of the same immigrants were

\footnotetext{
${ }^{4}$ Individuals who applied and landed from within Canada were excluded from the survey since they may have been in the country for a considerable length of time before "landing" and may therefore demonstrate different experiences and characteristics than those arriving recently from outside of Canada.

${ }^{5}$ An "immigrating unit" is comprised of individuals who applied together to immigrate to Canada.

${ }^{6}$ In 2005 (during the wave 3 interviews), there were approximately 160,000 foreign nationals residing in Canada on temporary work permits (Citizenship and Immigration [CIC], 2007).
} 
interviewed and 7,716 of the same immigrants were interviewed as part of wave 3 (Schellenberg \& Maheux, 2007). Information regarding the dependent variable of interest of this chapter (remittances sent) was only collected during wave 2 and wave 3 of the survey.

These final 7,716 respondents in wave 3 are the focus of this chapter. This group of respondents interviewed in all 3 waves of the survey are nationally representative of approximately 157,600 new immigrants (Statistics Canada, LSIC Wave 3, n.d.). Separate Tobit estimations were run on wave 2 and wave 3 interview data for the same group of respondents to examine how the results are influenced by the duration of time spent in Canada (2 years versus 4 years after arrival).

It is important to note that the LSIC survey does not explicitly use the term "remittances," rather, it asks participants to report "the money that immigrants sent to their family and friends outside Canada." During wave 2 and wave 3 survey interviews, the respondents (immigrants) were asked the question, "since your last interview, have you sent money outside Canada to relatives or friends" and "how much money have you sent outside Canada to relatives or friends?" In the remittance literature, remittances are predominantly defined as money sent to family members rather than to friends in the migrant's country of origin. As a result, this chapter limits it analysis to those LSIC respondents who have families living abroad. Approximately 97 per cent of the LSIC respondents stated that they have families living abroad. Therefore, the dependent variable of interest in this chapter is the amount of money sent overseas by these immigrants to their families, the overwhelming majority of whom lived in the immigrant's country of origin (this was observed by noting that more than 90 per cent of respondents had residence in their countries of origin before immigrating to Canada). This results in the exclusion of 
256 respondents out of the 7,716 respondents, representing approximately 4,900 of the 157,600 immigrants in the landing cohort. Their exclusion has virtually no effect on model estimates. ${ }^{7}$ This exclusion resulted in a final sample of 7,460 respondents. The main findings of this chapter presented in Table 2.2 are for these 7,460 respondents. From here onwards, the money that immigrants sent to their family outside Canada will be referred as remittances and the unit of currency used in this chapter is Canadian Dollars. ${ }^{8}$ Additionally, the terms "immigrants" and "migrants" will be used interchangeable in this chapter.

Another important feature to note about the LSIC sample is that the questions regarding remitting behaviour were asked at the individual level, rather than at the family level. Therefore, the LSIC responses may underestimate the level of remittances the immigrant households/families sent home in total as it is possible that while a LSIC respondent (survey interviewee) did not send money abroad, someone else in their family did. However, this effect may not be that severe as LSIC database indicates that about 74 per cent of its respondents identified themselves as the person most knowledgeable about the family's financial situation. ${ }^{9}$ To test the sensitivity of the findings of this chapter to this potential complication, the same estimation model was run on different sample sizes (discussed in the sensitivity analysis section of the chapter). For example, sample sizes were restricted to LSIC respondents who identified themselves as "either the principal applicant or spouse of the principal applicant" and "single adult households only."

\footnotetext{
${ }^{7}$ Important to note that in some cases it is possible for migrants to send remittances to their friends. For example, a migrant may send money to a friend looking after the migrant's family members, or to close friends who may play the same roles as theorized for family members in terms of looking after property, etc. ${ }^{8}$ Remittance amounts reported have not been adjusted for inflation. Inflation over two years during this period was approximately five per cent, so cross time comparisons will need to be adjusted accordingly. ${ }_{9}^{9}$ On the contrary, there is also a possibility that when respondents replied to the question regarding how much he/she sent home (remitted), some of them may have included the amount of remittances their entire household sent.
} 


\subsubsection{Center for Research on the Epidemiology of Diseases (CRED), International Emergency Disasters Database (EM-DAT)}

The natural disasters data used in this chapter are from the CRED International Emergency Disasters Database (EM-DAT). The EM-DAT contains essential data on the occurrence and effects of over 12,000 mass disasters in the world from 1900 to present. The database is compiled from various sources, including UN agencies, nongovernmental organizations, insurance companies, research institutes and press agencies.

CRED defines a disaster as a natural situation or event which overwhelms local capacity, necessitating a request for external assistance (EM-DAT Glossary of terms; Noy, 2008). EM-DAT groups disasters into several categories including hydrological disasters caused by the occurrence, movement, and distribution of surface and subsurface freshwater and saltwater (flood, landslide, wave action), climatological disasters caused by long-lived, meso- to macro-scale atmospheric processes ranging from intra-seasonal to multi-decadal climate variability (drought, wildfire, glacial lake outburst, etc.), meteorological disasters caused by short-lived, micro- to meso-scale extreme weather and atmospheric conditions that last from minutes to days (extreme temperature, storm, etc.) and geophysical disasters originating from solid earth (earth quakes, volcanic activity, mass movement, etc.). Each of these disaster categories are not mutually exclusive and should be considered more as a typological classification.

For a disaster to be entered into the EM-DAT database at least one of the following criteria needs to be fulfilled: (1) at least 10 people are reported killed; (2) 100 people are reported as affected; (3) declaration of a state of emergency; or (4) call for international assistance to help mitigate its effects (Noy, 2008). However, it is unlikely that all disasters will provoke a response by a country's diaspora. First, some of the disasters are quite small 
in terms of casualties and damage, and are unlikely to attract significant response even from those who have emigrated from the region. Large disasters, however, are more likely to induce remittances both because of the severity, but also because of the higher probability that migrants to Canada will be from the affected region or have family members in need. Therefore, the analysis here examines different thresholds of severity to see when there is a noticeable effect on remittances. Appendix A.1 details the disasters that are included in the estimations of this chapter.

\subsubsection{Variables and Model Specification}

The model presented here tests for recent immigrants' remitting responses in the aftermath of natural disasters affecting their home countries. The dependent variable of interest is monthly remittances to their country of origin as reported by the survey respondent. For LSIC wave 2 data, monthly remittances are calculated by dividing the total amount of money immigrants sent abroad by the number of months that elapsed between their wave 1 and wave 2 interviews. Similarly, for LSIC wave 3 data, monthly remittances are calculated by dividing the total amount the immigrants sent abroad by the number of months elapsed between their wave 2 and wave 3 interviews.

The remittance variable is a mixture of discrete (zero remittances) and continuous (positive) variables. Remittance amounts could be seen as arising from a two-step decision process (whether or not to remit, and then how much to remit if remitting) or from a single concurrent decision. The latter process is assumed here, and thus this chapter uses a Tobit estimation process with a set of 32 independent variables (defined in Appendix A.2) to 
investigate the responsiveness of migrants' remitting behaviours in the aftermath of natural disaster affecting their countries of origin. ${ }^{10}$

The estimating model was checked to confirm that there was no multicollinearity by examining the variance inflation factors (VIF). The lack of multicollinearity between variables such as education and income is most likely due to the issues of recognizing foreign employment and/or education credentials for the sample of recent immigrants. The absence of a direct relationship between education and income in this sample allows for a more direct assessment of how education affects remittances independent of its effect on income.

Table 2.1 summarizes some of the important characteristics of the immigrants and their remitting patterns for the sample considered (based on wave 2 and wave 3 data). ${ }^{11}$

Table 2.1: Weighted Sample Means of Migrant Characteristics in Waves 2 and 3

\begin{tabular}{|l|c|c|}
\hline & $\begin{array}{c}\text { Wave 2 (data between 6-24 } \\
\text { months after landing) }\end{array}$ & $\begin{array}{c}\text { Wave 3 (data between } \\
\mathbf{2 5 - 4 8} \text { months after } \\
\text { landing) }\end{array}$ \\
\hline Variables & Weighted Mean & Weighted Mean \\
\hline Total Household Income (C\$) & 43,870 & 53,247 \\
\hline Immigrant's personal income (C\$) & 17,019 & 22,723 \\
\hline $\begin{array}{l}\text { Size of immigrating unit (number of } \\
\text { members of household who immigrated } \\
\text { with the survey respondent) }\end{array}$ & 2.67 & 2.67 \\
\hline $\begin{array}{l}\text { Monthly remittances sent by those } \\
\text { migrants who remit (C\$) }\end{array}$ & 150 & 141 \\
\hline Monthly remittances sent by all migrants & 32 & 39 \\
\hline Number of jobs held since arrival & 1.32 & 1.87 \\
\hline Years of Education & 15 & 15 \\
\hline Age & 37 & 38 \\
\hline
\end{tabular}

${ }^{10}$ To test if the two-stage decision making model was applicable in this scenario, this chapter ran a probit model (first stage) and an ordinary least-squares (OLS) model (second stage). The probit and OLS did not yield significantly different results from those reported for the Tobit model. Additionally, several Heckman models were run to see if there was presence of possible selection bias. Stata provides a likelihood ratio test of the null hypothesis that the residuals of the selection equation and the main estimation are independent. If independent, there is no selection bias and the regular regression results should be unbiased. In this case the null hypothesis cannot be rejected, and thus it is not necessary to correct the estimations here for selection.

11 The summary statistics reported here are the weighted sample characteristics. The LSIC database is structured as a representative sample. As a result, the raw data for summary statistics and the estimations need to be adjusted to reflect the proper weights of the sample relative to the population. 
LSIC data indicate that within two years after arriving in Canada, 23 per cent of the immigrants remitted and that between two and four years after arrival, 29 per cent of the immigrants remitted. As noted in Table 2.1 (above), among those who remitted during the first 24 months, the average monthly remittances sent were $\mathrm{C} \$ 150$. For those who remitted during the 25 to 48 months' period after landing, remitted on average $\mathrm{C} \$ 141$ per month. It is interesting to note that, in real terms, average monthly remittances fell by about 10 per cent between wave 2 and wave 3 .

In relation to the natural disaster variables (entered as independent variables), this chapter uses CRED's three reported variables to measure the magnitude of the disaster: a) the number of people killed during the disaster b) total number of people affected by the disaster, and c) total amount of direct damages due to the disaster. Monthly disaster events examined in this chapter are those that occurred in the individual migrant's country of origin at the time that corresponds with his/her LSIC interview date. ${ }^{12}$ Due to the volume of the country specific data, the information presented in Table 2.2 and Appendices A.3A.6 in this chapter are categorized under different world regions. A break-down of regions by countries are presented in Appendix A.7.

The disaster data are then analyzed with monthly remittance data to explore the relationship between the amounts of remittances being sent with the occurrence of natural disasters in the countries of origin. The expectation is that the relationship will be positive, indicating that migrants increase remittances to help offset at least some of the losses caused by the disaster at home. It is also possible, however, that disasters could repel

\footnotetext{
12 The LSIC data provides the exact interview date and the CRED database also contains exact dates of natural disasters. For those disasters that occurred for longer duration, that is for over a month or two, (e.g. in the case of flooding), it was coded as such and analyzed with monthly remittance data for those months.
} 
remittances in the short run because of the possible difficulty in locating family members and finding ways of getting money to them securely. For this reason, the statistical tests used here will be two-tailed.

\subsection{Empirical Results and Discussions}

The main objectives of this chapter are to answer the questions: a) "Do migrants remit more in the aftermath of natural disasters in their countries of origin?" b) "How do migrants ' personal and household characteristics affect their remitting behaviour?"

Separate Tobit estimations were run for wave 2 and wave 3 interview data for the same group of respondents $(n=7,460)$ to explore these questions and also examine how the results are influenced by the duration of time spent in Canada (two years versus four years after arrival). Table 2.2 presents the results from the Tobit estimations. The sub-section below details the various findings associated with the two main objectives of the chapter. The full definitions of the variables and their statistical characteristics appear in Appendix A.2. Overall the pseudo R-squared value is higher in wave 3 than wave 2. Given that the sample sizes are the same for both the waves, the increased explanatory power shows that the responses are less variable after immigrants have been in Canada longer.

\subsubsection{Remittances Increase in Response to Natural Disasters}

To focus on natural disasters that are particularly severe or widespread, thresholds were used to restrict the disasters captured in the estimation. These thresholds were established and tested for each of the three disaster variables representing the severity of each disaster: the number of people killed, the number of people affected, and the total damages estimated for each disaster. Focusing on severe disasters is important, since the CRED database includes many relatively minor events, and the likelihood that these would affect a Canadian immigrant's family in their home country is quite remote. Therefore, a 
number of thresholds were tested, and while the direction of the effect was always consistent (remittances increase in response to disasters), the coefficient estimates were not statistically significant if the threshold was set too low. For example, immigrants remit statistically significantly more in the aftermath of natural disasters that cause damages of C\$1 million or more in their countries of origin (threshold 1). When damages less than C\$1 million are used as the explanatory variable, its coefficient estimate is positive but is not statistically significant. Similarly, when a disaster affects 5 million people or more (threshold 2), migrants respond by remitting significantly more. When values less than 5 million are used as the explanatory variable, its coefficient estimate is positive but is not statistically significant. Finally, immigrants remit statistically significantly more when the number of people killed in the disaster is 15,000 or more (threshold 3 ). When fewer than 15,000 fatalities are used as the explanatory variable, its coefficient estimate is positive but is not statistically significant. ${ }^{13}$ Table 2.2 below presents results for the damage threshold of C\$1 million or more (threshold 1). Appendices A.3 and A.4 present results for the other two thresholds - disasters affecting 5 million people or more (threshold 2) and disasters where 15,000 or more people were killed (threshold 3). The analysis that follows in this chapter hereafter refers to the coefficient figures reported in Table 2.2. Note that for each of these three thresholds (total damages $\geq \mathrm{C} \$ 1$ million, total number of people affected $\geq 5$ million and number of people killed due to disaster $\geq 15,000$ ), the analysis is done using

\footnotetext{
${ }^{13}$ These three thresholds were determined using a trial and error method. Several other thresholds for each of these natural disaster variables were tested to identify at which point (severity) the disaster was associated with a statistically significant impact on remitting patterns. The identified thresholds are the minimum points from where onwards the impact on remitting patterns became statistically significant. For all the other thresholds that were tested, while the direction of the effect was always consistent (remittances increase in response to disasters), the coefficient estimates were not always (as) statistically significant.
} 
the number of people killed, number of people affected and the total amount of damages as separate measures/variables indicating the severity of the disaster. At the top of Table 2.2 and Appendices A.3 and A.4, the threshold for which the results are presented is indicated (Table 2.2: Threshold $=$ total damages $\geq$ C\$1 million; Appendix A.3: Threshold $=$ total number of people affected $\geq 5$ million; and Appendix A.4: Threshold $=$ number of people killed due to disaster $\geq 15,000$ ). This means that for Table 2.2, the variable "number killed by disaster" is the total number of people killed by a disaster that caused C $\$ 1$ million or more in damages. Similarly, in that table, "people affected by disaster" is the total number of people affected by a disaster that caused $\mathrm{C} \$ 1$ million or more in damages. Appendix A.1 details the disasters that are captured under each of the various thresholds during the wave 2 and wave 3 interview periods.

Irrespective of which of these three thresholds is being used, the results indicate that migrants remit more in response to natural disasters affecting their countries of origin. The coefficients are all statistically significant at the 1 per cent level and their magnitudes vary slightly depending on which disaster threshold is being used. For example, focusing on the wave 2 responses reported in Table 2.2 below, for disasters in which the total damages were $\mathrm{C} \$ 1$ million or more (threshold 1 ), the average recent immigrant to Canada remitted C $\$ 126$ more each month for every 10,000 fatalities. If instead, for the same threshold, the severity of the disaster is measured by the number of people being affected by it, remittances increase by $\mathrm{C} \$ 4.6$ per month for every 100,000 people affected. Finally, when disaster severity is measured by the amount of damages it costs, these immigrants increase remittances by $\mathrm{C} \$ 6.7$ per month for every $\mathrm{C} \$ 100,000$ worth of damages in total.

The analysis of wave 3 data indicates that between two and four years after their arrival to Canada, immigrants still respond by remitting more in the aftermath of natural 
disasters affecting their home countries; however, the amount remitted is smaller than what they remitted two years previously. Specifically, according to wave 3 data, the increase in monthly remittances is $C \$ 71$ for every 10,000 fatalities and $C \$ 3.7$ for every 100,000 people affected and $\mathrm{C} \$ 6.1$ for every $\mathrm{C} \$ 100,000$ worth of damages. These amounts are slightly less in real terms due to inflation.

While these remittance amounts may appear small, three things should be kept in mind. First, these amounts represent the average response via remittances sent directly to family members; respondents may also respond in other ways such as donations to relief organizations. Second, many of those in the survey may not have had any of their immediate or extended families in their home country affected directly by the disaster, so there would be no associated adjustment to remittances (though there may have been a response by donating to relief agencies in this case). The more catastrophic the event, the higher the probability that some immigrants to Canada from the affected region would have family members impacted by the disaster. So, for example, during the wave 2 interview period, the estimated effect of disasters on remittances may reflect larger responses by the families directly affected being balanced out by smaller responses by those who are less affected. Third, while these responses may seem small in Canadian dollars, once converted into local currencies, the purchasing power may be considerably higher. Many of the countries in the sample adversely affected by disaster are relatively poor, and hence market exchange rates may tend to systematically understate the purchasing power of remittances in those countries. Fourth, these responses are averaged over roughly 24 months; if concentrated in one or two larger installments, these responses would appear more substantial. Finally, while examining the volume of remittances that immigrants sent home in response to natural disasters, it is important to note that they may opt to send remittances 
through informal channels (such as through friends or relatives as discussed in the literature review section). Further, as stated earlier, the LSIC data on the amount of remittances immigrants sent home were collected at an individual level, rather than at the family level. So, it is plausible that the increase in the level of remittances sent at the aftermath of natural disasters could be higher than what is estimated.

Estimations in Appendices A.3 and A.4 for the other two thresholds (total number of people affected $\geq 5$ million and number of people killed due to disaster $\geq 15,000$ respectively) reach similar conclusions - migrants respond by remitting more in the aftermath of natural disasters affecting their home countries. Note that when the sample sizes are restricted to single adult households only (Appendix A.5) or to respondents who identified themselves as either the principal applicant or spouse of the principal applicant (Appendix A.6), the conclusions remain the same.

Using interactive variables, this model also tested to see if immigrants remitting patterns post natural disasters affecting their home countries were influenced by their individual characteristics, such as sex, marital status, membership in a community group and immigration category. Results (not presented in the tables) indicate that none of these characteristics have any significant influence on remitting patterns associated with natural disasters.

Having presented the findings answering the main research question of this chapter (how disasters affect remittance patterns), the remainder of this chapter will examine how migrants' personal and household characteristics impact their remitting behaviours. 
Table 2.2: Tobit Estimations for Monthly Remittance Levels (T-statistics are in brackets below the coefficient)

\begin{tabular}{|c|c|c|c|c|c|c|}
\hline \multirow{2}{*}{ Variables } & \multicolumn{3}{|c|}{ Wave 2} & \multicolumn{3}{|c|}{ Wave 3} \\
\hline & \multicolumn{3}{|c|}{ Threshold: Total Damages $\geq \$ 1 \mathrm{M}$} & \multicolumn{3}{|c|}{ Threshold: Total Damages $\geq \$ 1 \mathrm{M}$} \\
\hline $\begin{array}{l}\text { Total Household Income } \\
\text { (in } \$ 1000 \text { s) }\end{array}$ & $\begin{array}{r}2.34 * * * \\
(4.24)\end{array}$ & $\begin{array}{r}2.69 * * * \\
(4.39)\end{array}$ & $\begin{array}{r}2.83 * * * \\
(4.42)\end{array}$ & $\begin{array}{r}1.93 * * * \\
(6.43)\end{array}$ & $\begin{array}{r}1.87 * * * \\
(5.97)\end{array}$ & $\begin{array}{r}1.68 * * * \\
(5.54)\end{array}$ \\
\hline (Total Household Income) $^{2}$ & & & & & & \\
\hline (in $\$ 1000000$ s) & $\begin{array}{r}-0.0013 * * \\
(-2.24)\end{array}$ & $\begin{array}{r}-0.0015^{* *} \\
(-2.40)\end{array}$ & $\begin{array}{r}-0.0016^{* *} \\
(-2.45)\end{array}$ & $\begin{array}{r}-0.0013 * * * \\
(-4.28)\end{array}$ & $\begin{array}{r}-0.0012 * * * \\
(-4.06)\end{array}$ & $\begin{array}{r}-0.001 * * * \\
(-4.01)\end{array}$ \\
\hline Number of Jobs & $\begin{array}{r}83.72 * * * \\
(3.88)\end{array}$ & $\begin{array}{r}68.98 * * * \\
(3.53)\end{array}$ & $\begin{array}{r}67.27 * * * \\
(3.50)\end{array}$ & $\begin{array}{r}45.57 * * * \\
(3.88)\end{array}$ & $\begin{array}{r}25.67 * * \\
(2.43)\end{array}$ & $\begin{array}{r}25.15 * * \\
(2.36)\end{array}$ \\
\hline$(\text { Number of Jobs) })^{2}$ & $\begin{array}{r}-10.39 * * * \\
(-2.90)\end{array}$ & $\begin{array}{r}-7.99 * * \\
(-2.38)\end{array}$ & $\begin{array}{r}-8.16^{* *} * \\
(-2.45)\end{array}$ & $\begin{array}{l}-3.5 * * \\
(-2.39)\end{array}$ & $\begin{array}{r}-1.84 * * \\
(-2.36)\end{array}$ & $\begin{array}{r}-1.84 * * \\
(-2.76)\end{array}$ \\
\hline Immigrating Unit Size & $\begin{array}{r}-38.51 * * * \\
(-4.47)\end{array}$ & $\begin{array}{r}-37.37 * * * \\
(-4.39)\end{array}$ & $\begin{array}{r}-32.95 * * * \\
(-4.08)\end{array}$ & $\begin{array}{r}-30.92 * * * \\
(-5.88)\end{array}$ & $\begin{array}{r}-28.17 * * * \\
(-5.18)\end{array}$ & $\begin{array}{r}-23.37 * * * \\
(-4.63)\end{array}$ \\
\hline Yrs of Formal Education & $\begin{array}{r}-17.79^{*} \\
(-1.66)\end{array}$ & $\begin{array}{l}-16.09 \\
(-1.50)\end{array}$ & $\begin{array}{l}-14.11 \\
(-1.33)\end{array}$ & $\begin{array}{l}-14.47 \\
(-1.52)\end{array}$ & $\begin{array}{l}-12.31 \\
(-1.51)\end{array}$ & $\begin{array}{l}-12.46 \\
(-1.27)\end{array}$ \\
\hline$(\text { Yrs of Formal Education })^{2}$ & $\begin{array}{r}0.3431 \\
(1.09)\end{array}$ & $\begin{array}{r}0.3442 \\
(1.06)\end{array}$ & $\begin{array}{r}0.2841 \\
(0.88)\end{array}$ & $\begin{array}{r}0.2822 \\
(1.29)\end{array}$ & $\begin{array}{r}0.2942 \\
(1.44)\end{array}$ & $\begin{array}{r}0.2831 \\
(1.50)\end{array}$ \\
\hline Age & $\begin{array}{r}11.94 * * \\
(2.06)\end{array}$ & $\begin{array}{r}15.57 * * \\
(2.41)\end{array}$ & $\begin{array}{r}15.78 * * \\
(2.39)\end{array}$ & $\begin{array}{r}17.35 * * * \\
(4.18)\end{array}$ & $\begin{array}{r}16.14 * * * \\
(3.81)\end{array}$ & $\begin{array}{r}15.95^{* * * *} \\
(3.84)\end{array}$ \\
\hline Age $^{2}$ & $\begin{array}{r}-0.1621 * * \\
(-2.36)\end{array}$ & $\begin{array}{r}-0.1941 * * \\
(-2.57)\end{array}$ & $\begin{array}{r}-0.1981 * * \\
(-2.55)\end{array}$ & $\begin{array}{r}-0.2081 * * * \\
(-4.40)\end{array}$ & $\begin{array}{r}-0.1891 * * * \\
(-3.95)\end{array}$ & $\begin{array}{r}-0.1851 * * * \\
(-3.95)\end{array}$ \\
\hline Male & $\begin{array}{r}25.55^{*} \\
(1.94)\end{array}$ & $\begin{array}{r}36.55 * * \\
(2.63)\end{array}$ & $\begin{array}{r}38.86^{* * *} \\
(2.76)\end{array}$ & $\begin{array}{r}36.22 * * * \\
(3.23)\end{array}$ & $\begin{array}{r}31.08 * * * \\
(2.86)\end{array}$ & $\begin{array}{r}28.02 * * \\
(2.78)\end{array}$ \\
\hline Married Immigrants & $\begin{array}{l}-12.52 \\
(-0.62)\end{array}$ & $\begin{array}{l}-26.83 \\
(-1.23)\end{array}$ & $\begin{array}{l}-39.27 \\
(-0.98)\end{array}$ & $\begin{array}{l}-19.95 \\
(-1.14)\end{array}$ & $\begin{array}{r}-7.05 \\
(-0.41)\end{array}$ & $\begin{array}{r}-8.77 \\
(-0.54)\end{array}$ \\
\hline Family Class Category & $\begin{array}{l}-41.76 \\
(-1.60)\end{array}$ & $\begin{array}{l}-30.47 \\
(-1.36)\end{array}$ & $\begin{array}{l}-21.13 \\
(-0.91)\end{array}$ & $\begin{array}{r}-16.38 \\
(-0.93)\end{array}$ & $\begin{array}{l}-11.23 \\
(-0.65)\end{array}$ & $\begin{array}{r}-16.95 \\
(-0.11)\end{array}$ \\
\hline Business Class Category & $\begin{array}{r}-142.67 \\
(-1.57)\end{array}$ & $\begin{array}{l}-92.58 \\
(-1.21)\end{array}$ & $\begin{array}{r}-91.34 \\
(-1.19)\end{array}$ & $\begin{array}{r}-96.85 * * * \\
(-3.92)\end{array}$ & $\begin{array}{r}-89.36 * * \\
(-2.27)\end{array}$ & $\begin{array}{r}-69.16^{* * * *} \\
(-3.60)\end{array}$ \\
\hline Refugee Class Catgory & $\begin{array}{r}-86.12 * * \\
(-2.66)\end{array}$ & $\begin{array}{r}-181.21 * * * \\
(-3.71)\end{array}$ & $\begin{array}{r}-113.36^{* * * *} \\
(-3.81)\end{array}$ & $\begin{array}{r}-79.17 * * * \\
(-3.84)\end{array}$ & $\begin{array}{r}-161.04 * * * \\
(-6.34)\end{array}$ & $\begin{array}{r}-160.82 * * * \\
(-6.42)\end{array}$ \\
\hline Ontario Resident & $\begin{array}{r}-109.33 * * * \\
(-4.10)\end{array}$ & $\begin{array}{r}-115.02 * * * \\
(-4.15)\end{array}$ & $\begin{array}{r}-113.12 * * * \\
(-4.09)\end{array}$ & $\begin{array}{c}27.44 \\
(1.50)\end{array}$ & $\begin{array}{r}21.65 \\
(1.52)\end{array}$ & $\begin{array}{r}18.79 \\
(1.48)\end{array}$ \\
\hline Quebec Resident & $\begin{array}{r}-116.56^{* * * *} \\
(-4.09)\end{array}$ & $\begin{array}{r}-158.78 * * * \\
(-3.90)\end{array}$ & $\begin{array}{r}-153.35 * * * \\
(-3.87)\end{array}$ & $\begin{array}{l}-84.58 \\
(-0.21)\end{array}$ & $\begin{array}{l}-75.06 \\
(-0.34)\end{array}$ & $\begin{array}{l}-54.17 \\
(-0.06)\end{array}$ \\
\hline British Columbia Resident & $\begin{array}{r}-97.81 * * * \\
(-2.97)\end{array}$ & $\begin{array}{r}-105.25 * * * \\
(-3.07)\end{array}$ & $\begin{array}{r}-110.11 * * * \\
(-3.12)\end{array}$ & $\begin{array}{r}25.32 \\
(1.45)\end{array}$ & $\begin{array}{r}27.42 \\
(0.45)\end{array}$ & $\begin{array}{r}36.54 \\
(0.50)\end{array}$ \\
\hline Invested Abroad & $\begin{array}{r}149.13 * * * \\
(3.60)\end{array}$ & $\begin{array}{r}182.09 * * \\
(2.27)\end{array}$ & $\begin{array}{r}196.83 * * * \\
(2.37)\end{array}$ & $\begin{array}{r}163.18 * * * \\
(4.03)\end{array}$ & $\begin{array}{r}170.88 * * * \\
(3.88)\end{array}$ & $\begin{array}{r}153.48 * * * \\
(3.85)\end{array}$ \\
\hline Community Member & $\begin{array}{r}29.57 * * \\
(2.30)\end{array}$ & $\begin{array}{r}24.89 * * \\
(2.35)\end{array}$ & $\begin{array}{r}26.45^{* * * *} \\
(2.50)\end{array}$ & $\begin{array}{r}35.96 \\
(1.02)\end{array}$ & $\begin{array}{r}23.22 \\
(1.10)\end{array}$ & $\begin{array}{r}26.07 \\
(1.35)\end{array}$ \\
\hline Eastern Europe & $\begin{array}{r}111.61 * * * \\
(3.37)\end{array}$ & $\begin{array}{r}119.17 * * * \\
(3.93)\end{array}$ & $\begin{array}{r}96.81 * * * \\
(3.96)\end{array}$ & $\begin{array}{r}103.55 * * * \\
(5.61)\end{array}$ & $\begin{array}{r}96.23 * * * \\
(7.81)\end{array}$ & $\begin{array}{r}83.57 * * * \\
(7.58)\end{array}$ \\
\hline North Africa & $\begin{array}{r}142.05 * * \\
(2.00)\end{array}$ & $\begin{array}{r}110.81 * * \\
(2.49)\end{array}$ & $\begin{array}{r}131.91 * * * \\
(2.75)\end{array}$ & $\begin{array}{r}94.13 * * \\
(2.20)\end{array}$ & $\begin{array}{r}77.22 * * * \\
(4.86)\end{array}$ & $\begin{array}{r}107.16 * * * \\
(4.14)\end{array}$ \\
\hline West Africa & $\begin{array}{r}153.47 * * * \\
(3.78)\end{array}$ & $\begin{array}{r}164.82 * * * \\
(4.07)\end{array}$ & $\begin{array}{r}165.32 * * * \\
(4.09)\end{array}$ & $\begin{array}{r}118.94 * * * \\
(4.36)\end{array}$ & $\begin{array}{r}142.76 * * * \\
(5.72)\end{array}$ & $\begin{array}{r}123.72 * * * \\
(5.50)\end{array}$ \\
\hline East Africa & $\begin{array}{r}124.21 * * \\
(2.79)\end{array}$ & $\begin{array}{r}130.91 * * * \\
(3.54)\end{array}$ & $\begin{array}{r}126.39 * * * \\
(3.64)\end{array}$ & $\begin{array}{r}99.23 \\
(1.92)\end{array}$ & $\begin{array}{r}98.36 * * * \\
(4.49)\end{array}$ & $\begin{array}{r}92.58 * * * \\
(4.52)\end{array}$ \\
\hline Central Africa & $\begin{array}{r}109.11 * * \\
(2.80)\end{array}$ & $\begin{array}{r}124.71 * * \\
(1.98)\end{array}$ & $\begin{array}{r}118.32 * * * \\
(2.23)\end{array}$ & $\begin{array}{r}64.72 * * \\
(2.53)\end{array}$ & $\begin{array}{r}69.41 * * * \\
(3.75)\end{array}$ & $\begin{array}{r}91.09 * * * \\
(3.70)\end{array}$ \\
\hline South Asia & $\begin{array}{r}157.63 * * * \\
(2.87)\end{array}$ & $\begin{array}{r}191.86 * * * \\
(4.07)\end{array}$ & $\begin{array}{r}230.98 * * * \\
(4.07)\end{array}$ & $\begin{array}{r}96.78 * * \\
(2.30)\end{array}$ & $\begin{array}{r}109.62 * * * \\
(5.91)\end{array}$ & $\begin{array}{r}117.92 * * * \\
(5.09)\end{array}$ \\
\hline Southeast Asia & $\begin{array}{r}292.31 * * * \\
(4.06)\end{array}$ & $\begin{array}{r}255.48 * * * \\
(4.28)\end{array}$ & $\begin{array}{r}233.89 * * * \\
(4.27)\end{array}$ & $\begin{array}{r}149.52 * * * \\
(7.28)\end{array}$ & $\begin{array}{r}211.45 * * * \\
(8.88)\end{array}$ & $\begin{array}{r}205.75 * * * \\
(8.40)\end{array}$ \\
\hline Caribbean & $\begin{array}{r}282.11 * * * \\
(3.62)\end{array}$ & $\begin{array}{r}217.15 * * * \\
(3.99)\end{array}$ & $\begin{array}{r}261.95 * * * \\
(4.02)\end{array}$ & $\begin{array}{r}155.89 * * * \\
(4.46)\end{array}$ & $\begin{array}{r}178.39 * * * \\
(6.37)\end{array}$ & $\begin{array}{r}164.43 * * * \\
(6.12)\end{array}$ \\
\hline South America & $\begin{array}{r}139.25 * * \\
(2.57)\end{array}$ & $\begin{array}{r}172.89 * * * \\
(3.67)\end{array}$ & $\begin{array}{r}149.65 * * * \\
(3.77)\end{array}$ & $\begin{array}{r}131.79 * * * \\
(3.76)\end{array}$ & $\begin{array}{r}124.44 * * * \\
(4.92)\end{array}$ & $\begin{array}{r}125.75 * * * \\
(4.98)\end{array}$ \\
\hline Central America & $\begin{array}{r}98.12 * * \\
(2.23)\end{array}$ & $\begin{array}{r}138.82 * * \\
(2.69)\end{array}$ & $\begin{array}{r}124.7 * * * \\
(2.96)\end{array}$ & $\begin{array}{r}57.41 * * \\
(2.52)\end{array}$ & $\begin{array}{r}73.37 * * \\
(2.25)\end{array}$ & $\begin{array}{r}74.13 * * * \\
(3.90)\end{array}$ \\
\hline Number Killed by Disaster & $\begin{array}{r}0.0126 * * * \\
(5.21)\end{array}$ & & & $\begin{array}{r}0.0071 * * * \\
(4.67)\end{array}$ & & \\
\hline People Affected by Disaster & & $\begin{array}{r}0.000046 * * * \\
(4.99)\end{array}$ & & & $\begin{array}{r}0.000037 * * * \\
(11.30)\end{array}$ & \\
\hline Total Damages (in CAD\$) & & & $\begin{array}{r}0.000067 * * * \\
(4.75)\end{array}$ & & & $\begin{array}{r}0.000061^{* * * *} \\
(11.75)\end{array}$ \\
\hline Constant & $\begin{array}{r}-517.52 * * * \\
(-2.94)\end{array}$ & $\begin{array}{r}-751.87 * * * \\
(-3.42)\end{array}$ & $\begin{array}{r}-827.17 * * * \\
(-3.49)\end{array}$ & $\begin{array}{r}-566.38 * * * \\
(-5.17)\end{array}$ & $\begin{array}{r}-650.27 * * * \\
(-5.34)\end{array}$ & $\begin{array}{r}-623.71 * * * \\
(-5.17)\end{array}$ \\
\hline Pseudo R2 & 0.03 & 0.04 & 0.04 & 0.047 & 0.0571 & 0.0734 \\
\hline Observations & 7460 & 7460 & 7460 & 7460 & 7460 & 7460 \\
\hline
\end{tabular}




\subsubsection{Effects of Immigrants' Household and Personal Characteristics on Remittances Sent}

This section discusses the estimation results associated with the immigrant's personal characteristics and household characteristics such as household income, employment history, size of immigrating unit, level of education, age, sex and marital status. In the remittance literature, these are standard variables used to explain variation in remittance levels. The results discussed below are referenced in Table 2.2 (sample size $=7,460$ ). Note that when the sample sizes are restricted to single adult households only (Appendix A.5) or to respondents who identified themselves as either the principal applicant or spouse of the principal applicant (Appendix A.6), the conclusions remain largely the same. The sensitivity section discusses the sample size related observations further.

The LSIC data contained several different measures of immigrants' personal and household income. Some respondents reported having little personal income from their own jobs, however, the household income consisted of income from various sources, including income from other family members, the government or other family sources. The income variable used in this chapter, total household income, includes total income received from all sources by the respondent's family during the last 12 months preceding the interview date. ${ }^{14}$ The results in Table 2.2 indicate that a migrant family's total household income has a positive and a significantly strong effect on the amount of

\footnotetext{
${ }^{14}$ Important to note that the dependent variable (remittances) is a monthly variable, since the number of months for which remittances were reported varied by respondent. To keep the dependent variable in identical units, a monthly average remittance is calculated and used. As a result, the coefficient estimate presented here for the annual income variable could be adjusted by a factor of 12 to associate monthly remittances to monthly income, or annual remittances with annual income. Since annual income was reported by the respondents and as it is a common unit of measurement for income, annual income is used in the estimation. Nonetheless, the results discussed here remain accurate in terms of the reported marginal effect.
} 
remittances they sent home. Estimations indicate that migrants sent more remittances as their household income increases. The non-linear (quadratic) form of the total household income variable was also included in the estimation to examine if the trend is valid for higher levels of income. The coefficient estimates in Table 2.2 allow the relevant quadratic equation to be solved for the income at which remittances are maximized, and decline thereafter. The maximum remittances occur at household incomes of about $\mathrm{C} \$ 900,000$ per year for wave 2 and approximately $C \$ 800,000$ per year for wave 3 . As these both exceed the maximum income levels observed in the relevant samples, and greatly exceed the average household income levels, the non-linear effect is best interpreted as indicating that remittances increase with income, but at a diminishing marginal rate.

The estimated coefficients linking the number of jobs held by immigrants with the amount they remit indicate that more jobs lead to higher remittances, but also at a diminishing rate. While there may be a tendency to assume that more jobs meant the respondent had been changing jobs frequently and as a result did not have a stable source of income based on which to remit, the results of this chapter suggest otherwise. According to this chapter's findings, more jobs lead to higher remittances being sent home. These results are consistent with the idea that recent immigrants move to progressively better paying jobs with time as they acquire more Canadian labour market experiences. They may initially hold temporary jobs, or multiple jobs, while they explore the Canadian job market and gain Canadian experience. Holding several jobs may also signal the immigrant's desire to take any job and try to move up to better ones in an effort to meet the remittance expectations they or their family may have. The use of the non-linear term was to ensure if this trend is observed if the immigrants hold an unrealistic number of jobs as that is likely indicative of poor quality jobs or job instability, thus lowering the respondent's capacity to 
remit. According to estimations presented in Table 2.2, immigrants who have been in Canada for at least two years (wave 2 data), would remit more as the number of jobs they had increased. However, if they hold more than four jobs, their capacity to remit remittances decline, likely indicating poor quality jobs or job instability. When this group of immigrants have been living in Canada for longer periods (wave 3 data), the number of jobs after which they will start to reduce remittances is seven. This increase is reflective of the fact that they have been in the country longer and the number of jobs since arrival will only increase with the passing of time. For the samples examined in this chapter, it indicates that during wave 2 and wave 3 there were immigrants holding more than four jobs and seven jobs respectively. However, the percentage of those immigrants was relatively small.

The size of the immigrating unit also has a significant impact on the amount of remittances migrants sent home. For every additional member in the immigrant's household, immigrants send between $C \$ 33$ and C\$39 less following the first two years after their arrival. As time passes, although the effect remains significant, the magnitude of the effect slightly reduces to $\mathrm{C} \$ 23$ to $\mathrm{C} \$ 31$, indicating that after being in Canada for longer, the up-front costs of re-establishing family members have been dealt with. This overall effect is reflective of the existing literature that claims that immigrants who migrate with their immediate family members (partner/spouse and/or children) will remit less than those who left most of their families in the country of origin.

The estimated coefficients for the education variables in both waves 2 and 3 (linear as well as non-linear terms) indicate that there is no statistically significant relationship 
between the years of education and the remitting behaviour of recent immigrants. ${ }^{15}$ Note that this effect should be considered as occurring as a result of education itself, and not as a consequence of the effects on income, which enters the estimation directly in this chapter.

The analysis on the effect of education on remittance sent is supportive of the general observation that immigrants, particularly those who worked in specialized professions such as doctors and engineers in their home countries, need to obtain Canadian certifications or credentials before they can find comparable employment in their relevant field in Canada. Others often decide to enrol in professional or advanced degrees in Canada to get Canadian education so that they can land a job in their preferred field of work. Thus, immigrants often need to complement the education that they have received in their countries of origin (particularly those coming from lower-income countries) with Canadian education before finding gainful employment in their preferred field. The LSIC data analyzed here take into account the experiences of immigrants between 6-24 months and 24-48 months after arrival. One could argue that, if interviewed after 5-8 years of arrival into the country, immigrants who have received their Canadian degrees or other credentials may show a different propensity to remit due to increased number of educational years. Alternatively, as discussed in the literature review section, more educated migrants may come from families that are financially well-off and therefore are in less need of financial support from migrants living abroad and so the effect will remain unchanged with the passing of time. Influences of these effects and other competing explanations (as discussed in the literature review section) must await further data and analysis.

\footnotetext{
${ }^{15}$ The general insignificant relationship that is observed in the tables demonstrates that years of education is negatively related to the amount that immigrants remit. In a very few cases, for example in Appendix A.3, this negative relationship appears to be somewhat stronger for migrants who have been living in Canada for longer periods (wave 3 ).
} 
The question regarding the influence of years of education on remittances sent flows neatly into that of the effect of age on remittances sent. As discussed in the literature review section, a standard argument in this case would assert that remittances increase with age (Rodriguez, 1996). The estimated coefficients for the age variables in Table 2.2 are statistically significant, indicating that remittances increase with age. The results indicate that the remittances sent peak at around age 40 (for wave 3 , it peaks around age 43), after which remittances decline with age. This conclusion regarding age and its effects are similar to that of Merkle and Zimmermann (1992) in their analysis of German immigrant data, as well as similar to the Unheim and Rowlands (2012) study using the LSIC data. This trend may be attributed to an array of factors including the fact that, over time, the members of the family left behind in the country of origin (parents, siblings) may immigrate to Canada to join the immigrant, or perhaps because as age increases the respondent may allocate more money for purposes such as retirement planning and other costs associated with aging. Finally, over time immigrants may simply feel that they have done their duty regarding supporting their family back home, or decide to invest more of their resources into their standard of living in Canada. These contending explanations require further research, as they cannot be answered with the current LSIC data.

As discussed previously, the effect of an immigrant's sex on remitting behaviour is an area where there is no consensus in the existing literature. Results in Table 2.2 indicate that in this case, men generally remit significantly more than women. During the wave 2 interviews, male respondents remitted on average C $\$ 26$ more per month than their female counterparts, which increased to $\mathrm{C} \$ 28$ in the next survey roughly two years later. To further confirm this result, the Tobit estimations presented in Table 2.2 were run on a sample that included only single adult households interviewed during wave 2 and wave 3 (see 
Appendix A.5). The coefficient estimates for this restricted sample size indicate a similar remitting pattern: two years after landing, men remitted at a minimum $\mathrm{C} \$ 32$ more per month and with more time spent in Canada they remitted at a minimum $\mathrm{C} \$ 35$ more per month. According to the LSIC data, among those who remitted, 26 per cent were men and 23 per cent were women. On average, women sent 12 per cent less than men.

These findings are consistent with several studies (Ghosh, 2006; Massey \& Parrado, 1994) but contradict others (Gammage, 2004; Lucas \& Stark, 1985). This effect should be seen as independent of income, which is controlled for separately in the estimation. It is important to mention that the effect of the migrant's sex in understanding remitting patterns is a complex matter requiring a deeper exploration of qualitative factors such as the structure of the immigrant's family, cultural norms associated with the decisionmaking power of women within the family, and other household dynamics. In the absence of these more nuanced, yet influential, socio-cultural factors, our understanding is limited to quantitative analysis that may only portray a partial scenario. For example, Debnath's (2015) use of primary survey data to examine women's remitting patterns compared to men's, reveal that married women who migrate along with their spouses are often expected to send remittances to their husband's family (in the country of origin). Consequently, remittances that these women sent back to their home country are split between their own parents' households and their husband's parents' households. In contrast, men in a similar situation only reported remitting to their own parents or family back home (not to their wives' families). Female respondents in that study indicated that they were hesitant to reveal that they send money to their parents (thus, underreporting the true extent of how much they remit) out of fear that their husbands would disapprove and take away or redirect that amount. It is important, though challenging, to take into consideration these more 
nuanced socio-cultural factors that affect women's remitting patterns. The recent Canadian immigrant survey (LSIC) used in this chapter does not include sufficient information on such factors to generate further insights into gender and remittance behaviour.

\subsubsection{Effect of Immigration Category and Province of Residence on Remitting Patterns}

This chapter also examines the relationship between immigrants' remitting behaviour and the administrative category under which they immigrated to Canada. The three groups of immigrants presented in Table 2.2 - family class, business class and refugees - are compared to the base group of immigrants (skilled workers, provincial nominees, independent immigrants) who came to Canada at the same time as these three groups. Therefore, the results presented need to be interpreted relative to the remitting behaviour of the base group.

The estimation coefficients indicate that those who came under the family class category remit less than the base group, although the relationship observed is not statistically significant. As shown in Table 2.2, family category immigrants remitted C $\$ 21-$ $\mathrm{C} \$ 42$ less during the first two years of their arrival and $\mathrm{C} \$ 11-\mathrm{C} \$ 17$ less between the two to four years after their arrival. These results are consistent with the general expectations that family class immigrants typically immigrate to join their immediate family members (spouse and/or children) living in Canada and therefore the remittances that they send home are mainly to support their extended family (aunts, uncles, nephews, nieces, grandparents, etc.). Although family ties run deeper than the circle of the immediate nuclear family, it can be reasonably argued that this class of immigrants will be less able to send money until they have taken care of the needs of their immediate family that they have with them in Canada. 
Similarly, compared to the base group, the business category immigrants who qualified to immigrate to Canada by investing a statutory identified minimum amount also remitted less. However, this relationship observed is only statistically significant for the group that has been in Canada for relatively longer period (wave 3). During this period, business category immigrants remitted $\mathrm{C} \$ 69-\mathrm{C} \$ 97$ per month less when compared to the base group. The remitting trend of business category immigrants could perhaps be explained by two primary factors. First, investing in Canada indicates migrants' stronger ties to Canada and second, because this category of migrants tends to come from wealthier families in their home countries, their families (in their home countries) may have less financial need compared to the families of the base group. Further, family members left behind by business category immigrants may have other sources of stable income (such as from businesses in their home countries) and are less reliant on remittances sent by their immigrant family members living in Canada.

Those immigrants who arrived in Canada under the refugee category also remit significantly less than the base group. Table 2.2 indicates that they remitted $\mathrm{C} \$ 86-\mathrm{C} \$ 113$ less during the first two years of their arrival and $\mathrm{C} \$ 79-\mathrm{C} \$ 161$ less between the two to four years after their arrival. Refugees typically come to Canada with few possessions and often are escaping serious and adverse political conditions in their countries of origin. Against this context, it may be interpreted that refugees do not have adequate financial capacity to remit within the first several years of their arrival compared to the base group of immigrants who are expected to be relatively more financially stable when they first land in Canada. Additionally, it could also be that refugees may find it more difficult to send remittances because their home countries may be in conflict or have limited infrastructure, or they may 
find it more challenging to locate family members who may be displaced due to conflict or political reasons.

The province in which the immigrants settle once they arrive in Canada also plays a vital role in influencing remitting patterns. Most of LSIC's sample population chose to reside in the provinces of Ontario, British Columbia and Quebec, and particularly in the bigger cities within these provinces -Toronto, Vancouver and Montreal (Houle \& Schellenberg, 2008a; Unheim \& Rowlands, 2012). Therefore, the analysis in this chapter will focus on the remitting trend of immigrants settling in these three provinces relative to the base group (those settling in the Prairie and Atlantic provinces). No respondents resided in the north. ${ }^{16}$

The estimated coefficients indicate that residence in one of these three Canadian provinces is associated with significantly lower remittances during the first 6-24 months after landing. During this period, immigrants residing in Ontario remitted C\$109-C\$115 less compared to the base group. The corresponding levels for recent immigrants living in Quebec and British Columbia were C\$117-C\$159 and C\$98-C\$110 less, respectively. It is important to interpret these results with caution. These results do not mean that more remittances come from the base group, rather it means that immigrants living in Ontario, Quebec and British Columbia remit less per migrant compared to the base group. These results could be attributed to factors such as the higher cost of living in bigger cities such as Toronto, Montreal and Vancouver within these three provinces, coupled with their relatively high unemployment rate during 2001 (the period of arrival of the respondents). In 2001, the unemployment rate for recent immigrants in Toronto was 10.7 per cent and in

\footnotetext{
${ }^{16}$ Other provinces such as Alberta were not separated out because of the smaller sample sizes.
} 
Vancouver the rate was 12 per cent (Statistics Canada, 2006). In Montreal, the unemployment rate was 20.6 per cent compared to 5.4 per cent for the overall labour force (Statistics Canada, 2006).

However, when observing immigrants' remitting behaviours between 2-4 years after arrival those who lived in Ontario and British Columbia remitted more compared to their counterparts living in the Prairie and Atlantic Provinces. However, this relationship is not statistically significant. Possible explanations behind this reversal of relationship could be due to several factors including that with time better opportunities may present themselves for integrating into the labour market compared to when they just landed in 2001. It could also be because, with time, immigrants may learn to better adjust their living costs and lifestyles with their income levels, or overcome higher initial costs of resettlement.

\subsubsection{Effect of Ties with Home Country and Host Country (Canada) on Remitting Patterns}

The two variables that this section discusses measure aspects of immigrants' behaviour regarding links to their home country and Canada. The first variable, invested abroad, captures the remitting behaviours of those recent immigrants who have investments abroad. The results in Table 2.2 indicate that recent immigrants with investments abroad remit significantly more (C\$149-C\$197 within two years of landing and $\mathrm{C} \$ 153-\mathrm{C} \$ 171$ within four years of landing) than those who do not have any similar investments, after controlling for income. Immigrants who invest in their home country the likely destination of external investments made by most immigrants (Ports \& Guarzino, 1991) - may be signaling a stronger tie with their home countries (Unheim \& Rowlands, 2012), and have incentives to remit to family members looking after these investments. 
The second variable, immigrant's membership in community group associated with his/her home country, explores the remitting patterns of immigrants who join a community group upon their arrival in Canada. Results in Table 2.2 indicate that for recent immigrants' memberships in community groups are associated with an increase in remittances being sent home. This relationship is statistically significant for wave 2 interviewees (those living in Canada for two years or less). However, although the coefficient remains positive the effect of this variable is not statistically significant for wave 3 interviewees. In other words, as immigrants spend more time in Canada their remittance patterns are not significantly influenced by their membership in community groups.

The estimation model also analyzed variables such as immigrants' association with their ethnic values, views on importance of learning and practicing the values and traditions associated with the Canadian culture. None of these variables appeared to have any significant impact on immigrants remitting behaviours. These results (not presented in the Table) indicate that respondents who claim that they feel it is important to maintain their ethnic identity in Canada exhibit similar remitting patterns as their counterparts who do not express similar views. Similarly, respondents' views on Canadian values or the related questions of integration to the Canadian society do not appear to have any strong effects on their remitting patterns. The effects of these variables could be taken as evidence supporting transnational theories of migration, where migrant's identity is not bifurcated between the host and the home country, rather it accommodates both. Similar results are reported in Unheim and Rowlands (2012).

\subsubsection{Regional Effects on Remittances Sent}

Results in Table 2.2 indicate that recent immigrants from all the regions (analyzed in this chapter) give more than those migrating to Canada from the base regions - U.S., 
U.K, Western and Southern Europe. The regional trends presented in the tables would therefore need to be interpreted as remitting trends in comparison to this base group of relatively higher income countries. The estimations indicate that recent immigrants to Canada arriving from developing and lower income regions (per United Nations country classification) such as North Africa, West Africa, East Africa, Central Africa, Eastern Europe, South Asia, Southeast Asia and Caribbean, remit significantly more than those from the base regions, though to varying degrees. This relationship holds true for both periods of time analyzed in this chapter (within two years after arrival and within four years after arrival). For example, compared to the base region immigrants, an immigrant from Eastern Europe remits between $\mathrm{C} \$ 84-\mathrm{C} \$ 119$ more monthly, immigrants arriving from West Africa remit C\$119-C $\$ 165$ more monthly, those from Southeast Asia remit between C \$150-C $\$ 292$ more monthly and those from the Caribbean remit between C $\$ 156-\mathrm{C} \$ 282$ more monthly. Appendix A.7 provides a breakdown of the various regions by countries.

This remitting tendency is consistent with the factors that these immigrants have identified as motivating them to immigrate in the first place. An overwhelming majority of the immigrants in the LSIC survey identified improving the future of their family as an essential element motivating them to immigrate to Canada. Most of these migrants have ties with their families left behind who benefit from the remittances being sent by the immigrants. This finding is also consistent with the NELM theory that contends that migration decisions are made by families (households) and not by individual migrants (Massey et al., 1993).

An interesting point to note about the coefficients of the region of origin variables is that, for the most part, the region effect declines from wave 2 to wave 3 , that is, the higher remittance levels tend to decline with time. This decline could also be because 
remittances from the base-region migrants increases, or that more of the variation is being explained by the other explanatory variables in the model. This declining trend is also observed in the weighted means between the two waves: the average monthly remittances decline from $\mathrm{C} \$ 150$ (wave 2) to $\mathrm{C} \$ 141$ (wave 3).

The causes of variations in remitting tendencies within the regions can be explained by several factors including differing exchange rates, differing home county income levels within each region, ease of remittance transfer, proximity and ease of travel to and from Canada. Theories of transnationalism suggest that it is difficult to generalize the behaviour across immigrants from different countries within the same region (Kelly, 2003). Additionally, there may be other nuanced social factors influencing the regional differences in the volumes of remittances being sent. For instance, immigrants living in Canada who are planning to sponsor their left-behind family members are most likely trying to save money for that purpose and as a result may remit less than those who do not have the same immediate intentions. Exploration of the role of these more nuanced factors could be an interesting area of future research. The data collected in the LSIC survey limits analysis of this sort.

\subsection{Sensitivity Analysis}

To test the robustness of the results observed in Table 2.2, this chapter ran the same model restricting the sample to single-adult households only (Appendix A.5) and respondents who identified themselves as either the principal applicant or spouse of the principal applicant (Appendix A.6). Estimation results in Appendices A.5 and A.6 indicate that there are no significant qualitative differences owing to the differences in samples. Regardless of the sample, immigrants respond by remitting significantly more in the aftermath of natural disasters affecting their home countries. 
The three-natural disaster related coefficients (number killed by disaster, people affected by disaster and damages caused by disaster) in Appendices A.5 and A.6 are all statistically significant at the 1 per cent level and their magnitudes vary slightly depending on which disaster threshold is being used (however, Appendices A.5 and A.6 only presents results for threshold 1: when damages are worth $\mathrm{C} \$ 1$ million or more). Although the significance as well as the direction of the effect remains the same, the absolute value of the coefficient estimate is slightly lower for single adult households. For instance, focusing on the response of single adults during wave 2, the chapter concludes that for disasters in which the total damages exceeded $\mathrm{C} \$ 1$ million, the average recent single adult immigrant to Canada remitted C $\$ 88$ more each month for every 10,000 fatalities, compared to $C \$ 126$ for the full sample. If instead the severity of the disaster is measured by the number of people being affected by it, remittances increase by $\mathrm{C} \$ 2.3$ per month for every 100,000 people affected (compared to $\mathrm{C} \$ 4.6$ ). Finally, when disaster severity is measured by the amount of damages it costs, these immigrants increase remittances by $\mathrm{C} \$ 4.4$ (instead of $\mathrm{C} \$ 6.7)$ per month for every $\mathrm{C} \$ 100,000$ worth of damage. The magnitude of the responses provided by the sample that included only principal applicant or their spouse is more aligned with the magnitude reported under the main table (Table 2.2). The responses from this latter group (for wave 2) is C $\$ 135$ more remittances for every 10,000 fatalities, $\mathrm{C} \$ 5.1$ more for every 100,000 people affected, and $\mathrm{C} \$ 6$ more for every $\mathrm{C} \$ 100,000$ worth of damages.

In relation to the influence of immigrants' households, as well as personal characteristics on their remitting patterns, both these samples confirm the results discussed earlier in this chapter. The only exception is noted for the single adult households when they are a member of a community group. Similar to the results in Table 2.2 (discussed in 
earlier section), for this sample, memberships in community groups were associated with an increase in remittances being sent home. However, unlike the full sample size where this relationship is only statistically significant for those who have been living in Canada for about two years, this group indicates that the relationship holds true past the two-year mark.

\subsection{Conclusion}

Using data collected from immigrants shortly after they arrived in Canada in the period from October 2000 to September 2001 (LSIC wave 2 and wave 3 surveys), and the data on natural disasters from the International Emergency Disasters Database (EM-DAT), this research is one of the first studies examining the responsiveness of remittances sent by Canadian immigrants in the aftermath of natural disasters affecting their countries of origin.

The empirical results of this study indicate that recent immigrants to Canada remit significantly more in the aftermath of natural disasters affecting their home countries. The study focused on natural disasters that were particularly severe in nature. For the purpose of this chapter, the severity was defined as those disasters that either caused more than $\mathrm{C} \$ 1$ million in total damages, or affected more that 5 million people, or killed more than 15,000 people in the immigrants' countries or origin. Focusing on severe disasters meant a higher likelihood that these disasters in the countries of origin would, in fact, affect a Canadian immigrant's family in his/her home country, and in turn will influence the remitting behaviour of the recent immigrant.

Consistent with the NELM theoretical framework, this chapter examined remitting behaviour from a household perspective, thus, including both individual immigrant and their household characteristics as explanatory variables of remitting patterns. The large sample empirical results conformed very well to existing theoretical expectations. There 
are numerous demographic and household characteristics that determine how much remittances immigrants send home. There is a strong association between an immigrant's household incomes in Canada and how much they remit to their families abroad. The higher the household incomes, the more they will remit. The decision on how much to remit is also strongly influenced by the size of one's immigrating unit. The more household members the immigrant has with him/her in Canada, the less he/she will remit. The more jobs the immigrant holds, the more she/he will remit (until it peaks around 4 jobs, after which remittances decline).

An immigrant's individual characteristics such as age also conforms with the general expectation that, as age increases, immigrants remit more until they reach a certain age (early 40s), after which they remit at a decreasing rate. The study also found that among recent Canadian immigrants, males remit significantly more than their female counterparts and that marital status does not play a crucial role in influencing remitting patterns. As discussed in the chapter, empirical findings, particularly the influence of migrant's sex on remitting trends, need to be interpreted with caution because it does not take into consideration complex social factors, such as the underlying gender relationships within the immigrants' households, which may tell us a more nuanced narrative.

The study findings also reveal that recent immigrants' levels of education do not significantly influence their remitting tendencies. However, with the availability of future data, it would be interesting to explore if this is the case for immigrants who have either lived in Canada for longer periods of time (more than 5 years) or those who arrived in Canada before 2001 (the study sample of this chapter came to Canada in 2001).

The estimations indicate that the administrative category under which the immigrants entered Canada also has an influence on remitting patterns. Compared to the 
base group of immigrants (skilled workers, provincial nominees and independent immigrants), refugees remitted significantly less for the two-time periods examined in this chapter. Business class immigrants start remitting less than the base group after 2 to 4 years of being in Canada.

Immigrants' location of residence in Canada also plays a role in determining how much they remit. Shortly after arrival, immigrants living in Ontario, Quebec and British Columbia remit less per migrant compared to those who located in other provinces in Canada. However, this effect dissipates with time as immigrants better adapt to their surroundings and/or integrate into the labour market.

Finally, recent immigrants from lower income regions gave significantly more than those immigrating to Canada from the US, the UK, Western and Southern Europe.

While this chapter sheds light onto some interesting remitting patterns of recent immigrants, particularly in the aftermath of natural disasters, it is important to recognize that these conclusions are based on survey responses from immigrants who have been living in Canada for less than two years and between two to four years. Hence, without further data analysis, it would be difficult to ascertain if the patterns observed for recent immigrants would be attributable to earlier cohorts of immigrants (arriving in Canada before 2001) or if it would remain the same as immigrants become more settled in Canada (e.g., 10 years after arrival). Furthermore, the empirical analysis presented here is based on experiences of Canadian immigrants. While the findings of this chapter are generally consistent with both the NELM theoretical framework, as well as the existing remittance literature, there may be other factors specific to the host country that may affect an immigrant's remitting pattern. For instance, there may be differences due to migrant selfselection or the rules of the host and destination country regarding which category of 
migrants will be admitted into the country. However, while much work remains, this chapter provides a valuable step in understanding general remitting behaviour as well as how this behaviour changes in response to natural disasters affecting the immigrants' countries of origin. 


\section{Appendix A}

\section{A.1 Details of Disasters included under each Threshold for Wave 2 and Wave 3}

Wave 2: Disasters where Total Damages $\geq$ C\$1 million

\begin{tabular}{|c|c|c|c|c|c|c|c|c|c|}
\hline Year & $\begin{array}{c}\text { Disaster } \\
\text { Group }\end{array}$ & $\begin{array}{c}\text { Disaster } \\
\text { Type }\end{array}$ & Country & $\begin{array}{c}\text { Start } \\
\text { Year }\end{array}$ & $\begin{array}{c}\text { Start } \\
\text { Month }\end{array}$ & $\begin{array}{c}\text { End } \\
\text { Month }\end{array}$ & $\begin{array}{c}\text { Number } \\
\text { Killed }\end{array}$ & $\begin{array}{c}\text { Total } \\
\text { Affected } \\
\text { Damages } \\
\text { (C\$) }\end{array}$ \\
\hline 2003 & Natural & Earthquake & Algeria & 2003 & 5 & 5 & 2,266 & 210,261 & $5,000,000$ \\
\hline 2003 & Natural & Flood & Argentina & 2003 & 4 & 5 & 23 & 160,000 & $1,028,210$ \\
\hline 2001 & Natural & Storm & China & 2001 & 7 & 7 & 33 & $14,998,298$ & $2,743,000$ \\
\hline 2002 & Natural & Drought & China & 2002 & 6 & 10 & 0 & $3,660,000$ & $1,210,000$ \\
\hline 2002 & Natural & Flood & China & 2002 & 6 & 6 & 793 & $80,035,257$ & $3,100,000$ \\
\hline 2003 & Natural & Flood & China & 2003 & 6 & 7 & 430 & $150,146,000$ & $7,890,000$ \\
\hline 2003 & Natural & Flood & China & 2003 & 7 & 8 & 30 & $1,200,000$ & $4,830,000$ \\
\hline 2003 & Natural & Flood & China & 2003 & 8 & 11 & 123 & 200,000 & $2,440,000$ \\
\hline 2002 & Natural & Storm & Korea & 2002 & 8 & 9 & 184 & 88,625 & $4,200,000$ \\
\hline 2003 & Natural & Storm & Korea & 2003 & 9 & 9 & 130 & 80,000 & $4,500,000$ \\
\hline
\end{tabular}

Wave 2: Disasters where Number of Fatalities $\geq \mathbf{1 5 , 0 0 0}$

\begin{tabular}{|c|c|c|c|c|c|c|c|c|c|}
\hline Year & $\begin{array}{c}\text { Disaster } \\
\text { Group }\end{array}$ & $\begin{array}{c}\text { Disaster } \\
\text { Type }\end{array}$ & Country & $\begin{array}{c}\text { Start } \\
\text { Year }\end{array}$ & $\begin{array}{c}\text { Start } \\
\text { Month }\end{array}$ & $\begin{array}{c}\text { End } \\
\text { Month }\end{array}$ & $\begin{array}{c}\text { Number } \\
\text { Killed }\end{array}$ & $\begin{array}{c}\text { Total } \\
\text { Affected } \\
\text { Damages } \\
\text { (C\$) }\end{array}$ \\
\hline 2001 & Natural & Earthquake & India & 2001 & 1 & 1 & 20,005 & $6,321,812$ & $2,623,000$ \\
\hline 2003 & Natural & Earthquake & Iran & 2003 & 12 & 12 & 26,796 & 267,628 & 500,000 \\
\hline
\end{tabular}

Wave 2: Disasters where Number of People Affected $\geq 5$ million

\begin{tabular}{|c|c|c|c|c|c|c|c|c|c|}
\hline Year & $\begin{array}{c}\text { Disaster } \\
\text { Group }\end{array}$ & $\begin{array}{c}\text { Disaster } \\
\text { Type }\end{array}$ & Country & $\begin{array}{c}\text { Start } \\
\text { Year }\end{array}$ & $\begin{array}{c}\text { Start } \\
\text { Month }\end{array}$ & $\begin{array}{c}\text { End } \\
\text { Month }\end{array}$ & $\begin{array}{c}\text { Number } \\
\text { Killed }\end{array}$ & $\begin{array}{c}\text { Total } \\
\text { Affected } \\
\text { Damages } \\
(\mathbf{C} \mathbf{)}\end{array}$ \\
\hline 2001 & Natural & Drought & China & 2001 & 3 & 0 & 0 & $15,800,000$ & $12,890,000$ \\
\hline 2002 & Natural & Storm & China & 2002 & 3 & 3 & 0 & $100,000,000$ & $10,245,000$ \\
\hline 2002 & Natural & Drought & China & 2002 & 4 & 0 & 0 & $60,000,000$ & - \\
\hline 2002 & Natural & Flood & China & 2002 & 5 & 5 & 0 & $20,000,000$ & $1,943,000$ \\
\hline 2002 & Natural & Flood & China & 2002 & 6 & 6 & 793 & $80,035,257$ & $3,100,000$ \\
\hline 2002 & Natural & Flood & China & 2002 & 8 & 8 & 165 & $6,340,000$ & $5,400,000$ \\
\hline 2002 & Natural & Flood & China & 2002 & 8 & 8 & 16 & $5,250,000$ & - \\
\hline 2002 & Natural & Storm & China & 2002 & 9 & 9 & 26 & $7,000,040$ & - \\
\hline 2003 & Natural & Drought & China & 2003 & 1 & 1 & 0 & $48,000,000$ & - \\
\hline 2003 & Natural & Flood & China & 2003 & 6 & 7 & 430 & $150,146,000$ & $7,890,000$ \\
\hline 2003 & Natural & Storm & China & 2003 & 7 & 7 & 20 & $7,400,020$ & 100,000 \\
\hline 2004 & Natural & Flood & China & 2004 & 7 & 7 & 133 & $6,652,026$ & $1,100,000$ \\
\hline 2004 & Natural & Storm & China & 2004 & 8 & 8 & 188 & $9,062,000$ & $2,190,000$ \\
\hline 2005 & Natural & Storm & China & 2005 & 3 & 3 & 36 & $8,000,000$ & $1,300,000$ \\
\hline 2005 & Natural & Flood & China & 2005 & 6 & 6 & 235 & $16,700,000$ & $2,160,000$ \\
\hline
\end{tabular}




\begin{tabular}{|c|c|c|c|c|c|c|c|c|c|}
\hline Year & $\begin{array}{c}\text { Disaster } \\
\text { Group }\end{array}$ & $\begin{array}{c}\text { Disaster } \\
\text { Type }\end{array}$ & Country & $\begin{array}{c}\text { Start } \\
\text { Year }\end{array}$ & $\begin{array}{c}\text { Start } \\
\text { Month }\end{array}$ & $\begin{array}{c}\text { End } \\
\text { Month }\end{array}$ & $\begin{array}{c}\text { Number } \\
\text { Killed }\end{array}$ & $\begin{array}{c}\text { Total } \\
\text { Affected }\end{array}$ & $\begin{array}{c}\text { Total } \\
\text { Damages } \\
\text { (C\$) }\end{array}$ \\
\hline 2005 & Natural & Flood & China & 2005 & 6 & 7 & 58 & $11,230,230$ & 607,000 \\
\hline 2005 & Natural & Drought & China & 2005 & 7 & 0 & 0 & $7,600,000$ & - \\
\hline 2005 & Natural & Storm & China & 2005 & 9 & 9 & 159 & $19,624,000$ & $1,900,000$ \\
\hline 2005 & Natural & Storm & China & 2005 & 9 & 9 & 25 & $5,719,000$ & $1,040,000$ \\
\hline 2001 & Natural & Storm & Cuba & 2001 & 11 & 11 & 5 & $5,900,012$ & 100,000 \\
\hline 2003 & Natural & Drought & Ethiopia & 2003 & 0 & 0 & 0 & $12,600,000$ & - \\
\hline 2001 & Natural & Earthquake & India & 2001 & 1 & 1 & 20,005 & $6,321,812$ & $2,623,000$ \\
\hline 2001 & Natural & Flood & India & 2001 & 7 & 7 & 100 & $9,670,000$ & 90,000 \\
\hline 2001 & Natural & Flood & India & 2001 & 8 & 8 & 158 & $7,000,000$ & 26,000 \\
\hline 2002 & Natural & Flood & India & 2002 & 6 & 8 & 549 & $42,000,000$ & 30,772 \\
\hline 2002 & Natural & Drought & India & 2002 & 7 & 0 & 0 & $300,000,000$ & 910,722 \\
\hline 2001 & Natural & Drought & Zimbabwe & 2001 & 3 & 0 & 0 & $6,000,000$ & - \\
\hline
\end{tabular}

Wave 3: Disasters where Total Damages $\geq$ C $\$ 1$ million

\begin{tabular}{|c|c|c|c|c|c|c|c|c|c|}
\hline Year & $\begin{array}{c}\text { Disaster } \\
\text { Group }\end{array}$ & $\begin{array}{l}\text { Disaster } \\
\text { Type }\end{array}$ & Country & $\begin{array}{l}\text { Start } \\
\text { Year }\end{array}$ & $\begin{array}{l}\text { Start } \\
\text { Month }\end{array}$ & $\begin{array}{c}\text { End } \\
\text { Month }\end{array}$ & $\begin{array}{c}\text { Number } \\
\text { Killed }\end{array}$ & $\begin{array}{c}\text { Total } \\
\text { Affected }\end{array}$ & $\begin{array}{c}\text { Total } \\
\text { Damages } \\
\text { (C\$) }\end{array}$ \\
\hline 2003 & Natural & Earthquake & Algeria & 2003 & 5 & 5 & 2,266 & 210,261 & $5,000,000$ \\
\hline 2003 & Natural & Flood & Argentina & 2003 & 4 & 5 & 23 & 160,000 & $1,028,210$ \\
\hline 2001 & Natural & Storm & China & 2001 & 7 & 7 & 33 & $14,998,298$ & $2,743,000$ \\
\hline 2002 & Natural & Drought & China & 2002 & 6 & 10 & 0 & $3,660,000$ & $1,210,000$ \\
\hline 2002 & Natural & Flood & China & 2002 & 6 & 6 & 793 & $80,035,257$ & $3,100,000$ \\
\hline 2003 & Natural & Flood & China & 2003 & 6 & 7 & 430 & $150,146,000$ & $7,890,000$ \\
\hline 2003 & Natural & Flood & China & 2003 & 7 & 8 & 30 & $1,200,000$ & $4,830,000$ \\
\hline 2003 & Natural & Flood & China & 2003 & 8 & 11 & 123 & 200,000 & $2,440,000$ \\
\hline 2004 & Natural & Flood & Bangladesh & 2004 & 6 & 8 & 730 & $36,000,000$ & $2,200,000$ \\
\hline 2004 & Natural & Drought & Brazil & 2004 & 12 & 3 & 0 & - & $1,650,000$ \\
\hline 2003 & Natural & Flood & China & 2003 & 7 & 8 & 30 & $1,200,000$ & $4,830,000$ \\
\hline 2003 & Natural & Flood & China & 2003 & 8 & 11 & 123 & 200,000 & $2,440,000$ \\
\hline 2004 & Natural & Flood & China & 2004 & 7 & 7 & 133 & $33,652,026$ & $1,100,000$ \\
\hline 2004 & Natural & Storm & China & 2004 & 8 & 8 & 188 & $9,062,000$ & $2,190,000$ \\
\hline 2004 & Natural & Storm & Cuba & 2004 & 8 & 8 & 4 & 244,005 & $1,000,000$ \\
\hline 2004 & Natural & Flood & India & 2004 & 6 & 8 & 900 & $33,000,000$ & $2,500,000$ \\
\hline 2004 & Natural & Earthquake & India & 2004 & 12 & 12 & 16,389 & 654,512 & $1,022,800$ \\
\hline 2005 & Natural & Flood & India & 2005 & 7 & 8 & 1,200 & $20,000,055$ & $3,330,000$ \\
\hline 2005 & Natural & Flood & India & 2005 & 6 & 7 & 239 & 405,000 & $2,300,000$ \\
\hline 2005 & Natural & Earthquake & India & 2005 & 10 & 10 & 1,309 & 156,622 & $1,000,000$ \\
\hline 2004 & Natural & Earthquake & Indonesia & 2004 & 12 & 12 & 16,5708 & 532,898 & $4,451,600$ \\
\hline 2004 & Natural & Flood & Japan & 2004 & 7 & 7 & 21 & 25,807 & $1,950,000$ \\
\hline 2004 & Natural & Storm & Japan & 2004 & 8 & 8 & 14 & 180,050 & $2,000,000$ \\
\hline 2004 & Natural & Storm & Japan & 2004 & 9 & 9 & 41 & 40,900 & $9,000,000$ \\
\hline
\end{tabular}




\begin{tabular}{|c|c|c|c|c|c|c|c|c|c|}
\hline Year & $\begin{array}{c}\text { Disaster } \\
\text { Group }\end{array}$ & $\begin{array}{c}\text { Disaster } \\
\text { Type }\end{array}$ & Country & $\begin{array}{c}\text { Start } \\
\text { Year }\end{array}$ & $\begin{array}{c}\text { Start } \\
\text { Month }\end{array}$ & $\begin{array}{c}\text { End } \\
\text { Month }\end{array}$ & $\begin{array}{c}\text { Number } \\
\text { Killed }\end{array}$ & $\begin{array}{c}\text { Total } \\
\text { Affected }\end{array}$ & $\begin{array}{c}\text { Total } \\
\text { Damages } \\
\text { (C\$) }\end{array}$ \\
\hline 2004 & Natural & Storm & Japan & 2004 & 10 & 10 & 89 & 84,792 & $2,300,000$ \\
\hline 2004 & Natural & Earthquake & Japan & 2004 & 10 & 10 & 40 & 62,183 & $28,000,000$ \\
\hline 2005 & Natural & Storm & Japan & 2005 & 9 & 9 & 32 & 270,140 & $1,000,000$ \\
\hline 2005 & Natural & Storm & Mexico & 2005 & 10 & 10 & 36 & $1,954,571$ & $2,500,000$ \\
\hline 2005 & Natural & Storm & Mexico & 2005 & 10 & 10 & 7 & $1,000,000$ & $5,000,000$ \\
\hline 2005 & Natural & Earthquake & Pakistan & 2005 & 10 & 10 & 73,338 & $5,128,309$ & $5,200,000$ \\
\hline 2004 & Natural & Earthquake & Sri Lanka & 2004 & 12 & 12 & 35,399 & $1,019,306$ & $1,316,500$ \\
\hline 2004 & Natural & Earthquake & Thailand & 2004 & 12 & 12 & 8,345 & 67,007 & $1,200,000$ \\
\hline
\end{tabular}

Wave 3: Disasters where Number of Fatalities $\geq \mathbf{1 5 , 0 0 0}$

\begin{tabular}{|c|c|c|c|c|c|c|c|c|c|}
\hline Year & $\begin{array}{c}\text { Disaster } \\
\text { Group }\end{array}$ & $\begin{array}{c}\text { Disaster } \\
\text { Type }\end{array}$ & Country & $\begin{array}{c}\text { Start } \\
\text { Year }\end{array}$ & $\begin{array}{c}\text { Start } \\
\text { Month }\end{array}$ & $\begin{array}{c}\text { End } \\
\text { Month }\end{array}$ & $\begin{array}{c}\text { Number } \\
\text { Killed }\end{array}$ & $\begin{array}{c}\text { Total } \\
\text { Affected }\end{array}$ & $\begin{array}{c}\text { Total } \\
\text { Damages } \\
\text { (C\$) }\end{array}$ \\
\hline 2004 & Natural & Earthquake & India & 2004 & 12 & 12 & 16,389 & 654,512 & $1,022,800$ \\
\hline 2004 & Natural & Earthquake & Indonesia & 2004 & 12 & 12 & 16,5708 & 532,898 & $4,451,600$ \\
\hline 2003 & Natural & Earthquake & Iran & 2003 & 12 & 12 & 26,796 & 267,628 & 500,000 \\
\hline 2005 & Natural & Earthquake & Pakistan & 2005 & 10 & 10 & 73,338 & $5,128,309$ & $5,200,000$ \\
\hline 2004 & Natural & Earthquake & Sri Lanka & 2004 & 12 & 12 & 35,399 & $1,019,306$ & $1,316,500$ \\
\hline
\end{tabular}

Wave 3: Disasters where Number of People Affected $\geq 5$ million

\begin{tabular}{|c|c|c|c|c|c|c|c|c|c|}
\hline Year & $\begin{array}{c}\text { Disaster } \\
\text { Group }\end{array}$ & $\begin{array}{c}\text { Disaster } \\
\text { Type }\end{array}$ & Country & $\begin{array}{c}\text { Start } \\
\text { Year }\end{array}$ & $\begin{array}{c}\text { Start } \\
\text { Month }\end{array}$ & $\begin{array}{c}\text { End } \\
\text { Month }\end{array}$ & $\begin{array}{c}\text { Number } \\
\text { Killed }\end{array}$ & $\begin{array}{c}\text { Total } \\
\text { Affected }\end{array}$ & $\begin{array}{c}\text { Total } \\
\text { Damages } \\
\text { (C\$) }\end{array}$ \\
\hline 2001 & Natural & Drought & China & 2001 & 3 & 0 & 0 & $15,800,000$ & - \\
\hline 2002 & Natural & Storm & China & 2002 & 3 & 3 & 0 & $100,000,000$ & - \\
\hline 2002 & Natural & Drought & China & 2002 & 4 & 0 & 0 & $60,000,000$ & - \\
\hline 2002 & Natural & Flood & China & 2002 & 5 & 5 & 0 & $20,000,000$ & 943,000 \\
\hline 2002 & Natural & Flood & China & 2002 & 6 & 6 & 793 & $80,035,257$ & $3,100,000$ \\
\hline 2002 & Natural & Flood & China & 2002 & 8 & 8 & 165 & $6,340,000$ & 540,000 \\
\hline 2002 & Natural & Flood & China & 2002 & 8 & 8 & 16 & $5,250,000$ & - \\
\hline 2002 & Natural & Storm & China & 2002 & 9 & 9 & 26 & $7,000,040$ & 100,000 \\
\hline 2003 & Natural & Drought & China & 2003 & 1 & 1 & 0 & $48,000,000$ & - \\
\hline 2003 & Natural & Flood & China & 2003 & 6 & 7 & 430 & $150,146,000$ & $7,890,000$ \\
\hline 2003 & Natural & Storm & China & 2003 & 7 & 7 & 20 & $7,400,020$ & 100,000 \\
\hline 2004 & Natural & Flood & China & 2004 & 7 & 7 & 133 & $33,652,026$ & $1,100,000$ \\
\hline 2004 & Natural & Storm & China & 2004 & 8 & 8 & 188 & $9,062,000$ & $2,190,000$ \\
\hline 2005 & Natural & Storm & China & 2005 & 3 & 3 & 36 & $8,000,000$ & 300,000 \\
\hline 2005 & Natural & Flood & China & 2005 & 6 & 6 & 235 & $16,700,000$ & $2,160,000$ \\
\hline 2005 & Natural & Flood & China & 2005 & 6 & 7 & 58 & $11,230,230$ & 607,000 \\
\hline 2005 & Natural & Drought & China & 2005 & 7 & 0 & 0 & $7,600,000$ & - \\
\hline 2005 & Natural & Storm & China & 2005 & 9 & 9 & 159 & $19,624,000$ & $1,900,000$ \\
\hline 2005 & Natural & Storm & China & 2005 & 9 & 9 & 25 & $5,719,000$ & $1,040,000$ \\
\hline
\end{tabular}




\begin{tabular}{|c|c|c|c|c|c|c|c|c|c|}
\hline Year & $\begin{array}{c}\text { Disaster } \\
\text { Group }\end{array}$ & $\begin{array}{c}\text { Disaster } \\
\text { Type }\end{array}$ & Country & $\begin{array}{c}\text { Start } \\
\text { Year }\end{array}$ & $\begin{array}{c}\text { Start } \\
\text { Month }\end{array}$ & $\begin{array}{c}\text { End } \\
\text { Month }\end{array}$ & $\begin{array}{c}\text { Number } \\
\text { Killed }\end{array}$ & $\begin{array}{c}\text { Total } \\
\text { Affected } \\
\text { Damages } \\
\text { (C\$) }\end{array}$ \\
\hline 2001 & Natural & Storm & Cuba & 2001 & 11 & 11 & 5 & $5,900,012$ & 100,000 \\
\hline 2003 & Natural & Drought & Ethiopia & 2003 & 0 & 0 & 0 & $12,600,000$ & - \\
\hline 2001 & Natural & Earthquake & India & 2001 & 1 & 1 & 20,005 & $6,321,812$ & $2,623,000$ \\
\hline 2001 & Natural & Flood & India & 2001 & 7 & 7 & 100 & $9,670,000$ & 90,000 \\
\hline 2001 & Natural & Flood & India & 2001 & 8 & 8 & 158 & $7,000,000$ & 26,000 \\
\hline 2002 & Natural & Flood & India & 2002 & 6 & 8 & 549 & $42,000,000$ & 30,772 \\
\hline 2002 & Natural & Drought & India & 2002 & 7 & 0 & 0 & $300,000,000$ & 910,722 \\
\hline 2002 & Natural & Drought & Thailand & 2002 & 2 & 0 & 0 & $5,000,000$ & 2,300 \\
\hline 2001 & Natural & Drought & Zimbabwe & 2001 & 3 & 0 & 0 & $6,000,000$ & - \\
\hline
\end{tabular}




\section{A.2 Variable Definitions}

\begin{tabular}{|c|c|c|}
\hline \multicolumn{3}{|c|}{ Variable Definitions: LSIC Database } \\
\hline Variable & $\begin{array}{l}\text { Definition } \\
\end{array}$ & LSIC Source \\
\hline Monthly Remittances & $\begin{array}{l}\text { Calculated by dividing the total amount of money } \\
\text { immigrants sent home by the number of months that } \\
\text { elapsed between wave } 1 \text { and wave } 2 \text { interviews and } \\
\text { wave } 2 \text { and wave } 3 \text { interviews respectively. }\end{array}$ & IN2Q098 \\
\hline Immigrating Unit Size & $\begin{array}{l}\text { The number of family members who immigrated } \\
\text { with the survey respondent }\end{array}$ & LR1D048 \\
\hline $\begin{array}{l}\text { Total Household } \\
\text { Income }\end{array}$ & $\begin{array}{l}\text { Total gross income received from all sources by the } \\
\text { respondent's economic family (in Canada) in the } \\
\text { past } 12 \text { months prior to the survey date }\end{array}$ & IN2D069X \\
\hline Number of Jobs & $\begin{array}{l}\text { Number of jobs held by the survey respondent since } \\
\text { arrival in Canada }\end{array}$ & EM2L403 \\
\hline Invested Abroad & $\begin{array}{l}\text { Dummy variable coded as } 1 \text { if the respondent send } \\
\text { money outside Canada for investment purposes; } 0 \\
\text { otherwise }\end{array}$ & IN2Q060 \\
\hline Education & Respondent's years of formal education & ED1Q024 \\
\hline Married & $\begin{array}{l}\text { Dummy variable coded as } 1 \text { if the respondent is } \\
\text { married; } 0 \text { otherwise }\end{array}$ & \\
\hline Sex & $\begin{array}{l}\text { Dummy variable coded as } 1 \text { if the respondent is } \\
\text { male; } 0 \text { otherwise }\end{array}$ & LR1Q008 \\
\hline Age & Respondent's age & LR1D005 \\
\hline Family Class & $\begin{array}{l}\text { Dummy variable coded as } 1 \text { if the respondent } \\
\text { immigrated to Canada under the family class } \\
\text { category; } 0 \text { otherwise }\end{array}$ & LR1D011 \\
\hline Business Class & $\begin{array}{l}\text { Dummy variable coded as } 1 \text { if the respondent } \\
\text { immigrated to Canada under the business class } \\
\text { category; } 0 \text { otherwise }\end{array}$ & LR1D011 \\
\hline Refugee & $\begin{array}{l}\text { Dummy variable coded as } 1 \text { if the respondent } \\
\text { immigrated to Canada under the refugee category; } 0 \\
\text { otherwise }\end{array}$ & LR1D011 \\
\hline Member of a Group & $\begin{array}{l}\text { Dummy variable coded as } 1 \text { if the respondent is a } \\
\text { member of a community group or organization; } 0 \\
\text { otherwise }\end{array}$ & SI2Q042 \\
\hline Ethnic Values & $\begin{array}{l}\text { Dummy variable coded as } 1 \text { if the respondent } \\
\text { reports that carrying on his/her ethnic and cultural } \\
\text { values is either "important" or "very important"; } 0 \\
\text { otherwise }\end{array}$ & VA2Q004 \\
\hline Canadian Values & $\begin{array}{l}\text { Dummy variable coded as } 1 \text { if the respondent } \\
\text { reports that learning and practicing the values and } \\
\text { traditions of people in Canada is either "important" } \\
\text { or "very important"; } 0 \text { otherwise }\end{array}$ & VA2Q005 \\
\hline Ontario Resident & $\begin{array}{l}\text { Dummy variable coded as } 1 \text { if the respondent } \\
\text { resided in Ontario at the time of the survey; } 0 \\
\text { otherwise }\end{array}$ & CLA_Q01_2 \\
\hline Quebec Resident & $\begin{array}{l}\text { Dummy variable coded as } 1 \text { if the respondent } \\
\text { resided in Quebec at the time of the survey; } 0 \\
\text { otherwise }\end{array}$ & CLA_Q01_2 \\
\hline $\begin{array}{l}\text { British Columbia } \\
\text { Resident }\end{array}$ & $\begin{array}{l}\text { Dummy variable coded as } 1 \text { if the respondent } \\
\text { resided in British Columbia at the time of the } \\
\text { survey; } 0 \text { otherwise }\end{array}$ & CLA_Q01_2 \\
\hline
\end{tabular}




\begin{tabular}{|l|l|c|}
\hline Eastern Europe & $\begin{array}{l}\text { Dummy variable coded as 1 if the respondent's } \\
\text { region of origin is Eastern Europe; 0 otherwise }\end{array}$ & LR1G012 \\
\hline North Africa & $\begin{array}{l}\text { Dummy variable coded as 1 if the respondent's } \\
\text { region of origin is North Africa; 0 otherwise }\end{array}$ & LR1G012 \\
\hline West Africa & $\begin{array}{l}\text { Dummy variable coded as 1 if the respondent's } \\
\text { region of origin is West Africa; 0 otherwise }\end{array}$ & LR1G012 \\
\hline East Africa & $\begin{array}{l}\text { Dummy variable coded as 1 if the respondent's } \\
\text { region of origin is East Africa; 0 otherwise }\end{array}$ & LR1G012 \\
\hline Central Africa & $\begin{array}{l}\text { Dummy variable coded as 1 if the respondent's } \\
\text { region of origin is Central Africa; 0 otherwise }\end{array}$ & LR1G012 \\
\hline South Asia & $\begin{array}{l}\text { Dummy variable coded as 1 if the respondent's } \\
\text { region of origin is South Asia; 0 otherwise }\end{array}$ & LR1G012 \\
\hline Southeast Asia & $\begin{array}{l}\text { Dummy variable coded as 1 if the respondent's } \\
\text { region of origin is Southeast Asia; 0 otherwise }\end{array}$ & LR1G012 \\
\hline Caribbean & $\begin{array}{l}\text { Dummy variable coded as 1 if the respondent's } \\
\text { region of origin is Caribbean; 0 otherwise }\end{array}$ & LR1G012 \\
\hline South America & $\begin{array}{l}\text { Dummy variable coded as 1 if the respondent's } \\
\text { region of origin is South America; 0 otherwise }\end{array}$ & LR1G012 \\
\hline Central America & $\begin{array}{l}\text { Dummy variable coded as 1 if the respondent's } \\
\text { region of origin is Central America; 0 otherwise }\end{array}$ & LR1G012 \\
\hline
\end{tabular}

\begin{tabular}{|l|l|}
\hline \multicolumn{2}{|c|}{ Variable Definitions: EM-DAT Natural Disaster Database } \\
\hline \multicolumn{1}{|c|}{ Variable } & \multicolumn{1}{c|}{ Definition } \\
\hline Number Killed & Total number of people killed as a result of the disaster event \\
\hline Total Affected & Total number of people affected by the disaster event \\
\hline Total Damages & $\begin{array}{l}\text { Cost of estimated damages due to the disaster event in the year of } \\
\text { occurrence. Total damages in the database are in US dollars. However, } \\
\text { since the LSIC data is in Canadian dollars, all values were converted to } \\
\text { Canadian dollars (US } \$ 1 \text { = C } \$ 1.30 \text { average exchange rate for the survey } \\
\text { period). }\end{array}$ \\
\hline
\end{tabular}




\section{A.3 Tobit Estimations for Monthly Remittance Levels (T-statistics in brackets below the}

coefficient)

\begin{tabular}{|c|c|c|c|c|c|c|}
\hline \multirow[b]{2}{*}{ Variables } & \multicolumn{3}{|c|}{ Wave 2} & \multicolumn{3}{|c|}{ Wave 3} \\
\hline & \multicolumn{3}{|c|}{ Threshold: Total Affected $\geq \$ 5 M$} & \multicolumn{3}{|c|}{ Threshold: Total Affected $\geq \$ 5 M$} \\
\hline $\begin{array}{l}\text { Total Household Income } \\
\text { (in \$1000s) }\end{array}$ & $\begin{array}{r}2.07 * * * \\
(4.10)\end{array}$ & $\begin{array}{r}2.29 * * * \\
(4.05)\end{array}$ & $\begin{array}{r}2.54 * * * \\
(4.28)\end{array}$ & $\begin{array}{r}1.84 * * * \\
(7.71)\end{array}$ & $\begin{array}{r}1.89 * * * \\
(7.82)\end{array}$ & $\begin{array}{r}1.88 * * * \\
(7.80)\end{array}$ \\
\hline$\left(\right.$ Total Household Income) ${ }^{2}$ & & & & & & \\
\hline (in $\$ 1000000 s$ ) & $\begin{array}{r}-0.0014 * * \\
(-2.03)\end{array}$ & $\begin{array}{r}-0.0019 * * * \\
(-3.80)\end{array}$ & $\begin{array}{r}-0.0013 * * \\
(-2.32)\end{array}$ & $\begin{array}{r}-0.0012 * * * \\
(-4.78)\end{array}$ & $\begin{array}{r}-0.0012 * * * \\
(-4.72)\end{array}$ & $\begin{array}{r}-0.0013 * * * \\
(-4.73)\end{array}$ \\
\hline Number of Jobs & $\begin{array}{r}61.65 * * * \\
(3.44)\end{array}$ & $\begin{array}{r}62.25 * * * \\
(3.48)\end{array}$ & $\begin{array}{r}61.69 * * * \\
(3.35)\end{array}$ & $\begin{array}{r}33.67 * * * \\
(3.51)\end{array}$ & $\begin{array}{r}32.61 * * * \\
(3.39)\end{array}$ & $\begin{array}{r}32.58 * * * \\
(3.38)\end{array}$ \\
\hline (Number of Jobs) $^{2}$ & $\begin{array}{r}-7.56 * * \\
(-2.40)\end{array}$ & $\begin{array}{l}-7.6 * * \\
(-2.37)\end{array}$ & $\begin{array}{r}-7.05 * * \\
(-2.17)\end{array}$ & $\begin{array}{l}-2.68^{*} \\
(-1.94)\end{array}$ & $\begin{array}{r}-2.59 * * \\
(-2.25)\end{array}$ & $\begin{array}{l}-2.58^{*} \\
(-1.92)\end{array}$ \\
\hline Immigrating Unit Size & $\begin{array}{r}-30.81 * * * \\
(-4.20)\end{array}$ & $\begin{array}{r}-29.56 * * * \\
(-3.84)\end{array}$ & $\begin{array}{r}-36.54 * * * \\
(-4.42)\end{array}$ & $\begin{array}{r}-30.44 * * * \\
(-6.86)\end{array}$ & $\begin{array}{r}-27.63 * * * \\
(-6.66)\end{array}$ & $\begin{array}{r}-26.66 * * * \\
(-6.68)\end{array}$ \\
\hline Yrs of Formal Education & $\begin{array}{l}-12.68 \\
(-1.32)\end{array}$ & $\begin{array}{l}-10.36 \\
(-1.09)\end{array}$ & $\begin{array}{l}-13.73 \\
(-1.31)\end{array}$ & $\begin{array}{r}-11.08^{*} \\
(-1.78)\end{array}$ & $\begin{array}{r}-11.76^{*} \\
(-1.70)\end{array}$ & $\begin{array}{l}-11.7^{*} \\
(-1.75)\end{array}$ \\
\hline$\left(\right.$ Yrs of Formal Education) ${ }^{2}$ & $\begin{array}{r}0.2602 \\
(0.88)\end{array}$ & $\begin{array}{r}0.1872 \\
(0.63)\end{array}$ & $\begin{array}{r}0.2696 \\
(0.84)\end{array}$ & $\begin{array}{r}0.2312 \\
(1.09)\end{array}$ & $\begin{array}{r}0.266 \\
(1.25)\end{array}$ & $\begin{array}{r}0.2631 \\
(1.24)\end{array}$ \\
\hline Age & $\begin{array}{r}17.11 * * \\
(2.64)\end{array}$ & $\begin{array}{r}15.96^{* *} \\
(2.55)\end{array}$ & $\begin{array}{r}16.02 * * \\
(2.46)\end{array}$ & $\begin{array}{r}16.05 * * * \\
(4.41)\end{array}$ & $\begin{array}{r}16.01 * * * \\
(4.39)\end{array}$ & $\begin{array}{r}15.92 * * * \\
(4.38)\end{array}$ \\
\hline $\mathrm{Age}^{2}$ & $\begin{array}{r}-0.2037 * * \\
(-2.73)\end{array}$ & $\begin{array}{r}-0.1889 * * \\
(-2.66)\end{array}$ & $\begin{array}{r}-0.1969 * * \\
(-2.60)\end{array}$ & $\begin{array}{r}-0.1981 * * * \\
(-4.68)\end{array}$ & $\begin{array}{r}-0.1973 * * * \\
(-4.65)\end{array}$ & $\begin{array}{r}-0.1972 * * * \\
(-4.65)\end{array}$ \\
\hline Male & $\begin{array}{r}23.12 * * \\
(2.58)\end{array}$ & $\begin{array}{r}15.36 * * \\
(2.27)\end{array}$ & $\begin{array}{r}38.64 * * \\
(2.79)\end{array}$ & $\begin{array}{r}39.96 * * * \\
(3.72)\end{array}$ & $\begin{array}{r}40.57 * * * \\
(3.77)\end{array}$ & $\begin{array}{r}40.55 * * * \\
(3.77)\end{array}$ \\
\hline Married Immigrants & $\begin{array}{l}-30.33 \\
(-1.42)\end{array}$ & $\begin{array}{l}-21.64 \\
(-1.01)\end{array}$ & $\begin{array}{l}-30.84 \\
(-1.39)\end{array}$ & $\begin{array}{l}-23.23 \\
(-1.25)\end{array}$ & $\begin{array}{l}-19.23 \\
(-1.21)\end{array}$ & $\begin{array}{l}-19.74 \\
(-1.15)\end{array}$ \\
\hline Family Class Category & $\begin{array}{l}-20.05 \\
(-0.92)\end{array}$ & $\begin{array}{r}-14.8 \\
(-0.64)\end{array}$ & $\begin{array}{l}-32.65 \\
(-1.48)\end{array}$ & $\begin{array}{r}-15.13 \\
(-0.93)\end{array}$ & $\begin{array}{r}-11.17 \\
(-0.70)\end{array}$ & $\begin{array}{r}-11.82 \\
(-0.74)\end{array}$ \\
\hline Business Class Category & $\begin{array}{r}-90.07 \\
(-1.24)\end{array}$ & $\begin{array}{r}-113.19 \\
(-1.46)\end{array}$ & $\begin{array}{r}-88.13 \\
(-1.15)\end{array}$ & $\begin{array}{r}-156.39 * * * \\
(-4.22)\end{array}$ & $\begin{array}{r}-151.72 * * * \\
(-4.09)\end{array}$ & $\begin{array}{r}-152.21 * * * \\
(-4.11)\end{array}$ \\
\hline Refugee Class Catgory & $\begin{array}{r}-149.82 * * * \\
(-3.34)\end{array}$ & $\begin{array}{r}-131.81 * * * \\
(-3.23)\end{array}$ & $\begin{array}{r}-171.16^{* * *} \\
(-3.50)\end{array}$ & $\begin{array}{r}-90.15 * * * \\
(-4.52)\end{array}$ & $\begin{array}{r}-105.71 * * * \\
(-5.06)\end{array}$ & $\begin{array}{r}-103.96 * * * \\
(-5.00)\end{array}$ \\
\hline Ontario Resident & $\begin{array}{r}-95.82 * * * \\
(-2.98)\end{array}$ & $\begin{array}{r}-94.79 * * * \\
(-2.97)\end{array}$ & $\begin{array}{r}-102.79 * * * \\
(-3.01)\end{array}$ & $\begin{array}{r}18.91 \\
(1.11)\end{array}$ & $\begin{array}{r}19.77 \\
(1.16)\end{array}$ & $\begin{array}{r}19.66 \\
(1.16)\end{array}$ \\
\hline Quebec Resident & $\begin{array}{r}-94.38 * * * \\
(-3.94)\end{array}$ & $\begin{array}{r}-109.33 * * * \\
(-3.65)\end{array}$ & $\begin{array}{r}-106.96 * * * \\
(-4.03)\end{array}$ & $\begin{array}{l}-24.16 \\
(-1.50)\end{array}$ & $\begin{array}{l}-25.06 \\
(-1.55)\end{array}$ & $\begin{array}{l}-24.78 \\
(-1.40)\end{array}$ \\
\hline British Columbia Resident & $\begin{array}{r}-107.53 * * * \\
(-3.56)\end{array}$ & $\begin{array}{r}-99.26 * * * \\
(-3.50)\end{array}$ & $\begin{array}{r}-116.04 * * * \\
(-3.73)\end{array}$ & $\begin{array}{r}107.61 \\
(1.15)\end{array}$ & $\begin{array}{r}94.22 \\
(1.25)\end{array}$ & $\begin{array}{r}97.64 \\
(1.16)\end{array}$ \\
\hline Invested Abroad & $\begin{array}{r}155.21 * * \\
(2.51)\end{array}$ & $\begin{array}{r}162.89 * * \\
(2.21)\end{array}$ & $\begin{array}{r}183.33 * * \\
(2.31)\end{array}$ & $\begin{array}{r}181.58 * * * \\
(4.33)\end{array}$ & $\begin{array}{r}181.94 * * * \\
(4.32)\end{array}$ & $\begin{array}{r}181.87 * * * \\
(4.31)\end{array}$ \\
\hline Community Member & $\begin{array}{r}63.81 * * * \\
(3.88)\end{array}$ & $\begin{array}{r}66.92 * * * \\
(3.98)\end{array}$ & $\begin{array}{r}80.04 * * * \\
(3.89)\end{array}$ & $\begin{array}{r}10.16 \\
(0.56)\end{array}$ & $\begin{array}{r}10.91 \\
(0.60)\end{array}$ & $\begin{array}{r}10.94 \\
(0.60)\end{array}$ \\
\hline Eastern Europe & $\begin{array}{r}71.79 * \\
(1.92)\end{array}$ & $\begin{array}{r}46.55 * * \\
(2.20)\end{array}$ & $\begin{array}{r}98.12 * * \\
(2.23)\end{array}$ & $\begin{array}{r}22.33 * * \\
(2.28)\end{array}$ & $\begin{array}{r}43.71 * \\
(1.93)\end{array}$ & $\begin{array}{r}41.18^{*} \\
(1.95)\end{array}$ \\
\hline North Africa & $\begin{array}{r}89.91 * * * \\
(3.84)\end{array}$ & $\begin{array}{r}69.16^{* * *} \\
(3.82)\end{array}$ & $\begin{array}{r}73.69 * * * \\
(3.94)\end{array}$ & $\begin{array}{r}59.53 * * * \\
(4.47)\end{array}$ & $\begin{array}{r}69.08 * * * \\
(4.72)\end{array}$ & $\begin{array}{r}66.85 * * * \\
(4.69)\end{array}$ \\
\hline West Africa & $\begin{array}{r}102.89 * * * \\
(3.27)\end{array}$ & $\begin{array}{r}118.16 * * * \\
(3.16)\end{array}$ & $\begin{array}{r}119.61 * * * \\
(3.40)\end{array}$ & $\begin{array}{r}95.29 * * \\
(2.04)\end{array}$ & $\begin{array}{r}102.45 * * * \\
(3.59)\end{array}$ & $\begin{array}{r}96.85 * * \\
(2.50)\end{array}$ \\
\hline East Africa & $\begin{array}{r}100.66 * * \\
(2.80)\end{array}$ & $\begin{array}{r}111.99 * * \\
(2.30)\end{array}$ & $\begin{array}{r}113.28 * * \\
(2.30)\end{array}$ & $\begin{array}{r}71.01 * * \\
(2.51)\end{array}$ & $\begin{array}{r}66.43 * * \\
(2.57)\end{array}$ & $\begin{array}{r}60.38 * * \\
(2.76)\end{array}$ \\
\hline Central Africa & $\begin{array}{r}106.02 * * * \\
(3.26)\end{array}$ & $\begin{array}{r}98.75 * * \\
(2.55)\end{array}$ & $\begin{array}{r}112.86 * * * \\
(3.81)\end{array}$ & $\begin{array}{r}77.75 * * \\
(2.42)\end{array}$ & $\begin{array}{r}67.78 * * * \\
(3.99)\end{array}$ & $\begin{array}{r}63.42 * * * \\
(3.83)\end{array}$ \\
\hline South Asia & $\begin{array}{r}154.03 * * * \\
(2.84)\end{array}$ & $\begin{array}{r}153.72 * * * \\
(2.85)\end{array}$ & $\begin{array}{r}153.77 * * * \\
(2.98)\end{array}$ & $\begin{array}{r}101.32 * * \\
(2.39)\end{array}$ & $\begin{array}{r}102.95 * * \\
(2.39)\end{array}$ & $\begin{array}{r}111.45^{* *} \\
(2.39)\end{array}$ \\
\hline Southeast Asia & $\begin{array}{r}287.65 * * * \\
(3.99)\end{array}$ & $\begin{array}{r}264.06 * * * \\
(4.01)\end{array}$ & $\begin{array}{r}242.17 * * * \\
(4.11)\end{array}$ & $\begin{array}{r}174.62 * * * \\
(10.44)\end{array}$ & $\begin{array}{r}197.07 * * * \\
(10.23)\end{array}$ & $\begin{array}{r}194.59 * * * \\
(10.19)\end{array}$ \\
\hline Caribbean & $\begin{array}{r}255.56 * * * \\
(3.71)\end{array}$ & $\begin{array}{r}223.63 * * * \\
(3.69)\end{array}$ & $\begin{array}{r}211.85 * * * \\
(3.84)\end{array}$ & $\begin{array}{r}153.95 * * * \\
(5.20)\end{array}$ & $\begin{array}{r}175.35 * * * \\
(5.64)\end{array}$ & $\begin{array}{r}172.98 * * * \\
(5.58)\end{array}$ \\
\hline South America & $\begin{array}{r}127.08 * * * \\
(3.29)\end{array}$ & $\begin{array}{r}123.54 * * * \\
(3.09)\end{array}$ & $\begin{array}{r}152.25 * * * \\
(3.77)\end{array}$ & $\begin{array}{r}113.93 * * \\
(2.45)\end{array}$ & $\begin{array}{r}113.77 * * \\
(2.18)\end{array}$ & $\begin{array}{r}111.57 * * \\
(2.10)\end{array}$ \\
\hline Central America & $\begin{array}{r}113.45 * * \\
(2.43)\end{array}$ & $\begin{array}{r}101.95 * * \\
(2.50)\end{array}$ & $\begin{array}{r}119.23 * * \\
(2.58)\end{array}$ & $\begin{array}{r}53.65 * * * \\
(3.53)\end{array}$ & $\begin{array}{r}31.82 * * \\
(2.53)\end{array}$ & $\begin{array}{r}34.32 * * * \\
(3.50)\end{array}$ \\
\hline Number Killed by Disaster & $\begin{array}{r}0.0185 * * * \\
(4.30)\end{array}$ & & & $\begin{array}{r}0.0116 * * * \\
(2.96)\end{array}$ & & \\
\hline People Affected by Disaster & & $\begin{array}{r}0.000026^{* * * *} \\
(4.15)\end{array}$ & & & $\begin{array}{r}0.000028 * * * \\
(3.28)\end{array}$ & \\
\hline Total Damages (in CAD\$) & & & $\begin{array}{r}0.000096 * * * \\
(4.62)\end{array}$ & & & $\begin{array}{r}0.000045^{* * * *} \\
(3.09)\end{array}$ \\
\hline Constant & $\begin{array}{r}-735.32 * * * \\
(-3.31)\end{array}$ & $\begin{array}{r}-716.13 * * * \\
(-3.28)\end{array}$ & $\begin{array}{r}-755.23 * * * \\
(-3.35)\end{array}$ & $\begin{array}{r}-535.18 * * * \\
(-6.01)\end{array}$ & $\begin{array}{r}-557.19 * * * \\
(-6.23)\end{array}$ & $\begin{array}{r}-553.71 * * * \\
(-6.20)\end{array}$ \\
\hline Pseudo R2 & 0.055 & 0.0382 & 0.0454 & 0.0277 & 0.0282 & 0.0281 \\
\hline Observations & 7460 & 7460 & 7460 & 7460 & 7460 & 7460 \\
\hline
\end{tabular}


A.4 Tobit Estimations for Monthly Remittance Levels (T-statistics in brackets below the coefficient)

\begin{tabular}{|c|c|c|c|c|c|c|}
\hline & & Wave 2 & & & Wave 3 & \\
\hline Variables & Threshold & d: Total Killed & $d \geq 15000$ & Threshol & d: Total Killec & $\geq 15000$ \\
\hline $\begin{array}{l}\text { Total Household Income } \\
\text { (in } \$ 1000 \text { s) }\end{array}$ & $\begin{array}{r}2.04 * * * \\
(4.28)\end{array}$ & $\begin{array}{r}2.07 * * * \\
(4.28)\end{array}$ & $\begin{array}{r}2.04 * * * \\
(4.28)\end{array}$ & $\begin{array}{r}2.03 * * * \\
6.56\end{array}$ & $\begin{array}{r}2.08 * * * \\
(6.54)\end{array}$ & $\begin{array}{r}2.05 * * * \\
(6.55)\end{array}$ \\
\hline $\begin{array}{l}\text { (Total Household Income) }^{2} \\
\text { (in } \$ 1000000 \text { s) }\end{array}$ & $\begin{array}{r}-0.0015 * * \\
(-2.10)\end{array}$ & $\begin{array}{r}-0.0017 * * * \\
(-3.07)\end{array}$ & $\begin{array}{r}-0.0015^{* * *} \\
(-2.10)\end{array}$ & $\begin{array}{r}-0.0013 * * * \\
(-4.25)\end{array}$ & $\begin{array}{r}-0.0014 * * * \\
(-4.21)\end{array}$ & $\begin{array}{r}-0.0014 * * * \\
(-4.24)\end{array}$ \\
\hline Number of Jobs & $\begin{array}{r}77.32 * * * \\
(3.85)\end{array}$ & $\begin{array}{r}78.26 * * * \\
(3.86)\end{array}$ & $\begin{array}{r}77.349 * * * \\
(3.85)\end{array}$ & $\begin{array}{r}41.95 * * * \\
(3.60)\end{array}$ & $\begin{array}{r}45.57 * * * \\
(3.77)\end{array}$ & $\begin{array}{r}44.46 * * * \\
(3.70)\end{array}$ \\
\hline (Number of Jobs) $^{2}$ & $\begin{array}{r}-9.08 * * \\
(-2.64)\end{array}$ & $\begin{array}{r}-9.25 * * \\
(-2.67)\end{array}$ & $\begin{array}{r}-9.09 * * \\
(-2.64)\end{array}$ & $\begin{array}{r}-3.38 * * \\
(-2.07)\end{array}$ & $\begin{array}{r}-3.87 * * \\
(-2.28)\end{array}$ & $\begin{array}{r}-3.75 * * \\
(-2.23)\end{array}$ \\
\hline Immigrating Unit Size & $\begin{array}{r}-39.84 * * * \\
(-4.76)\end{array}$ & $\begin{array}{r}-39.91 * * * \\
(-4.76)\end{array}$ & $\begin{array}{r}-39.82 * * * \\
(-4.76)\end{array}$ & $\begin{array}{r}-32.38 * * * \\
(-5.88)\end{array}$ & $\begin{array}{r}-34.89 * * * \\
(-6.10)\end{array}$ & $\begin{array}{r}-33.93 * * * \\
(-6.03)\end{array}$ \\
\hline Yrs of Formal Education & $\begin{array}{l}-14.26 \\
(-1.41)\end{array}$ & $\begin{array}{l}-12.42 \\
(-1.21)\end{array}$ & $\begin{array}{l}-14.05 \\
(-1.39)\end{array}$ & $\begin{array}{r}-12.42 \\
(-1.58)\end{array}$ & $\begin{array}{l}-12.87 \\
(-1.50)\end{array}$ & $\begin{array}{l}-12.92 \\
(-1.18)\end{array}$ \\
\hline (Yrs of Formal Education) $^{2}$ & $\begin{array}{r}0.2645 \\
(0.85)\end{array}$ & $\begin{array}{r}0.1868 \\
(0.58)\end{array}$ & $\begin{array}{r}0.2558 \\
(0.82)\end{array}$ & $\begin{array}{r}0.2136 \\
(0.98)\end{array}$ & $\begin{array}{r}0.2293 \\
(1.02)\end{array}$ & $\begin{array}{r}0.2208 \\
(1.00)\end{array}$ \\
\hline Age & $\begin{array}{r}12.52 * * \\
(2.15)\end{array}$ & $\begin{array}{r}12.24 * * \\
(2.11)\end{array}$ & $\begin{array}{r}12.51 * * \\
(2.15)\end{array}$ & $\begin{array}{r}17.63 * * * \\
(4.14)\end{array}$ & $\begin{array}{r}17.67 * * * \\
(4.10)\end{array}$ & $\begin{array}{r}17.69 * * * \\
(4.11)\end{array}$ \\
\hline $\operatorname{Age}^{2}$ & $\begin{array}{r}-0.1631 * * \\
(-2.39)\end{array}$ & $\begin{array}{r}-0.1595 * * \\
(-2.35)\end{array}$ & $\begin{array}{r}-0.1622 * * \\
(-2.39)\end{array}$ & $\begin{array}{r}-0.2121 * * * \\
(-4.37)\end{array}$ & $\begin{array}{r}-0.2145 * * * \\
(-4.34)\end{array}$ & $\begin{array}{r}-0.2137 * * * \\
(-4.34)\end{array}$ \\
\hline Male & $\begin{array}{r}16.88 * * \\
(2.26)\end{array}$ & $\begin{array}{r}16.63 * * \\
(2.06)\end{array}$ & $\begin{array}{r}16.76^{* * *} \\
(2.08)\end{array}$ & $\begin{array}{r}36.91 * * * \\
(3.21)\end{array}$ & $\begin{array}{r}38.72 * * * \\
(3.38)\end{array}$ & $\begin{array}{r}38.25 * * * \\
(3.34)\end{array}$ \\
\hline Married Immigrants & $\begin{array}{l}-13.68 \\
(-0.66)\end{array}$ & $\begin{array}{l}-19.44 \\
(-0.93)\end{array}$ & $\begin{array}{l}-14.29 \\
(-0.69)\end{array}$ & $\begin{array}{l}-28.42 \\
(-1.56)\end{array}$ & $\begin{array}{r}-27.26 \\
(-1.51)\end{array}$ & $\begin{array}{l}-26.18 \\
(-1.46)\end{array}$ \\
\hline Family Class Category & $\begin{array}{l}-50.53 \\
(-1.40)\end{array}$ & $\begin{array}{l}-50.72 \\
(-1.20)\end{array}$ & $\begin{array}{l}-50.53 \\
(-1.29)\end{array}$ & $\begin{array}{l}-31.02 \\
(-1.56)\end{array}$ & $\begin{array}{r}-29.18 \\
(-1.57)\end{array}$ & $\begin{array}{r}-30.73 \\
(-1.46)\end{array}$ \\
\hline Business Class Category & $\begin{array}{r}-138.54 \\
(-1.51)\end{array}$ & $\begin{array}{r}-136.12 \\
(-1.25)\end{array}$ & $\begin{array}{r}-138.35 \\
(-1.51)\end{array}$ & $\begin{array}{r}-169.01 * * * \\
(-4.10)\end{array}$ & $\begin{array}{r}-170.55 * * * \\
(-4.03)\end{array}$ & $\begin{array}{r}-173.66 * * * \\
(-3.50)\end{array}$ \\
\hline Refugee Class Catgory & $\begin{array}{r}-87.97 * * * \\
(-2.97)\end{array}$ & $\begin{array}{r}-83.69 * * * \\
(-2.99)\end{array}$ & $\begin{array}{r}-87.41 * * * \\
(-2.96)\end{array}$ & $\begin{array}{r}-78.21 * * * \\
(-3.75)\end{array}$ & $\begin{array}{r}-82.83 * * * \\
(-3.91)\end{array}$ & $\begin{array}{r}-79.54 * * * \\
(-3.79)\end{array}$ \\
\hline Ontario Resident & $\begin{array}{r}-102.76 * * * \\
(-3.06)\end{array}$ & $\begin{array}{r}-103.97 * * * \\
(-3.08)\end{array}$ & $\begin{array}{r}-102.92 * * * \\
(-3.07)\end{array}$ & $\begin{array}{r}20.29 \\
(1.15)\end{array}$ & $\begin{array}{r}18.96 \\
(1.06)\end{array}$ & $\begin{array}{r}21.16 \\
(1.17)\end{array}$ \\
\hline Quebec Resident & $\begin{array}{r}-87.89 * * * \\
(-3.91)\end{array}$ & $\begin{array}{r}-92.07 * * * \\
(-3.96)\end{array}$ & $\begin{array}{r}-88.18 * * * \\
(-3.92)\end{array}$ & $\begin{array}{l}-24.88 \\
(-1.30)\end{array}$ & $\begin{array}{l}-26.21 \\
(-1.15)\end{array}$ & $\begin{array}{l}-28.07 \\
(-1.45)\end{array}$ \\
\hline British Columbia Resident & $\begin{array}{r}-178.62 * * * \\
(-3.42)\end{array}$ & $\begin{array}{r}-184.21 * * * \\
(-3.43)\end{array}$ & $\begin{array}{r}-179.14 * * * \\
(-3.43)\end{array}$ & $\begin{array}{r}94.59 \\
(1.28)\end{array}$ & $\begin{array}{r}95.61 \\
(1.52)\end{array}$ & $\begin{array}{r}105.12 \\
(1.44)\end{array}$ \\
\hline Invested Abroad & $\begin{array}{r}155.12 * * \\
(2.10)\end{array}$ & $\begin{array}{r}144.73 * * \\
(2.20)\end{array}$ & $\begin{array}{r}154.21 * * \\
(2.09)\end{array}$ & $\begin{array}{r}173.65 * * * \\
(4.02)\end{array}$ & $\begin{array}{r}183.42 * * * \\
(4.19)\end{array}$ & $\begin{array}{r}179.97 * * * \\
(4.15)\end{array}$ \\
\hline Community Member & $\begin{array}{r}84.13 * * * \\
(3.50)\end{array}$ & $\begin{array}{r}103.92 * * * \\
(4.20)\end{array}$ & $\begin{array}{r}98.91 * * * \\
(4.21)\end{array}$ & $\begin{array}{r}22.45 \\
(0.12)\end{array}$ & $\begin{array}{r}18.59 \\
(0.04)\end{array}$ & $\begin{array}{r}25.5 \\
(0.02)\end{array}$ \\
\hline Eastern Europe & $\begin{array}{r}27.27 * * * \\
(3.33)\end{array}$ & $\begin{array}{r}27.07 * * \\
(2.18)\end{array}$ & $\begin{array}{r}27.33 * * \\
(2.32)\end{array}$ & $\begin{array}{r}11.89 * * \\
(1.98)\end{array}$ & $\begin{array}{r}26.39 * * \\
(2.33)\end{array}$ & $\begin{array}{r}11.35^{*} \\
(1.95)\end{array}$ \\
\hline North Africa & $\begin{array}{r}114.89 * * * \\
(3.87)\end{array}$ & $\begin{array}{r}133.75 * * * \\
(3.87)\end{array}$ & $\begin{array}{r}114.21 * * * \\
(3.87)\end{array}$ & $\begin{array}{r}101.47 * * * \\
(4.54)\end{array}$ & $\begin{array}{r}127.67 * * * \\
(4.52)\end{array}$ & $\begin{array}{r}102.11 * * * \\
(4.53)\end{array}$ \\
\hline West Africa & $\begin{array}{r}90.29 * * * \\
(2.87)\end{array}$ & $\begin{array}{r}88.93 * * * \\
(2.91)\end{array}$ & $\begin{array}{r}89.29 * * * \\
(2.87)\end{array}$ & $\begin{array}{r}112.37 * * \\
(2.13)\end{array}$ & $\begin{array}{r}128.63 * * * \\
(2.88)\end{array}$ & $\begin{array}{r}133.06 * * \\
(2.09)\end{array}$ \\
\hline East Africa & $\begin{array}{r}120.07 * * \\
(2.63)\end{array}$ & $\begin{array}{r}115.91 * * \\
(2.07)\end{array}$ & $\begin{array}{r}117.84 * * \\
(2.20)\end{array}$ & $\begin{array}{r}102.01 * * \\
(2.70)\end{array}$ & $\begin{array}{r}105.49 * * \\
(2.59)\end{array}$ & $\begin{array}{r}101.18^{* *} \\
(2.64)\end{array}$ \\
\hline Central Africa & $\begin{array}{r}86.71 * * \\
(2.00)\end{array}$ & $\begin{array}{r}87.19 * * \\
(2.10)\end{array}$ & $\begin{array}{r}96.26 * * * \\
(2.98)\end{array}$ & $\begin{array}{r}74.21 * * \\
(2.60)\end{array}$ & $\begin{array}{r}73.53 * * * \\
(3.04)\end{array}$ & $\begin{array}{r}64.03 * * * \\
(3.50)\end{array}$ \\
\hline South Asia & $\begin{array}{r}141.85 * * * \\
(3.00)\end{array}$ & $\begin{array}{r}142.21 * * * \\
(2.99)\end{array}$ & $\begin{array}{r}135.3 * * * \\
(3.00)\end{array}$ & $\begin{array}{r}114.35 * * \\
(2.19)\end{array}$ & $\begin{array}{r}113.62 * * \\
(2.17)\end{array}$ & $\begin{array}{r}114.21^{* *} \\
(2.08)\end{array}$ \\
\hline Southeast Asia & $\begin{array}{r}168.04 * * * \\
(4.19)\end{array}$ & $\begin{array}{r}165.52 * * * \\
(4.18)\end{array}$ & $\begin{array}{r}155.97 * * * \\
(4.19)\end{array}$ & $\begin{array}{r}129.96 * * * \\
(7.83)\end{array}$ & $\begin{array}{r}114.37 * * * \\
(7.93)\end{array}$ & $\begin{array}{r}110.37 * * * \\
(7.56)\end{array}$ \\
\hline Caribbean & $\begin{array}{r}181.62 * * * \\
(3.74)\end{array}$ & $\begin{array}{r}187.51 * * * \\
(3.74)\end{array}$ & $\begin{array}{r}182.18 * * * \\
(3.74)\end{array}$ & $\begin{array}{r}171.04 * * * \\
(4.74)\end{array}$ & $\begin{array}{r}170.44 * * * \\
(4.67)\end{array}$ & $\begin{array}{r}170.15 * * * \\
(4.69)\end{array}$ \\
\hline South America & $\begin{array}{r}137.63 * * * \\
(2.57)\end{array}$ & $\begin{array}{r}143.75 * * * \\
(2.63)\end{array}$ & $\begin{array}{r}138.24 * * * \\
(2.58)\end{array}$ & $\begin{array}{r}112.99 * * \\
(2.31)\end{array}$ & $\begin{array}{r}118.86 * * \\
(2.29)\end{array}$ & $\begin{array}{r}128.67 * * \\
(2.22)\end{array}$ \\
\hline Central America & $\begin{array}{r}101.13 * * \\
(2.04)\end{array}$ & $\begin{array}{r}106.56 * * * \\
(3.53)\end{array}$ & $\begin{array}{r}101.72 * * \\
(2.14)\end{array}$ & $\begin{array}{r}55.79 * * * \\
(3.60)\end{array}$ & $\begin{array}{r}59.38 * * \\
(2.70)\end{array}$ & $\begin{array}{r}58.23 * * * \\
(3.13)\end{array}$ \\
\hline Number Killed by Disaster & $\begin{array}{r}0.0078 * * * \\
(3.64)\end{array}$ & & & $\begin{array}{r}0.0027 * * * \\
(3.39)\end{array}$ & & \\
\hline People Affected by Disaster & & $\begin{array}{r}0.000029 * * * \\
(3.63)\end{array}$ & & & $\begin{array}{r}0.000024 * * * \\
(3.44)\end{array}$ & \\
\hline Total Damages (in CAD\$) & & & $\begin{array}{r}0.000059 * * * \\
(3.64)\end{array}$ & & & $\begin{array}{r}0.000082 * * * \\
(4.12)\end{array}$ \\
\hline Constant & $\begin{array}{r}-552.43 * * * \\
(-3.04)\end{array}$ & $\begin{array}{r}-566.83 * * * \\
(-3.06)\end{array}$ & $\begin{array}{r}-554.31 * * * \\
(-3.05)\end{array}$ & $\begin{array}{r}-590.71 * * * \\
(-5.23)\end{array}$ & $\begin{array}{r}-593.89 * * * \\
(-5.18)\end{array}$ & $\begin{array}{r}-590.41 * * * \\
(-5.18)\end{array}$ \\
\hline Pseudo R2 & 0.033 & 0.0324 & 0.033 & 0.0324 & 0.0277 & 0.0295 \\
\hline Observations & 7460 & 7460 & 7460 & 7460 & 7460 & 7460 \\
\hline
\end{tabular}


A.5 Tobit Estimations for Monthly Remittance Levels for Single Adult Households Only (Tstatistics in brackets below the coefficient)

\begin{tabular}{|c|c|c|c|c|c|c|}
\hline \multirow[b]{2}{*}{ Variables } & \multicolumn{3}{|c|}{ Wave 2} & \multicolumn{3}{|c|}{ Wave 3} \\
\hline & \multicolumn{3}{|c|}{ Threshold: Total Damage $\geq \$ 1 \mathrm{M}$} & \multicolumn{3}{|c|}{ Threshold: Total Damage $\geq \$ 1 M$} \\
\hline $\begin{array}{l}\text { Total Household Income } \\
\text { (in \$1000s) }\end{array}$ & $\begin{array}{r}2.12 * * * \\
(3.48)\end{array}$ & $\begin{array}{r}2.18 * * * \\
(3.43)\end{array}$ & $\begin{array}{r}2.11 * * * \\
(3.42)\end{array}$ & $\begin{array}{r}2.12 * * * \\
(2.51)\end{array}$ & $\begin{array}{r}2.19 * * \\
(2.50)\end{array}$ & $\begin{array}{r}2.98 * * \\
(2.31)\end{array}$ \\
\hline (Total Household Income) $^{2}$ & & & & & & \\
\hline (in \$1000000s) & $\begin{array}{r}-0.0022 * * * \\
(-3.18)\end{array}$ & $\begin{array}{r}-0.0023 * * * \\
(-3.13)\end{array}$ & $\begin{array}{r}-0.0026 * * * \\
(-3.12)\end{array}$ & $\begin{array}{r}-0.0012 * * * \\
(-2.95)\end{array}$ & $\begin{array}{r}-0.0015 * * \\
(-2.13)\end{array}$ & $\begin{array}{r}-0.0015 * * \\
(-2.25)\end{array}$ \\
\hline Number of Jobs & $\begin{array}{r}16.38 * * \\
(2.75)\end{array}$ & $\begin{array}{r}23.72 * * \\
(2.68)\end{array}$ & $\begin{array}{r}33.58 * * \\
(2.54)\end{array}$ & $\begin{array}{r}34.77 * * \\
(2.64)\end{array}$ & $\begin{array}{r}30.11 * * \\
(2.34)\end{array}$ & $\begin{array}{r}32.15 * * \\
(2.50)\end{array}$ \\
\hline (Number of Jobs) $^{2}$ & $\begin{array}{r}-2.22 * * \\
(-2.69)\end{array}$ & $\begin{array}{r}-2.39 * * \\
(-2.50)\end{array}$ & $\begin{array}{r}-3.39 * * * \\
(-2.89)\end{array}$ & $\begin{array}{r}-2.62 * * \\
(-2.67)\end{array}$ & $\begin{array}{r}-1.96 * * \\
(-2.47)\end{array}$ & $\begin{array}{r}-2.21 * * * \\
(-3.10)\end{array}$ \\
\hline Yrs of Formal Education & $\begin{array}{l}-11.88 \\
(-0.78)\end{array}$ & $\begin{array}{l}-15.27 \\
(-0.99)\end{array}$ & $\begin{array}{r}-14.31 \\
(-0.99)\end{array}$ & $\begin{array}{l}-32.99 \\
(-1.24)\end{array}$ & $\begin{array}{l}-32.34 \\
(-1.30)\end{array}$ & $\begin{array}{l}-26.68 \\
(-1.35)\end{array}$ \\
\hline$(\text { Yrs of Formal Education })^{2}$ & $\begin{array}{r}0.5291 \\
(1.11)\end{array}$ & $\begin{array}{r}0.6125 \\
(1.26)\end{array}$ & $\begin{array}{r}0.5722 \\
(1.26)\end{array}$ & $\begin{array}{r}1.31 \\
(1.44)\end{array}$ & $\begin{array}{r}1.17 \\
(1.47)\end{array}$ & $\begin{array}{r}0.9296 \\
(1.39)\end{array}$ \\
\hline Age & $\begin{array}{r}52.37 * * * \\
(2.97)\end{array}$ & $\begin{array}{r}51.24 * * * \\
(2.94)\end{array}$ & $\begin{array}{r}46.31 * * * \\
(2.82)\end{array}$ & $\begin{array}{r}19.32 * * \\
(2.47)\end{array}$ & $\begin{array}{r}22.11 * * \\
(1.98)\end{array}$ & $\begin{array}{r}18.52 * \\
(1.96)\end{array}$ \\
\hline $\mathrm{Age}^{2}$ & $\begin{array}{r}-0.7501 * * \\
(-2.72)\end{array}$ & $\begin{array}{r}-0.7161 * * \\
(-2.66)\end{array}$ & $\begin{array}{r}-0.6438 * * \\
(-2.52)\end{array}$ & $\begin{array}{r}-0.2191 * \\
(-1.91)\end{array}$ & $\begin{array}{r}-0.2516 * * \\
(-1.99)\end{array}$ & $\begin{array}{r}-0.2018^{*} \\
(-1.96)\end{array}$ \\
\hline Male & $\begin{array}{r}32.37 * * \\
(2.75)\end{array}$ & $\begin{array}{r}36.65 * * * \\
(2.84)\end{array}$ & $\begin{array}{r}36.28 * * * \\
(2.82)\end{array}$ & $\begin{array}{r}34.98 * * \\
(2.57)\end{array}$ & $\begin{array}{r}38.34 * * \\
(2.32)\end{array}$ & $\begin{array}{r}35.84 * * \\
(2.05)\end{array}$ \\
\hline Married immigrants & $\begin{array}{r}-10.12 \\
(-0.21)\end{array}$ & $\begin{array}{r}-16.53 \\
(-0.98)\end{array}$ & $\begin{array}{r}-19.12 \\
(-0.96)\end{array}$ & $\begin{array}{r}-13.2 \\
(-0.50)\end{array}$ & $\begin{array}{r}-10.1 \\
(-0.98)\end{array}$ & $\begin{array}{r}-13.64 \\
(-0.10)\end{array}$ \\
\hline Business Class Category & $\begin{array}{r}-107.67 \\
(-1.36)\end{array}$ & $\begin{array}{r}-81.68 \\
(-1.20)\end{array}$ & $\begin{array}{r}-110.67 \\
(-1.19)\end{array}$ & $\begin{array}{r}-98.54 * * \\
(-2.10)\end{array}$ & $\begin{array}{r}-36.16 * * \\
(-2.25)\end{array}$ & $\begin{array}{r}-53.77 * * * \\
(-3.25)\end{array}$ \\
\hline Refugee Class Catgory & $\begin{array}{r}-91.29 * * \\
(-2.54)\end{array}$ & $\begin{array}{r}-113.35 * * * \\
(-2.85)\end{array}$ & $\begin{array}{r}-129.11 * * * \\
(-3.17)\end{array}$ & $\begin{array}{r}-107.22 * * * \\
(-4.03)\end{array}$ & $\begin{array}{r}-118.43 * * * \\
(-4.13)\end{array}$ & $\begin{array}{r}-113.73 * * * \\
(-4.15)\end{array}$ \\
\hline Ontario resident & $\begin{array}{r}-82.3 * * \\
(-2.44)\end{array}$ & $\begin{array}{r}-90.78 * * \\
(-2.57)\end{array}$ & $\begin{array}{r}-87.91 * * \\
(-2.57)\end{array}$ & $\begin{array}{r}31.32 \\
(0.88)\end{array}$ & $\begin{array}{r}40.53 \\
(1.10)\end{array}$ & $\begin{array}{r}40.32 \\
(1.15)\end{array}$ \\
\hline Quebec resident & $\begin{array}{r}-165.95 * * * \\
(-3.36)\end{array}$ & $\begin{array}{r}-173.76 * * * \\
(-3.39)\end{array}$ & $\begin{array}{r}-169.82 * * * \\
(-3.31)\end{array}$ & $\begin{array}{l}-45.89 \\
(-1.01)\end{array}$ & $\begin{array}{r}-27.38 \\
(-0.58)\end{array}$ & $\begin{array}{l}-17.54 \\
(-0.40)\end{array}$ \\
\hline British Columbia resident & $\begin{array}{r}-71.45 * * \\
(-2.43)\end{array}$ & $\begin{array}{r}-95.26 * * \\
(-2.74)\end{array}$ & $\begin{array}{r}-100.15 * * \\
(-2.50)\end{array}$ & $\begin{array}{r}32.69 \\
(0.79)\end{array}$ & $\begin{array}{r}27.39 \\
(0.41)\end{array}$ & $\begin{array}{r}28.72 \\
(0.22)\end{array}$ \\
\hline Invested abroad & $\begin{array}{r}176.19 * * \\
(2.39)\end{array}$ & $\begin{array}{r}180.12 * * \\
(2.37)\end{array}$ & $\begin{array}{r}157.94 * * \\
(2.24)\end{array}$ & $\begin{array}{r}88.84 * * \\
(2.09)\end{array}$ & $\begin{array}{r}116.43 * * \\
(2.07)\end{array}$ & $\begin{array}{r}101.21 * * \\
(2.21)\end{array}$ \\
\hline Community member & $\begin{array}{r}31.26 * * \\
(2.24)\end{array}$ & $\begin{array}{r}30.38 * \\
(1.95)\end{array}$ & $\begin{array}{r}31.93 * * \\
(2.00)\end{array}$ & $\begin{array}{r}13.48 * * \\
(2.12)\end{array}$ & $\begin{array}{r}12.47 * * \\
(2.08)\end{array}$ & $\begin{array}{r}19.43 * * \\
(2.35)\end{array}$ \\
\hline Eastern Europe & $\begin{array}{r}99.96 * \\
(1.95)\end{array}$ & $\begin{array}{r}105.17 * \\
(1.93)\end{array}$ & $\begin{array}{r}133.87 * * \\
(2.34)\end{array}$ & $\begin{array}{r}160.8 * * * \\
(3.29)\end{array}$ & $\begin{array}{r}117.74 * * * \\
(3.83)\end{array}$ & $\begin{array}{r}123.96 * * * \\
(3.79)\end{array}$ \\
\hline North Africa & $\begin{array}{r}24.48 * * \\
(2.10)\end{array}$ & $\begin{array}{r}24.74 * * \\
(2.12)\end{array}$ & $\begin{array}{r}37.43 * * \\
(2.79)\end{array}$ & $\begin{array}{r}16.37 * * \\
(2.36)\end{array}$ & $\begin{array}{r}54.04 * * \\
(2.17)\end{array}$ & $\begin{array}{r}32.96 * * \\
(2.07)\end{array}$ \\
\hline West Africa & $\begin{array}{r}103.51 * * * \\
(2.84)\end{array}$ & $\begin{array}{r}147.59 * * * \\
(3.36)\end{array}$ & $\begin{array}{r}146.32 * * * \\
(3.67)\end{array}$ & $\begin{array}{r}135.84 * * \\
(2.59)\end{array}$ & $\begin{array}{r}119.49 * * \\
(1.98)\end{array}$ & $\begin{array}{r}107.64 * * \\
(1.98)\end{array}$ \\
\hline East Africa & $\begin{array}{r}62.62 * * \\
(2.15)\end{array}$ & $\begin{array}{r}84.49 * * \\
(2.60)\end{array}$ & $\begin{array}{r}92.89 * * \\
(2.45)\end{array}$ & $\begin{array}{r}72.12 * * \\
(2.12)\end{array}$ & $\begin{array}{r}105.97^{* *} \\
(2.59)\end{array}$ & $\begin{array}{r}105.38 * * \\
(2.67)\end{array}$ \\
\hline Central Africa & $\begin{array}{r}102.66 * * \\
(2.10)\end{array}$ & $\begin{array}{r}87.94 * * \\
(2.12)\end{array}$ & $\begin{array}{r}74.23 * * \\
(2.02)\end{array}$ & $\begin{array}{r}114.22 * * \\
(2.76)\end{array}$ & $\begin{array}{r}119.11 * * * \\
(3.31)\end{array}$ & $\begin{array}{r}130.34 * * * \\
(3.36)\end{array}$ \\
\hline South Asia & $\begin{array}{r}112.78 * * \\
(2.53)\end{array}$ & $\begin{array}{r}200.02 * * * \\
(3.41)\end{array}$ & $\begin{array}{r}211.17 * * * \\
(3.65)\end{array}$ & $\begin{array}{r}149.54 * * \\
(2.11)\end{array}$ & $\begin{array}{r}121.54 * * \\
(2.47)\end{array}$ & $\begin{array}{r}150.32 * * \\
(2.12)\end{array}$ \\
\hline Southeast Asia & $\begin{array}{r}205.61 * * * \\
(5.25)\end{array}$ & $\begin{array}{r}248.51 * * * \\
(5.71)\end{array}$ & $\begin{array}{r}275.89 * * * \\
(6.02)\end{array}$ & $\begin{array}{r}267.31 * * * \\
(5.38)\end{array}$ & $\begin{array}{r}250.11 * * * \\
(5.75)\end{array}$ & $\begin{array}{r}285.32 * * * \\
(5.65)\end{array}$ \\
\hline Caribbean & $\begin{array}{r}168.42 * * * \\
(3.17)\end{array}$ & $\begin{array}{r}215.56 * * * \\
(3.69)\end{array}$ & $\begin{array}{r}242.73 * * * \\
(4.07)\end{array}$ & $\begin{array}{r}230.76 * * * \\
(3.80)\end{array}$ & $\begin{array}{r}284.26 * * * \\
(4.49)\end{array}$ & $\begin{array}{r}254.17 * * * \\
(4.26)\end{array}$ \\
\hline South America & $\begin{array}{r}112.05^{* *} * \\
(2.47)\end{array}$ & $\begin{array}{r}149.43 * * * \\
(2.88)\end{array}$ & $\begin{array}{r}171.39 * * \\
(2.11)\end{array}$ & $\begin{array}{r}140.25 * * \\
(2.16)\end{array}$ & $\begin{array}{r}142.71 * * \\
(2.60)\end{array}$ & $\begin{array}{r}136.78 * * \\
(2.43)\end{array}$ \\
\hline Central America & $\begin{array}{r}152.58 * * \\
(2.23)\end{array}$ & $\begin{array}{r}91.31 * * * \\
(2.85)\end{array}$ & $\begin{array}{r}121.97 * * \\
(2.15)\end{array}$ & $\begin{array}{r}80.52 * * \\
(2.55)\end{array}$ & $\begin{array}{r}69.61 * * * \\
(2.88)\end{array}$ & $\begin{array}{r}62.96 * * * \\
(2.90)\end{array}$ \\
\hline Number Killed by Disaster & $\begin{array}{r}0.0088 * * * \\
(4.52)\end{array}$ & & & $\begin{array}{r}0.0057 * * * \\
(4.39)\end{array}$ & & \\
\hline People Affected by Disaster & & $\begin{array}{r}.000023 * * * \\
(3.81)\end{array}$ & & & $\begin{array}{r}0.000021 * * * \\
(4.12)\end{array}$ & \\
\hline Total Damages (in CAD\$) & & & $\begin{array}{r}.000044 * * * \\
(5.30)\end{array}$ & & & $\begin{array}{r}0.000055^{* * * *} \\
(8.36)\end{array}$ \\
\hline Constant & $\begin{array}{r}-596.21 * * \\
(-2.53)\end{array}$ & $\begin{array}{r}-636.14 * * \\
(-2.47)\end{array}$ & $\begin{array}{r}-586.75 * * \\
(-2.37)\end{array}$ & $\begin{array}{r}-588.86 * * * \\
(-3.98)\end{array}$ & $\begin{array}{r}-646.44 * * * \\
(-3.91)\end{array}$ & $\begin{array}{r}-603.12 * * * \\
(-3.89)\end{array}$ \\
\hline Pseudo R2 & 0.0618 & 0.0551 & 0.061 & 0.0621 & 0.0657 & 0.0787 \\
\hline Observations & 2078 & 2078 & 2078 & 2078 & 2078 & 2078 \\
\hline
\end{tabular}


A.6 Tobit Estimations for Monthly Remittance Levels for Principal + Spouse Respondents (T-statistics in brackets below the coefficient)

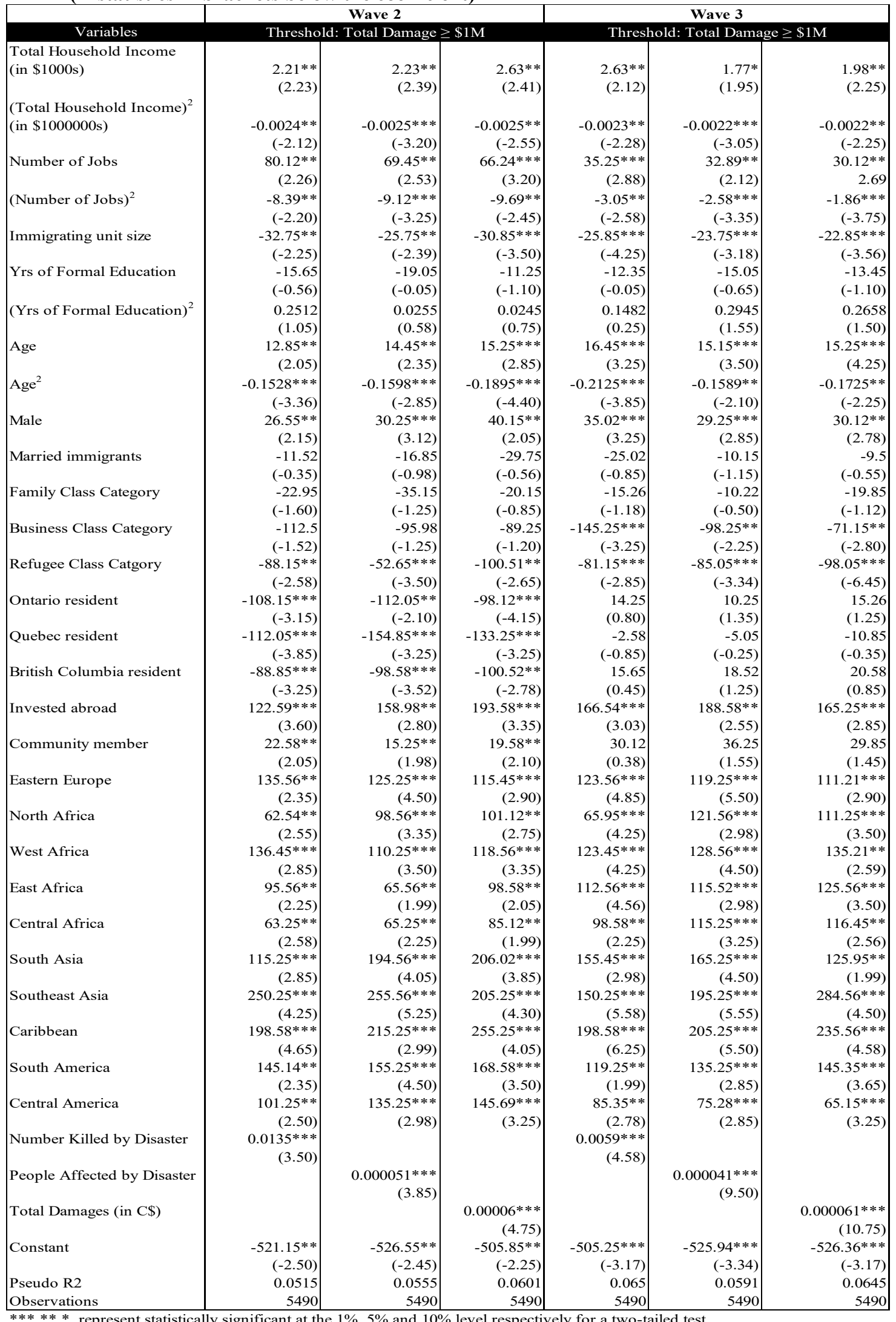




\section{A.7 Countries included under Each Region}

\begin{tabular}{|l|l|}
\hline \multicolumn{1}{|c|}{ World region } & \multicolumn{1}{|c|}{ Countries } \\
\hline Eastern Europe & $\begin{array}{l}\text { Albania, Bulgaria, Czech and Slovak Federal Republic, Hungary, Poland, Romania, } \\
\text { U.S.S.R., Yugoslavia }\end{array}$ \\
\hline North Africa & Algeria, Egypt, Libya, Morocco, Sudan, Tunisia, Western Sahara \\
\hline West Africa & $\begin{array}{l}\text { Benin, Burkina Faso, Ivory Coast, Cape Verde, Gambia, Ghana, Guinea, Guinea- } \\
\text { Bissau, Liberia, Mali, Mauritania, Niger, Nigeria, Senegal, Sierra Leone and Togo }\end{array}$ \\
\hline East Africa & $\begin{array}{l}\text { Burundi, Eritrea, Ethiopia, Kenya, Madagascar, Republic of Djibouti, Rwanda, } \\
\text { Somalia, Sudan, Tanzania, Uganda }\end{array}$ \\
\hline Central Africa & $\begin{array}{l}\text { Angola, Cameroon, Central African Republic, Chad, Democratic Republic of the } \\
\text { Congo, Republic of Congo, Equatorial Guinea, Gabon }\end{array}$ \\
\hline South Asia & $\begin{array}{l}\text { Afghanistan, Bangladesh, Bhutan, India, Nepal, Maldives, Pakistan, } \\
\text { Sri Lanka. }\end{array}$ \\
\hline $\begin{array}{l}\text { Caribbean/Central } \\
\text { and South America }\end{array}$ & $\begin{array}{l}\text { Brunei, Cambodia, East Timor, Indonesia, Laos, Malaysia, Philippines, Singapore, } \\
\text { Thailand, Union of Myanmar, Viet Nam }\end{array}$ \\
$\begin{array}{l}\text { Anguilla, Antigua, Argentina, Aruba, Bahamas, Barbados, Belize, Bermuda, Bolivia, } \\
\text { Brazil, Cayman Islands, Chile, Colombia, Costa Rica, Cuba, Dominica, Dominican } \\
\text { Republic, Ecuador, El Salvador, Falkland Islands, French Guiana, Grenada, } \\
\text { Guadeloupe, Guatemala, Guyana, Haiti, Honduras, Jamaica, Martinique, Mexico, } \\
\text { Montserrat, Netherlands Antilles, Nicaragua, Panama, Paraguay, Peru, Puerto Rico, } \\
\text { St. Christopher and Nevis, St. Lucia, St. Vincent and the Grenadines, Suriname, } \\
\text { Trinidad and Tobago, Turks and Caicos Islands, Uruguay, Venezuela, Virgin Islands } \\
\text { (British), Virgin Islands (U.S.) }\end{array}$ \\
\hline
\end{tabular}

Source: Statistics Canada, 2016 


\section{References}

Agarwal, R. \& Horowitz, A. W. (2002). Are international remittances altruism or insurance? Evidence from Guyana using multiple-migrant households. World Development, 30(11), 2033-2044. https://doi.org/10.1016/S0305-750X(02)001183

Anghel, R. G., \& Horvath, I. (2009). Sociologia Migraţiei. Teori Teorii şi studii de caz româneşti. Retrieved from http://www.academia.edu/1029015/Sociologia_Migra\%C5\%A3iei._Teorii_\%C5 \%9Fi_Studii_de_Caz_Rom\%C3\%A2ne\%C5\%9Fti

Brown, R. P.C., \& Piorine, B. (2005). A model of migrants' remittances with human capital investment and intrafamilial transfers. International Migration Review, 39(2), 407-438. doi: 10.1111/j.1747-7379.2005.tb00272.x

Carling, J. (2008). The determinants of Migrant Remittances. Oxford Review of Economic Policy, 3(1), 582-599. doi: https://doi.org/10.1093/oxrep/grn022

Cerón Monroy, H. (2004). "El rol del empleo no agropecuario como estrategia de ingreso en la reduccion de la pobreza en El Sector Rural De México.” Paper presented at the seminar-workshop, Migracion, proreza y estructura de la economia rural Mexicana, PRESCESAM and REAP, 20-21 September, El Colegio de Mexico.

Chowdhury, M., \& Das, A. (2016). Remittance Behaviour of Chinese and Indian Immigrants in Canada. Review of Economics, 67(2), 185-208. doi: 10.1515/roe2015-1004

Citizenship and Immigration Canada [CIC]. (2007). Facts and Figures: Immigration Overview: Permanent and Temporary Workers. Retrieved from http://www.cic.gc.ca/english/pdf/pub/facts2007.pdf. 
Clarke, G. \& Wallsten, S. (2004). Do Remittances Protect Households in Developing Countries Against Shocks? Evidence from a Natural Disaster in Jamaica. Washington, DC: Mimeo

Collier, W., Piracha, M., \& Randazzo, T. (2011). Remittances and Return Migration. Institute for the Study of Labor Discussion Paper(6091). Retrieved from http://ftp.iza.org/dp6091.pdf.

Cox, D. (1987). Motives for private income transfers. Journal of Political Economy, 95(3), 508-546. https://doi.org/10.1086/261470

Cox, D., Eser, Z., \& Jimenez, E. (1998). Motives for private transfers over the life cycle: An analytical framework and evidence from Peru. Journal of Development Economics, 55(1), 57-81. https://doi.org/10.1016/S0304-3878(97)00056-4

Debnath, P. (2015). Climate Change-Induced Migration and Post-Disaster Remittance Responses through a Gender Lens. In F. Hillmann, M. Pahl, B. Rafflenbeul, \& H.Sterly (Eds.), Environmental Change, Adaptation and Migration: Bringing in the Region (pp.186-199). United Kingdon: Palgrave Macmillian

Durand, J., Parrado, E. A. \& Massey, D., S. (1996). Migradollars and Development: A Reconsideration of the Mexican Case. International Migration Review, 30(2), 423-444. doi: 10.2307/2547388

Durdu, C. B., \& Sayan, S. (2010). Emerging market business cycles with remittance fluctuations. IMF Staff Papers, 57(2), 303-325. doi/10.1111/j.14682435.2009.00591.

EM-DAT: The OFDA/CRED International Disaster Database, Université Catholique de Louvain, Brussels, Belgium. (Available at: www.em-dat.net)

EM-DAT: Glossary of Terms. Retrieved from https://www.emdat.be/Glossary 
Funkhouser, E. (1995). Remittances from international migration: A comparison of El Salvador and Nicaragua. The Review of Economics and Statistics, 77(1), 137-146. doi: $10.2307 / 2109999$

Gammage, S. (2004). Exercising Exit, Voice and Loyalty: A Gender Perspective on Transnationalism in Haiti. Development and Change, 35(4), 743-71. doi: 10.1111/j.0012-155X.2004.00378.x

Ghosh, B. (2006). Migrants' Remittances and Development: Myths, Rhetoric and Realities. Retrieved from http://publications.iom.int/system/files/pdf/migrants_remittances.pdf

Glick Schiller, N., Basch, L., \& Blanc-Szanton, C. (1992). Transnationalism: A New Analytic Framework for Understanding Migration. In S. Vertovec \& R. Cohen (Eds.), Migration, Diasporas and Transnationalism (pp. 26-50). Cheltenham: Edward Elgar

Glytsos, N. P. (1988). Remittances in Temporary Migration: A Theoretical Model and its Testing with the Greek-German Experience. Review of World Economics, 124(3), 524-49. doi:10.1007/BF02708664

Glytsos, N. P. (2002). The Role of Migrant Remittances in Development: Evidence from Mediterranean Countries. International Migration, 40(1), 5-26. doi: $10.1111 / 1468-2435.00183$

Gubert, F. (2002). Do migrants insure those who stay behind? Evidence from the Kayes Area (Western Mali). Oxford Development Studies, 30(2), 267-287. http://dx.doi.org/10.1080/1360081022000012699 
Houle, R. \& Schellenberg, G. (2008a). Remittances by Recent Immigrants, Statistics Canada. Retrieved from http://www.statcan.gc.ca/pub/75-001x/2008107/pdf/10656-eng.pdf

Houle, R. \& Schellenberg, G. (2008b). Remittance Behaviours Among Recent Immigrants in Canada. Retrieved from http://www.statcan.gc.ca/pub/11f0019m/11f0019m2008312-eng.pdf

Hugo, G. (1996). Environmental Concerns and International Migration. The international Migration Review, 30(1), 105-131. doi: 10.2307/2547462

International Organization for Migration [IOM]. (2015). World Migration Report 2015. Retrieved from http://publications.iom.int/system/files/wmr2015_en.pdf

Johnson, G. \& Whitelaw, W.E. (1974). Urban-Rural Income Transfers in Kenya: An Estimated-Remittances Function. Economic Development and Cultural Change, 22(3), 473-479. Retrieved from http://www.jstor.org/stable/1152632

Katz, E. \& Stark, O. (1986). Labor Migration and Risk Aversion in Less Developed Countries. Journal of Labor Economics, 4(1), 134-149. Retrieved from http://www.jstor.org/stable/2534880

Kelly, P. (2003). Canadian-Asian Transnationalism. Canadian Geographer 47(3), 209218. doi: 10.1111/1541-0064.t01-1-00018

Loxley, J., Sackey, H. A., \& Khan, S. (2015). African immigrants in Canada: a profile of human capital, income and remittance behaviour. Canadian Journal of Development Studies/Revue canadienne d'études du développement, 36(1), 3-23. doi: $10.1080 / 02255189.2016 .1199531$ 
Lucas, R., \& Stark, O. (1985). Motivations to remit: evidence from Botswana. Journal of Political Economy, 93(5), 901-918. Retrieved from http://www.jstor.org/stable/1833062

Mamattah, S. (2006). Migration and transnationalism: the complete picture? A case study of Russians living in Scotland. eSharp, 6(2), 1-22. Retrieved from http://www.gla.ac.uk/media/media_41186_en.pdf

Massey, D., Arango, J., Hugo, G., Kouaouci, A., Pellegrino, A. \& Taylow, J.E. (1993). Theories of International Migration: A Review and Appraisal. Population and Development Review, 19(3), 431-466. doi: 10.2307/2938462

Massey, D., \& Basem, L. (1992). Determinants of savings, remittances and spending patterns among U.S. migrants in four Mexican communities. Sociological Inquiry, 62(2), 185-207. doi: 10.1111/j.1475-682X.1992.tb00193.x

Massey, D., \& Parrado, E. (1994). Migradollars: the remittances and savings of Mexican migrants to the USA. Population Research and Policy Review, 13(1), 3-30. Retrieved from http://www.jstor.org/stable/40229687

Menjivar, C., DaVanza, J., Greenwell L., \& Valdez, R. (1998). Remittance behavior among Salvadoran and Filipino immigrants in Los Angeles. International Migration Review, 32(1), 97-126. doi: 10.2307/2547562

Merkle, L., \& Zimmermann, K. (1992). Savings, remittances and return migration. Economic Letters, 38(1), 77-81. Retrieved from https://doi.org/10.1016/01651765(92)90165-U

Mohapatra, S., Joseph, G., \& Ratha, D. (2012). Remittances and Natural Disasters: Expost Response and Contribution to Ex-ante Preparedness. Environment, 
Development and Sustainability, 14(3), 365-387. doi: 10.1007/s10668-011-93308

Noy, I. (2008). The Macroeconomic Consequences of Disasters. Journal of Development Economics 88(2), 221-231. Retrieved from ttp://www.sciencedirect.com/science/article/pii/S0304-3878(08)00031-X

Portes, A., Guarzino L. E., \& Landolt, P. (1999). The Study of Transnationalism: Pitfalls and Promise of an Emergent Research Field. Ethnic and Racial Studies, 22(2), 217-237. doi:10.1080/014198799329468

Porumbescu, A. (2015). Defining the New Economics of Labour Migration Theory Boundaries: A Sociological-Level Analysis of International Migration. Retrieved from http://cis01.central.ucv.ro/revistadestiintepolitice/files/numarul45_2015/6.\%20De fining\%20the \%20New\%20Economics\%20of\%20Labor\%20Migration\%20Theory \%20Boundaries...\%20pp.\%2055-64.pdf

Rodriguez, E. (1996). International migrants' remittances in the Philippines. The Canadian Journal of Economics, 29(4). S427-S432. doi: 10.2307/136081

Sayan, S., \& Tekin-Koru, A. (2012). Remittances, business cycles and poverty: The recent Turkish experience. International Migration, 50(s1). Doi: 10.1111/j.14682435.2009.00591

Secondi, G. (1997). Private Monetary Transfers in Rural China: Are Families Altruistic? Journal of Development Studies 33(4), 487-511. doi: $10.1080 / 00220389708422478$

Schellenberg, G., \& Maheux, H. (2007). Immigrants' perspectives on their first four years in Canada: Highlights from three waves of the Longitudinal Survey of 
Immigrants to Canada. Retrieved from http://www.statcan.gc.ca/pub/11-008x/2007000/pdf/9627-eng.pdf

Shooshtari, S., Harvey, C. D., Ferguson, E., Heinonen, T., \& Khan, S. (2014). Effects of remittance behavior on the lives of recent immigrants to Canada from the Philippines: A population-based longitudinal study. Journal of Family and Economic Issues, 35(1), 95-105. doi: https://doi.org/10.1007/s10834-013-9356-1

Simmons, A., Plaza, D., \& Piché, V. (2005). The Remittance Sending Practices of Haitians and Jamaicans in Canada. Retrieved from http://www.un.org/esa/population/meetings/IttMigLAC/P01_ASimmons.pdf

Stanwix, C., \& Connell, J. (1995). To the islands: The remittances of Fijians in Sydney. Asian and Pacific Migration Journal 4(1), 69-88. doi: $10.1177 / 011719689500400104$

Stark, O. \& Bloom, D. (1985). The New Economics of Labor Migration. The American Economic Review, 75(2), 173-178. Retrieved from http://www.jstor.org/stable/1805591

Stark, O., \& Lucas, R. (1988). Migration, Remittances and Family. Economic Development and Cultural Change 36(3), 465-81. Retrieved http://www.jstor.org/stable/1153807

Statistics Canada. (n.d.). Microdata User Guide: Longitudinal Survey of Immigrants to Canada Wave 3. Retrieved from http://www23.statcan.gc.ca/imdbbmdi/document/4422_D1_T1_V3-eng.pdf.

Statistics Canada. (2006). Labour Force Indicators for Persons Aged 25 to 44 by Immigrant Status, Selected Metropolitan Areas, 1991, 1996, and 2001. Retrieved from 
http://www.12.statcan.ca/english/census01/products/analytic/companion/paid/tabl es/labindcma.cfm

Statistics Canada. (2016). Countries by World Region. Retrieved from http://www.statcan.gc.ca/pub/82-622-x/2011008/tb1/tbla-eng.htm

Suleri, A., \& Savage, K. (2006). Remittances in Crisis: A Case Study of Pakistan. Retrieved from https://www.odi.org/sites/odi.org.uk/files/odi-assets/publicationsopinion-files/385.pdf

Unheim, P., \& Rowlands, D. (2012). Micro-level Determinants of Remittances from Recent Migrants to Canada. International Migration, 50(4), 124-139. doi: $10.1111 / j .1468-2435.2011 .00718 . x$

Vanwey, L. (2004). Altruistic and contractual remittances between male and female migrants and households in rural Thailand. Demography, 41(4), 739-756. Retrieved from http://www.jstor.org/stable/1515228

Vertovec, S. (2001). Transnationalism and Identity. Journal of Ethnic and Migration Studies, 27(4), 573-582. doi:10.1080/13691830120090386

Vete, M. (1995). The determinants of remittances among Tongans in Auckland. Asian and Pacific Migration Journal, 4(1), 55-68. doi: 10.1177/011719689500400103

The World Bank. (2006). Global Economic Prospects 2006: Economic Implications of Remittances and Migration. Retrieved from http://pubdocs.worldbank.org/en/346121443469727614/Global-EconomicProspects-2006-Economic-implications-of-remittances-and-migration.pdf The World Bank. (2016). Migration and Remittances Factbook 2016, Third Edition. Retrieved from 
https://openknowledge.worldbank.org/bitstream/handle/10986/23743/9781464803 192.pdf

The World Bank Open Data.(2016). Retrieved from http://data.worldbank.org/ Wu, T. (2006). The Role of Remittances in Crisis. An Aceh Research Study. Retrieved from https://www.odi.org/sites/odi.org.uk/files/odi-assets/publications-opinionfiles/408.pdf

Yang, D. (2007). Coping with Disaster: The Impact of Hurricanes on International Financial Flows, 1970-2002. National Bureau of Economic Research. doi: $10.3386 /$ w 12794 


\section{Chapter 3: Climate Change Induced Migration and Post Disaster Remittance Responses through a Gender Lens}

\subsection{Introduction}

Bangladesh, one of the most environmentally vulnerable countries of the world, has become the locus of severe and devastating weather events. Between 1877 and 1995, the country was hit by 154 cyclones, including 43 severe cyclonic storms, 43 cyclonic storms, and 68 tropical depressions (Dasgupta et al., 2011). Furthermore, with almost 3 million people displaced by natural disasters during the period 2008-2012, the Internal Displacement Monitoring Centre ranks Bangladesh among the top 10 countries producing disaster-induced displacement (International Displacement Monitoring Centre [IDMC], 2013).

Although a few recent studies on Bangladesh have focused on examining the effect of climate change on people's decision to migrate (IOM, 2009), there is a significant gap in the literature when it comes to exploring the responsiveness of remittances sent by Bangladeshi migrants in the aftermath of natural disasters. Given that Bangladesh has the largest diaspora savings (US $\$ 9.5$ billion) among the low-income countries and remittances account for 9-10 per cent of the country's Gross Domestic Product (2014), it is important to examine the relationship between natural disasters and the level of remittances received (The World Bank, 2015). This gap is further pronounced when trying to understand how existing gender relations within society shape the way female and male migrants remit and how each of these groups respond in the aftermath of a disaster affecting their households in the country of origin.

This chapter addresses some of these gaps by examining the remitting behaviour of men and women whose home communities face different risks of extreme weather. Using 
primary data collected through 118 in-depth field interviews with migrant workers from two villages located near the southwest border of Bangladesh, this chapter investigates the responsiveness of remittances sent by these migrants in the aftermath of natural disasters affecting their home communities. In doing so, this chapter will also shed light on how the culturally-determined roles of women in these traditional and patriarchal communities shape their remitting behaviour in post disaster situations. Furthermore, this chapter will also examine if some of the existing claims of the remittance literature hold true for this unique dataset, such as the effect of a migrant's age, marital status and migration duration on the decision to remit.

This remainder of this chapter is structured as follows. Section 3.2 provides a brief review of the existing literature on migration and remittances. Section 3.3 describes the data collection methodology and provides background information about the study sites and the profile of the migrants interviewed. Section 3.4 discusses the results in detail and Section 3.5 presents sensitivity analysis of the results discussed. Section 3.6 concludes the chapter.

\subsection{Literature Review}

The motives for and purposes of remittances have been a constant source of debate and interpretation among researchers. The New Economics of Labour Migration (NELM) theory and its extensions suggest that one commonly-adopted environment risk-mitigation strategy by households is to engage in labour migration as a means to diversify household income sources (Katz \& Stark, 1986; Stark \& Bloom, 1985). Migration is viewed as an investment and remittances are labelled as a return on that investment. According to this theory, migration decisions are made by families (households) and not by individual migrants as claimed by the traditional neoclassical theorists (Massey et al., 1993). Migrants 
send remittances to secure and smooth their families' food consumption in a context of missing or imperfect financial and insurance markets (Gubert, 2002).

Rooted in this theoretical framework is this chapter's claim that when households in countries of origin are affected by natural disasters, migrants will respond by remitting more to help their households in distress. A review of the current literature suggests that remittance inflows increase or remain relatively stable after the onset of large shocks, such as, natural disasters, macroeconomic or financial crises and armed conflicts (Clarke \& Wallsten, 2004; Mohapatra, Joseph, \& Ratha, 2012; Weiss Fagen \& Bump, 2006; The World Bank, 2006). A 2012 study analyzing cross-country macroeconomic data indicates that remittances increase in the aftermath of natural disasters in countries that have a larger number of migrants living abroad (Mohapatra et al., 2012). Another aggregate study examining the impact of hurricanes concludes that hurricane damages lead to increases in remittance inflows to poorer countries (Yang, 2007). A country case study on Zimbabwe found that during its 1991-92 drought, remittances received by rural families mollified the effect of drought within those communities (Benson \& Clay, 2004; Hicks, 1993). In Haiti, in-kind transfers from friends and families abroad helped households deal with income shocks from Cyclone Jeanne (Weiss Fagen, 2006). Similarly, a case study that explored the effects of the 2005 earthquake in Pakistan indicated that remittances were indeed a significant factor in the recovery and reconstruction of the four villages being studied (Suleri \& Savage, 2006). An Indonesian case study found that remittance-receiving households recovered faster in the aftermath of the 2004 Tsunami (Wu, 2006).

The significance of remittances as an informal arrangement for income redistribution has given rise to a growing literature on motives for giving (Cox, 1987; Cox, Eser, \& Jimenez, 1998; Lucas \& Stark, 1985; Secondi, 1997). Becker (1974) characterizes 
such transfers as motivated by altruism. This altruistic behaviour of migrants "is modelled through allowing the migrants to derive utility from the consumption level of those leftbehind" (Gubert, 2002, p. 268). This model implies that there is an inverse relationship between the income of the left-behind households and the level of remittances they receive. Migrants will adjust the amount of remittances they send based on the income of their leftbehind households.

Other factors determining a migrant's decision to remit include the migrant's individual characteristics, such as age, sex, marital status, duration of migration. Ghosh (2006) suggests that there is a linear relationship between a migrant's age and the amount he or she remits. His research indicates that younger migrants (under 40) remit more. In contrast, other studies indicate a non-linear relationship - remittances rise with age but at a decreasing rate (Merkle \& Zimmermann, 1992; Unheim \& Rowlands, 2012).

There is no strong consensus among the scholars regarding the role of a migrant's sex on remitting behaviour. Some studies indicate that females remit less than their male counterparts (Massey \& Parado, 1994; Merkle \& Zimmermann, 1992; Sørensen, 2005), while others conclude the opposite (Lucas \& Stark, 1985). For example, a study on remitting behaviour in South Africa concluded that "employed male migrants are 25 per cent less likely than employed female migrants to remit" (Collinson, Tollman, Kahn, \& Clark, 2003, p. 12), whereas a study by Collier, Priacha and Randazzo (2011) on return migrants to Algeria, Tunisia and Morocco found that a migrant's sex had no impact on his or her decision to remit. Furthermore, some researchers found that although females may remit smaller amounts, these amounts constitute a higher proportion of their overall earnings compared to those sent by male migrants (Chant \& Radcliffe, 1992; Curran \& Saguy, 2001; Rodriguez, 1996; Tacoli, 1999). Consequently, Piper (2005) and Ghosh 
(2006) concluded that the literature is inconclusive on this issue, and any trends are likely to be context specific.

The influence of the migrant's marital status on the amount remitted is also a crucial factor that will be investigated in this chapter. However, a study by Collier et al. (2011) found that marital status did not influence a migrant's decision to remit. Nonetheless, others state that married migrants who migrate with their families remitted less to their home countries (Unheim \& Rowlands, 2012) compared to migrants who left their spouses and children behind (Debnath \& Selim, 2009). Gedeshi (2002) also suggests that for many married migrants, the primary recipients of their remittances are their spouses and children who remained in their home communities.

The duration of migration (temporary versus permanent) is another powerful determinant of remittances. According to Ramamurthy (2003), temporary migration results in higher flows of remittances than permanent migration. A recent analysis by Dustmann and Mestres (2010) of immigrants to Germany also shows that temporary migrants remit far more than permanent migrants. Consequently, if this relationship holds true for the 118 migrants interviewed in this study, this chapter expects to observe similar results.

The above determinants that are most often explored by migration scholars inform the choice of control variables used in the equation estimated in this chapter. The NELM theory states that migration is a decision that is made by households to diversify their income sources, however, the theory does not identify specific variables that would capture this. What NELM provides is an overarching framework that views remittance earning as a separate source of income that household rely on to reduce adverse impacts from challenging times/unfavourable events. The analysis in this chapter looks for evidence to see if the overarching NELM theoretical framework holds true for the case examined here. 


\subsection{Data: Methodology, Description of the Study Site and the Characteristics of the Migrants Interviewed}

\subsubsection{Survey sites}

\subsubsection{Rationale Behind Choosing the Survey Sites}

The findings of this chapter are based on data collected through 118 in-depth interviews with migrants ${ }^{17}$ from two villages in the southwest part of Bangladesh near the Bangladesh-India border. The reasons for choosing this migration corridor as well as these two villages are twofold. First, the Bangladesh-India migration corridor is the third largest migration corridor in the world preceded by the Mexico and US corridor and the Russia and Ukraine corridor (The World Bank, 2015). Second, these two bordering villages have similar socio-economic conditions and are distinguished mainly by their level of susceptibility to natural disasters. Both villages have a population of less than 20,000 (Bangladesh Bureau of Statistics, 2010) and a migrant population of more than 10 per cent. ${ }^{18}$ The economic conditions as well as the traditional and cultural norms are similar between the two villages. ${ }^{19}$ Thus, choosing these two villages allows this chapter to explore the effect of the incidence of natural disasters on both the decision to migrate as well as remitting behaviour.

\subsubsection{Who were Surveyed?}

The field interviews were conducted by the author between April and May 2015. Every attempt was made to ensure that participation in the survey was as open as possible to all migrants in the two villages. The survey sample includes migrant households that

\footnotetext{
${ }^{17}$ During the time of the field research, these migrants were home on vacation visiting their households in Bangladesh.

${ }^{18}$ Internal information collected by the local migrant organization.

${ }^{19}$ Internal information collected by the local migrant organization.
} 
have either participated or continue to participate in activities organized by the local migrant organization. ${ }^{20}$ An overwhelming majority of the migrant households in these villages participated in one form or the other in activities organized by the local migrant organization. The migrant organization indicated that it has a community outreach rate of over 95 per cent in both villages.

Posters inviting migrants to voluntarily participate in this survey were placed outside the regular meeting places (offices) of the migrant organization in these two villages. The meeting places are all located in relatively central areas of the village that are easily accessible by migrants and their families as they frequent these locations to receive numerous services from the organization including pre-departure orientation trainings for migrants and their families, and vocational trainings. Consequently, the assumption that most eligible participants in the two communities would have been aware of the interviews can be made with reasonable confidence. Furthermore, to ensure that all migrants (men and women) within these villages felt equally welcome and comfortable to participate in this survey, the posters indicated that the interviews could take place at a location where the migrant felt most comfortable. This included giving the migrant a choice of being interviewed in their homes as well as in private meeting rooms in the offices of the migrant organization. While the requirement of voluntary participation and the limited time and resources available for the study obviously compromises any claim of complete randomness, all reasonable efforts were made to ensure that the sample was as unbiased as possible. Furthermore, in his comments about the study sample, the Executive Director of

\footnotetext{
${ }^{20}$ At the time of the field interviews, there was only one migrant organization working in both the villages. This organization has been working in the area since 1991. The author benefited from the local knowledge of the migrant organization. In order to protect the confidentiality of the interviewees, the name of the organization is not referenced in this chapter.
} 
the local migrant organization stated, "the study participants seemed representative of the overall migrant population in these two villages."

To further understand how representative the survey sample is of the overall population (non-migrant and migrant households) in these two villages, it is important to note that the average monthly income of agricultural households in these two villages is approximately Taka $6,500^{21}$ (US\$84) and the average total monthly income (including remittances) of the migrant households in these two villages is approximately Taka 7,000 (US\$90). All the migrants in the study sample are from the same religious background (Muslims) as is more than 95 per cent of the village population in both villages. The social, cultural and religious norms of the study sample are reflective of the overall migrant population as well as the general population in these two villages. ${ }^{22}$ Therefore, it could be reasonably stated that from a socio-economic perspective, the study sample of 118 is broadly representative of the overall migrant population as well as the general community in these two villages.

Furthermore, the social, cultural and religious norms of these two-rural agriculturalbased villages are similar to those in other rural villages in Bangladesh dominated by agricultural activity. ${ }^{23}$ Agriculture is the main livelihood option for more than 75 per cent of the population in both villages (Bangladesh Bureau of Statistics, 2010). Ninety-five per cent of the migrant households interviewed are agrarian households and remittances make

\footnotetext{
${ }^{21}$ Migrant's household income information was collected by the local migrant organization through their internal survey work and further verified by information collected from a smaller subset of migrants from both villages. Agricultural income includes income from crops and livestock production.

${ }^{22}$ Internal information collected by the local migrant organization.

${ }^{23}$ Internal information collected by the local migrant organization.
} 
up more than 80 per cent of their total household income. ${ }^{24}$ From a household income perspective these two villages are also similar to other rural villages in Bangladesh. At the national level, the average monthly income for households engaged in agriculture is approximately Taka 7,255 (US\$93) (Bangladesh Bureau of Statistics, 2017), which is similar to that of these two villages (Taka 6,500 or US\$84).

The sampling method and procedures were designed to make the sample as random as possible. Since the characteristics of the sample are close to those of the population of the villages and their migrant households, the method seems to have yielded a reasonably representative sample, which is consistent with randomness.

To protect the confidentiality of the interviewees, the names of the two villages have been changed to Village A and Village B. Village B is frequently affected by mild and severe natural disasters including cyclones, hailstorms, flooding, and extreme heat. In contrast, Village A suffers from far fewer weather-related disasters. It is important to note that Bangladesh is a global hotspot for natural disasters, and as a result almost all parts of the country are affected by natural disasters to a certain extent. Therefore, Village A is not a disaster-free zone; rather, it is one that experiences less severe weather-related events in comparison to Village B.

Traditionally, migrants from these villages have been men (Debnath \& Selim, 2009). However, much like the rest of the country, the last two decades have seen an increase in the number of female migrants from these villages.

\footnotetext{
24 The difference in the percentages (75\% vs. 95\%) can be explained by anecdotal evidence collected during the in-depth interviews. On average, it appears that agrarian families in these two villages participate more in the migration process compared to non-agrarian families.
} 


\subsubsection{Profile of the Study Population and their Migration Experiences}

The study population only includes semi-skilled and unskilled migrant workers. This is reflective of the overall migrant population in these two villages. ${ }^{25}$ All the migrants are from the same religious background (Muslims). The share of male and female migrants from each village is detailed in Table 3.1.

Table 3.1: Share of Female and Male Migrants in Villages A and B

\begin{tabular}{|l|c|c|}
\hline & Number of Male Migrants & Number of Female Migrants \\
\hline Village A & 33 & 13 \\
\hline Village B & 55 & 17 \\
\hline Total & $\mathbf{8 8}$ & $\mathbf{3 0}$ \\
\hline
\end{tabular}

More than 95 per cent of these migrant workers are high-school drop-outs with an average of approximately six years of formal schooling. Among the interviewees, five per cent of male migrants never attended any formal or informal education institutions, compared to three per cent of female migrants. All the migrants interviewed in this study engaged in international migration and went to the neighbouring country (India) due to the proximity of these villages to the Indian border. The migrants entered through their nearest border entry point (using land transport) and initially stayed in the bordering Indian town. Later, they travelled to larger cities within India. Figure 3.1 shows the various destination cities within India where these migrants travelled to for work. Consequently, the migration behaviour observed here may be reflective not just of local or internal migration behaviour, but to some extent also of international migration as traditionally conceived.

\footnotetext{
${ }^{25}$ Confirmed by the local migrant organization.
} 
Figure 3.1: Destination Cities within India where 118 Migrants Work

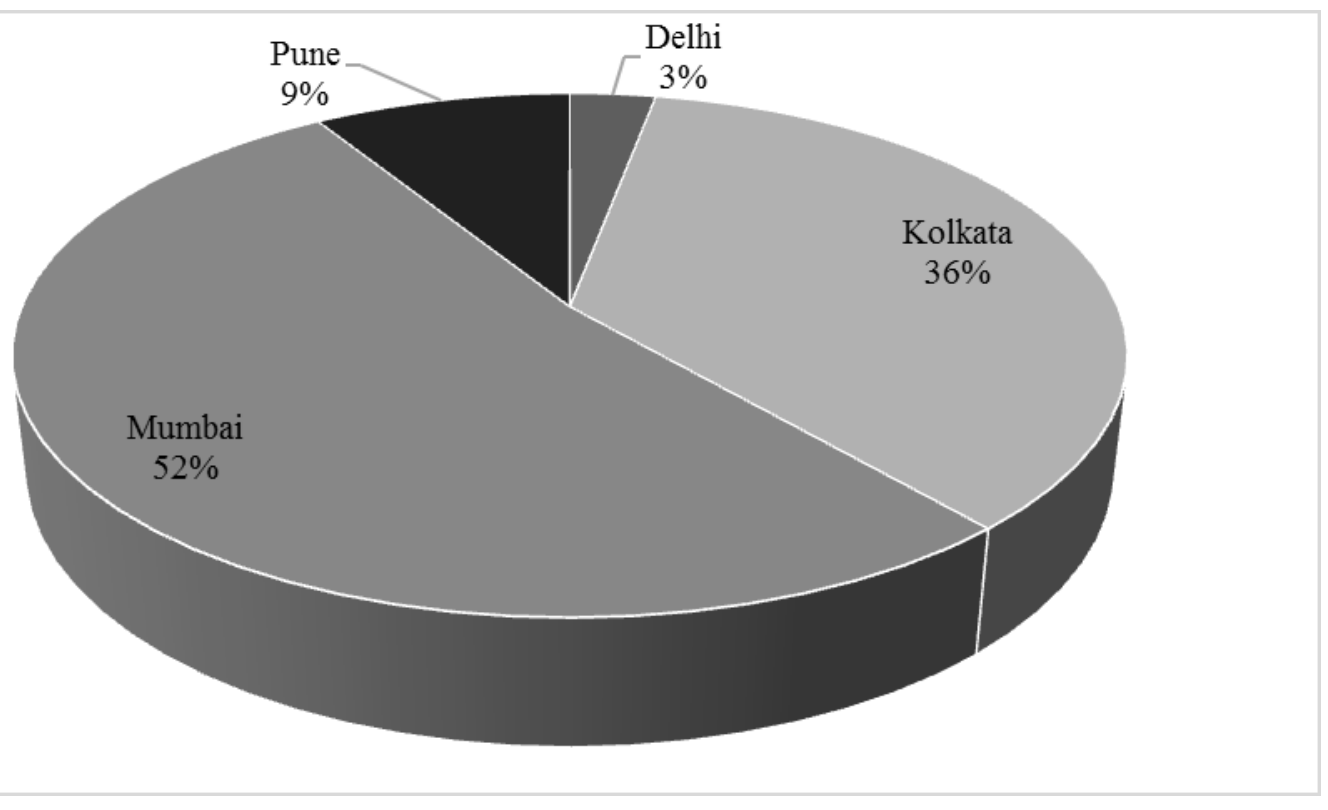

Approximately sixty per cent of the study participants were temporary migrants (those who expressed a strong desire to eventually return home).

Table 3.2: Number of Temporary and Permanent Migrants Originating from Villages A and B

\begin{tabular}{|c|c|c|}
\hline & Number of Temporary Migrants & Number of Permanent Migrants \\
\hline Village A & 16 & 30 \\
\hline Village B & 53 & 19 \\
\hline Total & $\mathbf{6 9}$ & $\mathbf{4 9}$ \\
\hline
\end{tabular}

For the 118 migrants interviewed, the average age of female migrants is 28 years and the average age of male migrants is 32 years. More than 52 per cent of the sample population (male and female migrants) was between the ages of 20 and 30 . The share of the female migrants in the overall study sample was slightly more than 25 per cent. Appendix B.1 provides further statistical characteristics about migrant profiles in both these villages.

Figures 3.2 and 3.3 illustrate the age distribution as well as the marital status of all the female migrants $(n=30)$ and male migrants $(n=88)$ in the study sample $(n=118)$. 
Figure 3.2: All Female Migrants' Marital Status and Age Profile

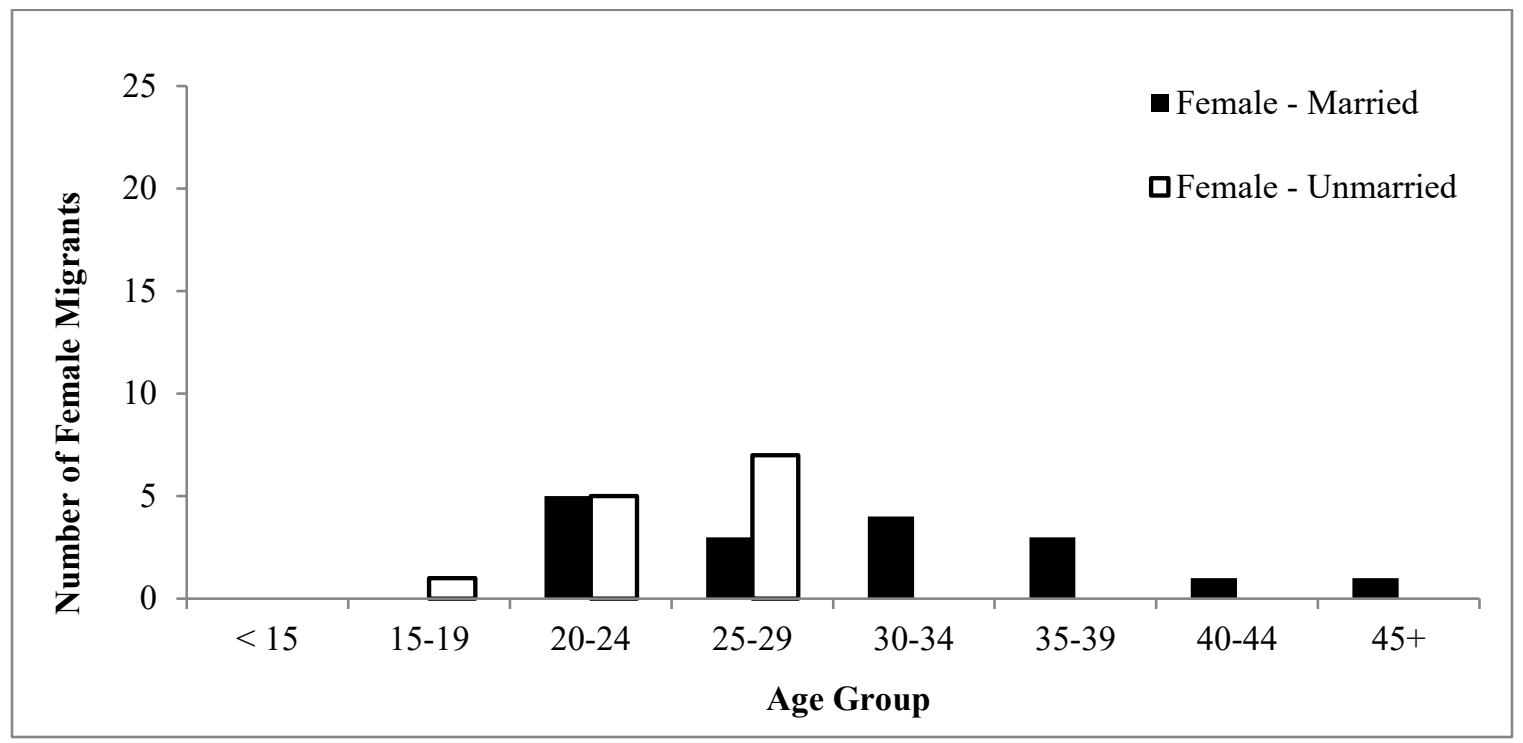

Figure 3.3: All Male Migrants' Marital Status and Age Profile

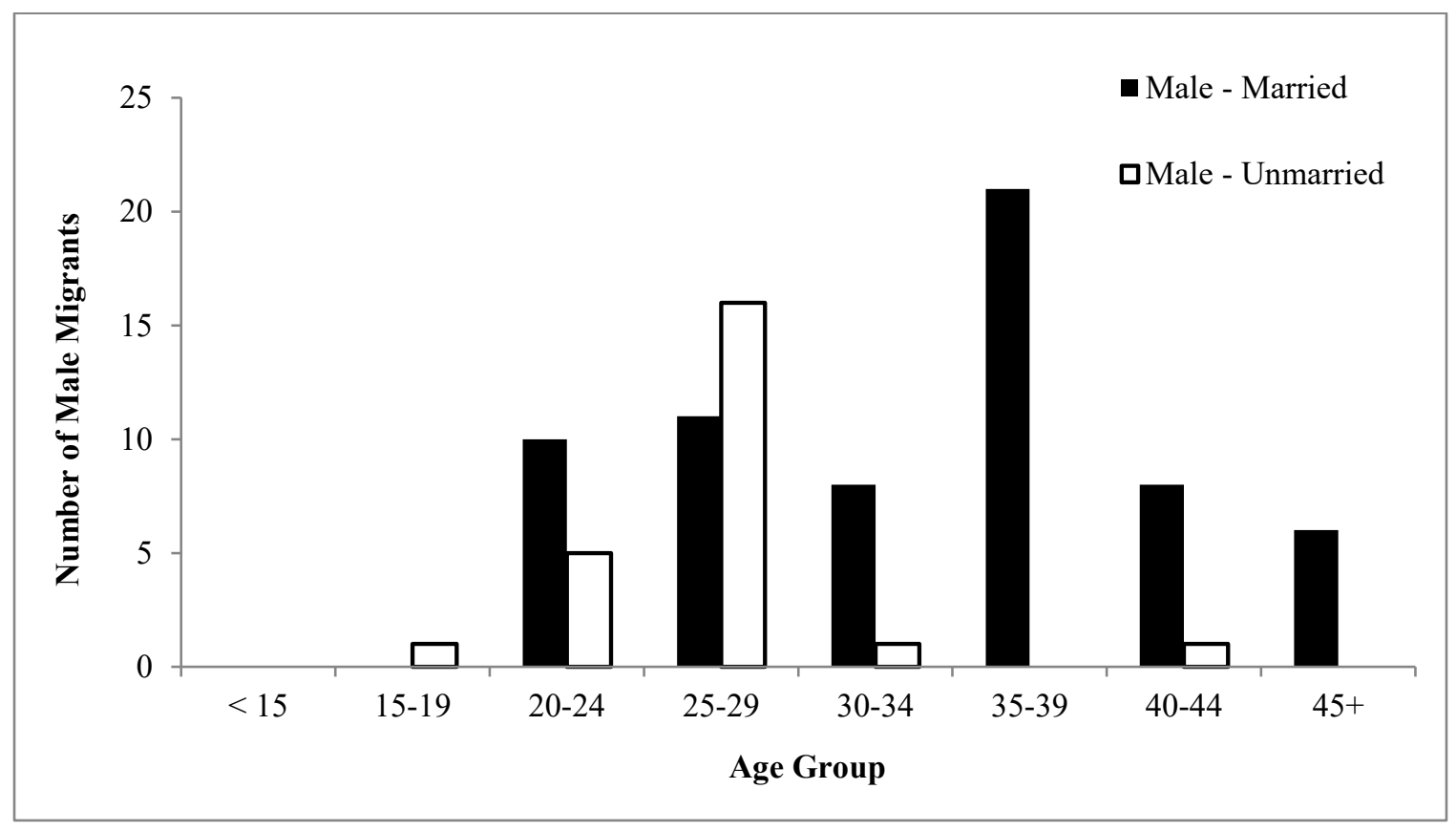

From the above histograms (3.2 and 3.3), some important observations can be further made about the characteristics of the male and female migrants from both villages. In the study sample, the youngest migrant (male and female) is 18 years old, the oldest male migrant is 52 years old and the oldest female migrant is 48 years old. There are no unmarried female migrants above the age of 29. In contrast, there are several unmarried 
male migrants above the age of 29 . Although the sample size is small, this pattern is reflective of the existing cultural perceptions about women's mobility outside the boundaries of their homes. These rural communities are patriarchal in nature and are dominated by traditional values where women are viewed as passive recipients as opposed to active participants in the household decision-making process in both their paternal and matrimonial homes and are generally discouraged from migrating internationally in the absence of an accompanying male adult (Debnath \& Selim, 2009). However, information from in-depth interviews confirmed that in the absence of alternatives (for instance, no older male child) coupled with the necessity of meeting basic consumption needs as well as a way to diversify household income sources, some families with female adult children are supportive of their unmarried daughters migrating abroad. During in-depth interviews, unmarried female migrants $(n=13)$ indicated that unlike their male migrant counterparts, they often do not have much say in the way the remittance amounts that they send back to their parents are used.

As mentioned earlier, the two villages examined here do not differ significantly in terms of their socio-economic conditions and their cultural norms. As a result, factors affecting women's migratory patterns, the barriers they encounter, as well as their general remitting behaviour are similar between the two villages. On average, the female migrants from both villages reported similar responses to the qualitative survey questions examining the specific gender dynamics within their households.

Another similarity of the two villages is that they are both vulnerable to dramatic fluctuations in the prices of agricultural products and cash crops (Bäckman \& Sumelius, 2009), so there is no guarantee that these agrarian households will generate the same level of income year over year. Migration introduces greater stability in their household earnings 
since it provides them with another source of income when the return to farming is less than expected. During the in-depth interviews, migrants from both villages were asked if they would opt for any type of migration (internal or international) if their local economy improved and provided them with more income opportunities. Despite facing similar price fluctuations, the migrants from the two villages responded differently to this question. The migrants originating from Village A (where disaster is less frequent and causes less disruption to life) stated that they would prefer to stay in their place of origin if they had other (non-agricultural) economic opportunities within their locality to earn a decent and stable income.

In contrast, migrants from Village B responded that even if there were alternate sources of economic opportunities available to them within their village, it would be difficult for them to continue those activities unless the frequency and severity of natural disasters was reduced. The migrant population of Village B noted that they have been encountering unpredictable climate stresses and shocks, particularly in the form of excessive heat (leading to droughts), hailstorms and floods making it difficult for them to continue with their day to day lives as well as agricultural or other potentially different economic activities. Natural calamities are detrimental for subsistence agriculture as well as growing cash crops, the main economic activity of the villagers. In an attempt to address these sudden and frequent income shocks and to smooth household consumption levels, many families in Village B have responded by diversifying their sources of income through international migration. What is interesting is that despite facing similar market fluctuations, the additional climate-related shocks in Village B are sufficiently large so as to change significantly the local perceptions and interview responses regarding the capacity of the local economy to provide alternatives to the risk diversification strategy of migration. 
Most of the climate change and migration literature refers to this type of migration as an adaptive strategy to mitigate the impact of climate change (IOM, 2010; McLeman \& Smit, 2006). Male and female migrants from both villages provided similar responses to this question.

The cost of migration was also a crucial factor for these migrants when deciding between internal versus international migration. Since both villages are located close to some of the border entry points to India, their travelling costs to India (international) are cheaper compared to other Bangladeshis living in non-border areas. This finding is consistent with claims in the existing literature that almost 80 per cent of identified SouthSouth migration takes place between countries with contiguous borders (Ratha \& Shaw, 2007).

Lastly, access to informal networks of migrants in the destination country reduces the costs and uncertainties associated with international migration. Fifty per cent of the migrants interviewed in this study mentioned that they have acted as a 'facilitator' in helping at least one person from their village to migrate to the same location or city as themselves. For potential migrants, having an established informal network mitigated the risk of falling into the hands of human smugglers and human traffickers. ${ }^{26}$ The power of

\footnotetext{
${ }^{26}$ Human Trafficking is defined as "the recruitment, transportation, transfer, harbouring or receipt of persons, by means of the threat or use of force or other forms of coercion, of abduction, of fraud, of deception, of the abuse of power or of a position of vulnerability or of the giving or receiving of payments or benefits to achieve the consent of a person having control over another person, for the purpose of exploitation" (Trafficking in Persons, 2016). Human Smuggling, contrary to trafficking, does not require an element of exploitation, coercion, or violation of human rights. It is defined as "the procurement, in order to obtain, directly or indirectly, a financial or other material benefit, of the illegal entry of a person into a State Party of which the person is not a national or a permanent resident" (Smuggling, 2016).
} 
informal networks in facilitating further migration is a well-accepted fact within the migration literature (Ratha \& Shaw, 2007; The World Bank, 2006). ${ }^{27}$

Established informal networks play an even greater role for potential female migrants, particularly for those who are considering migrating on their own (single women) or who are migrating alone to join their husbands abroad. Most of the female migrants from Village A and Village B reported that their migration-related travel experiences are very different compared to those of male migrants, despite using the exact same travel route and arrangements. The majority of the female migrants in the study reported that they are frequently harassed by the border police despite having all their travel documents in order. For younger, unmarried female migrants, these concerns are more poignant. These females have to budget for extra travel time while crossing the borders as the border officials (mostly males) put them in the waiting areas for longer hours while they clear the documents of male travelers.

\subsection{Results and Discussion}

Using primary data collected from Villages A and B, this section of the chapter discusses the responsiveness of remittances in the aftermath of natural disasters along with the role of various migrant characteristics (such as sex, age, marital status, duration of migration) on remittance-sending behaviour. In order to do so, the regression is estimated for the following specification:

\section{Monthly Remittances $=\beta_{0}+\beta_{1}$ Migrant Sex $+\beta_{2}$ Disaster Dummy $+\beta_{3}$ Female*Disaster Dummy $+\beta_{4}$ Migrant Returns Post Disaster $+\beta_{5}$ Female*Migrant Returns Post Disaster $+\beta_{6}$ Net Household Income + $\beta_{7}$ Number of Migrants in the Family $+\beta_{8}$ Migrant's Marital Status +}

\footnotetext{
${ }^{27}$ It is important to note that there is a possibility that the legal status of the migrants in the host country may also have an effect on migration and remittance behaviour. However, this status cannot be identified in this research for reasons of confidentiality.
} 


\section{$\beta_{9}$ Migrant's Age $+\beta_{10}$ (Migrant's Age $)^{2}+\beta_{11}$ Temporary Migrants + $\beta_{12}$ Education $+\beta_{13}$ Female $*$ Married + Error}

In the above equation, Monthly Remittances is the amount of monthly remittances sent by migrants from abroad, Migrant Sex is a dummy variable coded as 1 for male, Disaster Dummy is a dummy variable coded as 1 to capture the occurrence of a natural disaster, Migrant Returns Post Disaster is a dummy variable coded as 1 when migrants (male and female) return home following a natural disaster affecting their households in the village, Female*Migrant Returns Post Disaster is an interactive dummy variable coded as 1 when female migrants return home following a natural disaster affecting their households, Net Household Income is the household income (net of remittances) of a migrant household in a migrant's village, Number of Migrants in the Family captures the number of migrants from the same household living/working abroad, Migrant's Marital Status is a dummy variable coded as 1 when the migrant in the sample is married, Migrant's Age represents migrant's age, (Migrant's Age) ${ }^{2}$ is the quadratic form of migrant's age, Temporary Migrants represent the migrants who have migrated on a temporary basis, Education represents the years of formal schooling of the migrant and Female*Married is an interactive dummy variable coded as 1 for married female migrants.

Table 3.3 shows the regression results for the entire study population $(n=118)$. The model presented here focuses on migrants' remitting responses in the aftermath of natural disasters affecting their homes. The model also tests for gender-specific remitting trends in the full sample using interactive terms to distinguish between the remitting decisions of male and female in the event of a natural disaster (female migrants*disaster dummy) and when they return home after a natural disaster (female migrants*those who returned home following a disaster). 
The dataset was checked to confirm that there were no serious problems of multicollinearity. The variance inflation factors (VIF) for the regressions were examined and aside from the age variable (which appears in both its linear and quadratic form, and thus is multicollinear by construction) and a few of the interactive variables, there were no VIF scores above 10, and most were below 5. For the interactive variables with a high VIF value, supplementary estimations were run to determine whether their presence was distorting the coefficient estimates of other variables. Consequently, some hypotheses could not be tested formally. For example, the hypothesis that the impact of age on remittances was different for men and women could not be tested since the variable interacting gender with age, though did not itself have a statistically significant coefficient estimate, did alter the significance of the coefficient estimate for the migrant sex variable. Similarly, the term interacting migrant's sex with household income was also dropped. Since the Breusch-Pagan / Cook-Weisberg test indicated that there was heteroscedasticity, the standard White correction was used to adjust the standard errors and produce the robust standard errors. Table 3.3 presents the results of the parsimonious model as well as the full model. The full model includes two other variables (migrant's education and an interactive term predicting the remitting trend of married female migrants) that appear to have no statistical significance and were thus dropped from the parsimonious version. The analysis of Table 3.3 that follows hereafter refers to the coefficients under the parsimonious model. 
Table 3.3: Regression Results for all Migrants in both Villages $(n=118)$

\begin{tabular}{|c|c|c|}
\hline Variables $^{\dagger}$ & Parsimonious Model & Full Model \\
\hline & $\begin{array}{l}\text { Estimated Coefficient } \\
\text { (t-statistics in brackets) }\end{array}$ & $\begin{array}{l}\text { Estimated Coefficient } \\
\text { (t-statistics in brackets) }\end{array}$ \\
\hline Migrant Sex Dummy (Male $=1$, Female $=0$ ) & $\begin{array}{l}-1935.9 * * * \\
(-2.81)\end{array}$ & $\begin{array}{l}-2054.4^{* * *} \\
(-2.25)\end{array}$ \\
\hline $\begin{array}{l}\text { Disaster Dummy } \quad \text { (Disaster }=1, \quad \text { No } \\
\text { Disaster }=0 \text { ) }\end{array}$ & $\begin{array}{l}2814.2 * * * \\
(4.62)\end{array}$ & $\begin{array}{l}2837.5 * * * \\
(4.69)\end{array}$ \\
\hline Female Migrants*Disaster Dummy & $\begin{array}{l}-1960 * * * \\
(-2.82)\end{array}$ & $\begin{array}{l}-1992.5 * * * \\
(-2.81)\end{array}$ \\
\hline Migrants Returning Home Post Disaster & $\begin{array}{l}-489.7^{*} \\
(-1.63)\end{array}$ & $\begin{array}{l}-467.9 \\
(-1.52)\end{array}$ \\
\hline $\begin{array}{l}\text { Female Migrants*Returning Home Post } \\
\text { Disaster }\end{array}$ & $\begin{array}{l}-1405.9^{* *} \\
(1.99)\end{array}$ & $\begin{array}{l}-1358.2 * * \\
(-1.93)\end{array}$ \\
\hline $\begin{array}{l}\text { Household Income (net of remittances) of } \\
\text { Left-behind Households }\end{array}$ & $\begin{array}{l}-0.52 * * * \\
(-2.66)\end{array}$ & $\begin{array}{l}-0.528 * * * \\
(-2.59)\end{array}$ \\
\hline Number of Migrants from Same Household & $\begin{array}{l}-689.6^{* * *} \\
(-2.52)\end{array}$ & $\begin{array}{l}-675.2 * * * \\
(-2.42)\end{array}$ \\
\hline Married Migrants & $\begin{array}{l}-743.4 * * \\
(-1.96)\end{array}$ & $\begin{array}{l}-664.8 * * \\
(-1.95)\end{array}$ \\
\hline Migrant Age & $\begin{array}{l}404.9 * * * \\
(3.17)\end{array}$ & $\begin{array}{l}404.6^{* * *} \\
(3.15)\end{array}$ \\
\hline Migrant $\mathrm{Age}^{2}$ & $\begin{array}{l}-5.8 * * * \\
(-3.43)\end{array}$ & $\begin{array}{l}-5.8 * * * \\
(-3.41)\end{array}$ \\
\hline Temporary Migrants & $\begin{array}{l}1464.6^{* * *} \\
(2.54)\end{array}$ & $\begin{array}{l}1491 * * * \\
(2.60)\end{array}$ \\
\hline Education (years of formal schooling) & - & $\begin{array}{c}25.3 \\
(0.49)\end{array}$ \\
\hline Female migrants * Married & - & $\begin{array}{l}-169.5 \\
(-0.23) \\
\end{array}$ \\
\hline Constant & 575.3 & 589.3 \\
\hline Observations & 118 & 118 \\
\hline R-squared & 0.81 & 0.81 \\
\hline
\end{tabular}

$\dagger$ Dependent Variable: Monthly remittances sent by migrants. All amounts presented in the table are expressed in Taka (Bangladesh Currency). Rate of currency conversion used: US $\$ 1=$ Taka 78 Note: $* * * p<0.01 ; *$ p $<0.05 ; * p<0.1$

The findings of this study are consistent with the large majority of the remittance literature that claims that remittances increase in the aftermath of a natural disaster (Benson \& Clay, 2004; Hicks, 1993; Mohapatra et al., 2012; The World Bank, 2006; Yang, 2007). The regression results in Table 3.3 indicate that migrants remit significantly more in the aftermath of natural disasters affecting their home communities. ${ }^{28}$

${ }^{28}$ The OLS estimation results with uncorrected standard errors produced very similar results to the robust error model in terms of statistical significance. All variables with statistically significant coefficient estimates in the robust estimation were also statistically significant at the $10 \%$ one-tailed test or better as well, with some coefficient estimates having slightly higher $\mathrm{p}$-values and others with slightly lower $\mathrm{p}$-values. 
However, gender plays a vital role in influencing a migrant's remitting behaviour both in general and in the aftermath of a disaster at home. On average, the raw data (unadjusted for individual characteristics such as age or education) indicate that women remitted approximately Taka 6,200 (US\$79) per month, while men remitted just under Taka 5,600 (US\$72). A standard t-test of sample means indicates that these amounts are not statistically distinct. However, data from in-depth interviews indicated that male migrants from both villages worked mostly as factory workers, small shop owners or as drivers in the transportation sector compared to their female counterparts who were predominantly employed in lower paid jobs such as brick kiln workers or domestic helpers. For the study population, migrant women's average monthly income is approximately Taka 7,000 (US\$90) whereas migrant men's average monthly income is approximately Taka 13,500 (US\$173). ${ }^{29}$ Therefore, on average, female migrants were remitting almost 90 per cent of their income while men were remitting just over 40 per cent. Furthermore, this simple comparison does not take into account the other individual and family characteristics that may systematically differ between men and women, hence the need for regression analysis to identify any conditional gender differences in remitting behaviour.

Adjusting for characteristics such as age and education, women appear even more generous than suggested by the raw data. The estimated coefficients in the model indicate that in the absence of a disaster, women migrants remit significantly more on average (Taka 1,936 per month, or roughly US\$25) than men. However, in the aftermath of a natural disaster men appear more generous in their response, remitting on average Taka 2,814

\footnotetext{
${ }^{29}$ The information on migrant's average monthly income was obtained from the local migrant organization and further verified by information collected from a smaller subset of migrants from both villages.
} 
(US\$ 36) more per month, while women remit Taka 854 (Taka 2,814 - Taka 1,960= Taka 854 or roughly US\$11) more per month to help their households in the home country to mitigate the adverse financial affects caused by the disaster. ${ }^{30}$ For the average male this response represents an increase in remittances of roughly 50 per cent overall and approximately 21 per cent of income, while for females the corresponding numbers are 14 per cent and 12 per cent. Given the average relative generosity of women migrants, however, it should be noted that after a disaster they are remitting effectively all their income, while men remit in total only 62 per cent of income after a disaster. Therefore, while women remit less compared to men in the event of a disaster, they are also more constrained by lower average incomes and prior generosity in terms of their response. Consequently, by examining women's remittance patterns in the context of their average incomes, it appears that in the event of a disaster many women remit nearly all their average disposable income (average income less average remittances in the absence of a disaster) while men respond by sending only 36 per cent of their average post-remittance income.

Men and women also have different responsibilities within their households as well as varying degrees of expectations from their families. Their remitting patterns are reflective of these factors. For instance, men and women's remitting behaviour differ depending on whether they are accompanied by their spouse or other family members. These findings are reinforced by the information collected through in-depth interviews with the migrants, in which various underlying dynamics affecting women's remitting

\footnotetext{
30 The remittance response to disasters is simply the coefficient estimate on the disaster dummy variable, which is common to both men and women. For women, however, the estimation permitted the effect to differ from that of men by interacting the disaster dummy with an indicator for a women migrant. For women, therefore, the response to a disaster is given by the general disaster remittance effect plus the coefficient estimate on the interactive term, as shown by the calculation within the text.
} 
behaviour come to light. Interviews revealed that married female migrants who migrate along with their spouses are expected to contribute to the remittance amount being sent to their husband's family back home. Consequently, the amount of remittances that they sent back to their home country is often divided between their own parents' households and their husband's parents' households. In contrast, males in a comparable situation only reported remitting to their own parents/family back home (not to their wives' families). Female respondents indicated that they are hesitant in revealing how much remittances they send to their parents (thus, underreporting the true extent of how much they remit) in the fear that their husbands will disapprove of this and take away or redirect that amount. Although challenging to quantify, it is important to take into consideration these more nuanced socio-cultural factors that affect women's remitting patterns. Furthermore, these concealed or informal flows of remittances go unrecorded and contribute to underestimating the actual inflow of remittances. Based on household surveys and econometric analysis, a 2006 World Bank Report states that "unrecorded flows through informal channels may conservatively add 50 per cent or more to the official recorded flows going into the developing countries" (p. 85).

While some of the remittance amounts may seem very small to outsiders, it must be remembered that migrant remittances are a significant source of support for the families left-behind in these two villages. The statistical results presented here can be placed in context from the accounts gathered from migrants' interviews, where they mentioned that more than 80 per cent of the household income (in their left-behind homes) consists of remittances that they send from abroad.

Another crucial finding of the study is that given the proximity between Bangladesh and India (neighbouring countries), in the aftermath of natural disasters approximately 45 
per cent of the migrants returned home temporarily to rejoin their affected households. Estimated coefficients capturing this behaviour indicate that those migrants who returned home following a disaster remitted less, as they brought back cash with them. ${ }^{31}$ Remitting behaviour of this 45 per cent of migrants is also strongly influenced by gender dynamics. The results in Table 3.3 indicate that male migrants remit Taka 490 (US\$6) less and women remit Taka 1,896 (Taka 1,406 +Taka $490=$ Taka 1,896 , roughly US\$24) less when they intend to return home temporarily after disaster. It should be noted that the coefficient estimate on the returning home variable is only marginally significant, and so any association should be treated with caution. Returning home with savings and sending remittances are interrelated behaviours that characterize ways of accomplishing the same outcome: repatriating earnings to the home (Durand, Kandel, Parrado, \& Massey, 1996). There is a lack of discussion in the existing migration and remittance literature when it comes to analyzing these intricate aspects of remitting behaviour. This observation is even more pronounced in this sample population due to the geographical proximity between migrants' home communities and their host communities. Migrants could opt to travel using land transport, thus reducing the cost of travel for these migrants relative to those migrants who migrated to non-neighbouring countries and whose only option to return home is through air travel (a relatively expensive option).

The regression results also indicate a strong inverse relationship between the amounts that migrants remit and the monthly household income of the family left-behind. As the income of the migrants' households in the origin country increases by Taka 100

\footnotetext{
${ }^{31}$ In-depth interviews confirmed that migrants who return home following a disaster almost always bring back cash with them.
} 
(US\$1.3), the amount remitted by the migrants living abroad decreases by about Taka 52 (US\$0.67), other things remaining equal. This finding is consistent with the existing literature that purports that there is an inverse relationship between the income of the leftbehind households and the level of remittances they receive.

The estimation results also reveal that migrants as a group send less remittances if there are more migrant members from the same household or family working abroad. With more family members working abroad as migrants, migrants can share the responsibility of sending remittances to the family members left-behind. For every additional migrant a household has, the migrant abroad sends Taka 690 (US\$9) less. As can be seen in the gender-specific estimations of Appendix B.2, this effect is also observed when considering the responses of male and female migrants separately - males sent Taka 683 (US\$9) less and females sent Taka 1,070 (US\$14) less. In-depth interviews revealed that for families where a number of siblings from the same household worked abroad, the total amount of remittances being sent home were pooled together by the migrants. Each migrant's share was often based on the level of income in the destination country - the more the income the higher is the share of contribution to remittances. Pooling the amount of remittances needed to be sent home allowed the migrants to build some personal savings and improve their level of consumption in the destination country. During interviews female migrants mentioned that if they had a brother who migrated from the same household, the pressure for them to remit to their paternal households is significantly less.

The regression results from the study also indicate that a migrant's marital status plays a pertinent role in influencing their remitting behaviour. Married migrants remit Taka 743 (US\$9) less than unmarried migrants. As indicated in Appendix B.2, among male migrants, married males remit Taka 635 (US\$8) less than unmarried males and among 
female migrants, married females remit Taka 1,123 (US\$14) less than unmarried females. This pattern is consistent with the fact that during interviews several married migrants indicated that they took their spouses and children with them, thus, it is reasonable that these migrants needed money in the host country to support their immediate families. In contrast, unmarried migrants who left all their family members behind remitted more. These findings echo the results found in other studies on the effect of marital status on migrants' remitting behaviour (Debnath \& Selim, 2009; Gedeshi, 2002; Unheim \& Rowlands, 2012). These findings also indicate that remittances decrease as the size of the migrating family increases (Unheim \& Rowlands, 2012).

Further interesting qualitative observations regarding a migrant's marital status were noted during in-depth interviews. As mentioned in the literature review section, according to Gedeshi (2002), for most married migrants who left their spouses and children behind, the primary recipients of their remittances are their spouses and children in the country of origin. However, it is important to note that for Bangladeshi communities, the gender dynamics within migrant households play a significant role in determining who receives the remittances. In the majority of the cases, the study found that the younger the wives of the migrants, the higher the probability that they lived with their husbands' families (in-laws) in a joint family structure. In a joint family structure, the male migrant typically sent remittances to their father (considered the head of the household) and in the absence of the father, remittances were sent to the migrant's mother or brother. In these households, the migrants' wives had no control over how the remittances were spent and had little knowledge of the exact amount of remittances being received. Household decisions were made solely by the male migrant and the remittance recipient (the migrant's father or mother or brother). In contrast, for families where the migrants' wives (mostly 
above 40 years old) did not live with their in-laws, the husbands sent remittances directly to their wives. For these women, the remittances served as a source of financial empowerment giving them more local decision-making power as they act as the de-facto household head in the absence of their husbands. However, it is important to note that when the husbands returned home they automatically resumed their role as the head of the household. Previous studies examining the impact of male migration on their wives leftbehind arrived at similar conclusions as this study (Debnath \& Selim, 2009).

In contrast to married male migrants, most married female migrants (mostly temporary migrants) who left their husbands and children behind sent their remittances directly to their husbands regardless of the presence of other family members. This remitting pattern was observed for female migrants from both villages. This remitting behaviour is also reflective of the overarching gender and power relations that are prevalent within Bangladeshi society where men control not just the majority of the household's material resources but also the labour of women and children (Kabeer, 1994).

Age is also correlated significantly with the remitting decisions of migrants. As the age of a migrant increases, so do the amounts sent home. The results in Table 3.3 indicate that the peak occurs at about 35 years of age. Migrants above the age of 35 exhibit a declining trend in the amount they remit. When remitting behaviour of male and female migrants are separately considered in Appendix B.2, a similar trend is observed around age 34 for both groups. This overall non-linear relationship between age and remitting behaviour is in line with the results found by Unheim and Rowlands (2012) and Merkle and Zimmermann (1992) in their analysis of Canadian and German migrant data respectively. 
This study also examined the remitting behaviour of temporary versus permanent migrants. Estimation results in Table 3.3 indicate that temporary migrants remit Taka 1,465 (US\$19) more than permanent migrants. When the remitting behaviour of male and female temporary migrants is separately considered in Appendix B.2, a similar trend is observed. Male temporary migrants remit Taka 1,491 (US\$19) more than those who are permanent, and female temporary migrants remit Taka 1,500 (US\$19) more than those who are permanent. This result is consistent with the data collected from in-depth interviews, which reveal that migrants who have the intention to return home tend to remit more. This finding is also supported by other remittance studies examining the relationship between remittance flows and migrant's duration of stay in the country of destination (Dustmann \& Mestres, 2010; Ramamurthy, 2003).

In some micro-level remittance studies, income is also typically included as an important explanatory variable. While average data for the sample was collected from a few key interviews (that was also corroborated by information from the local migrant organization), obtaining consistently the actual income for all remitters was not possible. Since the absence of the income variable could lead to endogeneity due to omitted variable bias, education was included as an instrument or proxy for income. The results (Table 3.3 full model) show that there is no statistically significant impact of a migrant's education on his or her remitting behaviour, and the results for the other variables are stable regardless of whether the education variable is included or not. This observation is consistent with the labour market characteristics of the study population. All the participants of this study are unskilled and semi-skilled migrants who completed on average less than six years of formal education and were generally engaged in similar occupations in the host country. 
An in-depth analysis of the interview responses indicates that migrant families within both villages tend to form stronger bonds with other migrant families. They use these informal groups to engage in recreational activities as well as to discuss their common problems. The affinity to form and participate in these small groups is stronger among women. For instance, female migrant workers as well as wives of migrant male workers have their own informal networks, which act as support groups. Nonetheless, male migrants reported that most of their friends in their country of origin are fellow migrant workers. With the interventions of the local migrant organization working on raising awareness of migrants' rights and bringing together migrant families through community events, these sorts of support groups are becoming more common for both male and female migrants.

\subsection{Sensitivity Analysis}

\subsubsection{Parsimonious Model vs. Full Model}

Table 3.3 presents the estimation results of the parsimonious model as well as the full model. The results indicate that there are no significant qualitative differences between these two estimations. Both the parsimonious model and full model indicate that in the aftermath of natural disasters, migrants respond by remitting more. Furthermore, migrants who return home following a disaster remit less, as they tend to bring back cash with them. While the direction of this effect is consistent under both the models, the coefficient estimates are only (marginally) statistically significant in the parsimonious model.

As discussed in the preceding section, the null hypothesis that a migrant's years of formal education do not have an impact on his or her remitting trend is accepted since the coefficient determining this relationship is statistically insignificant (Table 3.3 full model). Similarly, the statistically insignificant coefficient for the female married migrants (Table 
3.3 full model) indicates that they do not have different remitting patterns than unmarried female migrants.

\subsubsection{Log-Log Model}

Further sensitivity analysis examined the results of logging some of the variables in the parsimonious model. A log-log regression is estimated for the following specification:

Log Monthly Remittances $=\beta_{0}+\beta_{1} \log$ Net Household Income $+\beta_{2}$ Disaster Dummy $+\beta_{3}$ Female $*$ Disaster Dummy $+\beta_{4}$ Migrant Returns Post Disaster $+\beta_{5}$ Female Migrant Returns Post Disaster $+\beta_{6}$ Migrant Sex $+\beta_{7}$ Number of Migrants in the Family $+\beta_{8}$ Migrant's Marital Status $+\beta_{9}$ Migrant's Age $+\beta_{10}$ (Migrant's Age) ${ }^{2}+\beta_{11}$ Temporary

$$
\text { Migrants + Error }
$$

Table 3.4: Log-log Model - Regression Results for all Migrants in both Villages $(n=118)$

\begin{tabular}{|l|c|}
\hline \multicolumn{1}{|c|}{ Variables $^{\dagger}$} & Log Version of the Parsimonious Model \\
\hline & $\begin{array}{c}\text { Estimated Coefficient } \\
\text { (t-statistics in brackets) }\end{array}$ \\
\hline Log Household Income (net of remittances) of Left- & $-0.12^{* * *}$ \\
behind Households & $(-2.92)$ \\
\hline Disaster Dummy (Disaster =1, No Disaster=0) & $0.59^{* * *}$ \\
& $(6.96)$ \\
\hline Female Migrants * Disaster Dummy & $-0.26^{* *}$ \\
& $(-1.97)$ \\
\hline Migrants Returning Home Post Disaster & $-0.10^{* *}$ \\
& $(-1.98)$ \\
\hline Female Migrants * Returning Home Post Disaster & $-0.29^{* *}$ \\
& $(1.95)$ \\
\hline Migrant Sex Dummy (Male=1, Female=0) & $-0.26^{*}$ \\
& $(-1.90)$ \\
\hline Number of Migrants from Same Household & $-0.05^{* *}$ \\
& $(-1.96)$ \\
\hline Married Migrants & -0.05 \\
& $(-0.76)$ \\
\hline Migrant Age & $0.05^{* *}$ \\
& $(1.96)$ \\
\hline Migrant Age ${ }^{2}$ & $-0.009^{* * *}$ \\
& $(-2.43)$ \\
\hline Temporary Migrants & $0.28^{* * *}$ \\
& $(3.40)$ \\
\hline Constant & 8.49 \\
& $(14.9)$ \\
\hline Observations & 118 \\
\hline R-squared & 0.86 \\
\hline
\end{tabular}


† Dependent Variable: Log of monthly remittances sent by migrants. All amounts are expressed in Taka (Bangladesh Currency). Rate of currency conversion used: US\$1 = Taka 78

Note: ${ }^{* * *} \mathrm{p}<0.01 ; * * \mathrm{p}<0.05 ;{ }^{*} \mathrm{p}<0.1$

The results of the log-log model in Table 3.4 tell a similar narrative as the unlogged parsimonious model in Table 3.3. The results in Table 3.4 indicate that in the aftermath of a natural disaster, remittances increase significantly. Remittances sent are also responsive to changes in the migrant's net household income in the country of origin. Migrants respond by sending 0.12 per cent less remittances when their net household income in the country of origin increases by 1 per cent. Similarly, migrants returning home following a disaster remit 11 per cent less than those who stay back in the host country.

The overall results in Table 3.4 indicate similar patterns of response (increase or decrease in remittances) as predicted by the parsimonious model. However, compared to the parsimonious model, the coefficient estimates predicting the remitting behaviour of married migrants are statistically insignificant in the log-log model. Most of the results however remain qualitatively similar regardless of whether a strictly linear or a semilog version of the equation is used.

Appendix B.3 presents the estimation results of the parsimonious model when ran on the two villages separately. As stated earlier, Village B is more susceptible to frequent and severe disasters compared to Village A that experiences infrequent disasters. The results indicate that following a disaster, migrants in both villages respond similarly to help their left-behind households - they respond by sending more remittances. However, migrants from Village B remit more than those from Village A. Village B migrants remit Taka 2,724 (Taka 3,910 - Taka 1,186, roughly US\$35) more per month than Village A migrants. The qualitative effects of other variables on the remitting trends are consistent with those reported in Table 3.3. 
To investigate the effects of the different villages two additional estimation approaches were used. The parsimonious model is re-estimated with a village fixed effect, which indicates that Village B remittances are about Taka 760 more than Village A. The other variables in the model have similar coefficient estimates and levels of statistical significance with the exception of the indicator that women have returned to the village after a disaster. With the village-specific fixed effect, women returning after a disaster no longer has a statistically significant coefficient estimate. Further investigation indicates that in Village B only 12 per cent of women returned compared to 77 per cent in Village A. Overall though, the effect of disasters on remittances remained similar to the effects of the main model.

The second approach to examining village differences clusters the standard errors using different village-specific distributions. The estimations (using the "cluster" option in Stata) generate changes in the standard errors and the p-values — while the standard errors often decrease, the confidence intervals become smaller and the p-values lower. The coefficient estimate for the disaster dummy variable remains statistically significant, providing more evidence of the robustness of its role in inducing additional remittances.

\subsection{Conclusion}

Based on a unique primary dataset, this research is one of the first studies of its kind examining responsiveness of remittances sent by Bangladeshi migrants in the aftermath of natural disasters, particularly through a gender lens. The two villages studied here have similar socio-economic conditions as well as cultural and traditional values. The main difference between the two villages is their susceptibility to natural disasters. Since the study sample of 118 is representative of the overall migrant population as well as the 
general community in these two villages, the findings of the study can also be attributed to both villages.

The study found that remittances are strongly responsive to natural disasters. Post disaster, migrants respond by remitting more to help their families at home, presumably to assist them to recover. Gender plays a significant role in influencing the remitting trends and behaviour of migrants. Female and male migrants respond significantly differently preand post disasters. Results also indicate that migrant characteristics such as age, marital status, number of migrants from the same household, duration of stay in the host country, tendency to return home following a disaster, are all crucial factors in influencing their remitting behaviour in the aftermath of a disaster affecting their place of origin.

The empirical results, coupled with the qualitative analysis presented in this chapter, highlight some inherently interesting trends and household gender dynamics that strongly influence migrants' remitting patterns. The existing gender roles and inequalities within the households as well as the broader society play a vital role in deciding who migrates and why, the barriers to migration, amount of remittances sent and how they are spent. The findings of this study highlight and expand on some of the more intricate gender dynamics that are at play.

Furthermore, findings from this dataset conformed closely to the expectations of the migration and remittance literature as well as the claims arising from the NELM theory. Households in the disaster-prone village adopted labour migration as a risk-mitigation strategy and remittances formed a significant portion of the household income.

The study focused on the Bangladesh-India migration corridor, which is the third largest migration corridor in the world preceded by the Mexico and US corridor and the Russia and Ukraine corridor (The World Bank, 2015). However, it is important to 
recognize that the sample size $(\mathrm{n}=118)$ studied in this chapter is relatively small and included migrants belonging to the semi-skilled and unskilled category; hence, without further analysis, it would be difficult to ascertain if the patterns observed for this group of migrants can be attributed to other groups of international migrants from Bangladesh such as highly skilled migrants. Further research using a larger sample size needs to be conducted to confirm if these findings remain relevant for the majority of Bangladeshi international migrants hailing from different parts of the country and travelling to nonneighbouring destination countries.

Finally, this chapter provides some insights relevant to the study of climate change. People living in vulnerable locations will increasingly have to appeal to migration and remittances as coping mechanisms in the face of more frequent extreme weather events. The research presented here indicates that migrants do respond to such events by adjusting their remittance behaviour in the face of disasters at home. Future research may also shed light on how households respond over time to the higher frequency of weather-induced calamities, and how they integrate these events into their migration and remittance decisions. 


\section{Appendix B}

\section{B.1 Summary Statistics of Migrants in Village A and Village B}

\begin{tabular}{|c|c|c|c|}
\hline $\begin{array}{l}\text { Village A } \\
\text { Variable Name }\end{array}$ & $\begin{array}{l}\text { No. of } \\
\text { Obs. }\end{array}$ & Mean & Std. Dev. \\
\hline No. of Migrants & 46 & 1.4 & 0.6 \\
\hline $\begin{array}{l}\text { No. of Female } \\
\text { Migrants } \\
\text { (Dummy variable } \\
\text { coded as } 0 \text { ) }\end{array}$ & 13 & 0 & 0 \\
\hline $\begin{array}{l}\text { No. of Male } \\
\text { Migrants } \\
\text { (Dummy variable } \\
\text { coded as } 1 \text { ) }\end{array}$ & 33 & 1 & 0 \\
\hline All Migrant Age & 46 & 30.7 & 8.4 \\
\hline $\begin{array}{ll}\text { Female Migrant } \\
\text { Age }\end{array}$ & 13 & 27 & 8.3 \\
\hline Male Migrant Age & 33 & 32.1 & 8.1 \\
\hline $\begin{array}{l}\text { No. of Years of } \\
\text { Formal Education }\end{array}$ & 46 & 5.9 & 2.5 \\
\hline $\begin{array}{l}\text { Monthly } \\
\text { Remittances* }\end{array}$ & 46 & $\begin{array}{c}\text { Taka } \\
3913.6 \\
\text { (US\$ } \\
50) \\
\end{array}$ & 2088.6 \\
\hline $\begin{array}{l}\text { Monthly } \\
\text { Household } \\
\text { Income (incl. } \\
\text { remittances) }\end{array}$ & 46 & $\begin{array}{c}\text { Taka } \\
4954.4 \\
\text { (US\$ } \\
64)\end{array}$ & 1881.2 \\
\hline $\begin{array}{l}\text { Net Monthly } \\
\text { Household } \\
\text { Income (excl. } \\
\text { remittances) }\end{array}$ & 46 & $\begin{array}{c}\text { Taka } \\
1053.9 \\
\text { (US\$ } \\
14)\end{array}$ & 754.2 \\
\hline
\end{tabular}

\begin{tabular}{|c|c|c|c|}
\hline $\begin{array}{l}\text { Village B } \\
\text { Variable Name }\end{array}$ & $\begin{array}{l}\text { No. of } \\
\text { Obs. }\end{array}$ & Mean & Std. Dev. \\
\hline No. of Migrants & 72 & 1.3 & 0.6 \\
\hline $\begin{array}{l}\text { No. of Female } \\
\text { Migrants (Dummy } \\
\text { variable coded as } \\
\text { 0) }\end{array}$ & 17 & 0 & 0 \\
\hline $\begin{array}{l}\text { No. of Male } \\
\text { Migrants } \\
\text { (Dummy variable } \\
\text { coded as 1) }\end{array}$ & 55 & 1 & 0 \\
\hline All Migrant Age & 72 & 30.5 & 7.0 \\
\hline $\begin{array}{l}\text { Female Migrant } \\
\text { Age }\end{array}$ & 17 & 28.2 & 4.3 \\
\hline Male Migrant Age & 55 & 31.3 & 7.5 \\
\hline $\begin{array}{l}\text { No. of Years of } \\
\text { Formal Education }\end{array}$ & 72 & 6.2 & 2.9 \\
\hline $\begin{array}{l}\text { Monthly } \\
\text { Remittances* }\end{array}$ & 72 & $\begin{array}{c}\text { Taka } \\
6904.2 \\
\text { (US\$ } \\
88) \\
\end{array}$ & 2958.4 \\
\hline $\begin{array}{l}\text { Monthly } \\
\text { Household } \\
\text { Income (incl. } \\
\text { remittances) }\end{array}$ & 72 & $\begin{array}{c}\text { Taka } \\
7686.8 \\
\text { (US\$ } \\
98 \text { ) }\end{array}$ & 2823.7 \\
\hline $\begin{array}{l}\text { Net Monthly } \\
\text { Household } \\
\text { Income (excl. } \\
\text { remittances) }\end{array}$ & 72 & $\begin{array}{l}\text { Taka } \\
782.6 \\
\text { (US\$ } \\
10)\end{array}$ & 353.9 \\
\hline
\end{tabular}

*Average monthly remittances of all migrants in both Village A and Village B is Taka 5,738 (US\$74). 


\section{B.2 Regression Results when the Parsimonious Model is Separately Ran for All Male $(n=88)$ and Female Migrants $(n=30)$ in both Villages}

\begin{tabular}{|c|c|c|}
\hline Variables $^{\dagger}$ & $\begin{array}{l}\text { All Male Migrants from } \\
\text { both Villages }\end{array}$ & $\begin{array}{l}\text { All Female Migrants } \\
\text { from both Villages }\end{array}$ \\
\hline & $\begin{array}{c}\text { Estimated Coefficient } \\
\text { (t-stat in brackets) }\end{array}$ & $\begin{array}{c}\text { Estimated Coefficient } \\
\text { (t-stat in brackets) }\end{array}$ \\
\hline $\begin{array}{l}\text { Disaster Dummy (Disaster }=1, \text { No } \\
\text { Disaster }=0)\end{array}$ & $\begin{array}{l}2799 * * * \\
(4.51) \\
\end{array}$ & $\begin{array}{c}1800.15^{* *} \\
(1.99) \\
\end{array}$ \\
\hline Male Migrants Retuning Home Post Disaster & $\begin{array}{l}-500.5 \\
(-1.66)\end{array}$ & - \\
\hline $\begin{array}{l}\text { Female Migrants Retuning Home Post } \\
\text { Disaster }\end{array}$ & - & $\begin{array}{c}-1546.01 * * * \\
(-2.05) \\
\end{array}$ \\
\hline $\begin{array}{l}\text { Household Income (net of remittances) of } \\
\text { Left-behind Households }\end{array}$ & $\begin{array}{l}-0.45 * * \\
(-1.98) \\
\end{array}$ & $\begin{array}{c}-0.66 * * * \\
(-3.09)\end{array}$ \\
\hline Number of Migrants from Same Household & $\begin{array}{l}-682.6 * * * \\
(-2.46)\end{array}$ & $\begin{array}{l}-1070.16^{* * * *} \\
(-2.60)\end{array}$ \\
\hline Married Migrants & $\begin{array}{l}-634.8 \\
(-1.42) \\
\end{array}$ & $\begin{array}{c}-1123.47 \\
(-1.39) \\
\end{array}$ \\
\hline Migrant Age & $\begin{array}{l}314 * * * \\
(2.17)\end{array}$ & $\begin{array}{c}826.30 * * * \\
(2.34)\end{array}$ \\
\hline Migrant Age $^{2}$ & $\begin{array}{l}-4.6 * * * \\
(-2.47)\end{array}$ & $\begin{array}{c}-12.15^{* * *} \\
(-2.46)\end{array}$ \\
\hline Temporary Migrants & $\begin{array}{l}1491.3 * * * \\
(2.65)\end{array}$ & $\begin{array}{l}1500 * * * \\
(2.61)\end{array}$ \\
\hline Constant & $\begin{array}{l}243.4 \\
(0.10) \\
\end{array}$ & $\begin{array}{c}-4787.09 \\
(-0.98) \\
\end{array}$ \\
\hline Observations & 88 & 30 \\
\hline R-squared & 0.82 & 0.80 \\
\hline
\end{tabular}

${ }^{\dagger}$ Dependent Variable: Monthly remittances sent by migrants. All amounts are expressed in Taka (Bangladesh Currency). Rate of currency conversion used: US\$1=Taka78

Note: $* * * \mathrm{p}<0.01 ; * * \mathrm{p}<0.05 ; * \mathrm{p}<0.1$ 


\section{B.3 Regression Results for Village A and Village B}

\begin{tabular}{|c|c|c|}
\hline Variables $^{\dagger}$ & Village $A$ & Village B \\
\hline & $\begin{array}{c}\text { Estimated Coefficient } \\
\text { (t-stat in brackets) }\end{array}$ & $\begin{array}{c}\text { Estimated Coefficient } \\
\text { (t-stat in brackets) }\end{array}$ \\
\hline $\begin{array}{l}\text { Household Income (net of remittances) of } \\
\text { Left-behind Households }\end{array}$ & $\begin{array}{c}-0.54 * * * \\
(-3.80) \\
\end{array}$ & $\begin{array}{c}-0.06 * * * \\
(-2.08) \\
\end{array}$ \\
\hline Disaster Dummy (Disaster $=1$, No Disaster $=0$ ) & $\begin{array}{l}1185.73 * * * \\
(4.19)\end{array}$ & $\begin{array}{l}3910.26 * * * \\
(8.75)\end{array}$ \\
\hline Female Migrants * Disaster Dummy & $\begin{array}{c}-1057.86 \\
(-1.41) \\
\end{array}$ & $\begin{array}{c}-842.39 * * \\
(-1.92)\end{array}$ \\
\hline Migrants Returning Home Post Disaster & $\begin{array}{r}-272.79 \\
(-1.04) \\
\end{array}$ & $\begin{array}{r}-423.52 \\
(-0.88) \\
\end{array}$ \\
\hline $\begin{array}{l}\text { Female Migrants * Returning Home Post } \\
\text { Disaster }\end{array}$ & $\begin{array}{c}-1291.22 * * * \\
(-2.28) \\
\end{array}$ & $\begin{array}{c}-1359.21 * * * \\
(-3.27) \\
\end{array}$ \\
\hline Migrant Sex Dummy (Male=1, Female $=0)$ & $\begin{array}{l}-1653.27 * * * \\
(-2.93)\end{array}$ & $\begin{array}{l}-444.15 * * * \\
(2.25)\end{array}$ \\
\hline Number of Migrants from Same Household & $\begin{array}{c}-109.98 \\
(-0.47) \\
\end{array}$ & $\begin{array}{c}-1399.49 * * * \\
(-3.38) \\
\end{array}$ \\
\hline Married Migrants & $\begin{array}{r}-204.92 \\
(-0.65) \\
\end{array}$ & $\begin{array}{c}-1401.35 * * * \\
(-3.21)\end{array}$ \\
\hline Migrant Age & $\begin{array}{c}152.81^{* *} \\
(1.96)\end{array}$ & $\begin{array}{c}750.26 * * * \\
(3.37)\end{array}$ \\
\hline Migrant Age ${ }^{2}$ & $\begin{array}{c}-2.90 * * \\
(-1.95)\end{array}$ & $\begin{array}{c}-9.33 * * * \\
(-3.17)\end{array}$ \\
\hline Temporary Migrants & $\begin{array}{c}3385.73 * * * \\
(5.75)\end{array}$ & $\begin{array}{c}1854.87 * * * \\
(2.88)\end{array}$ \\
\hline Constant & $\begin{array}{c}3369.50 \\
(1.77)\end{array}$ & $\begin{array}{c}-3899.37 \\
(-1.74)\end{array}$ \\
\hline Observations & 46 & 72 \\
\hline R-squared & 0.89 & 0.79 \\
\hline
\end{tabular}

${ }^{\dagger}$ Dependent Variable: Monthly remittances sent by migrants. All amounts are expressed in Taka (Bangladesh Currency). Rate of currency conversion used: US $\$ 1=$ Taka78

Note: $* * * \mathrm{p}<0.01 ; * * \mathrm{p}<0.05 ;{ }^{*} \mathrm{p}<0.1$ 


\section{B.4 Interview Questionnaire}

\begin{tabular}{|l|l|}
\hline & Village Name: A or B \\
\hline 1. & Sex? \\
\hline 2. & Age? \\
\hline 3. & How many years of formal schooling did you have? \\
\hline 4. & Are you a temporary migrant or have you permanently migrated to India? \\
\hline 5. & $\begin{array}{l}\text { Are there other migrants from your household? If yes, how many? What is their } \\
\text { relationship with you? }\end{array}$ \\
\hline 6. & $\begin{array}{l}\text { Marital status? If married, does your spouse (and/or children) live with you in } \\
\text { India? }\end{array}$ \\
\hline 7. & If married, what is the age of your spouse? \\
\hline 8. & If a parent, how many children? Their ages? \\
\hline 9. & What is your profession in India? \\
\hline 10. & What was your profession in your village in Bangladesh? \\
\hline 11. & Where in India do you live and work? \\
\hline 12. & How much is your approximate monthly income?* \\
\hline 13. & $\begin{array}{l}\text { What is the household income (net of remittances) of your left-behind } \\
\text { households? }\end{array}$ \\
\hline 14. & Do you remit? If yes, what is the frequency of remitting? \\
\hline 15. & Whom do you send remittances to in your household? \\
\hline 16. & $\begin{array}{l}\text { If married, do you send remittances to both your own household as well as your } \\
\text { spouse's paternal/maternal home? }\end{array}$ \\
\hline 17. & Who is the main decision-maker in your left-behind household? \\
\hline 18. & $\begin{array}{l}\text { Generally, if everything remains the same, do you remit the same amount each } \\
\text { time? How much do you remit each time? }\end{array}$ \\
\hline 19. & $\begin{array}{l}\text { In the last one year, how many natural disasters affected your household (in the } \\
\text { village)? } \\
\text { Enter the dates for each disaster here: }\end{array}$ \\
\hline 20. & $\begin{array}{l}\text { Do you remit more to help mitigate the negative financial impact from the } \\
\text { disasters? If so, do you remit more money right away? What is the lag? } \\
\text { How much more on top of the usual amount do you remit? }\end{array}$ \\
\hline 21. & $\begin{array}{l}\text { Do you return home following disasters? If so, do you bring money with you } \\
\text { back home? }\end{array}$ \\
\hline 22. & Have you acted as a facilitator to help others from your village migrate? \\
\hline 23. & Do you participate in the activities organized by the local migrant organization? \\
\hline 24. & $\begin{array}{l}\text { Do you have friends in the community (village in Bangladesh)? Are they also } \\
\text { fellow migrants? }\end{array}$ \\
\hline &
\end{tabular}

Note: This was the main interview questionnaire. However, for most of the migrants, during in-depth interviews, further unscripted discussions took place from which the research greatly benefited.

* Not all migrants responded to this question 


\section{References}

Bäckman, S. \& Sumelius, J. (2009). Identifying the Driving Forces Behind Price Fluctuations and Potential Food Crisis. Retrieved from http://www.helsinki.fi/taloustiede/Abs/DP35.pdf

Bangladesh Bureau of Statistics. (2010). Statistical Yearbook [Data file]. Retrieved from http://203.112.218.65/PageWebMenuContent.aspx?MenuKey=230.

Bangladesh Bureau of Statistics (2017). Quarterly Labour Force Survey Bangladesh: 2015-2016. Retrieved from http://bbs.portal.gov.bd/sites/default/files/files/bbs.portal.gov.bd/page/96220c5a_ 5763_4628_9494_950862accd8c/QLFS_2015.pdf

Becker, G.S. (1974). A theory of social interactions. Journal of Political Economy, 82(6), 1063-1093. Retrieved from http://www.jstor.org/stable/1830662

Benson, C. \& Clay, E. (2004). Understanding the Economic and Financial Impacts of Natural Disasters. Disaster Risk Management Series No.4, The World Bank. Retrieved from http://hdl.handle.net/10986/15025

Chant, S. \& Radcliffe, S. A. (1992). Migration and Development: The Importance of Gender. In S. Chant (Ed.), Gender and Migration in Developing Countries (1-30). New York: Belhaven Press

Clarke, G. \& Wallsten, S. (2004). Do Remittances Protect Households in Developing Countries Against Shocks? Evidence from a Natural Disaster in Jamaica. Washington, DC: Mimeo

Collier, W., Piracha, M., \& Randazzo, T. (2011). Remittances and Return Migration. Institute for the Study of Labor Discussion Paper(6091). Retrieved from http://ftp.iza.org/dp6091.pdf. 
Collinson, M., Tollman, S., Kahn, K., \& Clark, S. (2003). Highly Prevalent Circular Migration: Households, Mobility and Economic Status in Rural South Africa. Retrieved from https://www.researchgate.net/publication/253094799_Highly_prevalent_circular_ migration_Households_mobility_and_economic_status_in_rural_South_Africa

Cox, D. (1987). Motives for private income transfers. Journal of Political Economy, 95(3), 508-546. Retrieved from https://doi.org/10.1086/261470

Cox, D., Eser, Z., \& Jimenez, E. (1998). Motives for private transfers over the life cycle: An analytical framework and evidence from Peru. Journal of Development Economics, 55(1), 57-81. Retrieved from https://doi.org/10.1016/S03043878(97)00056-4

Curran, S.R. \& Saguy, A. C. (2001). Migration and Cultural Change: A Role for Gender and Social Networks. Journal of International Women's Studies, 2(3), 54-77. Retrieved from http://vc.bridgew.edu/cgi/viewcontent.cgi?article=1619\&context=jiws Dasgupta, S., Huq, M., Khan, Z.H., Ahmed, M.M.Z., Mukherjee, N., Khan, M.F., \& Pandey, K. (2011). Vulnerability of Bangladesh to Cyclones in a Changing Climate. Policy Research Working Paper 5280, The World Bank. Retrieved from https://doi.org/10.1596/1813-9450-5280

Debnath, P. \& Selim, N. (2009) Impact of Short-term Male Migration on Their Wives Left Behind: A Case Study of Bangladesh. In Gender and Labour Migration in Asia, International Organization for Migration (Bangladesh). Retrieved from http://publications.iom.int/system/files/pdf/gender_and_labour_migration_asia. pdf 
Durand, J., Kandel, W., Parrado, E.A., \& Massey, D.S. (1996). International migration and Development in Mexican Communities. Demography, 33(2), 249-264. Retrieved from http://www.jstor.org/stable/2061875

Dustmann, C. \& Mestres, J. (2010). Remittances and Temporary Migration. Journal of Development Economics, 92(1), 62-70. Retrieved from http://www.creammigration.org/publ_uploads/CDP_09_09.pdf

Gedeshi, I. (2002). Role of Remittances from Albanian Emigrants and Their Influence in the Country's Economy. Eastern European Economics, 40(5), 49-72. Retrieved from http://www.jstor.org/stable/4380312

Ghosh, B. (2006). Migrants' Remittances and Development: Myths, Rhetoric and Realities. Retrieved from http://publications.iom.int/system/files/pdf/migrants_remittances.pdf

Gubert, F. (2002). Do migrants insure those who stay behind? Evidence from the Kayes Area (Western Mali). Oxford Development Studies, 30(2), 267-287. http://dx.doi.org/10.1080/1360081022000012699

Hicks, D. (1993). An Evaluation of the Zimbabwe Drought Relief Programme 1992/1993: The Roles of Household Level Response and Decentralized Decision Making. Harare: World Food Programme

Hugo, G. (1996). Environmental Concerns and International Migration. The international Migration Review, 30(1), 105-131. doi: 10.2307/2547462

Internal Displacement Monitoring Centre [IDMC]. (2013). Global Estimates 2012: People Displaced by Disasters. Retrieved from http://www.internaldisplacement.org/assets/publications/2013/2012-global-estimates-corporateen.pdf 
International Organization for Migration [IOM]. (2009). Migration, Environment and Climate Change: Assessing the Evidence. Retrieved from http://publications.iom.int/system/files/pdf/migration_and_environment.pdf International Organization for Migration [IOM]. (2010). Assessing the Evidence: Environment, Climate Change and Migration in Bangladesh. Retrieved from http://publications.iom.int/system/files/pdf/environment_climate_change_banglad esh.pdf

Kabeer, N. (1994). Reversed Realities: Gender Hierarchies in Development Thought. London: Verso.

Katz, E. \& Stark, O. (1986). Labor Migration and Risk Aversion in Less Developed Countries. Journal of Labor Economics, 4(1), 134-149. Retrieved from http://www.jstor.org/stable/2534880

Lucas, R., \& Stark, O. (1985). Motivations to remit: evidence from Botswana. Journal of Political Economy, 93(5), 901-918. Retrieved from http://www.jstor.org/stable/1833062

Massey, D., Arango, J., Hugo, G., Kouaouci, A., Pellegrino, A. \& Taylow, J.E. (1993). Theories of International Migration: A Review and Appraisal. Population and Development Review, 19(3), 431-466. doi: 10.2307/2938462

Massey, D., \& Parrado, E. (1994). Migradollars: the remittances and savings of Mexican migrants to the USA. Population Research and Policy Review, 13(1), 3-30. Retrieved from http://www.jstor.org/stable/40229687

McLeman, R. \& Smit, B. (2006). Migration as an Adaptation to Climate Change. Climate Change, 76(1-2), 31-53. doi: 10.1007/s10584-005-9000-7 
Merkle, L., \& Zimmermann,K. (1992). Savings, remittances and return migration.

Economic Letters, 38(1), 77-81. Retrieved from https://doi.org/10.1016/01651765(92)90165-U

Mohapatra, S., Joseph, G., \& Ratha, D. (2012). Remittances and Natural Disasters: Expost Response and Contribution to Ex-ante Preparedness. Environment, Development and Sustainability, 14(3), 365-387. doi: 10.1007/s10668-011-930-8

Piper, N. (2005). Gender and migration. Retrieved from http://incedes.org.gt/Master/pipersesentacuatro.pdf

Ramamurthy, B. (2003). International Labour Migrants: Unsung Heroes of Globalization. Retrieved from http://www.sida.se/contentassets/82f259c90c8547dcb3690b44bcb6c95e/internatio nal-labour-migrants-unsung-heroes-of-globalisation_1617.pdf

Ratha, D. \& Shaw, W. (2007). South-South Migration and Remittances. Retrieved from http://siteresources.worldbank.org/INTPROSPECTS/Resources/3349341110315015165/SouthSouthMigrationandRemittances.pdf

Rodriguez, E. (1996). International migrants' remittances in the Philippines. The Canadian Journal of Economics, 29(4). S427-S432. doi: 10.2307/136081

Secondi, G. (1997). Private Monetary Transfers in Rural China: Are Families Altruistic? Journal of Development Studies 33(4), 487-511. doi:

$10.1080 / 00220389708422478$

Smuggling. (2016). In International Organization for Migration [IOM] Key Migration Terms. Retrieved March 30, 2016 from https://www.iom.int/key-migration-terms. 
Sørensen, N. (2005). Migrant Remittances, Development and Gender. Retrieved from https://www.diis.dk/files/media/documents/publications/nns_migrant_remittances .pdf

Stark, O. \& Bloom, D. (1985). The New Economics of Labor Migration. The American Economic Review, 75(2), 173-178. Retrieved from http://www.jstor.org/stable/1805591

Suleri, A., \& Savage, K. (2006). Remittances in Crisis: A Case Study of Pakistan. Retrieved from https://www.odi.org/sites/odi.org.uk/files/odi-assets/publicationsopinion-files/385.pdf

Tacoli, C. (1999). International Migration and the Restructuring of Gender Asymmetries: Continuity and Change Among Filipino Labor Migrants in Rome. International Migration Review, 33(3), 658-82. doi: 10.2307/2547530

Trafficking in Persons. (2016). In International Organization for Migration [IOM] Key Migration Terms. Retrieved March 30, 2016 from https://www.iom.int/keymigration-terms

Unheim, P., \& Rowlands, D. (2012). Micro-level Determinants of Remittances from Recent Migrants to Canada. International Migration, 50(4), 124-139. doi: $10.1111 / \mathrm{j} .1468-2435.2011 .00718 . \mathrm{x}$

Weiss Fagen, P. (2006). Remittances in Crisis: A Haiti Case Study. Retrieved from https://www.odi.org/sites/odi.org.uk/files/odi-assets/publications-opinionfiles/412.pdf

Weiss Fagen, P. \& Bump, M.N. (2006). Remittances in Conflict and Crises: How Remittances Sustain Livelihoods in War, Crises, and Transitions to Peace. Security-Development Nexus Program Policy Paper, International Peace 
Academy. Retrieved from https://www.ipinst.org/wpcontent/uploads/publications/remittances_erpt.pdf

The World Bank. (2015). Migration and Development Brief 24. Retrieved from https://siteresources.worldbank.org/INTPROSPECTS/Resources/3349341288990760745/MigrationandDevelopmentBrief24.pdf

The World Bank. (2006). Global Economic Prospects 2006: Economic Implications of Remittances and Migration. Retrieved from http://pubdocs.worldbank.org/en/346121443469727614/Global-EconomicProspects-2006-Economic-implications-of-remittances-and-migration.pdf

Wu, T. (2006). The Role of Remittances in Crisis. An Aceh Research Study. Retrieved from https://www.odi.org/sites/odi.org.uk/files/odi-assets/publications-opinionfiles/408.pdf

Yang, D. (2007). Coping with Disaster: The Impact of Hurricanes on International Financial Flows, 1970-2002. National Bureau of Economic Research. doi: $10.3386 / \mathrm{w} 12794$ 


\section{Chapter 4: Impact of Natural Disasters on Aggregate Remittances Inflows: The Case of Pakistan}

\subsection{Introduction}

According to the International Emergency Disasters Database (EM-DAT), during the period 1996-2010, Pakistan experienced 94 natural disasters including earthquakes, monsoon floods, cyclones and drought. For the same period, remittances into Pakistan more than quadrupled to US\$9 billion (State Bank of Pakistan, 2016). Remittances have become an important source of development finance for many developing countries, including Pakistan, and they now surpass many other traditional flows such as the official development assistance (ODA) and foreign direct investment (FDI) (The World Bank Open Data, 2016). The figure below shows the magnitude of remittances compared to other external financial inflows into Pakistan for the study period 1996-2010 as a share of the gross domestic product (GDP). 
Figure 4.1 Various Development Finance Inflows to Pakistan (1996-2010)

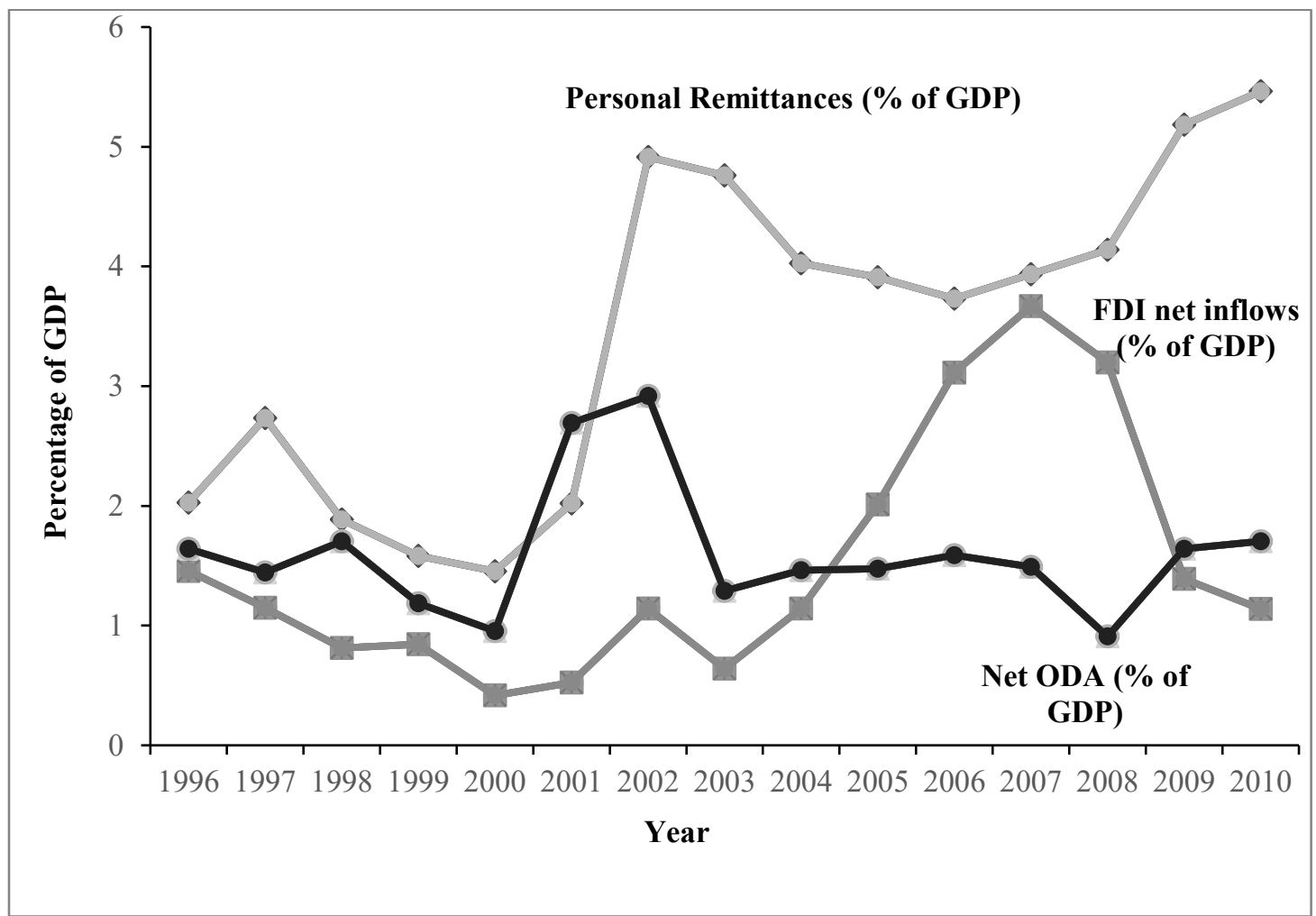

Source: The World Bank Open Data, 2016

Several country specific studies have found that remittances make people more resilient in the face of natural disasters (Suleri \& Savage, 2006; Wu, 2006). There is compelling evidence that migration as well as remittances reduce the level, depth and severity of poverty (Adams \& Page, 2005; Irfan, 2011, Jongawanich, 2007; The World Bank, 2006). Some have argued that in the aftermath of crisis it may be easier to reestablish remittance flows than other types of income and livelihoods, allowing remittance recipients to begin the recovery process more quickly (Suleri \& Savage, 2006).

Although there are a few recent studies on Pakistan that have focused on understanding the linkages between remittances and poverty (Kalim \& Shahbaz, 2008) and remittances and terrorism (Mughal \& Anwar, 2014), there are no country level studies that analyze the linkages between remittance inflows and natural disasters. The closest attempt to understanding the relationship between remittances and natural disasters was undertaken 
by Suleri and Savage (2006), when they specifically examined the role of international remittances following the 2005 earthquake that hit northern Pakistan, killing more than 73,000 people and affecting more than three million.

This chapter addresses this gap in the literature by examining the impact of natural disasters on the aggregate inflow of international remittances into Pakistan. More specifically, using monthly remittance and natural disaster data for the period 1996-2010, this chapter examines the responsiveness of remittances sent to Pakistan following natural disasters in the country. In doing so, this chapter also estimates the role of other important country specific determinants such as terrorism-related events and major religious events on remitting patterns. The rationale for including terrorism-related fatalities stems from the discussions presented in Mughal and Anwar (2014). The addition of major religious events is a novel contribution motivated by familiarity with remittances to the region and the importance of religion in maintaining transnational family ties. These inclusions are necessary to try and specify the best estimating equation possible.

This remainder of this chapter is structured as follows. Section 4.2 provides an overview of the relevant existing literature on remittances in Pakistan. Section 4.3 describes the methodology and provides background information about the sample and the estimating procedure. Section 4.4 discusses the findings of the chapter, while Section 4.5 presents sensitivity analysis of the results. Section 4.6 concludes the chapter.

\subsection{Literature Review}

\subsubsection{Migration Theories}

Over the years migration scholars have developed a series of theoretical models to explain the forces behind international migration. Although each of the various theories eventually attempt to explain the same thing - why people move - they often start from 
radically different concepts, hypotheses and frames of reference (Anghel \& Horvath, 2009; Porumbescu, 2015). Neoclassical economic theory emphasizes the role of wage differences between nation states and the costs associated with migration, and for the most part views migration as an individual's decision to maximize his or her income. This theory links labour mobility to the structural requirements of the modern industrial societies. On the other hand, the New Economics of Labour Migration (NELM) focuses on the constraints in various markets, not just the labour market. NELM theory considers migration as a family decision aimed at minimizing the risks and overcoming temporary financial constraints faced by the household (Badie \& Withol, 1993; Porumbescu, 2015). The dual work market theory and the global systems theory ignore, in general, "the processes of adopting the decision to migrate on a micro level, focusing, in return, on the forces that act on a larger scale" (Porumbescu, 2015, p. 56). NELM theory, dual market theory as well as global systems theory view migration "as a natural consequence of the economic globalization and vanish [sic] of the national borders under the pressure of the international markets" (Porumbescu, 2015, p. 56).

The main research question of this chapter - how do migrants' remitting patterns react in the aftermath of natural disasters affecting their home country - is rooted in the theoretical premise put forward by the NELM theorists. According to NELM scholars, the decision to emigrate is taken by the migrant in consultation with their households. The members of the households collaborate to maximize elements of their joint welfare by enhancing earnings and minimizing risks. In countries such as Pakistan, where many households are susceptible to natural disasters as well as disasters that are induced by human behaviour (for instance, terrorism), households engage in migration as a riskmitigation strategy to diversify household income sources (Carling, 2008; Katz \& 
Stark, 1986; Mughal \& Anwar, 2014; Stark \& Bloom, 1985). Migrants emigrating to send remittances home is a rational choice - a hedge against domestic economic downturns (Cerón Monroy, 2004).

Among the early scholars, Johnson and Whitelaw (1974) identified altruism to be one of the key factors motivating migrant remittances. Since then, other equally compelling factors shaping migrants' decisions to remit have been suggested. For instance, Lucas and Stark (1985) argue that migrants can also remit due to purely self-interested reasons, including remitting to family members to ensure a future inheritance or to oversee their local investments and assets while they are away. Lucas and Stark (1985) also discussed another theory called "tempered altruism" or "enlightened self-interest". This theory is based on an understanding that there is a self-enforcing cooperative contractual arrangement between migrants and their families (Glytsos, 2002). This contractual relationship is based on families investing in the human capital acquisition of some family members who then migrate and repay the investments via remittances (Glytsos, 1988, Lucas \& Stark, 1985). Further, in the absence of perfect insurance and capital markets, this process serves as a mutually beneficial agreement between the migrants and their families - migrants' remittances provide insurance and compensate for negative economic shocks affecting their households in the home country (Agarwal \& Horowitz, 2002; Gubert, 2002; Lucas \& Stark, 1985).

Since the 2000s, scholars have added new lenses to understand the motives behind remittances. Theories of transnationalism highlight the power of forces of globalization and its accompanying technological advancements which makes it possible for migrants to remain engaged and participate in the affairs of their family in their country of origin 
(Mamattah, 2006; Vertovec, 2001). Remittances can serve as a mechanism for migrants to maintain and strengthen these family ties.

\subsubsection{Pakistan Remittance Literature}

During the last three decades, macro-level studies have investigated the effects of international labour migration and remittances on Pakistan's domestic economic growth, employment generation and poverty reduction (Amjad \& Arif, 2014). In a 2005 study, Zafar and Sattar examined the contribution of remittances to economic growth in Pakistan. They found that during 1972-2005, remittances made an important contribution to real GDP growth in Pakistan. A more recent study by Kalim and Shahbaz (2008) investigated the role of remittances in reducing poverty in Pakistan during the period 1973-2006, and concluded that they play a key role in reducing poverty. Another similar study by Qayyum, Javid and Arif (2008) found that remittances affect economic growth positively and significantly and have a statistically significant impact on poverty reduction. Scholars have also tried to estimate the multiplier effect of remittances on Pakistan's economy. Jamal (2004) found that for national income, the remittance multiplier is estimated as 3.07 , which indicates that an increase of one million (Pakistani rupees ${ }^{32}$ ) in international remittances would result in a three-fold increase in national income or Gross National Product.

Macro level studies on Pakistan also focused on understanding the robustness of remittance inflows into Pakistan. A study by Kock and Sun (2011) found that remittances to Pakistan are more resilient than those to other countries in the South Asia region. Among other factors they attribute this to the economic boom in the Gulf Cooperation Council (GCC) countries which is the destination for a considerable number of Pakistani migrants.

\footnotetext{
${ }^{32}$ As of June 1, 2017, US\$1= 100 Pakistani Rupees
} 
Several micro-level studies have utilized household survey data and focused on specific regions within Pakistan to understand the role of remittances. For instance, a study on the Peshawar District found that migrant households spent approximately 40 per cent of their remittances on food consumption and 38 per cent for purchasing real estate and agriculture machinery (Amjad \& Arif, 2014). The remainder is used to purchase consumer durables, pay for weddings, and for health and education. Similarly, a study conducted by Gioli, Khan, and Scheffran (2013) in conflict-affected villages within the Peshawar District found that remittances played a critical role in ensuring the survival of these households during times of conflict. Out of 602 households in the survey sample, almost 74 per cent reported that they have avoided starvation due to remittances, as all normal activity came to a standstill due to prolonged curfews and on-going violence in their area. Additionally, 23 per cent of the respondents stated that in the aftermath of the conflict, remittances were the major source of income to help them rebuild their livelihoods.

\subsubsection{Remittances and Natural Disasters in Pakistan}

Despite the growing interest in understanding various perspectives on remittances, there is a dearth of macro-level studies that investigate the relationship between remittance inflows and natural disasters. The need to mitigate the harmful effects of this sort of adverse shock exactly fits the sort of risk management motivation underpinning the NELM theory. Following the October 2005 devastating earthquake in the North-West Frontier Province (NWFP) and Kashmir, there have been attempts to understand the role of remittances in rebuilding the local economies; however, those attempts have been limited to the 2005 event and the location of the disaster occurrence. A 2006 case study by Suleri and Savage on the 2005 earthquake found that households whose livelihoods included remittances appeared less vulnerable to the adverse effects of the earthquake. Remittances enabled 
households "to repair and reconstruct their homes much more easily than non-remittance recipient households" (Suleri \& Savage, 2006, p.1). In the aftermath of the earthquake, remittance recipients were able to use their remittances to obtain necessary private health care. In contrast, households who did not receive remittances were forced to rely on public healthcare, and in some cases had to sell assets to pay for further treatment (Suleri \& Savage, 2006). For these rural families, remittances allowed them to pay for the transport costs to reach various distribution points for the relief aid provided by the government and non-governmental organizations.

Other micro-level Pakistani studies on remittances have commented on the fact that remittances help to alleviate adverse shocks (Kock \& Sun, 2011), however, these studies did not engage in rigorous analysis of the data on natural disasters and remittances to examine the linkages between the two. This chapter contributes to the burgeoning literature on environmental events and their linkages to remittances by examining macro level data of all disasters that affected Pakistan during the period 1996-2010.

\subsubsection{Remittances and Terrorist Events}

With the rise of terrorist events across the globe, there has also been a growing interest in understanding the linkages between remittances and terrorist events. One of the first macro-level study that investigates the relationship between remittances and terrorism was undertaken by Mascarenhas and Sandler (2013). In this paper, the authors analyze the effects of remittances on terrorism using a global sample of 142 developing and developed countries for 1980-2010. One of the main findings of this paper provides support for the argument that remittances may be finding their way to terrorists, who can employ these resources to fund various types of terrorist activities. 
In relation to studies on Pakistan, Ullah, Rahman, Jebran, and Zeb (2015) examine the relationship between terrorism and remittances in Pakistan for the period 1995-2013. Their findings indicate that people emigrated as a response to terrorism. According to their findings, when terrorism increases, people migrate to foreign countries, which ultimately had a positive effect on remittances inflows into Pakistan. Another 2014 study on Pakistan by Mughal and Anwar examined the short-run behaviour of migrant remittances in the face of terrorism for the period 2003-2011. The authors conclude that for the period studied "remittances rise to help the migrant households cope with the financial repercussions of terrorism" (Mughal \& Anwar, 2014, p. 14).

Although the predominant focus of this chapter is to investigate the relationship between remittance inflows to Pakistan in the aftermath of natural disasters (1996-2010), this chapter includes terrorist fatalities that occurred in Pakistan during the same period to understand the explanatory power of these adverse events on remittance patterns.

\subsubsection{Remittances and Major Religious Events in Pakistan}

Along with disaster-related variables and terrorism-related variables, two additional independent variables were included in the estimation model to investigate whether remittances changed predictably with major religious events in Pakistan, a country that has over 95 per cent Muslim population (World Atlas, n.d.). These two religious events are: 1) Two occurrences of Eid festivities each year. The first of the two Eid festivals is called Eid al-Fitr, which celebrates the end of Ramadan (the Islamic holy month of fasting). The second is called Eid al-Adha. The majority of Muslims observe Eid-al-Adha by sacrificing animals such as cows and goats. 2) Hajj - annual Islamic pilgrimage to Mecca (the holy city for Muslims) and a mandatory religious duty for Muslims that needs 
to be carried out at least once in their lifetime by those who are physically and financially capable of undertaking the journey (History of Hajj, 2017).

It is expected that during Eid festivities migrants' might respond by sending more remittances to their households to help with the costs associated with celebrations and buying presents for their family members and friends that have remained in Pakistan. A 2016 study on Pakistan found that during Eid holidays Pakistani migrants tend to remit more to their families (Qureshi, 2016). In addition, it is expected that migrants might increase their remittances during the Hajj period to assist their parents and family members to cover the costs associated with participating in the pilgrimage (Asian Development Bank, 2012).

\subsection{Methodology: Data Sources, Sample Construction and Estimating Procedure}

The empirical analysis in this chapter is based on data from three data sources - the

State Bank of Pakistan's Workers' Remittance Database, disaster data from the International Emergency Disasters Database (EM-DAT) and terrorism data from the Global Terrorism Database (GTD). These data sets are described in detail below.

\subsubsection{State Bank of Pakistan's Workers' Remittance Database}

This database houses monthly international remittance inflows into Pakistan. A significant portion of international remittances into Pakistan comes from Pakistani migrants living in the Middle East (more than 60\%). Those who are living in the US and the UK also contribute a sizeable portion (almost 30\%) of remittance inflows. 
Figure 4.2 Remittances by Host Countries (1996-2010)

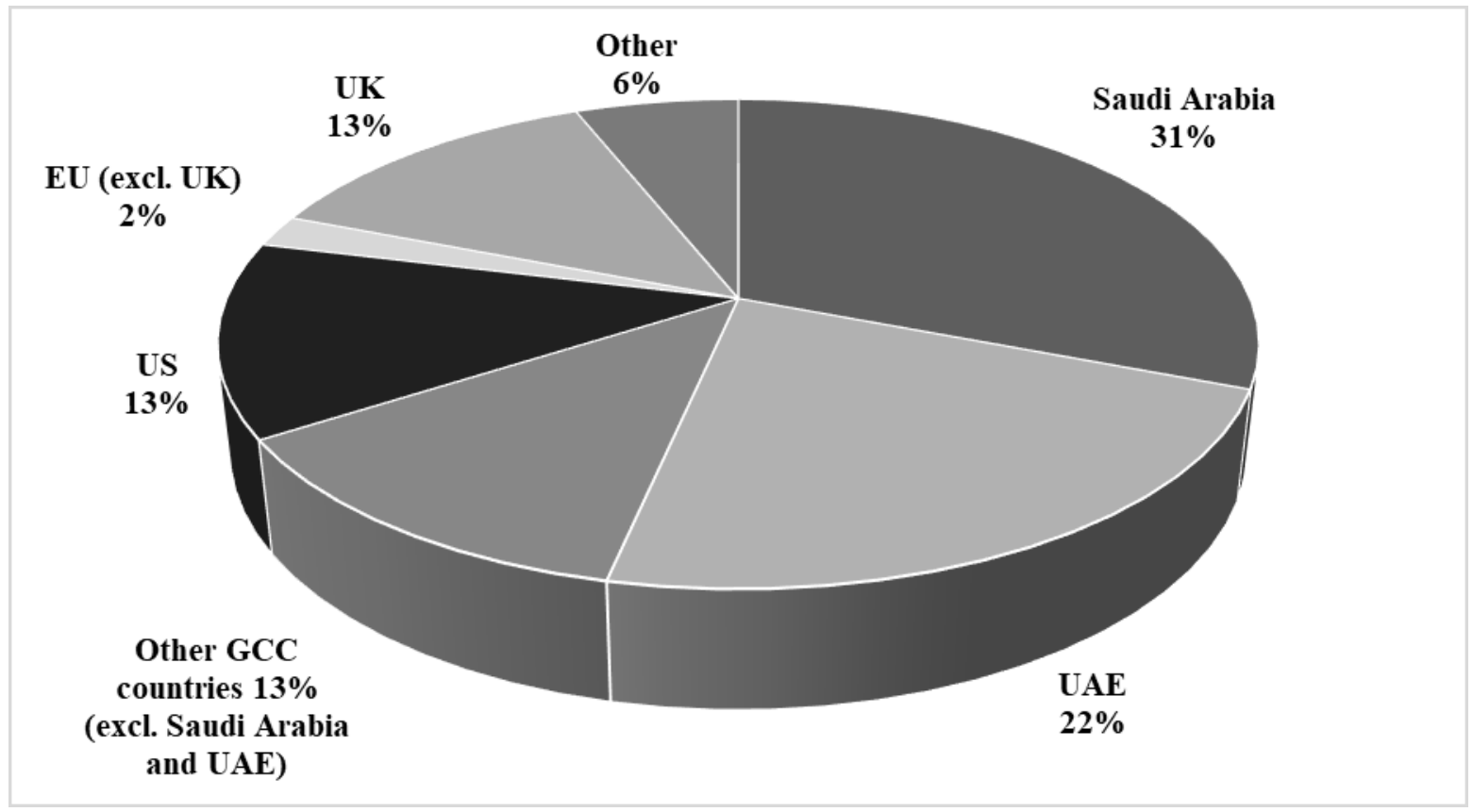

Source: State Bank of Pakistan, 2016

The GCC is a regional intergovernmental political and economic union consisting of all Arab states of the Persian Gulf, except for Iraq. Its member states are Bahrain, Kuwait, Oman, Qatar, Saudi Arabia, and the United Arab Emirates. The EU countries in this case include Belgium, Denmark, France, Germany, Greece, Ireland, Italy, Netherlands, Spain and Sweden.

Figure 4.3 below shows the total remittance inflows into Pakistan during the period 1996-2010. Figures 4.4-4.10 show remittance inflows into Pakistan from some of the major host countries and regions for the same period. 
Figure 4.3: Total Remittances Inflows to Pakistan

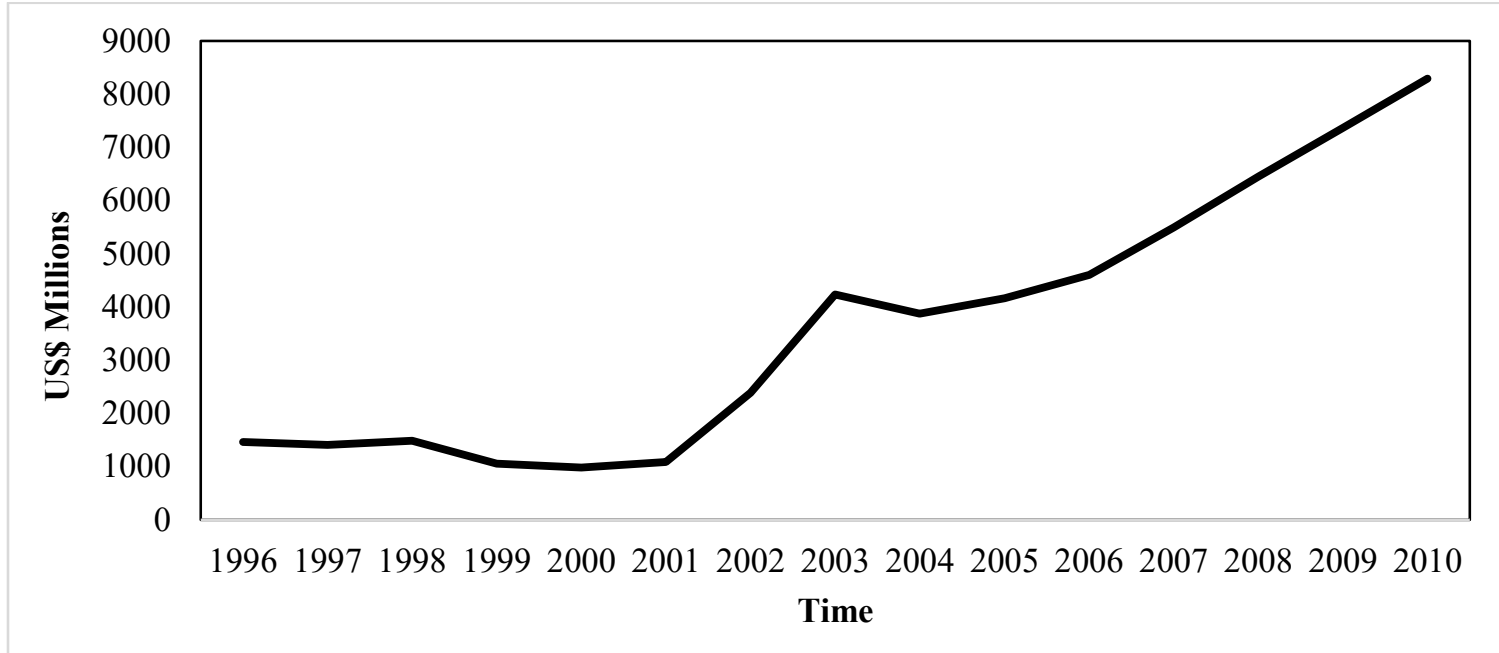

Figure 4.4: Remittances to Pakistan from Saudi Arabia

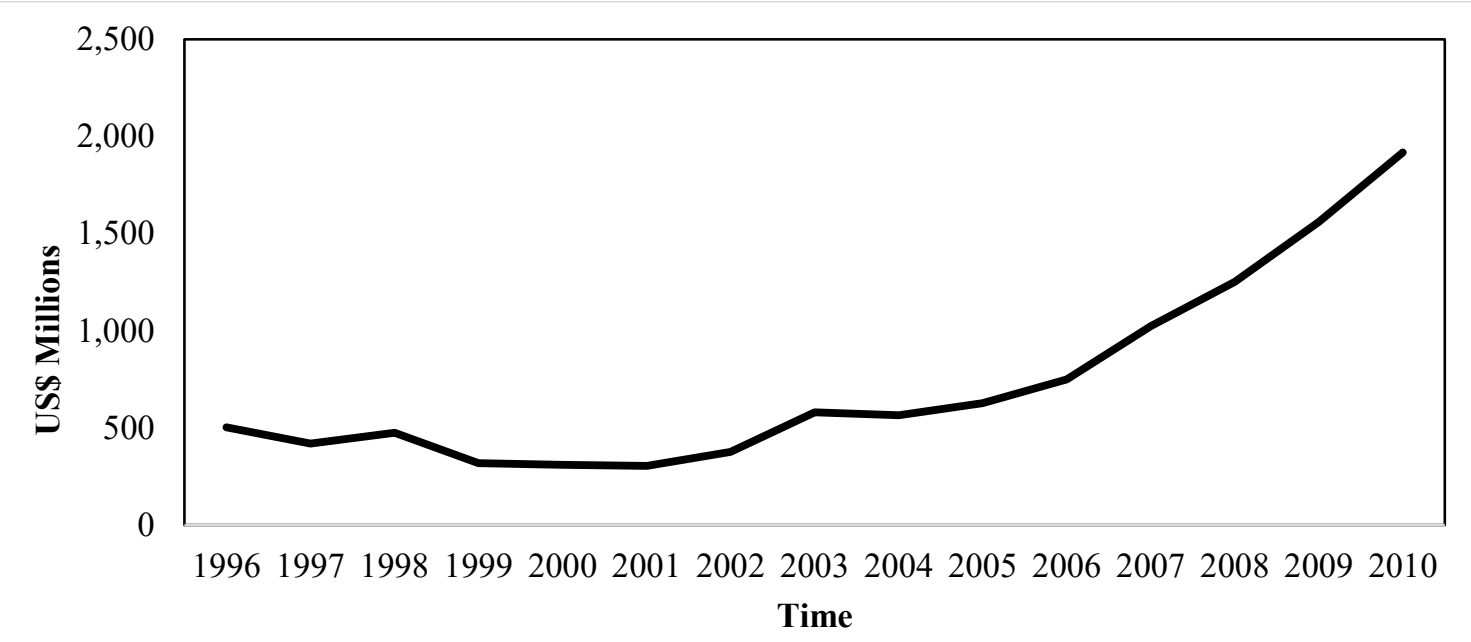


Figure 4.5: Remittances to Pakistan from Canada

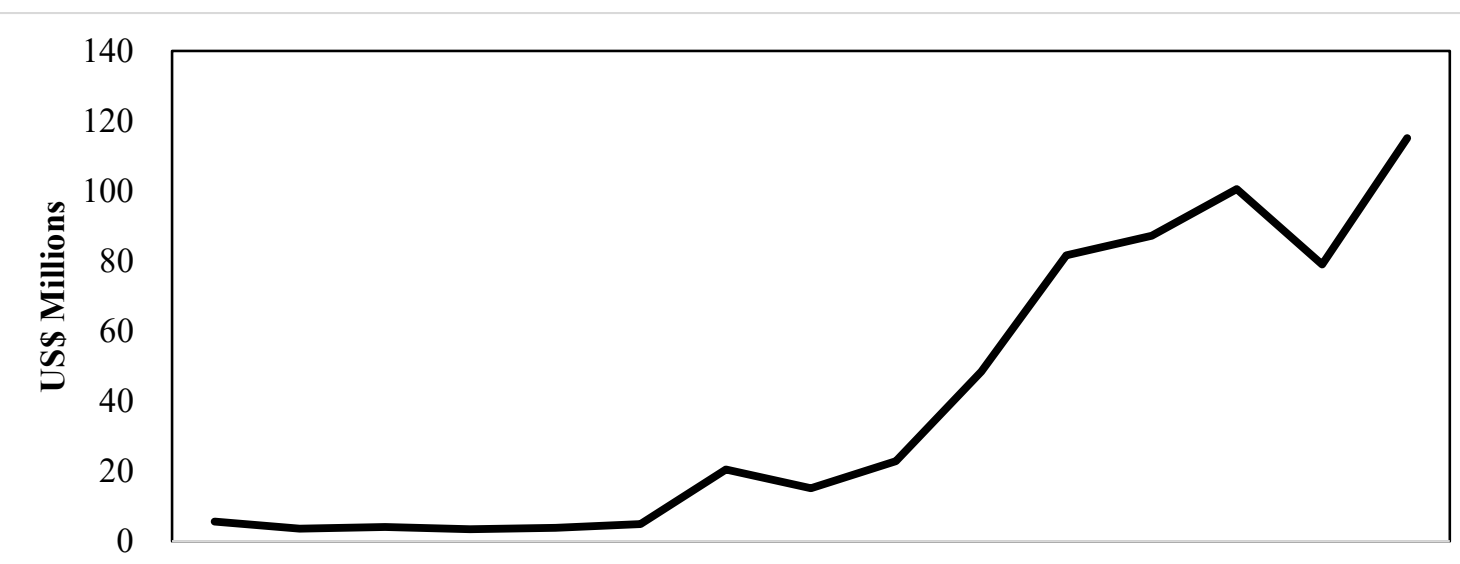

199619971998199920002001200220032004200520062007200820092010

Time

Figure 4.6: Remittances to Pakistan from US

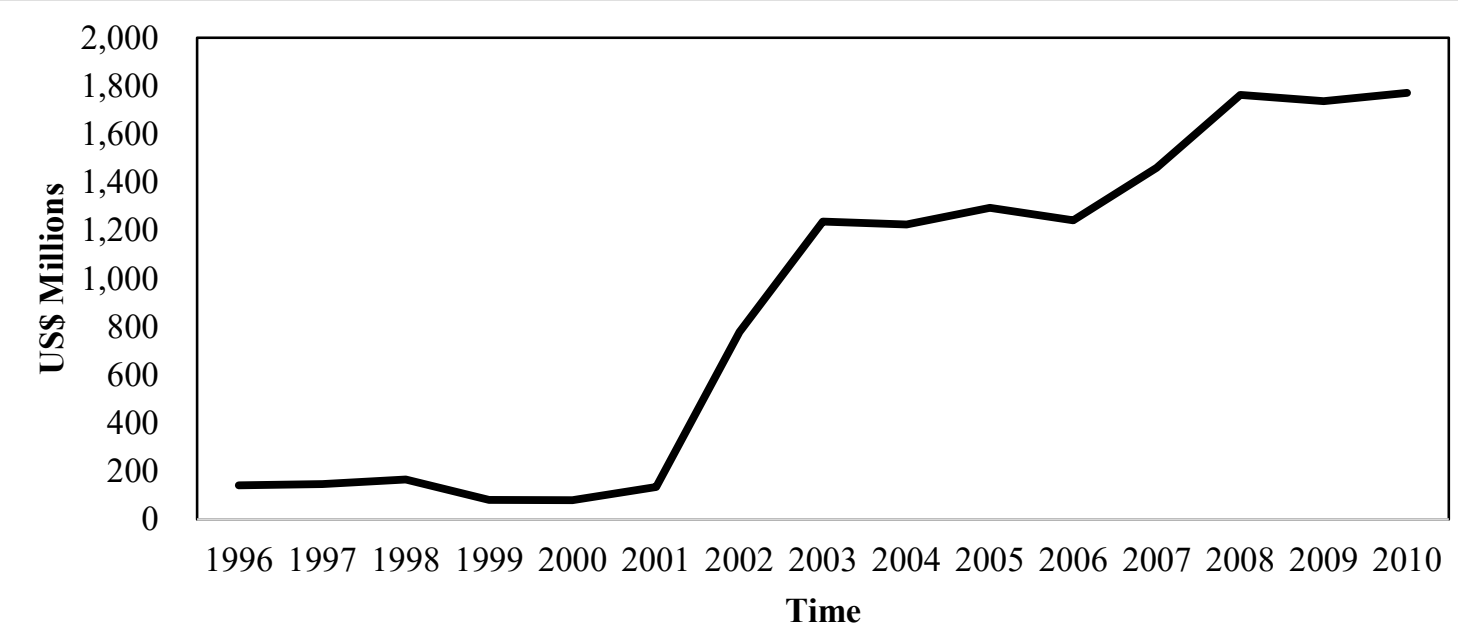


Figure 4.7: Remittances to Pakistan from the UK

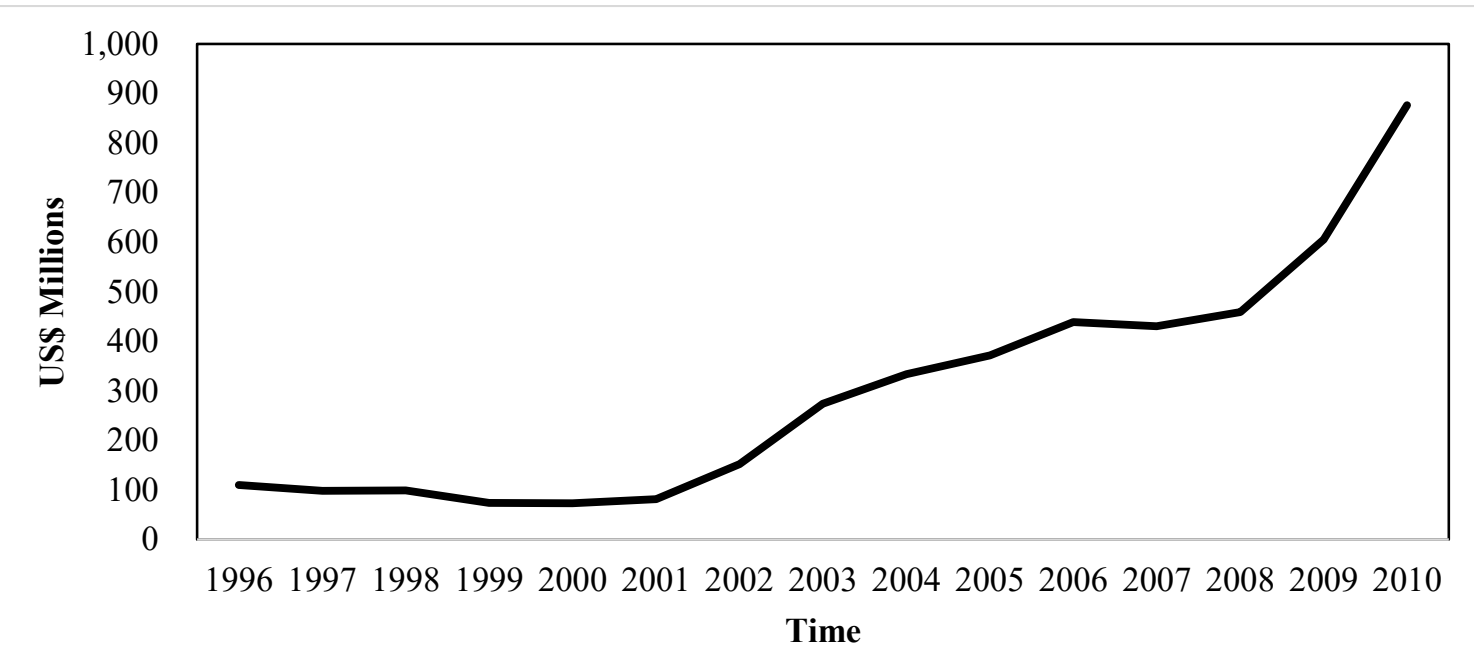

Figure 4.8: Remittances to Pakistan from EU (excl. UK)

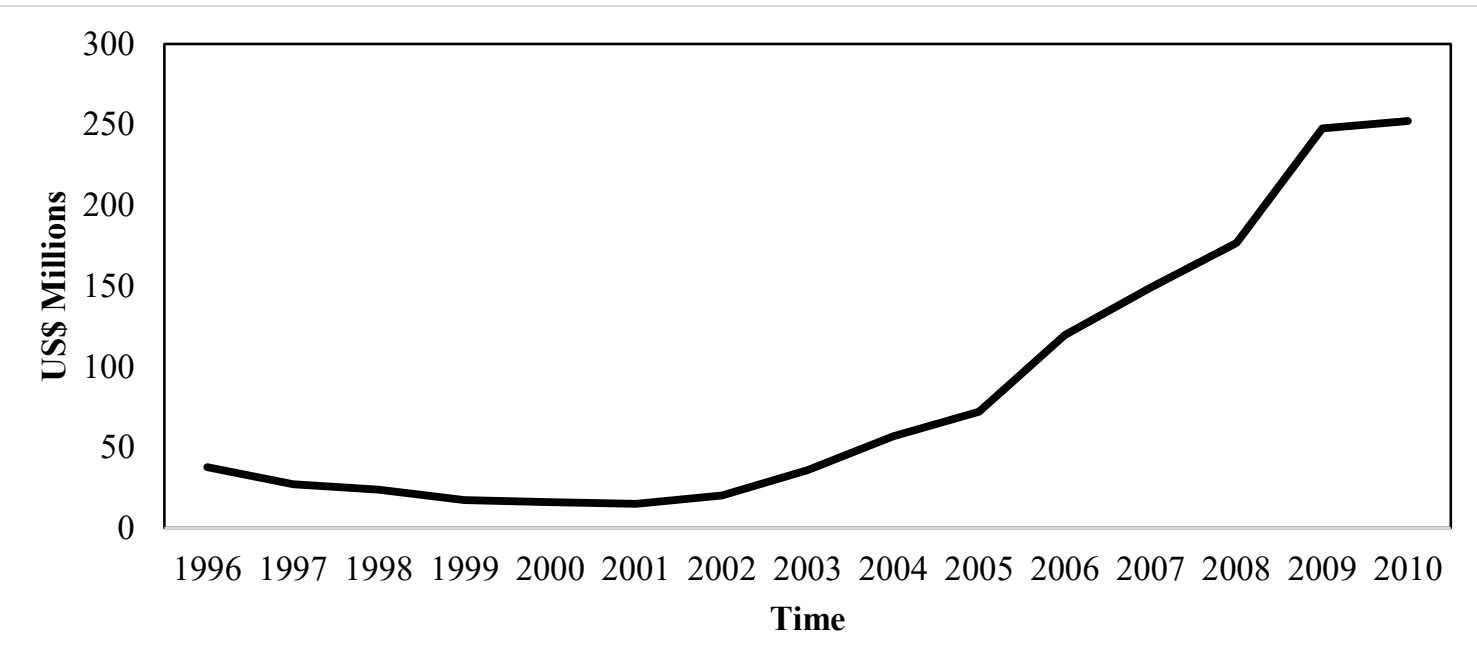


Figure 4.9: Remittances to Pakistan from UAE

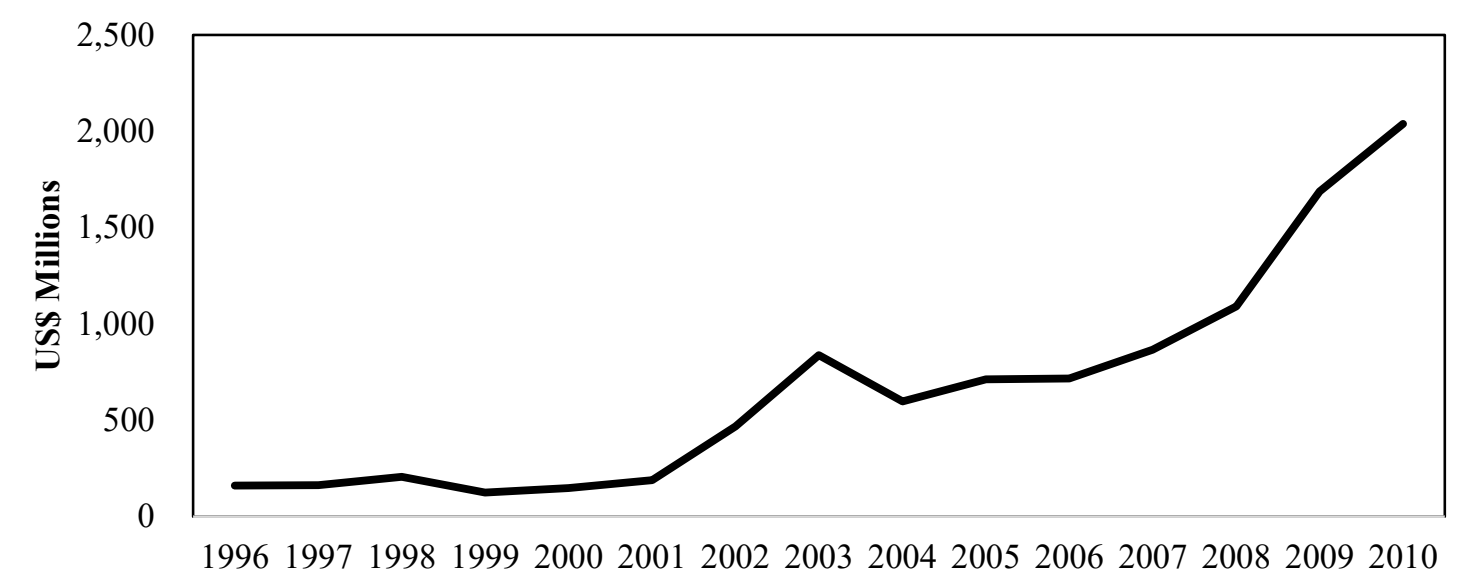

Time

Figure 4.10: Remittances to Pakistan from other GCC Countries (excl. Saudi Arabia and UAE)

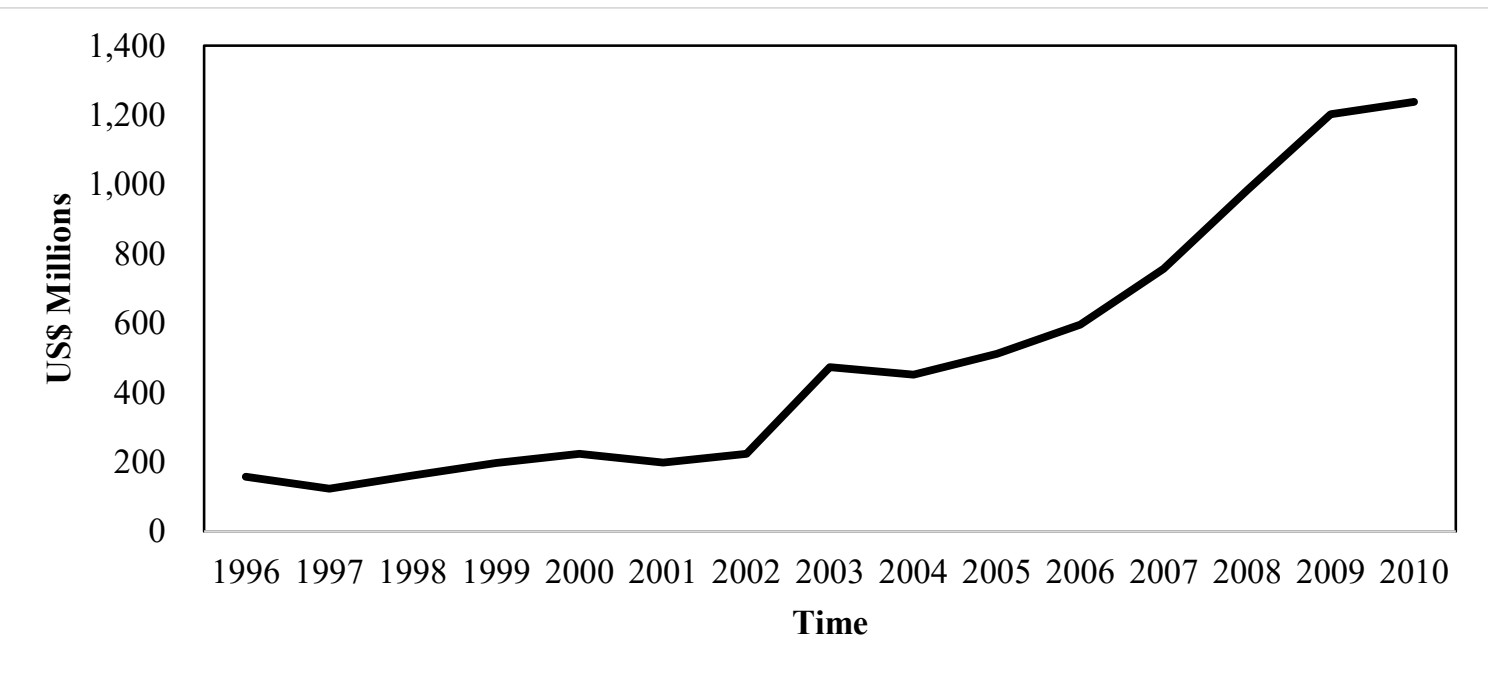

As can be seen in the above figures, remittances into Pakistan have been increasing steadily since 2001 . The extent to which this increase is purely due to a shift in the migrants' choice of remitting channels - moving from unofficial to official - is yet to be fully determined. It is important to recognize that this effect could be because of the increase in global anti-money laundering initiatives following the September 11, 2001 terrorist attacks in the US. As a result, the hypothesis of this chapter is investigated for two 
separate time periods: 1996-2010 and from 2002-2010 to ensure the robustness of the results. $^{33}$

\subsubsection{Disaster Data from the Center for Research on the Epidemiology of Diseases (CRED), International Emergency Disasters Database (EM-DAT)}

The natural disasters data used in this chapter are from CRED's International Emergency Disasters Database (EM-DAT). The EM-DAT contains essential data on the occurrence and effects of over 12,000 mass disasters in the world from 1900 to present. The database is compiled from various sources, including UN agencies, nongovernmental organizations, insurance companies, research institutes and press agencies.

CRED defines a disaster as a natural situation or event which overwhelms local capacity, necessitating a request for external assistance (Noy, 2008; EM-DAT Glossary of terms). EM-DAT groups disasters into several categories including hydrological disasters caused by the occurrence, movement, and distribution of surface and subsurface freshwater and saltwater (floods, landslides, wave action), climatological disasters caused by longlived, meso- to macro-scale atmospheric processes ranging from intra-seasonal to multidecadal climate variability (drought, wildfire, glacial lake outbursts, etc.), meteorological disasters caused by short-lived, micro- to meso-scale extreme weather and atmospheric conditions that last from minutes to days (extreme temperatures, storms, etc.) and geophysical disasters originating from solid earth (earthquakes, volcanic activity, etc.). Each of these disaster categories are not mutually exclusive and should be considered more as a typological classification.

\footnotetext{
${ }^{33}$ Checking for robustness here refers to checking the possibility that pre $9 / 11$ data and post 9/11 data may not be comparable due to changes in measurement and administrative rules.
} 
For a disaster to be entered into the EM-DAT database at least one of the following criteria needs to be fulfilled: (1) at least 10 people are reported killed; (2) 100 people are reported as affected; (3) declaration of a state of emergency; or (4) call for international assistance to help mitigate its impact (Noy, 2008). However, it is unlikely that all disasters will provoke a response by a country's diaspora. First, some of the disasters are quite small in terms of casualties and people affected, and might not attract significant response even from those who have emigrated from the locality in which the disaster took place. Large disasters, however, are more likely to induce remittances both because of the severity, but also because of the higher probability that migrants will be from the affected area or have family members in need.

In relation to the natural disaster variables, this chapter uses one of CRED's disaster-related variables (the number of people killed during the disaster) to measure the magnitude of the disaster. The other two variables are not included in the final estimations because complete data for these two variables are not available for all the disaster events during the two study periods.

According to the International Federation of Red Cross and Red Crescent Societies (2014), Pakistan has the highest average number of people physically exposed to floods on an annual basis in the South Asia region. These floods usually occur due to severe storm systems originating from the Bay of Bengal during the monsoon season, typically from July to September (International Federation of Red Cross and Red Crescent Societies, 2014).

According to the CRED database, during the period 1996-2010, Pakistan faced 94 natural disasters including earthquakes, monsoon floods, cyclones and drought. During this period, Pakistan witnessed five disasters that killed more than 5,000 people. Among these 
five disasters, three are reported as some of the most catastrophic disasters in Pakistan's history. These three major disasters include - floods in 1998, an earthquake in 2005 and floods in 2010. Among these three disasters, the 2005 earthquake and the 2010 flood were particularly catastrophic (International Federation of Red Cross and Red Crescent Societies, 2014).

The 2005 earthquake hit northern Pakistan killing over 73,000 people and affecting more than three million in the North-West Frontier Province (NWFP) and Kashmir (Suleri and Savage, 2006). The affected area covered some 30,000 square kilometers of mostly remote and mountainous terrain. An estimated 600,000 homes, 6,000 schools and 500 health facilities were destroyed, leaving millions of survivors to face not only the loss of their families, communities and livelihoods, but also the imminent arrival of the region's freezing winter weather without adequate shelter and the means to meet basic lifesustaining needs (Suleri \& Savage, 2006).

In 2010, Pakistan was hit by the most severe floods it has seen to date. The heavy monsoon rains which occurred in July 2010 created floods affecting over 20 million people and approximately 70 per cent of the country, more than that of the 2004 Indian Ocean Tsunami, the 2005 South Asia Earthquake and the 2010 Haiti Earthquake combined (International Federation of Red Cross and Red Crescent Societies, 2014). The scale of destruction was unprecedented: approximately one-fifth of Pakistan's total land area was underwater. The Asian Development Bank placed the total damage of these floods at more than US\$10 billion (International Federation of Red Cross and Red Crescent Societies, 2014). 


\subsubsection{Terrorism Data from the Global Terrorism Database (GTD)}

The Global Terrorism Database, maintained at the University of Maryland (US), catalogues data on terrorist events around the world from 1970 through 2016 (with annual updates planned for the future). The GTD's data is based on reports from a variety of open media sources. For the period 1970-1997, the GTD defined terrorism as "the threatened or actual use of illegal force and violence by a non-state actor to attain a political, economic, religious, or social goal through fear, coercion, or intimidation" (GTD, 2015). For the period 1997 onwards, this definition was further enhanced to include only intentional acts of violence or threats of violence by a non-state actor. In addition, two of the following three criteria also have to be met for inclusion in the GTD database for the period post 1997:

- The violent act was aimed at attaining a political, economic, religious, or social goal;

- The violent act included evidence of an intention to coerce, intimidate, or convey some other message to a larger audience (or audiences) other than the immediate victims; and

- The violent act was outside the precepts of International Humanitarian Law.

According to the GTD data, for the period 1996-2010, on average every month there were 44 terrorism-related fatalities in Pakistan. Figure 4.11 shows the number of terrorismrelated fatalities during this period. 


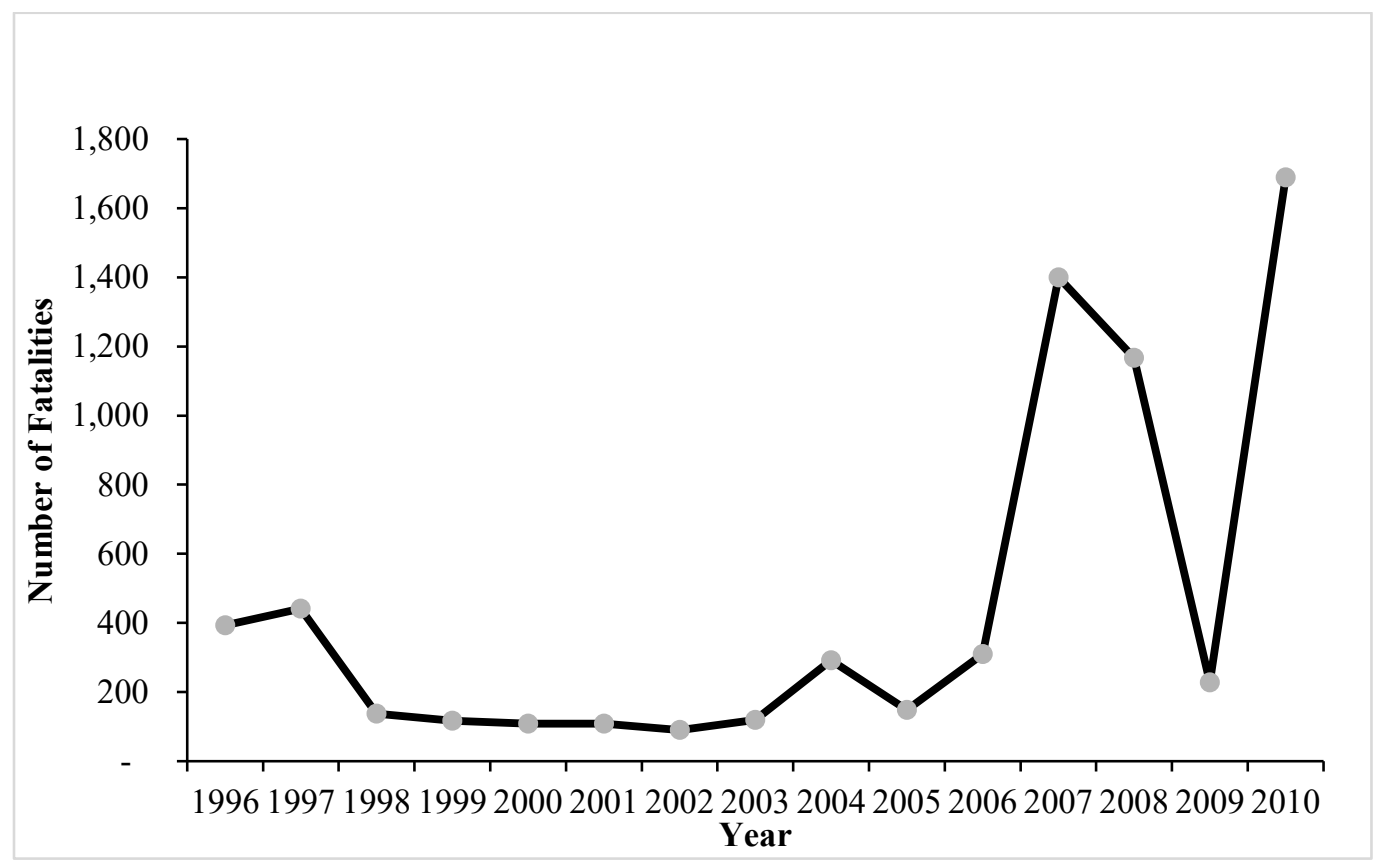

\subsubsection{Model Specification}

The model presented here tests whether Pakistani migrants' change their remittances in the aftermath of natural disasters affecting Pakistan. The dependent variable of interest is monthly total remittances to Pakistan as reported in the State Bank of Pakistan's dataset. In relation to the natural disaster variables, as discussed earlier, this chapter uses one of CRED's disaster-related variables (the number of people killed during the disaster) to measure the magnitude of the disaster.

The monthly remittance data are then examined to determine how they may change in the aftermath of a natural disaster. The expectation is that the relationship will be positive, indicating that migrants increase remittances to help offset at least some of the losses caused by the disaster. It is also possible, however, that disasters could repel remittances in the short-run because of the possible difficulty in locating family members and finding ways of getting money to them securely. For this reason, the statistical tests used here are two-tailed. 
Along with disaster-related variables and terrorism-related variables, two other independent variables - Eid and Hajj - were included in the estimation model. As discussed earlier, each year there are two Eid events - Eid al-Fitr and Eid-al-Adha -that are coded as one variable and included in the estimation equation. ${ }^{34}$

\subsection{Empirical Results and Discussions}

As discussed earlier, given that remittance inflows to Pakistan from all sources show an increase following September 2001, the same estimation is run on two-time periods: January 1996-December 2010 and from January 2002-December 2010 to ensure the robustness of the conclusions.

The first step in the empirical analysis was to test the data for non-stationarity, which could be a potential problem given the evidence in Figures 4.3-4.10 above. The Phillips-Perron test was used to check for the presence of a unit-root. According to the results of the Phillips-Perron test, the series is stationary with a trend, and so it is possible to proceed with a standard regression model without being concerned with any potentially spurious results due to the presence of unit roots. The details of the Phillips-Perron tests are given in Appendix C.1. Further discussion on stationarity is presented in the sensitivity section of this chapter. The Durbin-Watson test and the Breusch-Godfrey test both indicate that there is first order autocorrelation (AR1) present in the model (the test results are provided in Appendix C. 2 and C.3 respectively). Consequently, the data were corrected using the Prais-Winsten technique. An examination of the residuals indicated no

\footnotetext{
${ }^{34}$ Some of the other independent variables that did not yield any statistically significant results and are therefore not included in the final results table (Table 4.1) are yearly GDP, GDP growth rate, oil prices, the exchange rate and the number of Pakistani migrants abroad (based on interpolation of occasional annual data). Complete monthly data for Pakistani migrant stock in each of the major destination countries were not available and the tests were done on estimates available for few sample years.
} 
compelling need to correct for heteroscedasticity. Table 4.1 below presents the results of the estimations for the two-time periods: January 1996 - December 2010 and January 2002

- December 2010. The lag lengths for the independent variables were determined using a trial and error method. Several lags were tested and the results presented in Table 4.1 are those that are associated with a statistically significant impact on remitting patterns.

Table 4.1: Main Estimation Results

\begin{tabular}{|c|c|c|}
\hline Variable $^{\dagger}$ & $\begin{array}{c}\text { January 1996-December } \\
2010 \\
\end{array}$ & $\begin{array}{c}\text { January 2002-December } \\
2010 \\
\end{array}$ \\
\hline & $\begin{array}{l}\text { Estimated Coefficient } \\
\text { (t-statistic in brackets) }\end{array}$ & $\begin{array}{l}\text { Estimated Coefficient } \\
\text { (t-statistic in brackets) }\end{array}$ \\
\hline $\begin{array}{l}\text { The number of people killed in disasters } \\
\text { (current month) }\end{array}$ & $\begin{array}{c}9665.70 * * \\
(9.13)\end{array}$ & $\begin{array}{c}9913.75 * * \\
(6.98)\end{array}$ \\
\hline $\begin{array}{l}\text { The number of people killed in disasters } \\
\text { (seven-month lag) }\end{array}$ & $\begin{array}{l}3881.76 * * * \\
(3.73)\end{array}$ & $\begin{array}{l}3932.82 * * * \\
(2.91)\end{array}$ \\
\hline $\begin{array}{l}\text { Number of terrorism-related fatalities } \\
\text { (current month) }\end{array}$ & $\begin{array}{c}-178061.4 \\
(-1.28)\end{array}$ & $\begin{array}{c}-333047.9 * \\
(-1.82)\end{array}$ \\
\hline Eid Festivities (current month) & $\begin{array}{c}37200000 * * * \\
(2.47)\end{array}$ & $\begin{array}{c}60000000 * * \\
(2.47)\end{array}$ \\
\hline Hajj (Islamic Pilgrimage) (current month) & $\begin{array}{c}30800000 * * \\
(1.98)\end{array}$ & $\begin{array}{l}62700000^{*} \\
(1.95)\end{array}$ \\
\hline Time trend (monthly) & $\begin{array}{c}408858 * * * \\
(11.97) \\
\end{array}$ & $\begin{array}{c}525950 * * * \\
(7.42)\end{array}$ \\
\hline Constant & $\begin{array}{c}-76100000 * * \\
(-2.21)\end{array}$ & $\begin{array}{c}-224000000 * * * \\
(-2.54)\end{array}$ \\
\hline Observations & 180 & 108 \\
\hline R-squared & 0.62 & 0.54 \\
\hline
\end{tabular}

$\dagger$ Dependent Variable: Total remittance inflows to Pakistan

$* * *, * *, *$, represent statistically significant at the $1 \%, 5 \%$ and $10 \%$ level respectively for two-tailed tests.

\subsubsection{Remittance Inflows Increase in the Aftermath of Natural Disasters}

Pakistan experienced 94 natural disasters including earthquakes, monsoon floods, cyclones and drought during the period 1996-2010 and 63 disasters during the period $2002-$ 2010.

The results in Table 4.1 indicate that Pakistani migrants living abroad remit significantly more in response to natural disasters affecting their home country. For the two periods examined here, for every fatality, migrants responded immediately (in the same month) by increasing the amount of remittances they sent home. Total monthly remittance 
inflows to Pakistan increased on average by US\$9,666 and US\$9,914 per fatality for the two study periods $1996-2010$ and 2002-2010 respectively. It is important to note that the increase in remittance amounts are not specifically received by households who lost a family member because of the disaster. This increase needs to be interpreted as a cumulative response by Pakistani migrants living abroad to disasters affecting their home country.

Lagged versions of this disaster fatality variables were also included in the model to see if there were any subsequent medium-term changes in remittances after a disaster. The results from these variables indicate that there was a temporary but significant increase in remittances seven months after a disaster. However, the magnitude of this subsequent response (US $\$ 3,882$ and US\$3,933 respectively) is less than the initial supplement. One of the reasons behind this increase could be that once migrants respond immediately after the disaster event (the same month), it might take them a while to gather more income (save money) to send "extra" remittances in additional to their regular remittance amounts.

Out of the 94 disasters that occurred in Pakistan during 1996-2010, there were five that resulted in more than 5,000 fatalities. To examine if remittances behaved differently in response to these five disasters, the estimation was run using severity thresholds. To test for a possible non-linear effect or different response during the more severe disasters, an additional variable was added to the estimating equation to represent fatalities in disasters with more than 5,000 fatalities. The coefficient estimate for this variable was not statistically significant, indicating that remittance responses were similar regardless of the severity of the disasters. In some versions of the equation the coefficient estimate was negative and approached acceptable levels of statistical significance, but the result was not very robust. So, while there is some evidence that the remittance response is slightly 
smaller per fatality for more severe disasters (suggesting either a non-linear response or perhaps an upper bound on migrants' capacity to remit) the evidence for this claim is considerably weaker.

\subsubsection{Responsiveness of Remittances to Terrorism-related Fatalities in Pakistan}

According to the results in Table 4.1, there is a weak statistical relationship between terrorism-related fatalities and the total remittance inflows into Pakistan: migrants remit less in response to terrorism-related fatalities. As can be seen in Table 4.1, although the absolute values indicate an inverse relationship, the statistical significance of the associated coefficient estimate only reaches marginally acceptable levels for the post-2001 sample. Lagged variables for terrorism-related fatalities did not yield any statistically significant coefficient estimates. Thus, for the two study periods, total remittance inflows into Pakistan appear largely non-responsive to terrorist events in the country, with weak evidence that remittances are actually deterred. Intuitively, this response may be understandable, as migrants may well be uncertain how to respond, may be concerned about the reliability of payment systems, and may be reluctant to invest (via remittances) in the presence of extreme political violence. In addition, the number of people affected, and the nature of the harm they incur, may not be comparable to more extensive natural disasters, as the immediate damage is often very localized.

It is important to note that the findings of this chapter are different from those put forward by Mughal and Anwar (2014), who find that remittances increase in the aftermath of terrorist events in Pakistan. There are three potential reasons for the differences in the findings. First, the data source used by Moghul and Anwar is not the same as this chapter. This chapter uses data from the Global Terrorism Dataset (GTD), whereas Mughal and Anwar combine the data from the GTD as well as the South Asia Terrorism Portal (SATP). 
The SATP dataset only contains data starting from January 2003. Consequently, Moghul and Anwar (2014) examine the period 2003-2011, whereas the time periods examined here are 1996-2010 and 2002-2010. Second, the terrorism-related fatality definition that SATP database uses is different from the GTD database: Moghul and Anwar uses the definition put forward by SATP. Finally, the estimation techniques and the variables included in the model are different.

\subsubsection{Responsiveness of Remittances to Major Religious Events in Pakistan}

The results presented in Table 4.1 also indicate that during the month of Eid, total remittance inflows to Pakistan significantly increase. For the period 1996-2010, the increase in remittances was approximately US\$37 million for the month of an Eid festival (Eid al-Fitr as well as Eid al-Adha), and during the period 2002-2010, the increase was approximately US $\$ 60$ million. Similarly, total remittances to Pakistan increased by US $\$ 31$ million (1996-2010) and US\$63 million (2002-2010) in the month of the Hajj (the annual pilgrimage to Mecca). The magnitude of the increase in remittances in response to these religious events can be understood by the fact that over 95 per cent of the population in Pakistan are Muslims, and these events are considered important from a religious as well as cultural perspective. These findings conform to the general expectation that migrants remit money for a variety of reasons and uses. Remittances to support religious and cultural activities at home may be an obligation for the migrants and an expectation by their family members, though of course the migrants themselves may view such payments as an investment in maintaining their status and connections within their family and community. Lastly, although the estimation coefficients for the Hajj variable indicate a statistically significant result, it is not as strong as the significance level observed for the Eid variable (1\% significance level). 


\subsection{Sensitivity Analysis}

A variety of sensitivity tests were conducted on the main estimations. For example, the estimation was done with the Cochrane-Orcutt correction for autocorrelation (as a substitute for the Prais-Winsten technique), and White's correction for robust standard errors in case of heteroscedasticity. In both cases the results are largely identical to those reported in Table 4.1. A version of the model with the log of the dependent variable (remittances) was also used, and again produced qualitatively similar results as before, with the only exception being that the Hajj variable no longer had a statistically significant coefficient estimate. All the versions of the standard regression model confirmed the main result that migrants increase their remittances in the aftermath of natural disasters.

In addition to the more standard regression techniques, further estimations were done to ensure that the time-series characteristics of the data were properly analyzed. As noted earlier, the Phillips-Perron tests indicated that the data are stationary. Another test for stationarity is the Dickey-Fuller test. The Philips-Perron test is similar to the DickeyFuller test but is corrected for autocorrelation and heteroskedasticity (Stata Guide version 12, n.d.). Another important advantage of the Philips-Perron test is that it is non-parametric (Phillips \& Perron, 1988).

The Dickey-Fuller test results for the series were less conclusive, at least for those models that included higher order lags. Consequently, an Autoregressive Distributed Lag (ARDL) model in levels was also estimated with a trend term included to test the robustness of the main claims of the chapter - remittances increase in the aftermath of natural disasters. In this model, none of the other explanatory variables had statistically significant coefficient estimates, and were excluded from the final estimation reported here. The results of the ARDL model are presented in Table 4.2. 
Table 4.2: ARDL Estimation Results

\begin{tabular}{|c|c|c|}
\hline Variable $^{\dagger}$ & $\begin{array}{c}\text { January 1996- } \\
\text { December } 2010\end{array}$ & January 2002-December 2010 \\
\hline & $\begin{array}{l}\text { Estimated Coefficient } \\
\text { (t-statistic in brackets) }\end{array}$ & $\begin{array}{l}\text { Estimated Coefficient } \\
\text { (t-statistic in brackets) }\end{array}$ \\
\hline Remittances detrended (one-month lag) & $\begin{array}{c}0.5713 * * * \\
(9.03)\end{array}$ & $\begin{array}{c}0.4339 * * * \\
(4.92)\end{array}$ \\
\hline $\begin{array}{l}\text { The number of people killed in disasters } \\
\text { (current month) }\end{array}$ & $\begin{array}{c}9206.21 * * * \\
(7.38)\end{array}$ & $\begin{array}{l}9055.55^{* * * *} \\
(5.98)\end{array}$ \\
\hline $\begin{array}{l}\text { The number of people killed in disasters } \\
\text { (one-month lag) }\end{array}$ & $\begin{array}{c}-7346.02 \\
(-1.67)\end{array}$ & $\begin{array}{c}-6101.44^{*} \\
(-1.82)\end{array}$ \\
\hline $\begin{array}{l}\text { The number of people killed in disasters } \\
\text { (seven-month lag) }\end{array}$ & $\begin{array}{l}3380.70 * * * \\
(2.71)\end{array}$ & $\begin{array}{l}3282.99 * * * \\
(3.17)\end{array}$ \\
\hline $\begin{array}{l}\text { Number of terrorism-related fatalities } \\
\text { (current month) }\end{array}$ & $\begin{array}{c}-123370.4 \\
(-1.12) \\
\end{array}$ & $\begin{array}{l}-87066 \\
(-0.59) \\
\end{array}$ \\
\hline Constant & $\begin{array}{l}1050000 \\
(1.20)\end{array}$ & $\begin{array}{l}1351436 \\
(0.09)\end{array}$ \\
\hline Observations & 180 & 108 \\
\hline R-squared & 0.44 & 0.35 \\
\hline
\end{tabular}

${ }^{\dagger}$ Dependent Variable: Detrended total remittance inflows to Pakistan

$* * *, * *, *$, represent statistically significant at the $1 \%, 5 \%$ and $10 \%$ level respectively for two-tailed tests.

According to the results of the ARDL model, the overall responsiveness of remittances to natural disasters behave in the similar manner as indicated by the results in Table 4.1. The ARDL results in Table 4.2 indicate that remittances increase immediately (in the same month) in response to natural disasters. This initial increase in remittances is partly reversed in the following month. However, this reversal affect is only marginally significant for the period 2002-2010. Similar to the results presented in Table 4.1, there is an increase in remittances after the seventh month following disasters. The results in Table 4.2 indicate that terrorism-related fatalities do not significantly influence remittance patterns for the two study periods.

In Appendix C.4, further ARDL estimations in levels and first differences are presented using the error-correction form to examine the long-run and short-run relationship. As can be seen in Appendix C.4, the F-statistics and the t-statistics indicate that there is no long-run relationship in levels between remittances and the explanatory variables, though there is in first differences. Given this result the initial OLS-based 
regression results seem the most suitable. While there is no long run relationship in levels, the revealed short-run relationship between remittances and each of the explanatory variables (except for the Hajj variable) reinforces the main results reported above. These different estimating approaches point to a consistent story that reflects the nature of the data. Fluctuations in the (de-trended) remittance variable respond on a short-term basis to the explanatory variables which exhibit an intermittent or occasional event pattern. Therefore, the scope for a long-term relationship between the dependent variable and the explanatory variables is quite limited.

Another test for stationarity included checking if the variables are cointegrated. The tests found no evidence of cointegration. Consequently, an ARDL model in first differences was run. The results indicate that the main claims of the chapter - remittances increase in the aftermath of natural disasters - hold true. The coefficient of all the disasterrelated variables had the same sign and significance level as those reported in Table 4.1 including the same effect of increase in remittances around seven months following the disaster. The only difference noted in this model compared to Table 4.1 , is in the significance level of the Hajj variable. Unlike Table 4.1, the results in this model indicate that the Hajj variable do not have a significant impact on determining remittance inflows to Pakistan.

Further checks were conducted to examine if there are problems arising from autoregression or a moving average. This possibility was examined by running an Autoregressive Integrated Moving Average (ARIMA) model. The results of the ARIMA model support the results reported in Table 4.1. The only exception is that under the ARIMA model, the effect of Hajj on remittance increases are not statistically significant. 
Therefore, it can be concluded that the main findings of the chapter which state that remittances increase in the aftermath of natural disasters remain strong. The impact of Eid is also found to be generally robust. Although the occurrence of Hajj leads to an increase in remittance inflows, the influence of this factor on remittance inflows is not as robust as the effect of the other variables (natural disasters and Eid). Further, similar to Table 4.1 results, all the models tested in this sensitivity section also conclude that terror-related fatalities do not significantly influence remittance patterns for the two study periods.

In relation to the natural disaster variables, as mentioned earlier, this chapter used only one of CRED's disaster-related variables (the number of people killed during the disaster) to measure the magnitude of the disaster as the other two variables did not include complete data for all disasters during the two study periods. Nonetheless, as a secondary check, the chapter also ran the same estimation as Table 4.1 using the disaster variable, "the total number of people affected by the disaster". The results using this variable indicate that for every person affected by disasters, migrants respond immediately (in the same month) by increasing the amount of remittances they sent home. Lagged versions of this disaster variable were also included in the model. None of the lagged variables was associated with statistically significant changes. The effect of the Eid variable is the same as indicated in Table 4.1. However, the Hajj variable does not yield any significant changes in remitting patterns.

\subsection{Conclusion}

Utilizing a monthly remittance dataset from the State Bank of Pakistan and monthly natural disasters data from the International Emergency Disasters Database (EM-DAT), this chapter is the first of its kind examining the responsiveness of remittances in the aftermath of natural disasters affecting Pakistan. The two periods examined in this chapter 
are 1996-2010 and 2002-2010. The latter period was separately examined to check if the main conclusions of the chapter remained the same between the periods 1996-2010 and 2002-2010 since the reported inflow of remittances from all the countries to Pakistan increased substantially after the increase in global anti-money laundering activities following the September 2001 terrorist events in the US.

The empirical results of this macro-level study indicate that Pakistani migrants remit significantly more in the aftermath of natural disasters affecting their country. The increased remittances are on average US $\$ 9,666$ to US $\$ 9,914$ per fatality. In addition, there also appears to be a subsequent increase in remittances around seven months following the disaster.

Along with the impact of natural disasters on remittance inflows, this chapter also investigated how remittance inflows are affected by other factors such as major religious events (Eid and Hajj) and terrorism-related fatalities. The findings reveal that in response to major religious events Pakistani migrants remit significantly more to their home country. Eid festivities and participation in Hajj attracted major inflows into Pakistan from all destination countries. In investigating the responsiveness of remittance inflows into Pakistan to terrorism-related fatalities the results indicate a presence of an inverse relationship, though this relationship is not robustly statistically significant.

The empirical results of this chapter support the existing theoretical expectations put forward by the NELM scholars. According to the NELM theorists, migration decisions are taken by the migrants in consultation with their households. Migration is viewed as a riskmitigation strategy employed by the households to diversify their income sources to smooth consumption during difficult financial times such as those following natural 
disasters. Remittances sent home ameliorate the adverse effects associated with natural disasters.

While the findings of this chapter sheds light onto responsiveness of remittances to various factors, it is important to note that these conclusions are based on macro-level responses (total remittance inflows to Pakistan) in the aftermath of natural disasters. Therefore, it tells the story of the average response of migrants as a group, rather than the response by each individual migrant. Finally, although the findings of this country-specific study provide insights to how some migrant groups behave in response to natural disasters, without further analysis it would be difficult to ascertain if the remitting patterns observed here can be extended to other countries. Given the importance of financial support in the aftermath of natural disasters, understanding how a country's diaspora responds to such events will provide a useful way of determining how other financial flows can be managed to provide more disaster relief in the fastest and most effective manner. 


\section{Appendix C}

\section{C.1 Phillipps-Perron Tests}

The following presents the Phillips-Perron test results for 1 lag and 12 lags for the study period 2002-2010. The null hypothesis is that there is a unit root. From the results, it can be concluded that the series is stationary with a trend since the test statistics always exceed the critical values even for the 1 per cent level of significance. The same conclusion can be drawn for all of the tests using lags between 1 and 12 for both study periods, with these two lags below being provided for illustration.

\section{Dependent Variable: Sum of remittances}

Phillips-Perron Test for Unit Root (Lag 1)

Number of Obs:108

Newey-West lags $=1$

\begin{tabular}{|c|c|c|c|c|}
\hline \multicolumn{5}{|c|}{ Interpolated Dickey-Fuller } \\
\hline & Test Statistic & 1\% Critical Value & $\begin{array}{l}5 \% \\
\text { Value }\end{array}$ & $10 \%$ Critical Value \\
\hline$Z$ (rho) & -32.338 & -19.827 & -13.716 & -11.011 \\
\hline$Z(\mathrm{t})$ & -4.453 & -3.507 & -2.889 & -2.579 \\
\hline
\end{tabular}

Phillips-Perron Test for Unit Root (Lag 12)

Number of Obs:108

Newey-West lags $=12$

\begin{tabular}{|c|c|c|c|c|}
\hline \multicolumn{5}{|c|}{$\longrightarrow$ Interpolated Dickey-Fuller } \\
\hline & Test Statistic & 1\% Critical Value & $\begin{array}{ll}5 \% & \text { Critical } \\
\text { Value } & \end{array}$ & $10 \%$ Critical Value \\
\hline$z$ (rho) & -57.360 & -19.827 & -13.716 & -11.011 \\
\hline$Z(\mathrm{t})$ & -5.655 & -3.507 & -2.889 & -2.579 \\
\hline
\end{tabular}




\section{Independent Variable: Number of people killed in disasters}

\begin{tabular}{|c|c|c|c|c|}
\hline \multicolumn{5}{|c|}{ Phillips-Perron Test for Unit Root (Lag 1) } \\
\hline & & & & $\begin{array}{l}\text { Number of Obs: } 108 \\
\text { Newey-West lags }=1\end{array}$ \\
\hline \multicolumn{5}{|c|}{$\longrightarrow$ Interpolated Dickey-Fuller $\longrightarrow$} \\
\hline & Test Statistic & 1\% Critical Value & $\begin{array}{ll}5 \% & \text { Critical } \\
\text { Value } & \\
\end{array}$ & $10 \%$ Critical Value \\
\hline$Z$ (rho) & -109.195 & -27.453 & -20.732 & -17.527 \\
\hline$Z(\mathrm{t})$ & -10.363 & -4.037 & -3.449 & -3.149 \\
\hline
\end{tabular}

Phillips-Perron Test for Unit Root (Lag 12)

Number of Obs:108

Newey-West lags $=12$

\begin{tabular}{|c|c|c|c|c|}
\hline \multicolumn{5}{|c|}{ Interpolated Dickey-Fuller } \\
\hline & Test Statistic & 1\% Critical Value & \begin{tabular}{|ll}
$5 \%$ & Critical \\
Value & \\
\end{tabular} & $10 \%$ Critical Value \\
\hline$Z$ (rho) & -103.361 & -27.453 & -13.716 & -11.011 \\
\hline$Z(\mathrm{t})$ & -10.379 & -4.507 & -3.449 & -3.149 \\
\hline
\end{tabular}

\section{Independent Variable: Terrorism-related fatalities}

$\underline{\text { Phillips-Perron Test for Unit Root (Lag 1) }}$

Number of Obs:108

Newey-West lags $=1$

\begin{tabular}{|c|c|c|c|c|}
\hline \multicolumn{5}{|c|}{$\longrightarrow$ Interpolated Dickey-Fuller } \\
\hline & Test Statistic & $1 \%$ Critical Value & $\begin{array}{ll}5 \% & \text { Critical } \\
\text { Value } & \end{array}$ & $10 \%$ Critical Value \\
\hline$Z$ (rho) & -89.034 & -27.453 & -20.732 & -17.527 \\
\hline$Z(\mathrm{t})$ & -8.737 & -4.037 & -3.449 & -3.149 \\
\hline
\end{tabular}

$\underline{\text { Phillips-Perron Test for Unit Root (Lag 12) }}$

Number of Obs:108

Newey-West lags $=12$

\begin{tabular}{|c|c|c|c|c|}
\hline \multirow{2}{*}{\multicolumn{5}{|c|}{$\begin{array}{l}\text { Newey-West lags }=1 \\
\text { Interpolated Dickey-Fuller }\end{array}$}} \\
\hline & & & & \\
\hline & Test Statistic & $1 \%$ Critical Value & $\begin{array}{ll}5 \% & \text { Critical } \\
\text { Value } & \end{array}$ & $10 \%$ Critical Value \\
\hline$Z$ (rho) & -122.638 & -27.453 & -20.732 & -17.527 \\
\hline$Z(\mathrm{t})$ & -9.360 & -4.037 & -3.449 & -3.149 \\
\hline
\end{tabular}




\section{Independent Variable: Eid}

\section{Phillips-Perron Test for Unit Root (Lag 1)}

Number of Obs:108 Newey-West lags $=1$

\begin{tabular}{|c|c|c|c|c|}
\hline \multicolumn{5}{|c|}{$\longrightarrow$ Interpolated Dickey-Fuller $\longrightarrow$} \\
\hline & Test Statistic & 1\% Critical Value & \begin{tabular}{ll|}
$\mathbf{5 \%}$ & Critical \\
Value & \\
\end{tabular} & $10 \%$ Critical Value \\
\hline$z$ (rho) & -118.378 & -27.453 & -20.732 & -17.527 \\
\hline$Z(\mathrm{t})$ & -11.360 & -4.037 & -3.449 & -3.149 \\
\hline
\end{tabular}

Phillips-Perron Test for Unit Root (Lag 12)

Number of Obs:108

Newey-West lags $=12$

\begin{tabular}{|c|c|c|c|c|}
\hline \multicolumn{5}{|c|}{$\longrightarrow$ Interpolated Dickey-Fuller } \\
\hline & Test Statistic & 1\% Critical Value & $\begin{array}{ll}\mathbf{5 \%} & \text { Critical } \\
\text { Value } & \\
\end{array}$ & $10 \%$ Critical Value \\
\hline$Z$ (rho) & -78.774 & -27.453 & -20.732 & -17.527 \\
\hline$z(\mathrm{t})$ & -15.023 & -4.037 & -3.449 & -3.149 \\
\hline
\end{tabular}

\section{Independent Variable: Hajj}

Phillips-Perron Test for Unit Root (Lag 1)

Number of Obs:108

Newey-West lags $=1$

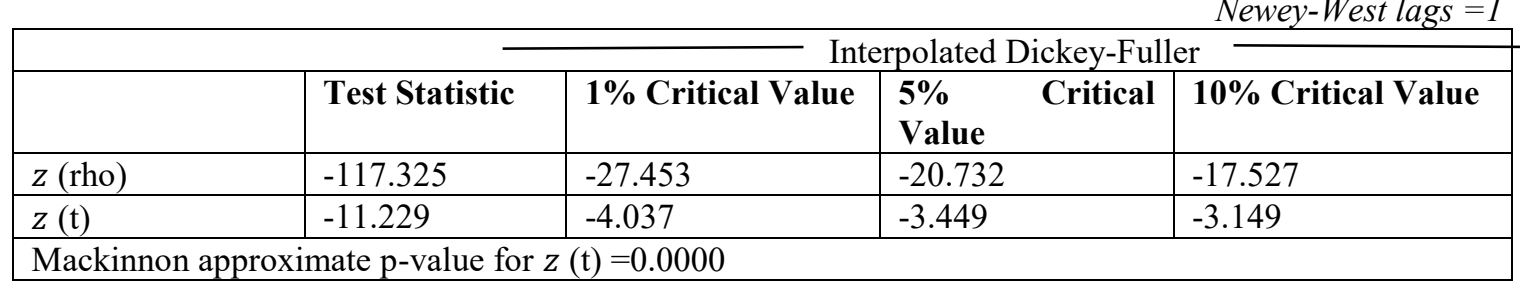

$\underline{\text { Phillips-Perron Test for Unit Root (Lag 12) }}$

Number of Obs:108

Newey-West lags $=12$

\begin{tabular}{|c|c|c|c|c|}
\hline \multicolumn{5}{|c|}{ Interpolated Dickey-Fuller } \\
\hline & Test Statistic & 1\% Critical Value & $\begin{array}{ll}\mathbf{5 \%} & \text { Critical } \\
\text { Value } & \end{array}$ & $10 \%$ Critical Value \\
\hline$z$ (rho) & -78.513 & -27.453 & -20.732 & -17.527 \\
\hline$z(\mathrm{t})$ & -14.398 & -4.037 & -3.449 & -3.149 \\
\hline
\end{tabular}




\section{C.2 Durbin-Watson Test}

For the period 1996-2010: the Durbin-Watson Test for the critical values for $\mathrm{k}=7$ and $n=173$ are $d_{L}=1.58$ and $d_{U}=1.72$ for the 1 per cent significance test. Similarly, for the period 2002-2010: the Durbin-Watson Test for the critical values for $\mathrm{k}=7$ and $\mathrm{n}=108$ are $\mathrm{d}_{\mathrm{L}}=1.45$ and $\mathrm{d}_{\mathrm{U}}=1.68$ for the 1 per cent significance test.

The Durbin-Watson statistics are 0.988 and 1.06 for the 1996-2010 and 2002-2010 periods respectively. These are both well below the $d_{L}$ critical values, so the null hypothesis of no autocorrelation is rejected for both sample periods and the alternative of positive autocorrelation is accepted. For the main results presented in Table 4.1, the transformed Durbin-Watson statistic for the estimation covering 1996-2010 is 2.12 and for 2002-2010 it is 2.04. Both numbers indicate that the autocorrelation has been corrected using the PraisWinsten transformation. 


\section{C.3 Breusch-Godfrey Test}

The following presents the Breusch-Godfrey tests for the two-time periods 19962010 and 2002-2010 examined in this chapter. The null hypothesis indicates no autocorrelation and the probability of accepting the null is given as 0.0000 .

\section{Breusch-Godfrey Test for Autocorrelation}

\begin{tabular}{|c|c|c|c|}
\hline Breusch-Godfrey LM test for autocorrelation (1996-2010) \\
\hline $\operatorname{lags}(\mathrm{p})$ & chi2 & df & Prob $>$ chi2 \\
\hline 1 & 41.436 & 1 & 0.0000 \\
\hline
\end{tabular}

H0: No serial correlation

Breusch-Godfrey LM test for autocorrelation (2002-2010)

\begin{tabular}{|c|c|c|c|}
\hline $\operatorname{lags}(\mathrm{p})$ & $\mathrm{chi} 2$ & $\mathrm{df}$ & Prob $>$ chi2 \\
\hline 1 & 21.147 & 1 & 0.0000 \\
\hline
\end{tabular}

H0: No serial correlation 


\section{C.4 ARDL Models Using Error-Correction}

ARDL in Levels Using Error-Correction Model

\begin{tabular}{|c|c|c|c|}
\hline & & $\begin{array}{c}\text { January 1996-December } \\
2010\end{array}$ & $\begin{array}{c}\text { January 1996-December } \\
2010\end{array}$ \\
\hline & Variable & $\begin{array}{c}\text { Estimated Coefficient } \\
\text { (t-statistic in brackets) }\end{array}$ & $\begin{array}{c}\text { Estimated Coefficient } \\
\text { (t-statistic in brackets) }\end{array}$ \\
\hline ADJ & $\begin{array}{c}\text { Remittances (one-month } \\
\text { lag) }\end{array}$ & $\begin{array}{r}-0.0332 \\
(-1.03) \\
\end{array}$ & $\begin{array}{r}-0.1099 \\
(-1.60) \\
\end{array}$ \\
\hline \multirow[t]{3}{*}{ LR } & Eid & $\begin{array}{l}2650000000 \\
(0.99)\end{array}$ & $\begin{array}{l}1690000000 \\
(1.51)\end{array}$ \\
\hline & Hajj & $\begin{array}{c}184000000 \\
(0.23)\end{array}$ & $\begin{array}{c}414000000 \\
(0.12)\end{array}$ \\
\hline & $\begin{array}{c}\text { Number of people killed in } \\
\text { disasters }\end{array}$ & $\begin{array}{c}13491.12 \\
(0.89)\end{array}$ & $\begin{array}{c}31173.75 \\
(0.67)\end{array}$ \\
\hline \multirow[t]{7}{*}{ SR } & $\begin{array}{c}\text { Remittances (one-month } \\
\text { lag) }\end{array}$ & $\begin{array}{c}0.4062915 * * * \\
(5.59)\end{array}$ & $\begin{array}{c}0.3498 * * * \\
(3.39) \\
\end{array}$ \\
\hline & Eid & $\begin{array}{c}79000000 * * * \\
(3.61)\end{array}$ & $\begin{array}{c}89000000 * * * \\
(3.56)\end{array}$ \\
\hline & Hajj & $\begin{array}{c}6882755 \\
(0.26)\end{array}$ & $\begin{array}{l}4835694 \\
(0.12)\end{array}$ \\
\hline & $\begin{array}{c}\text { Number of people killed in } \\
\text { disasters } \\
\text { (current month) }\end{array}$ & $\begin{array}{l}8858.221 * * * \\
(6.95)\end{array}$ & $\begin{array}{c}8099.13 * * * \\
(5.02)\end{array}$ \\
\hline & $\begin{array}{c}\text { Number of people killed in } \\
\text { disasters } \\
\text { (seven- month lag) }\end{array}$ & $\begin{array}{c}4435.576^{* * *} \\
(3.58)\end{array}$ & $\begin{array}{c}4276.25 * * * \\
(2.89)\end{array}$ \\
\hline & Constant & $\begin{array}{c}6987528 \\
(0.56)\end{array}$ & $\begin{array}{c}4277526 \\
(1.39) \\
\end{array}$ \\
\hline & R-squared & 0.59 & 0.56 \\
\hline
\end{tabular}

$* * *, * *, *$, represent statistically significant at the $1 \%, 5 \%$ and $10 \%$ level respectively for two-tailed tests.

Pesaran/Shin/Smith (2001) ARDL Bounds Test H0: no levels relationship

\begin{tabular}{|c|c|}
\hline For $1996-2010$ & For 2002-2010 \\
\hline $\mathrm{F}=4.068, \mathrm{t}=-1.107$ & $\mathrm{~F}=3.702, \mathrm{t}=-1.714$ \\
\hline
\end{tabular}


ARDL in First Differences Using Error-Correction Model

\begin{tabular}{|c|c|c|c|}
\hline & & $\begin{array}{c}\text { January 1996-December } \\
2010 \\
\end{array}$ & $\begin{array}{c}\text { January 1996-December } \\
2010 \\
\end{array}$ \\
\hline & Variable & $\begin{array}{l}\text { Estimated Coefficient } \\
\text { (t-statistic in brackets) }\end{array}$ & $\begin{array}{l}\text { Estimated Coefficient } \\
\text { (t-statistic in brackets) }\end{array}$ \\
\hline ADJ & $\begin{array}{c}\text { Remittances } \\
\text { (one-month lag) }\end{array}$ & $\begin{array}{l}-1.969666 * * * \\
(-8.03)\end{array}$ & $\begin{array}{c}-1.937904 * * * \\
(-8.27)\end{array}$ \\
\hline \multirow[t]{3}{*}{ LR } & Eid & $\begin{array}{c}27500000^{* * * *} \\
(3.21) \\
\end{array}$ & $\begin{array}{c}38200000 * * * \\
(2.96)\end{array}$ \\
\hline & Hajj & $\begin{array}{l}8055205 \\
(0.23) \\
\end{array}$ & $\begin{array}{c}16300000 \\
(0.12)\end{array}$ \\
\hline & $\begin{array}{l}\text { Number of people killed in } \\
\text { disasters }\end{array}$ & $\begin{array}{c}4860.735 \\
(0.85)\end{array}$ & $\begin{array}{c}4784.515 \\
(0.66)\end{array}$ \\
\hline \multirow[t]{7}{*}{$\begin{array}{l}\text { SR } \\
\end{array}$} & $\begin{array}{c}\text { Remittances (one-month } \\
\text { lag) }\end{array}$ & $\begin{array}{c}.554871 * * * \\
(4.59)\end{array}$ & $\begin{array}{c}.547951 * * * \\
-3.29) \\
\end{array}$ \\
\hline & Eid & $\begin{array}{c}54100000^{* * * *} \\
(3.17) \\
\end{array}$ & $\begin{array}{c}74000000^{* * *} \\
(3.70) \\
\end{array}$ \\
\hline & Hajj & $\begin{array}{c}5900000 \\
(0.90)\end{array}$ & $\begin{array}{c}31500000 \\
(1.11)\end{array}$ \\
\hline & $\begin{array}{c}\text { Number of people killed in } \\
\text { disasters } \\
\text { (current month) }\end{array}$ & $\begin{array}{c}8359.074 * * * \\
(6.82)\end{array}$ & $\begin{array}{l}8146.084^{* * *} \\
\quad(5.28)\end{array}$ \\
\hline & $\begin{array}{l}\text { Number of people killed in } \\
\text { disasters } \\
\text { (seven- month lag) }\end{array}$ & $\begin{array}{l}246.4473^{* * *} \\
\quad(2.98)\end{array}$ & $\begin{array}{l}379.7765 * * * \\
\quad(3.50)\end{array}$ \\
\hline & Constant & $\begin{array}{c}8194367 \\
(1.19)\end{array}$ & $\begin{array}{c}10700000 \\
(0.99)\end{array}$ \\
\hline & R-squared & 0.84 & 0.84 \\
\hline
\end{tabular}

Pesaran/Shin/Smith (2001) ARDL Bounds Test

H0: no levels relationship

$\mathrm{F}=36.331, \mathrm{t}=-10.767$

For 2002-2010

$\mathrm{F}=22.901, \mathrm{t}=-8.271$ 


\section{References}

Adams, R. H., \& Page, J. (2005). Do International Migration and Remittances Reduce Poverty in Developing Countries. World Development, 33(10), 1645-1669. https://doi.org/10.1016/j.worlddev.2005.05.004

Agarwal, R. \& Horowitz, A. W. (2002). Are international remittances altruism or insurance? Evidence from Guyana using multiple-migrant households. World Development, 30(11), 2033-2044. https://doi.org/10.1016/S0305-750X(02)001183

Amjad, R. \& Arif, G. M. (2014). Analyzing the impact of overseas migration and workers' remittances in Khyber Pakhtunkhaw. Working Paper F-37108-PAK-1. Retrieved from https://www.theigc.org/wp-content/uploads/2014/09/Amjad-Arif2014-Working-Paper.pdf

Anghel, R. G., \& Horvath, I. (2009). Sociologia Migraţiei. Teori Teorii şi studii de caz româneşti. Retrieved from http://www.academia.edu/1029015/Sociologia_Migra\%C5\%A3iei._Teorii_\%C5 \%9Fi_Studii_de_Caz_Rom\%C3\%A2ne\%C5\%9Fti

Asian Development Bank [ADB] (2012). Global Crisis, Remittances, and Poverty in Asia. Retrieved from https://think-asia.org/bitstream/handle/11540/102/globalcrisis-in-asia.pdf? sequence $=1$

Badie, B., \& Withol de Wenden, C. (1993). Le defi migratoire - questions de relations internationales. Politique étrangère,59(4), 1157-1159. Retrieved from http://www.persee.fr/doc/polit_0032342x_1994_num_59_4_4348_t1_1157_0000_2 
Carling, J. (2008). The determinants of Migrant Remittances. Oxford Review of Economic Policy, 3(1), 582-599. doi: https://doi.org/10.1093/oxrep/grn022

Cerón Monroy, H. (2004). "El rol del empleo no agropecuario como estrategia de ingreso en la reduccion de la pobreza en El Sector Rural De México." Paper presented at the seminar-workshop, Migracion, proreza y estructura de la economia rural Mexicana, PRESCESAM and REAP, 20-21 September, El Colegio de Mexico.

EM-DAT: The OFDA/CRED International Disaster Database, Université Catholique de Louvain, Brussels, Belgium. (Available at: www.em-dat.net)

EM-DAT: Glossary of Terms. Retrieved from https://www.emdat.be/Glossary

Gioli, G., Khan, T. \& Scheffran, J. (2013). Remittances and Community Resilience to Conflict and Environment Hazards in North Western Pakistan. Remittance Flows to PostConflict States: Perspectives on Human Security and Development.

Retrieved from https://www.researchgate.net/publication/272622898_Remittances_and_Commun ity_Resilience_to_Conflict_and_Environmental_Hazards_in_Northwestern_Pakis $\tan$

Global Terrorism Database. (2015). Retrieved on March 19, 2015 from https://www.start.umd.edu/gtd/

Glytsos, N. P. (1988). Remittances in Temporary Migration: A Theoretical Model and its Testing with the Greek-German Experience. Review of World Economics, 124(3), 524-49. doi:10.1007/BF02708664

Glytsos, N. P. (2002). The Role of Migrant Remittances in Development: Evidence from Mediterranean Countries. International Migration, 40(1), 5-26. doi: $10.1111 / 1468-2435.00183$ 
Gubert, F. (2002). Do migrants insure those who stay behind? Evidence from the Kayes Area (Western Mali). Oxford Development Studies, 30(2), 267-287. http://dx.doi.org/10.1080/1360081022000012699

History of Hajj. (2017). In Ministry of Hajj, History of Hajj. Retrieved on May 25, 2017 from http://www.hajinformation.com/main/f01.htm

International Federation of Red Cross and Red Crescent Societies. (2014). International Disaster Response Law in Pakistan. Retrieved from http://www.alnap.org/resource/21450

Irfan, M (2011). Remittances and Poverty Linkages in Pakistan: Evidence and some suggestions for further Analysis. Pakistan Institute of Development Economics, 78, 1-18.Retrieved from http://www.pide.org.pk/pdf/Working\%20Paper/WorkingPaper-78.pdf

Jamal, H. (2004). Remittances Inflows, Growth and Poverty: The Case of Pakistan. In Hisaya Oda (Ed.) International Labour Migration from South Asia. Tokyo: Institute of Developing Economics, Japan, External Trade Organisation.

Johnson, G. \& Whitelaw, W.E. (1974). Urban-Rural Income Transfers in Kenya: An Estimated-Remittances Function. Economic Development and Cultural Change, 22(3), 473-479. Retrieved from http://www.jstor.org/stable/1152632

Jongawanich, J. (2007). Workers Remittances, Economic Growth and Poverty in Developing Asia and the Pacific Countries. UNESCAPE Working Paper WP/07/01. Retrieved from http://www.unescap.org/sites/default/files/wp-0701.pdf

Kalim, R. \& Shahbaz, M. (2008). Remittances and Poverty Nexus: Evidence from Pakistan. International Research Journal of Finance and Economics, 29, 1450- 
2887. Retrieved from

https://www.researchgate.net/publication/228747567_Remittances_and_poverty_ nexus_Evidence_from_Pakistan

Katz, E. \& Stark, O. (1986). Labor Migration and Risk Aversion in Less Developed Countries. Journal of Labor Economics, 4(1), 134-149. Retrieved from http://www.jstor.org/stable/2534880

Kock, U. \& Sun, Y. (2011). Remittances in Pakistan - Why have they gone up, and why aren't they coming down? International Monetary Fund Working Paper 11/200. Retrieved from https://www.imf.org/en/Publications/WP/Issues/2016/12/31/Remittances-inPakistan-Why-have-they-gone-up-and-why-Aren-t-they-coming-down-25172

Lucas, R., \& Stark, O. (1985). Motivations to remit: evidence from Botswana. Journal of Political Economy, 93(5), 901-918. Retrieved from http://www.jstor.org/stable/1833062

Mamattah, S. (2006). Migration and transnationalism: the complete picture? A case study of Russians living in Scotland. eSharp, 6(2), 1-22. Retrieved from http://www.gla.ac.uk/media/media_41186_en.pdf Mascarenhas, R. \& Sandler, T. (2013). Remittances and Terrorism: A Global Analysis. Defence and Peace Economics, 25(4), 331-347. Retrieved from http://dx.doi.org/10.1080/10242694.2013.824676

Mughal, M. H \& Anwar, A. M. (2014). Do Migrants Remittances React to Bouts of Terrorism? Defence and Peace Economics, 26(6), 567-582.Retrieved from http://dx.doi.org/10.1080/10242694.2014.921359 
Noy, I. (2008). The Macroeconomic Consequences of Disasters. Journal of Development Economics, 88(2), 221-231. Retrieved from ttp://www.sciencedirect.com/science/article/pii/S0304-3878(08)00031-X

Phillips, P.C.B \& Perron, P. (1988). Testing for a unit root in time series regression. Biometrika, 75 (2), 335-46. Retrieved from jstore on September 14, 2017 https://www.jstor.org/stable/23361

Porumbescu, A. (2015). Defining the New Economics of Labour Migration Theory Boundaries: A Sociological-Level Analysis of International Migration. Retrieved from http://cis01.central.ucv.ro/revistadestiintepolitice/files/numarul45_2015/6.\%20De fining $\% 20 \mathrm{t}$

Qayyum, A., Javid, M. \& Arif, U. (2008). Impact of Remittances on Economic Growth and Poverty: Evidence from Pakistan. Pakistan Institute of Development Economics. Retrieved from https://mpra.ub.unimuenchen.de/22941/1/MPRA_paper_22941.pdf

Qureshi, J.A. (2016). The Pakistan Remittance Initiative and Remittance Flows to Pakistan. International Food Policy and Research Institute. Retrieved from http://www.ifpri.org/publication/pakistan-remittance-initiative-and-remittanceflows-pakistan

Suleri, A., \& Savage, K. (2006). Remittances in Crisis: A Case Study of Pakistan. Retrieved from https://www.odi.org/sites/odi.org.uk/files/odi-assets/publicationsopinion-files/385.pdf 
Stark, O. \& Bloom, D. (1985). The New Economics of Labor Migration. The American Economic Review, 75(2), 173-178. Retrieved from http://www.jstor.org/stable/1805591

Stata Guide version 12 (n.d.). Retrieved on September 14, 2017 from http://www.stata.com

State Bank of Pakistan. (2016). Retrieved on January 5, 2016 from http://www.sbp.org.pk/ecodata/index2.asp

Ullah, I., Rahman M. U. Jebran K., \& Zeb, A. (2015). Terrorism and Worker's Remittances in Pakistan. Journal of Business Studies Quarterly, 6(3), 178-189. Retrieved from http://jbsq.org/wp-content/uploads/2015/03/March_2015_12.pdf

Vertovec, S. (2001). Transnationalism and Identity. Journal of Ethnic and Migration Studies, 27(4), 573-582. doi:10.1080/13691830120090386

World Atlas (n.d.). Countries with the Largest Muslim Population in the World. Retrieved on May 16, 2017 from http://www.worldatlas.com/articles/countrieswith-the-largest-muslim-populations.html

The World Bank. (2006). Global Economic Prospects 2006: Economic Implications of Remittances and Migration. Retrieved from http://pubdocs.worldbank.org/en/346121443469727614/Global-EconomicProspects-2006-Economic-implications-of-remittances-and-migration.pdf

The World Bank Open Data.(2016). Retrieved on December 5, 2016 from http://data.worldbank.org/

Wu, T. (2006). The Role of Remittances in Crisis. An Aceh Research Study. Retrieved from https://www.odi.org/sites/odi.org.uk/files/odi-assets/publications-opinionfiles/408.pdf 
Zafar I, \& Sattar, A. (2005). The Contribution of Workers Remittances to Economic Growth in Pakistan. Pakistan Institute of Development Economics, Islamabad. Retrieved from http://www.pide.org.pk/Research/Report187.pdf 


\section{Chapter 5: Conclusion}

This thesis is motivated by two emerging trends. First, there is a strong consensus that remittances have become a reliable and resilient source of international finance for many developing countries. Second, there is now little debate that parts of the earth are becoming less habitable due to factors such as climate change, deterioration of agricultural lands, desertification, and water pollution (IPCC, 2007). The intensification of natural disasters - both sudden and slow-onset - are a major concern in developing countries due to their lower degree of resilience to shocks (Cuaresma, 2010; Kahn, 2005; Noy, 2009). Particular areas - including the Asian megadeltas - have been identified as 'hotspots' where greater exposure and sensitivity to climate change combined with limited adaptive capacity suggest that the impacts will be most significant (IOM, 2010). Climate change has intensified the current vulnerabilities that make it difficult for people to survive where they are. Consequently, international migration (and the associated remittances) has become an increasingly common coping mechanism adopted by people confronting natural disasters (Hugo, 1996).

Although in recent times, scholars and policy makers have started to examine the nexus between migration, climate change and its impact, there is a significant dearth in the literature when it comes to understanding how migrants living abroad respond to natural disasters affecting their homes. Using three distinct datasets focusing on different countries, particularly those located in the Asian megadeltas, this dissertation explores the question: "Do migrants remit more in the aftermath of natural disasters affecting their countries of origin?" 
The theoretical framework used in this paper is rooted in the New Economics of Labour Migration theory that views migration as a critical risk-mitigation strategy in the face of natural disasters. Migration is viewed as an investment and remittances are labelled as a return on that investment. Rooted in this theoretical framework is the claim that the decision to migrate is a household decision and migrants send remittances to secure and smooth their families' consumption in a context of missing or imperfect financial and insurance markets (Gubert, 2002).

Results of the three essays find compelling evidence to support the assertions by the NELM theorists that in times of distress faced by migrants left-behind households (as a result of natural disasters), migrants respond by increasing their remittances. Therefore, the study provides evidence that remittance earnings are indeed an important source of income that household rely on (their income diversification strategy) to reduce adverse impacts from unfavourable events, such as natural disasters.

Chapter 2 of this dissertation makes a unique contribution to the remittance literature, particularly to the Canadian remittance literature, by examining the responsiveness of remittances sent by recent Canadian immigrants in the aftermath of natural disasters affecting their countries of origin. The empirical results of this study indicate that recent immigrants to Canada remit significantly more in the aftermath of natural disasters affecting their home countries. The other findings of the research exploring the impact of migrants' characteristics on remitting decisions conformed well to the existing theoretical expectations. For instance, the results indicate that there is a strong positive relationship between migrants' income and the amount they remit. Similarly, the amount of remittances sent home is inversely related to the number of household members the migrant has with them in Canada. 
There is no consensus in the migration literature when it comes to understanding the influence of migrants' sex on remitting patterns. This study found that among recent Canadian immigrants, male remit significantly more than their female counterparts and that marital status does not play a crucial role in influencing remitting patterns. It is important to interpret these empirical findings with caution as it does not take into consideration complex social factors, such as the underlying gender dynamics within the migrants' households, which may tell us a more nuanced narrative. Other interesting findings of this study include an understanding about the influence of a migrant's immigration category on their remitting patterns. For instance, compared to immigrants who entered Canada as skilled workers, provincial nominees or independent immigrants, refugees remitted significantly less. This result aligns with the anecdotal evidence that refugees often come to Canada with fewer financial resources and are often escaping serious and adverse political conditions in their countries of origin. Against this context, it may be interpreted that refugees do not have adequate financial capacity to remit within the first several years of their arrival compared to the other groups of immigrants.

Using primary data collected through 118 in-depth field interviews with migrant workers from two villages in Bangladesh located near the southwest border to India, Chapter 3 applies both quantitative as well as qualitative methods to examine how migrants and their families use migration and remittances as a coping mechanism in the face of frequent flooding. These findings shed light onto the gendered nature of migration by exploring the varying remitting patterns of female and male migrants in response to natural disasters affecting their homes in Bangladesh. While men tend to send more money home, they also tend to earn more as migrants. By contrast women remit a larger share of their income generally, and send almost all their residual income in the event of a natural 
disaster. Another crucial finding of the study is that given the proximity between Bangladesh and India (neighbouring countries), in the aftermath of natural disasters approximately 45 per cent of the migrants returned home temporarily to rejoin their affected households. Returning home with savings and sending remittances are interrelated behaviours that characterize ways of accomplishing the same outcome: repatriating earnings to the home (Durand, Kandel, Parrado, \& Massey, 1996). There is a lack of discussion in the existing migration and remittance literature when it comes to analyzing these intricate aspects of remitting behaviour.

Finally, using aggregate monthly remittances for the two-time periods: 1996-2010 and 2002-2010, Chapter 4 examines the responsiveness of total remittances into Pakistan in the aftermath of natural disasters. The empirical results of this macro-level study indicate that Pakistani migrants remit significantly more in the aftermath of natural disasters affecting their country. The increased remittances are on average US\$9,666 and US\$9,914 per fatality for the two-time periods examined. In addition, there also appears to be a subsequent increase in remittances around seven months following the disaster. This chapter also investigates other factors such as influence of major religious events and the occurrence of terrorism-related fatalities in the country. The findings reveal that in response to major religious events, Pakistani migrants remit significantly more to their home country. Remittance inflows appear largely non-responsive to terrorist events in the country, with weak evidence that remittances are actually deterred in the aftermath of these events.

Despite the different datasets, levels of analysis, countries and time periods, all three chapters find strong and robust evidence of a significant increase in remittances in response to natural disasters in the home community. These results are also consistent with 
the NELM framework, and indeed arguably provides compelling evidence of the important risk mitigation role of migration and the associated remittances that NELM theory predicts. Natural disasters can be one of the most extreme sources of risk faced by many vulnerable households, and the compensatory response of remittances is an important mechanism for disaster relief.

In a period where the world continues to encounter severe weather-related disasters, the influence of environment on migration and its associated remittances is a crucial discussion. There are also several policy implications associated with the increase in remittances in response to natural disasters. For instance, countries of origin government would need to be cognizant about how remittances impact emergency and recovery efforts following a disaster. Remittance-recipient households might recover faster than nonremittance recipient households. In the absence of proper disaster-management policies in place, there might be unwanted redistribution of resources among remittance recipient and non-recipient households exacerbating existing inequalities. Research findings by Le De, Gaillard and Friesen (2015) indicate that within a disaster context, remittances tend to increase or at least reproduce both the inequalities and vulnerabilities existing within the countries of origin. As a result, it is important to emphasize that while migrants can often respond faster, remittances are not a substitute for government assistance or external aid during disasters. Government's would still need to take active steps to ensure that its affected population are recovering effectively and that the affected area is being restored.

This thesis attempts to contribute to the discussion of migration, remittances and natural disasters while fully acknowledging that there are other factors (e.g. human security) that contribute to the complexity of people's livelihood strategies and migration decisions. 


\section{References}

Cuaresma, J. (2010). Natural Disasters and Human Capital Accumulation, The World Bank Economic Review, 24 (2), 280-302. doi:10.1093/wber/lhq008

Durand, J., Kandel, W., Parrado, E.A., \& Massey, D.S. (1996). International migration and Development in Mexican Communities. Demography, 33(2), 249-264. Retrieved from http://www.jstor.org/stable/2061875

Gubert, F. (2002). Do migrants insure those who stay behind? Evidence from the Kayes Area (Western Mali). Oxford Development Studies, 30(2), 267-287. http://dx.doi.org/10.1080/1360081022000012699

Hugo, G. (1996). Environmental Concerns and International Migration. The international Migration Review, 30(1), 105-131. doi: 10.2307/2547462

Intergovernmental Panel on Climate Change [IPCC]. (2007). Contribution of Working Group II to the Fourth Assessment Report of the Intergovernmental Panel on Climate Change. In M. Parry, O. Canziani, J. Palutikof, P. van der Linden, C. Hanson (Eds.), Climate Change 2007: Impacts, Adaptation and Vulnerability (pp.28-65). Cambridge University Press: Cambridge, UK

International Organization for Migration [IOM]. (2010). Assessing the Evidence: Environment, Climate Change and Migration in Bangladesh. http://publications.iom.int/system/files/pdf/environment_climate_change_bangla desh.pdf

Kahn, M. E. (2005) The Death Toll from Natural Disasters: The Role of Income, Geography, and Institutions. The Review of Economics and Statistics, 87 (2), 271284. doi: 10.1162/0034653053970339 
Le De, L., Gaillard, J.C. \& Friesen W. (2015) Remittances and disaster: Policy implications for disaster risk management, Migration, Environment and Climate Change, 2(1). Retrieved from http://reliefweb.int/sites/reliefweb.int/files/resources/Policy_Brief_Series_Issue2

Noy, I. (2009). The Macroeconomic Consequences of Disasters, Journal of Development Economics, 88 (2), 221 - 231. doi:10.1.1.366.4565\&rep=rep1 